\title{
Over structurering van beoordelingsmethoden voor open vragen
}

Citation for published version (APA):

Frijns, P. H. A. M. (1993). Over structurering van beoordelingsmethoden voor open vragen. [Doctoral Thesis, Maastricht University]. Rijksuniversiteit Limburg. https://doi.org/10.26481/dis.19930304pf

Document status and date:

Published: 01/01/1993

DOI:

10.26481/dis.19930304pf

Document Version:

Publisher's PDF, also known as Version of record

\section{Please check the document version of this publication:}

- A submitted manuscript is the version of the article upon submission and before peer-review. There can be important differences between the submitted version and the official published version of record.

People interested in the research are advised to contact the author for the final version of the publication, or visit the DOI to the publisher's website.

- The final author version and the galley proof are versions of the publication after peer review.

- The final published version features the final layout of the paper including the volume, issue and page numbers.

Link to publication

\footnotetext{
General rights rights.

- You may freely distribute the URL identifying the publication in the public portal. please follow below link for the End User Agreement:

www.umlib.nl/taverne-license

Take down policy

If you believe that this document breaches copyright please contact us at:

repository@maastrichtuniversity.nl

providing details and we will investigate your claim.
}

Copyright and moral rights for the publications made accessible in the public portal are retained by the authors and/or other copyright owners and it is a condition of accessing publications that users recognise and abide by the legal requirements associated with these

- Users may download and print one copy of any publication from the public portal for the purpose of private study or research.

- You may not further distribute the material or use it for any profit-making activity or commercial gain

If the publication is distributed under the terms of Article $25 \mathrm{fa}$ of the Dutch Copyright Act, indicated by the "Taverne" license above, 


\title{
OVER STRUCTURERING
}

\section{VAN BEOORDELINGSMETHODEN \\ VOOR OPEN VRAGEN}

\author{
PROEFSCHRIFT \\ ter verkrijging van de graad van doctor \\ aan de Rijksuniversiteit Limburg te Maastricht, \\ op gezag van de Rector Magnificus, Prof. mr. M.J. Cohen, \\ volgens het besluit van het College van Dekanen, \\ in het openbaar te verdedigen \\ op donderdag 4 maart 1993 om 16.00 uur \\ door \\ Petrus Hubertus Anna Maria Frijns \\ geboren op 23 mei 1965 te 's-Gravenhage
}


Promotor:

Prof. dr. W.H.F.W. Wijnen

Co-promotor: $\quad$ Dr. C.P.M. van der Vleuten

Beoordelingscommissie: Prof. dr. M.J. Drop (voorzitter)

Dr. H.J.M. van Berkel

Prof. dr. W.M.G. Jochems (Technische Universiteit Delft)

Prof. dr. J.A. Knottnerus

Prof. dr. J.C.M. Metz (Katholieke Universiteit Nijmegen) 
Al onze wetenschap - die van het verleden, van het heden en van de toekomst - is niets vergeleken bij hetgeen we nooit zullen weten. Dat is niet erg. Dat is schitterend. Wanneer het onbereikbare oneindig is, dan heeft wetenschap zelf ook hoop op oneindigheid.

Konstantin Tsiolkofski (1857-1935) 


\section{INHOUDSOPGAVE}

Context van het onderzoek

Hoofdstuk 1: Schriftelijke simulatie-instrumenten voor het meten van vaardigheid in medisch probleemoplossen

1.1 Inleiding 3

1.2 Schriftelijke simulatie-instrumenten: een overzicht 3

1.3 Scoring van schriftelijke simulatie-instrumenten 5

1.3.1 Scoren aan de hand van categorieën 5

1.3.2 Aggregate scoring 7

1.3.3 Overige scoringsmethoden 7

1.4 Betrouwbaarheid van schriftelijke simulatie-instrumenten $\quad 8$

1.4.1 Interbeoordelaarsbetrouwbaarheid $\quad 8$

1.4.2 Intercasebetrouwbaarheid 8

$1.5 \quad$ Validiteit van schriftelijke simulatie-instrumenten 9

1.5.1 Construct validiteit 9

$\begin{array}{lll}1.5 .2 & \text { Concurrent validiteit } & 10\end{array}$

1.5.3 Predictieve validiteit 11

$1.6 \quad$ Recente ontwikkelingen op het gebied van instrumenten $\quad 12$ voor het meten van vaardigheid in medisch probleemoplossen

Hoofdstuk 2: Beoordelingsproblemen bij open vraagvormen

$\begin{array}{lll}2.1 & \text { Inleiding } & 15\end{array}$

$2.2 \quad$ Empirisch onderzoek naar beoordelaarseffecten 15

2.2.1 Invloed van handschriftkwaliteit en tekstkenmerken 15

$\begin{array}{ll}2.2 .2 & \text { Invloed van verwachtingspatronen }\end{array}$

$\begin{array}{lll}2.2 .3 & \text { Invloed van voorafgaande beoordelingen } & 16\end{array}$

$\begin{array}{lll}2.3 & \text { Beoordelingsmethoden voor open vraagvormen } & 17\end{array}$

Hoofdstuk 3: Vraagstellingen en onderzoeksopzet

3.1 Inleiding 21

3.2 Plaatsbepaling van het onderzoek 21

3.3 Vraagstellingen van het onderzoek 23

3.4 Methoden voor het schatten van de betrouwbaarheid 25

3.4.1 Klassieke testheorie 26

3.4.2 Generaliseerbaarheidstheorie 28

3.4.2.1 Generaliseerbaarheidsstudie 29

3.4.2.2 Decision-studie 29

3.4.3 Item-respons theorie 31 
3.4.4 De keuze van een benaderingswijze voor het schatten 36 van betrouwbaarheid

$3.5 \quad$ Operationalisering van de vraagstelling 37

3.6 Verwachtingen 38

$\begin{array}{lll}3.6 .1 & \text { Validiteit } & 38\end{array}$

3.6.2 Generaliseerbaarheidsanalyses 38

3.6.3 Weging 40

3.6.4 Waardering van de beoordelingsmethoden 41

3.7 Hypothesen 41

Hoofdstuk 4: Het pilot-onderzoek

$4.1 \quad$ Inleiding $\quad 43$

4.2 Vraagstellingen 43

4.3 Methode 45

4.3.1 Materialen $\quad 45$

4.3.1.1 Casus 45

4.3.1.2 Beoordelingsmethoden 46

$\begin{array}{lll}\text { 4.3.1.3 Vragenlijst } & 47\end{array}$

$\begin{array}{lll}4.3 .2 & \text { Subjecten } & 47\end{array}$

$\begin{array}{lll}4.3 .3 & \text { Procedure } & 48\end{array}$

$\begin{array}{lll}\text { 4.3.4. Statistische analyse } & 50\end{array}$

4.3.4.1 Validiteit $\quad 50$

4.3.4.2 Wegingsfactoren 51

4.3.4.3 Generaliseerbaarheidsanalyses 51

$4.4 \quad$ Verwachtingen 53

4.4.1 Uitvoerbaarheid van het onderzoek 53

4.4.2 Validiteit 54

4.4.3 Wegingsfactoren 54

4.4.4 Generaliseerbaarheidsanalyses

4.4.5 Waardering van de beoordelingsmethoden $\quad 55$

4.5 Hypothesen 55

$4.6 \quad$ Resultaten 56

4.6.1 Constructie van het onderzoeksmateriaal 56

4.6.2 Validiteit 57

4.6.3 Wegingsfactoren $\quad 59$

$\begin{array}{lll}\text { 4.6.4 Generaliseerbaarheidsanalyses } & 60\end{array}$

4.6.4.1 G-studie 60

4.6.4.2 D-studies 61

4.6.4.2.1 Interbeoordelaarsbetrouwbaarheid 61

4.6.4.2.2 Totale toetsbetrouwbaarheid 61

4.6.5 Waardering van de beoordelingsmethoden 63

4.7 Conclusies 63

4.7.1 Uitvoerbaarheid van het onderzoek 63

$\begin{array}{lll}4.7 .2 & \text { Validiteit } & 64\end{array}$

4.7.3 Weging 65 
4.7.4 Generaliseerbaarheidsanalyses 66

4.7.4.1 Interbeoordelaarsbetrouwbaarheid 66

4.7.4.2 Totale toetsbetrouwbaarheid 66

4.7.5 Waardering van de beoordelingsmethoden 67

$\begin{array}{lll}4.8 & \text { Implicaties van het pilot-onderzoek voor } & 67\end{array}$

$\begin{array}{lll}\text { 4.8.1 Uitvoerbaarheid van het onderzoek } & 67\end{array}$

$\begin{array}{lll}4.8 .2 & \text { Validiteit } & 69\end{array}$

$\begin{array}{lll}4.8 .3 & \text { Weging } & 70\end{array}$

4.8.4 Generaliseerbaarheidsanalyses 71

4.8.5 Waardering van de beoordelingsmethoden 71

Hoofdstuk 5: Het hoofdonderzoek

$\begin{array}{lll}5.1 & \text { Inleiding } & 73\end{array}$

$\begin{array}{lll}5.2 & \text { Vraagstellingen } & 73\end{array}$

$\begin{array}{lll}5.3 & \text { Methode } & 75\end{array}$

$\begin{array}{lll}5.3 .1 & \text { Materialen } & 75\end{array}$

$\begin{array}{lll}\text { 5.3.2 Subjecten } & 76\end{array}$

$\begin{array}{lll}\text { 5.3.3 Procedure } & 77\end{array}$

$\begin{array}{lll}5.3 .4 & \text { Statistische analyse } & 77\end{array}$

$\begin{array}{lll}\text { 5.3.4.1 Validiteit } & 78\end{array}$

5.3.4.2 Generaliseerbaarheidsanalyses 78

$\begin{array}{lll}\text { 5.3.4.3 Weging } & 81\end{array}$

$5.4 \quad$ Verwachtingen $\quad 81$

5.4.1 Validiteit 81

5.4.2 Generaliseerbaarheidsanalyses $\quad 82$

$\begin{array}{lll}\text { 5.4.2.1 G-studie } & 82\end{array}$

$\begin{array}{lll}5.4 .2 .2 & \text { D-studie } & 84\end{array}$

5.4.3 Weging 84

5.4.4 Waardering van de beoordelingsmethoden $\quad 85$

$5.5 \quad$ Hypothesen $\quad 85$

$\begin{array}{lll}5.6 & \text { Resultaten } & 88\end{array}$

5.6.1 Representativiteit van de steekproef $\quad 88$

$\begin{array}{lll}5.6 .2 & \text { Validiteit } & 88\end{array}$

5.6.3 Generaliseerbaarheidsanalyses 96

$\begin{array}{lll}\text { 5.6.3.1 G-studie } & 96\end{array}$

5.6.3.2 D-studies 99

5.6.3.2.1 Interbeoordelaarsbetrouwbaarheid 99

$\begin{array}{lll}\text { 5.6.3.2.2 } & \text { Totale toetsbetrouwbaarheid } 100\end{array}$

5.6.3.2.3 Betrouwbaarheid van zak/slaag-beslissingen 105

$\begin{array}{lll}5.6 .4 & \text { Weging } & 107\end{array}$

5.6.5 Waardering van de beoordelingsmethoden 114

5.7 Conclusies 116

$\begin{array}{lll}5.7 .1 & \text { Validiteit } & 116\end{array}$

$\begin{array}{lll}\text { 5.7.2 Generaliseerbaarheidsanalyses } & 118\end{array}$ 
$\begin{array}{lll}\text { 5.7.2.1 G-studie } & 118\end{array}$

$\begin{array}{ll}\text { 5.7.2.2 Interbeoordelaarsbetrouwbaarheid } & 120\end{array}$

$\begin{array}{ll}\text { 5.7.2.3 Totale toetsbetrouwbaarheid } & 121\end{array}$

$\begin{array}{lll}\text { 5.7.2.4 Zak/slaag-beslissing } & 122\end{array}$

$\begin{array}{lll}5.7 .3 & \text { Weging } & 122\end{array}$

5.7.4 Waardering van de beoordelingsmethoden 123

Hoofdstuk 6: Discussie en conclusie

$\begin{array}{lll}6.1 & \text { Inleiding } & 125\end{array}$

6.2 Beantwoording van de vraagstellingen 125

$\begin{array}{lll}6.2 .1 & \text { Validiteit } & 125\end{array}$

$\begin{array}{lll}6.2 .2 & \text { Generaliseerbaarheidsanalyses } & 127\end{array}$

$\begin{array}{lll}6.2 .2 .1 & \text { G-studie } & 127\end{array}$

$\begin{array}{lll}\text { 6.2.2.2 Interbeoordelaarsbetrouwbaarheid } & 127\end{array}$

$\begin{array}{lll}6.2 .2 .3 & \text { Totale toetsbetrouwbaarheid } & 128\end{array}$

$\begin{array}{lll}\text { 6.2.2.4 Betrouwbaarheid van zak/slaag-beslissingen } & 129\end{array}$

6.2.3 Weging 130

6.2.4 Waardering van de beoordelingsmethoden 131

$\begin{array}{lll}6.3 & \text { Conclusies } & 132\end{array}$

6.4 Het verschil tussen experimenteel onderzoek 132

6.5 Suggesties voor de onderwijspraktijk 133

$\begin{array}{lll}6.6 & \text { Suggesties voor verder onderzoek } & 134\end{array}$

$\begin{array}{ll}\text { Samenvatting } & 137\end{array}$

$\begin{array}{ll}\text { Summary } & 143\end{array}$

$\begin{array}{ll}\text { Literatuur } & 147\end{array}$

$\begin{array}{ll}\text { Dankwoord } & 156\end{array}$

$\begin{array}{lr}\text { Curriculum vitae } & 157\end{array}$

$\begin{array}{lll}\text { Bijlage 1: } & \text { De casuïstiek } & 159\end{array}$

Bijlage 2: $\quad$ Een voorbeeld van elke beoordelingsmethode 164

$\begin{array}{lll}\text { Bijlage 3: } & 169\end{array}$ 


\section{CONTEXT VAN HET ONDERZOEK}

Het doel van elke medische opleiding is artsen op te leiden die beschikken over voldoende medische kennis en vaardigheden om in de praktijk van de gezondheidszorg patiënten adequaat te behandelen. Deze complexe vaardigheid wordt regelmatig aangeduid als medisch probleemoplossen. Ondanks de nadruk die in het onderwijs op deze aspecten wordt gelegd, blijven deze bij de toetsing veelal onderbelicht. De verklaring hiervoor is het gebrek aan valide en betrouwbare meetinstrumenten.

Bij de Faculteit der Geneeskunde van de Rijksuniversiteit Limburg is het Project Evaluatie van Studieresultaten (PES) belast met de ontwikkeling en implementatie van een adequaat evaluatiesysteem van studieprestaties. In dit interdisciplinaire team zijn zowel artsen, onderwijskundigen als psychometrici werkzaam.

Vanaf de oprichting in 1976 werden vier competentiedomeinen onderscheiden die expliciet in het evaluatiesysteem tot uitdrukking moesten komen, te weten:

(1) Kennis

(2) Vaardigheden

(3) Medisch probleemoplossen

(4) Attitude

In het tijdsplan van PES wordt voor de ontwikkeling van de instrumenten voor de verschillende competentiedomeinen dezelfde volgorde gehanteerd. Op dit moment zijn voor de kennis en vaardigheden een aantal instrumenten ontwikkeld en geimplementeerd. Hoewel nog steeds onderzoek wordt verricht naar de validiteit en de betrouwbaarheid van deze instrumenten, vormen ze een geïntegreerd onderdeel van het examensysteem (Van der Vleuten \& Verwijnen, 1990). Voor het competentiedomein medisch probleemoplossen zijn alleen de globale stagebeoordelingen en bij sommige vakgroepen het zogenaamde gestructureerd mondeling examen als instrumenten voorhanden. Het ontwikkelen van een schriftelijke instrument voor dit competentiedomein vormt een belangrijk aandachtspunt. In het kader hiervan is het onderzoek dat in deze dissertatie is beschreven, uitgevoerd.

Binnen het onderwijs spelen toetsen een belangrijke rol. Met een toets wordt nagegaan in hoeverre de studenten de gestelde leerdoelen hebben bereikt. De meest eenvoudige manier om te achterhalen wat een student weet en kan is het rechtstreeks te vragen. Toetsen bestaan dan ook uit vragen of opdrachten die de student in de gelegenheid stelt zijn/haar kennis en kunde te demonstreren.

Globaal genomen kunnen twee typen toetsvragen worden onderscheiden: (1) gesloten vragen en (2) open vragen. Tot de eerste categorie vragen behoren onder andere multiple choice vragen, juist/onjuist vragen en aanvulvragen. Onder open vragen worden al die type vragen verstaan waarbij het antwoord niet uit één woord bestaat, maar uit eén of meerdere zinnen. Voorbeelden van de laatste groep zijn in- en aanvulvragen, kortantwoordvragen, lang-antwoordvragen en opstelvragen.

Bij de keuze voor een vraagvorm is het van belang onderscheid te maken tussen open en gesloten antwoorden. Dit betreft niet het verschil tussen het meten van kennis en inzicht, 
maar het gaat hierbij om de vraag in hoeverre het gewenste antwoord reeds van tevoren in details is vast te leggen. Indien het mogelijk is het juiste antwoord in enkele woorden kort weer te geven, dan is een gesloten vraagvorm bruikbaar. Als het gewenste antwoord bestaat uit een reeks gegevens, waarbij meerdere goede antwoorden mogelijk zijn en waarvan de juistheid slechts in onderlinge samenhang kan worden beoordeeld, dan zijn open vraagvormen noodzakelijk.

Op het gebied van schriftelijke simulatie-instrumenten voor het meten van vaardigheid in medisch probleemoplossen bestaat een lange traditie. In het algemeen bestaan deze instrumenten uit een aantal korte patiëntbeschrijvingen (casus), aan de hand waarvan één of meerdere vragen moeten worden beantwoord. Hierbij worden geregeld verschillende varianten van open vraagvormen toegepast.

Het beoordelen van antwoorden op open vragen brengt specifieke problemen met zich mee. Het onderzoek dat in deze dissertatie wordt beschreven, heeft tot doel inzicht te verschaffen in de beoordelingsproblematiek bij open vraagvormen. Met name de invloed van structurering van beoordelingsmethoden, de inhoudsdeskundigheid van de beoordelaar en positieve weging op betrouwbaarheid en validiteit is bestudeerd.

Allereerst wordt in hoofdstuk 1 een historisch overzicht gegeven van de belangrijkste schriftelijke simulatie-instrumenten voor medisch probleemoplossen, het competentiedomein waarin het onderzoek is uitgevoerd. Hierbij wordt tevens ingegaan op de psychometrische kwaliteiten, zoals de validiteit en betrouwbaarheid. Het hoofdstuk wordt afgesloten met de meest recente ontwikkelingen op het gebied van schriftelijke simulatieinstrumenten, waarbij de nadruk ligt op instrumenten waarin open vraagvormen worden toegepast.

In het tweede hoofdstuk wordt vervolgens nader ingegaan op de problemen die zich bij het beoordelen van open vragen kunnen voordoen. Met name de verschillende aspecten die de betrouwbaarheid van het beoordelingsproces kunnen beïvloeden, komen in dit hoofdstuk aan de orde.

In hoofdstuk 3 komen de achtergronden en de vraagstellingen van het onderzoek aan de orde, waarbij tevens een globale beschrijving wordt gegeven van het onderzoeksdesign. Aangezien de gehanteerde benaderingswijze voor het schatten van betrouwbaarheid consequenties heeft voor de aspecten die in het onderzoek kunnen worden bestudeerd, wordt in dit hoofdstuk een expliciete keuze voor een betrouwbaarheidstheorie gemaakt. Voorafgaande aan deze keuze wordt in dit hoofdstuk een beknopt overzicht gegeven van de drie belangrijkste benaderingswijzen voor het schatten van betrouwbaarheid. Het derde hoofdstuk wordt afgesloten met de algemene hypothesen die aan het onderzoek ten grondslag lagen.

Het onderzoek is in twee fasen uitgevoerd. De doelstellingen en de resultaten van het pilot-onderzoek worden in hoofdstuk 4 beschreven. In de laatste paragraaf van dit hoofdstuk wordt ingegaan op de consequenties van de bevindingen voor het hoofdonderzoek.

De opzet, de uitvoering en de resultaten van het hoofdonderzoek komen in hoofdstuk 5 aan de orde. Aan het eind van dit hoofdstuk worden de hypothesen getoetst aan de resultaten van het hoofdonderzoek.

In het laatste hoofdstuk worden de vraagstellingen die aan het onderzoek ten grondslag lagen beantwoord en conclusies getrokken. Tevens worden in dit hoofdstuk de bevindingen in een breder kader geplaaist en worden suggesties gedaan voor verder onderzoek. 

METEN VAN VAARDIGHEID IN MEDISCH PROBLEEMOPLOSSEN

\subsection{Inleiding}

Vanaf de Tweede Wereldoorlog zijn schriftelijke examens een steeds belangrijkere plaats gaan innemen in de medische opleiding. Met name het gebruik van gesloten vraagvormen zoals meerkeuze-vragen, nam in de jaren vijftig toe. Gezien de aard van de toetsvorm ontstond de zorg dat bepaalde complexe en hogere cognitieve vaardigheden, zoals medisch probleemoplossen, niet of in onvoldoende mate in het examensysteem aan de orde kwamen (Gerritsma \& Smal, 1974). Tevens was een groeiende onvrede met de traditionele klinische examens waameembaar. Ethische problemen, maar ook de subjectiviteit van de beoordelingen en het ontbreken van expliciete en uniforme criteria lagen aan deze onvrede ten grondslag.

In het begin van de jaren zestig is met name in de Verenigde Staten van Amerika een start gemaakt met het ontwikkelen van schriftelijke simulatietechnieken voor het meten van vaardigheid in medisch probleemoplossen.

In dit hoofdstuk wordt een overzicht gegeven van de belangrijkste ontwikkelingen op het gebied van schriftelijke simulatie-instrumenten voor medisch probleemoplossen. Tevens wordt op de validiteit en betrouwbaarheid van deze instrumenten ingegaan.

\subsection{Schriftelijke simulatie-instrumenten: een overzicht}

Het eerste schriftelijke simulatie-instrument voor het meten van medisch probleemoplossen werd ontwikkeld door Rimoldi (1955, 1960, 1961, 1963). Deze "Test of Diagnostic Skills" bestaat uit korte casus-beschrijvingen en een groot aantal genummerde kaartjes waarop én anamnese-vraag of én onderdeel van het lichamelijk-, laboratorium- of instrumenteel/technisch onderzoek staat vermeld. Op de achterkant van elk kaartje wordt het antwoord of de uitslag van de desbetreffende optie gegeven. De bij een casus behorende set van kaartjes omvat alle potentiële opties die voor het komen tot de juiste (waarschijnlijkheids)diagnose van belang kunnen zijn. 
Nadat de student de casus heeft gelezen, begint hij met het kaartje om te draaien waarop de optie staat waarin hij het meest is geïnteresseerd. Dit proces wordt herhaald totdat de student het idee heeft over voldoende informatie te beschikken om tot de gevraagde waarschijnlijkheidsdiagnose te kunnen komen. Het aantal, de volgorde en de soort opties die de student heeft gekozen, wordt omgezet in een zogenaamde utiliteitsscore. Deze score en de gegeven diagnose vormen de test-score van de student.

Op basis van de bevindingen van Rimoldi, startten McGuire en collega's (o.a. McGuire \& Babbott, 1967) met het ontwikkelen van de zogenaamde Patient Management Problems (PMP). Een PMP bestaat uit een casus-beschrijving waarin de belangrijkste informatie met betrekking tot een patiënt en zijn directe (sociale) omgeving is opgenomen. Daarbij zijn lijsten met opties gevoegd waaruit de student kan kiezen. Deze opties zijn over de categorieën anamnese, lichamelijk onderzoek, laboratorium bepalingen en therapie ("management") verdeeld. De antwoorden op de opties staan achter het desbetreffende item en kunnen met behulp van een speciale pen zichtbaar worden gemaakt.

In de loop der tijd zijn verschillende soorten PMP's ontwikkeld, die kunnen worden onderverdeeld in lineaire PMP's en vertakte (branching) PMP's (Hubbard et al., 1965; McGuire, 1976; Hubbard, 1978; Harden, 1983; Skakun et al., 1979).

Bij een lineaire PMP moeten de verschillende onderdelen van het PMP in een vaste volgorde worden doorlopen. De student kiest hierbij per onderdeel de opties die volgens hem van belang zijn, waarna hij wordt geïnstrueerd met welk onderdeel moet worden doorgegaan. Het voordeel van deze methode is dat iedereen die tot de goede oplossing komt, dezelfde route heeft doorlopen. Het nadeel is echter dat weinig tot geen ruimte wordt gelaten aan individuele inbreng en/of strategieën van een student.

Aan dit laatste bezwaar wordt tegemoet gekomen door het vertakte PMP. Bij dit simulatie-instrument is de student totaal vrij in de keuze met betrekking tot de volgorde waarin de verschillende onderdelen worden doorlopen. Het is zelfs toegestaan om op elk moment naar eerdere onderdelen terug te keren. Doordat de student nu de vrijheid heeft een eigen oplossingsstrategie te kiezen, ontstaat echter wel het gevaar dat de student halverwege het PMP vastloopt.

De basisprincipes van het lineaire PMP zijn ook in andere instrumenten als uitgangspunt genomen. Een eerste variant is de Problem Box. Dit instrument bestaat eveneens uit een korte casus en een lijst met te kiezen opties. In tegenstelling tot het PMP worden bij de Problem Box de antwoorden op de gekozen opties niet schriftelijk gegeven, maar zijn de materialen daadwerkelijk aanwezig. Zo kan een anamnese op een bandje zijn opgenomen of kunnen röntgen-foto's van de patiënt zijn bijgevoegd. Evenals bij het PMP wordt elk onderdeel afgesloten met een open of gesloten vraag, waarna met het volgende onderdeel kan worden doorgegaan. Een variant op de Problem Box is het Focal Problem. Het verschil tussen beide instrumenten is dat bij het Focal Problem het originele materiaal niet is bijgevoegd, maar de informatie schriftelijk wordt verstrekt. Daamaast wordt bij het Focal Problem alleen gebruik gemaakt van open vragen die door de student schriftelijk moeten worden beantwoord.

Zowel bij het PMP, de Problem Box als bij het Focal Problem is het risico aanwezig dat een onervaren persoon het patiëntprobleem vanaf het eerste begin verkeerd aanpakt en/of vroegtijdig vastloopt. Aan dit probleem wordt tegemoet gekomen door het Sequential Management Problem (Berner et al., 1974; Martin, 1975). Overeenkomstig het PMP wordt de student een casus voorgelegd waama per onderdeel één of meer opties kunnen 
woŕden gekozen. Elk onderdeel wordt afgesloten met een open of gesloten vraag. Aan het begin van ieder onderdeel krijgt de student nadere informatie over de patiënt, die van belang is voor het desbetreffende gedeelte (bijv. welk lichamelijk onderzoek is verricht en wat hiervan de resultaten zijn). Deze informatie omvat tevens het antwoord op de eerder gestelde vraag. Hierdoor is het theoretisch mogelijk dat een student die in een bepaald gedeelte te weinig informatie heeft verzameld (en de afsluitende vraag verkeerd heeft beantwoord) het resterende gedeelte van de SMP foutloos doorloopt.

Een instrument voor het meten van medisch probleemoplossen dat alleen gebruik maakt van open vragen is de methode van de Gestructureerde Open Vraag (GOV), ook wel aangeduid met Modified Essay Question (MEQ) (Knox, 1975; Feletti, 1980; Van de Lisdonk \& Kartodirdjo, 1980; Ten Cate, Van Duijn \& Van Versfelt, 1981; Feletti \& Smith, 1986).

De GOV bestaat uit een boekje waarin op de eerste pagina een casus-beschrijving wordt gegeven. In deze openings-scene is relevante informatie opgenomen met betrekking tot zowel de medische als de sociale achtergrond van de patiënt. Op elke daaropvolgende pagina van het boekje wordt een open vraag gesteld die de student moet beantwoorden. De vragen zijn zo geformuleerd en afgebakend dat het antwoord in een paar zinnen kan worden gegeven. Nadat de vraag is beantwoord krijgt de student informatie aangeboden die essentieel is voor een goede beantwoording van de volgende vraag. De antwoorden van de studenten worden met behulp van model-antwoorden en bijbehorende puntenbeoordeling nagekeken.

De psychometrische kwaliteiten van deze instrumenten zijn op grote schaal bestudeerd (o.a. Sedlacek \& Nattress, 1972; Goran et al.. 1973; Schumacher, 1973; Norman \& Feightner, 1981; Feletti \& Smith, 1986). Ondanks de grote diversiteit aan schriftelijke simulaties en de verschillende situaties waarin deze instrumenten zijn gebruikt en onderzocht, komen enkele algemene trends in de gevonden psychomerrische kwaliteiten naar voren. In de volgende paragrafen wordt ingegaan op de scoring, de betrouwbaarheid en de validiteit van dergelijke schriftelijke simulatie-technieken.

\subsection{Scoring van schriftelijke simulatie-instrumenten}

\subsubsection{Scoren aan de hand van categorieën}

Bij een aantal scoringsmethoden voor schriftelijke simulaties worden de opties verdeeld over verschillende categorieën. Deze indeling is gebaseerd op de mate waarin de opties van belang zijn voor het op een adequate manier "oplossen" van het klinische probleem. De manier waarop de opties over de verschillende categorieën worden verdeeld, is het resultaat van een discussie tussen experts. Als over een optie geen consensus kan worden bereikt, wordt deze optie uit de lijst verwijderd. Een veel gehanteerde indeling wordt hieronder weergegeven (Norcini et al., 1983; Webster et al., 1988). Achter elke categorie staat de bijbehorende wegingsfactor vermeld, zoals gebruikt bij de American Board of Internal Medicine. Deze waarden zullen in de hierna volgende voorbeelden worden gebruikt. 
(a) geïndiceerd en essentieel

(b) geïndiceerd maar niet essenticel

(c) noch geïndiceerd noch niet geïndiceerd

(d) niet geïndiceerd maar niet schadelijk

(e) niet geïndiceerd en duur of risicovol

(f) niet geïndiceerd en gevaarlijk

Bij het bepalen van de score wordt in eerste instantie per categorie het aantal gekozen opties geteld en vermenigvuldigd met de wegingsfactor van de desbetreffende categorie. Deze tellingen vormen de ruwe scores en geven het patroon weer van het aantal en de aard van de gekozen opties.

Op basis van deze ruwe scores kunnen verschillende, meer classificerende scores worden bepaald. De meest gebruikte scores zijn de "proficiency score" en de "efficiency score", (McGuire \& Babbott, 1967; Webster et al., 1988).

De "proficiency score" wordt gezien als een maat voor de totale vaardigheid ("overall skill") die bij een casus benodigd is en is de gewogen som van alle gekozen opties gedeeld door het maximum aantal te behalen punten. De mate waarin een student effectief en economisch handelt, wordt uitgedrukt in de "efficiency score". Deze score komt overeen met de proportie geïndiceerde opties die door de student is gekozen (McGuire et al., 1973).

In formule:

$$
\begin{aligned}
& \text { PROFICIENCY }=\frac{(10 a+5 b+0 c-2 d-5 e-12 f)}{\left(10 a_{\max }+5 b_{\max }\right)} \\
& \text { EFFICIENCY }=\frac{(a+b)}{(a+b+c+d+e+f)}
\end{aligned}
$$

Een probleem dat echter bij het gebruik van proficiency en efficiency scores werd geconstateerd, is dat de efficiënte probleemoplosser minder informatie verzamelt en hiervoor wordt gestraft doordat hij minder punten verzamelt. Een oplossing is om per categorie een maximaal aantal punten toe te kennen dat lager is dan de som van het aantal positieve punten in de desbetreffende categorie. Hierdoor wordt vermeden dat studenten heel veel informatie verzamelen en is tevens de mogelijkheid geschapen om, net als in de praktijk, verschillende goede oplossingsstrategieën toe te passen (Marshall, 1977). Deze methode lijkt veelbelovend maar is nog te weinig onderzocht om hierover uitspraken te kunnen doen (Swanson et al., 1989).

In andere studies (o.a. Grosse, 1981) werden eveneens kanttekeningen bij proficiency en efficiency scores geplaatst. Het lijkt aannemelijk dat studenten die veel geindiceerde opties kiezen, en dus over voldoende kennis en inzicht beschikken, weinig tot geen contra-geïndiceerde opties zullen kiezen. In verschillende studies (o.a. Grosse, 1981) werd echter een positieve correlatie tussen het aantal gekozen geïndiceerde en het aantal 
gekozen niet-geindiceerde opties gevonden; studenten kozen ofwel veel danwel weinig opties uit beide categorieën. Wanneer per student de verkregen punten (geïndiceerde opties) en de "strafpunten" (niet geïndiceerde opties) bij elkaar werden opgeteld, bleek tussen personen weinig variatie te bestaan in de behaalde totaal-scores. Uit deze resultaten werd de conclusie getrokken, dat per student een aparte score moet worden bepaald voor zowel het aantal gekozen geïndiceerde als het aantal gekozen niet geïndiceerde opties. Op deze wijze kan beter inzicht worden verkregen in hetgeen de student daadwerkelijk weet en wordt gokgedrag tegengegaan. De in de literatuur voorkomende benamingen voor deze scores zijn: select vs. omit, throughness vs. non-select en errors-of-omission vs. commission (Webster et al., 1988). Uitgaande van bovenstaande categorieën, worden beide scores als volgt berekend:

$$
\begin{aligned}
& \text { SELECT }=1-\frac{(10 a+5 b)}{\left(10 a_{\max }+5 b_{\max }\right)} \\
& \text { OMIT }=1-\frac{(2 d+6 e+12 f)}{\left(2 d_{\max }+6 e_{\max }+12 f_{\max }\right)}
\end{aligned}
$$

\subsubsection{Aggregate scoring}

Een andere gebruikte scoringsmethode is de "aggregate scoring" zoals ontwikkeld door Norman (1985). Bij deze methode wordt de simulatie door een groep "experts" op het inhoudsgebied doorlopen om inzicht te verkrijgen in de opties die van belang zijn voor een adequate handelswijze. De proportie van het aantal keren dat de optie door de groep experts wordt gekozen is het gewicht dat aan een optie wordt toegekend. In tegenstelling tot de hiervoor beschreven methode is de wegingsfactor niet de consensus van een groep deskundigen, maar wordt het gewicht empirisch bepaald door het aantal keren dat de optie door een groep "experts" wordt gekozen.

De score van een student is de som-score van de gewichten van de door hem gekozen opties gedeeld door de maximaal te behalen score. Deze score geeft dus aan in welke mate de handelswijze van de student overeenstemt met die van de experts.

Deze scoringsmethode is slechts op beperkte schaal aan onderzoek onderworpen (o.a. Norcini, 1987; Webster et al., 1988). In deze studies werd aggregate scoring vergeleken met de hiervoor beschreven "category scoring". Uit de resultaten bleek dat beide scoringsmethoden hoog correleerden en weinig verschillen opleverden met betrekking tot de toetsbetrouwbaarheid en validiteit van het meetinstrument. Tevens bleek dat het merendeel van de opties dat door de "experts" bij aggregate scoring werd gekozen overeenkwam met de geïndiceerde opties bij category scoring.

\subsubsection{Overige scoringsmethoden}

Naast boven beschreven scoringsmethoden zijn nog verschillende andere methoden ontwikkeld, zoals "pathway scoring methods" en "Boolean scoring methods". Gezien de 
beperkte toepassing van deze methoden zullen deze methoden niet nader worden toegelicht, maar wordt voor meer informatie verwezen naar Swanson et al. (1989).

\subsection{Betrouwbaarheid van schriftelijke simulatie-instrumenten}

In de literatuur (o.a. Thomdike, 1982) worden verschillende vormen van betrouwbaarheid onderscheiden. Bij elke vorm van betrouwbaarheid gaat het om de vraag hoe goed de gevonden resultaten kunnen worden gerepliceerd. Onderzoek naar de betrouwbaarheid van schriftelijke simulatie-instrumenten laat zich onderscheiden in studies naar interbeoordelaars- en intercasebetrouwbaarheid.

\subsubsection{Interbeoordelaarsbetrouwbaarheid}

Uit de vorige paragraaf komt onder andere naar voren dat een groot aantal scoringsmethoden voor schriftelijke simulatie-instrumenten weinig of geen recht doet aan de eigen werkwijze van een hulpverlener. Dit is aanleiding tot bezorgdheid aangezien zelfs bij professionele artsen een zekere mate van variatie in handelswijze waarneembaar is (Elstein et al., 1978). Bij het beoordelen kan deze subjectiviteit een vermindering van de overeenstemming tussen beoordelaars tot gevolg hebben.

De interbeoordelaarsbetrouwbaarheid is met name bestudeerd in relatie tot de ontwikkeling van scoringssleutels voor PMP's. In deze studies werd artsen gevraagd een aantal PMP's te maken. Op basis van de gekozen opties werd vervolgens de optimale behandelingswijze vastgesteld. Uit de resultaten bleek de overeenstemming tussen experts over de juiste werkwijze gering te zijn (o.a. Sedlacek \& Nattress, 1972; Mazzuca \& Cohen, 1982; Norcini, 1987). De mate van overeenstemming varieerde echter per onderdeel van het PMP. Desondanks kan worden geconcludeerd dat zowel bij de ontwikkeling van de scoringsmethode als bij het beoordelen van de resultaten, meerdere inhoudsdeskundigen moeten worden betrokken om de meetfouten door instabiliteit van beoordelaars te reduceren.

\subsubsection{Intercasebetrouwbaarheid}

In onderzoek naar de intercasebetrouwbaarheid is met name aandacht besteed aan de mate waarin het behaalde resultaat op een casus overeenkomt met, of een voorspellende waarde heeft voor de score op een andere casus.

Uit deze studies bleek dat de behaalde score op de ene casus weinig tot geen indicatie gaf voor het presteren op een andere casus (o.a. Donnelly et al., 1974; Berner et al., 1977; Barrows et al., 1978; Elstein et al.. 1978; Swanson et al., 1982; Wolf et al.. 1983; Barrows et al., 1987). Op basis van deze gegevens lijkt te kunnen worden geconcludeerd dat medisch probleemoplossen een vaardigheid is die sterk is gerelateerd aan deXinhoud van het probleem. In de literatuur wordt dit verschijnsel aangeduid als het probleem van de inhoudsspecificiteit (Elstein et al., 1978).

Aangezien de verschillende casus kunnen worden opgevat als items binnen een test, zal de toetsbetrouwbaarheid van een casustoets laag uitvallen (Swanson et al., 1989). Om toch tot voldoende betrouwbare uitspraken te kunnen komen, is het noodzakelijk een groot 
aantal verschillende casus in een toets op te nemen.

\subsection{Validiteit van schriftelijke simulatie-instrumenten}

In de literatuur worden tientallen soorten validiteit onderscheiden (Van Berkel, 1984). Hieruit blijkt dat een instrument verschillende vormen van validiteit kan bezitten, afhankelijk van de invalshoek die wordt gekozen. Bij elke vorm van validiteit staat de vraag centraal in welke mate het meetinstrument voldoet aan het beoogde doel.

In een groot aantal studies is aandacht besteed aan diverse aspecten van validiteit van schriftelijke instrumenten voor medisch probleemoplossen. In het onderstaande overzicht wordt ingegaan op de construct, de concurrent en de predictieve validiteit.

\subsubsection{Construct validiteit}

Construct validiteit geeft aan in welke mate de bedoelde kwaliteiten door een test worden gemeten. Hierbij wordt een construct opgevat als een attribuut dat via de toetsscore tot uitdrukking komt (Cronbach \& Meehl, 1955). Het gaat dus om de geldigheid van de operationalisatie van de te meten eigenschap in de vorm van een specifiek instrument.

In verschillende studies is de construct validiteit van PMP's onderzocht door de behaalde scores van twee of meer groepen personen, die verschildenXin het aantal jaren gevolgd onderwijs, te vergelijken (o.a. Hubbard, 1978; Schumacher, 1973). Uit de resultaten bleek dat de score toenam naarmate de personen meer onderwijs hadden gevolgd, hetgeen werd opgevat als een indicatie voor construct validiteit. In een aantal experimenten was een dergelijke trend echter minder eenduidig waarneembaar (o.a. Levine \& Noak, 1968; Miller, 1968; Levine, 1967; Newble et al., 1982).

De construct validiteit is eveneens onderzocht met behulp van factoranalyse (o.a. Juul et al., 1974). Uit factoranalytisch onderzoek komen verschillende resultaten naar voren. Bij sommige studies (o.a. Donnelly et al., 1974) werd bijvoorbeeld één onderliggende factor, te weten data-verzameling, gevonden terwijl in ander onderzoek (bijv. Bemer et al., 1977) verschillende stabiele factoren werden onderscheiden.

Bij factoranalytisch onderzoek naar vaardigheid in medisch probleemoplossen doen zich twee problemen voor: enerzijds worden kleine steekproeven gebruikt, anderzijds blijkt de intercasebetrouwbaarheid laag te zijn, waardoor de kans op het vinden van één of een beperkt aantal valide factoren die de gevonden resultaten kunnen verklaren, wordt verkleind (Swanson et al., 1989).

In principe is het mogelijk om in toekomstig onderzoek aan het probleem van de kleine steekproeven tegemoet te komen door eenzelfde casustoets aan een groot aantal personen voor te leggen. De lage intercasebetrouwbaarheid vormt echter een belangrijker probleem. Zoals in paragraaf 1.4 .2 is beschreven, wordt bij instrumenten voor het meten van medisch probleemoplossen de intercasebetrouwbaarheid negatief beïnloed door het probleem van de inhoudsspecificiteit. Om tot een acceptabele betrouwbaarheid te kunnen komen moet een toets uit een groot aantal casus bestaan. Uit onderzoek (o.a. Swanson et al., 1989) blijkt dat 8 tot 12 uur toetstijd noodzakelijk is om te komen tot een minimale betrouwbaarheid van 0.80 . Het zal duidelijk zijn dat een dergelijke toetstijd praktisch niet realiseerbaar is. 
Over het geheel genomen zijn de resultaten met betrekking tot de construct validiteit van schriftelijke simulaties voor het meten van vaardigheid in medisch probleemoplossen wisselvallig.

\subsubsection{Concurrent validiteit}

De mate waarin de gevonden resultaten (bijv. toetsscores) overeenstemmen met gelijktijdig beschikbare criteriumgegevens wordt aangeduid met concurrent validiteit.

Het onderzoek naar de concurrent validiteit van schriftelijke simulatie-instrumenten is onder te verdelen in enerzijds studies naar discriminante validiteit en anderzijds onderzoek naar convergerende validiteit (Feightner, 1985).

Er is sprake van discriminante validiteit als de resultaten op verschillende tests, die iets anders beogen te meten, niet of nauwelijks correleren. Een hoge correlatie tussen de scores op tests, waarvan wordt verwacht dat ze hetzelfde meten, wordt gezien als een indicatie voor convergerende validiteit.

In onderzoek naar discriminante validiteit werd met name de relatie tussen de scores op multiple-choice vragen en schriftelijke simulaties onderzocht (McGuire \& Babbott, 1967; Schumacher, 1973; Schumacher, 1974; Skakun et al., 1979; Case, 1981; Wolf et al., 1983; Wolf et al., 1985). In deze studies werd iedere keer een lage correlatie gevonden op grond waarvan werd geconcludeerd dat simulaties de mogelijkheid bieden aspecten van medische competentie te meten die niet met "conventionele" instrumenten kunnen worden gemeten.

De vraag is of dit de enige juiste verklaring en conclusie is. Een mogelijke andere verklaring zou bijvoorbeeld kunnen zijn dat de lage correlaties het gevolg zijn van de lage betrouwbaarheid van de schriftelijke simulatie-toetsen. In een aantal studies (Norcini et al., 1984, 1985) werd deze mogelijkheid onderzocht door de correlatie tussen multiplechoice vragen en schriftelijke simulaties te berekenen na de correctie voor attenuatie. Het bleek dat na deze correctie voor de onbetrouwbaarheid van beide instrumenten de correlatie-coëfficiënten beduidend hoger waren (variërend van 0.75 tot 0.97 ) dan in de eerder beschreven studies. Op basis van deze bevindingen werd de discriminante validiteit van schriftelijke simulatie-instrumenten dan ook in twijfel getrokken.

De convergerende validiteit is voornamelijk onderzocht door het gedrag van artsen in de praktijk te vergelijken met hun antwoorden op inhoudelijk gelijke PMP's. Hierbij werd een hoge correlatie tussen de bij het PMP gekozen opties en het vertoonde gedrag in de praktijksituatie als een indicatie voor convergerende validiteit opgevat (McGuire, 1963, 1967; Goran et al., 1973; Rethans \& Van Boven, 1987). Uit de resultaten bleek dat de artsen bij de PMP's significant meer informatie verzamelden dan in de praktijksituatie. Als mogelijke verklaringen voor dit fenomeen werden de volgende factoren genoemd (Goran et al., 1973; Rethans et al., 1990):

(1) In de praktijksituatie moet meer rekening worden gehouden met economische- en tijdsaspecten,

(2) Bij een PMP wordt de arts "gestuurd" door de lijst met opties ("cueing"), waardoor het aantal handelingen kunstmatig wordt verhoogd,

(3) Hetgeen bij een PMP gemeten wordt, is de intentie die de arts heeft om iets te doen (of te vragen), terwijl in de praktijk de handeling daadwerkelijk moet worden verricht en negatief kan worden beïnloed doordat de arts bepaalde vaardigheden minder goed beheerst, 
(4) Er is een verschil tussen hetgeen een arts kan ("competence") en hetgeen een arts in de praktijk toepast ("performance").

Het door Goran et al. (1973) genoemde effect van "cueing" werd reeds eerder gesignaleerd door McCarthy (1966), die in een onderzoek bij studenten vond dat bij PMP's $25 \%$ meer informatie werd ingewonnen en dat de behaalde scores $50 \%$ hoger lagen dan op het mondelinge examen. Tevens bleek de rangordening van de studenten op basis van de PMP-scores anders te zijn dan die op basis van de mondelinge examens.

Wat betreft discriminante en convergerende validiteit worden wisselende resultaten gerapporteerd. Op basis van deze resultaten kan voorlopig worden geconcludeerd dat de concurrent validiteit van schriftelijke simulaties te wensen overlaat.

\subsubsection{Predictieve validiteit}

Predictieve validiteit geeft aan in welke mate de voorspellingen die met behulp van een instrument (bijv. een PMP) worden gedaan. overeenstemmen met de gegevens op een later tijdstip.

De predictieve validiteit van schriftelijke simulaties voor medisch probleemoplossen is slechts in een beperkt aantal studies onderzocht (Pawluk et al., 1976; Nerenberg et al., 1978). In deze studies werden PMP-scores gerelateerd aan praktijkbeoordelingen op een later tijdstip. Op deze manier gemeten, bleken de PMP-scores enige mate van voorspellende waarde te bezitten. Aan deze experimenten kleefden echter methodologische tekortkomingen. Allereerst ontbraken de juiste instrumenten waarmee het te voorspellen gedrag in de praktijk betrouwbaar en valide kon worden gemeten. Daarnaast bleek het niet mogelijk een design te ontwikkelen waarin alle storende variabelen op een adequate wijze konden worden beheerst.

Op basis van het tot nu toe gerapporteerd onderzoek kunnen dan ook geen conclusies worden getrokken met betrekking tot de predictieve validiteit.

Uit bovenstaande validiteits- en betrouwbaarheidsstudies kan worden afgeleid, dat een aantal vraagtekens dient te worden geplaatst bij de kwaliteit van de verschillende schriftelijke simulatie-instrumenten. Uit de validiteitsstudies bleek dat de instrumenten slechts een beperkte mate van construct en concurrent validiteit bezaten. Daamaast werd in een aantal studies een discrepantie gesignaleerd tussen de gekozen opties bij een PMP en de activiteiten die de artsen in de praktijk verrichtten. Dit laatste werd door de onderzoekers met name verklaard als het gevolg van cueing. Maar ook het feit dat ervaren artsen zogenaamde "illness scripts" in het hoofd hebben, en zodoende in de praktijk minder aanvullende informatie nodig hebben, zou hieraan ten grondslag kunnen liggen.

Met betrekking tot de betrouwbaarheid werd geconstateerd dat de overeenstemming tussen experts (zowel wat betreft de gegeven beoordelingen als bij het opstellen van de antwoordsleutels) te wensen overliet. Daarnaast bleek de behaalde score op de ene casus nauwelijks een voorspellende waarde te hebben voor de score op een andere casus. 


\subsection{Recente ontwikkelingen op het gebied van instrumenten voor het meten van vaardigheid in medisch probleemoplossen}

In de meest recente instrumenten voor het meten van vaardigheid in medisch probleemoplossen wordt getracht het probleem van de inhoudsspecificiteit aan te pakken. De nadruk ligt hierbij op het ontwikkelen van efficiënte simulatie-instrumenten, zodat in een korte tijdspanne een groot aantal casus aan een student kan worden aangeboden.

Een voorbeeld van een recent ontwikkeld instrument is SIMP (Simulation of Initial Medical Problem-solving; De Graaff, 1989). SIMP bestaat uit korte casus, die medisch inhoudelijk gericht zijn op de huisartspraktijk. Bij elke casus is een aantal korte open vragen opgenomen, waarin de student moet aangeven wat hij op dat moment zou doen. De vragen zijn onderverdeeld over de vier standaard-categorieën anamnese, lichamelijk onderzoek, diagnose en behandeling. De antwoorden worden beoordeeld met behulp van uit trefwoorden bestaande antwoordsleutels.

De psychometrische kwaliteiten van het instrument zijn in een aantal studies onderzocht (De Graaff, 1988; De Graaff et al., 1987, 1989).

De validiteit van de SIMP is onder andere bestudeerd door de resultaten op de SIMP te vergelijken met de resultaten van dezelfde studenten bij een simulatie-patiënten-contact. De resultaten lieten een duidelijke correlatie tussen beide scores zien $(0.74)$, hetgeen werd geinterpreteerd als een ondersteuning voor de convergerende validiteit. Het feit dat slechts een beperkte correlatie tussen SIMP-scores en een kennistoets werd gevonden (variërend van -0.16 tot 0.25 ), werd opgevat als een bevestiging voor de discriminante validiteit. Hierbij dient echter te worden opgemerkt dat deze correlaties niet zijn gecorrigeerd voor de onbetrouwbaarheid van de gebruikte meetinstrumenten.

Aangezien de SIMP uit open vragen bestaat, worden de antwoorden op deze toets met de hand door beoordelaars gescoord, hetgeen tijdsintensief is en een verlaging van de betrouwbaarheid tot gevolg kan hebben. In studies naar de interbeoordelaarsbetrouwbaarheid bleek deze voldoende te zijn. Tevens bleek de beoordelaarsvariantie relatief weinig invloed te hebben op de totale toetsbetrouwbaarheid (De Graaff, 1989).

Het in de ontwikkelingsfase verkerend Q4-examen van de Canadese Medical Council, waarbij de zogenaamde "key-feature approach" wordt toegepast, is een tweede voorbeeld van een efficiënt instrument voor het meten van vaardigheid in medisch probleemoplossen (Bordage \& Page, 1987).

De "key feature approach" is een uitvloeisel van de traditionele PMP's. Overeenkomstig het PMP wordt een openings-scene gegeven waarin informatie omtrent de patiënt en sociale omgeving wordt vermeld. In tegenstelling met het PMP, wordt bij de "key feature approach" niet van de kandidaat verwacht dat hij alle aspecten van het probleem oplost, maar moet hij vragen over de meest essentiële elementen van het klinische probleem (de "key features") beantwoorden.

Bij de "key-feature approach" worden drie verschillende formaten gehanteerd: (1) invul vragen, (2) kort menu formaat (ongeveer 20 opties) met multiple-choice vragen of afgedekte antwoorden zoals bij het PMP, en (3) lang menu formaat (ongeveer 100 opties). Over de psychometrische kwaliteiten van het instrument is tot op heden slechts zeer summier gepubliceerd. Uit deze gegevens bleek dat bij 69 casus een toetsbetrouwbaarheid van 0.80 werd gevonden, hetgeen overeenkomt met $91 / 2$ uur toetstijd (Page et al., 1990). Over de overeenstemming tussen beoordelaars bij de invulvragen zijn nog geen gegevens beschikbaar. 
De laatste jaren wordt binnen het competentiedomein van medisch probleemoplossen de nadruk gelegd op het ontwikkelen van efficiënte schriftelijke simulatie-instrumenten. Om het effect van cueing te voorkomen, wordt veelvuldig gebruik gemaakt van open vraagvormen. Het beoordelen van antwoorden op open vragen brengt echter specifieke problemen met zich mee.

Op het gebied van factoren die het beoordelingsproces kunnen beïnvloeden is met name in het taalonderwijs onderzoek verricht. Het belangrijkste onderzoek en de daaruit voortvloeiende conclusies komen in het hiernavolgende hoofdstuk aan de orde. 


\section{BEOORDELINGSPROBLEMEN BIJ OPEN VRAAGVORMEN}

\subsection{Inleiding}

Het beoordelen van antwoorden op open vraagvormen blijkt in de praktijk problemen met zich mee te brengen. Naast de grote hoeveelheid tijd die met het beoordelen is gemoeid, vormt de subjectiviteit een potentieel probleem. Uit empirisch onderzoek naar beoordelaarsbetrouwbaarheid blijkt dat gebrek aan overeenstemming tussen beoordelaars een belangrijke bron van onbetrouwbaarheid is. De mate waarin beoordelaarseffecten kunnen optreden, is mede afhankelijk van de kwaliteit van de gehanteerde beoordelingsmethode. In dit hoofdstuk wordt aan beide aspecten aandacht besteed.

\subsection{Empirisch onderzoek naar beoordelaarseffecten}

\subsubsection{Invloed van handschriftkwaliteit en tekstkenmerken}

Het onderzoek naar beoordelaarseffecten is voornamelijk afkomstig uit het taalonderwijs. In deze studies (o.a. Starch \& Elliott, 1912; James, 1927; Sheppard, 1929) werd de invloed van de kwaliteit van het handschrift op het gegeven oordeel onderzocht. De resultaten toonden aan dat beoordelaars een netjes en duidelijk geschreven tekst significant hoger waardeerden dan eenzelfde tekst vervaardigd in een onduidelijk en slordig handschrift. Chase (1968), Briggs (1970) en Markham (1976) vonden enkele decennia later eveneens dat zowel inhoud als kwaliteit van het handschrift significant invloed op de beoordeling had. De interactie tussen inhoud en handschrift bleek echter geen significante invloed op het eindoordeel te hebben (Markham, 1976).

Daarnaast is onderzoek verricht naar de invloed van andere tekstkenmerken op het gegeven oordeel, zoals spelfouten, zinsbouw en lengte van een tekst (o.a. Marshall \& Powers, 1969). Dit onderzoek is globaal te verdelen in studies waarin geschreven commentaar van beoordelaars werd geanalyseerd (o.a. Diedrich et al., 1961; Harris, 1977), onderzoek waarin werd geïnventariseerd in hoeverre beoordelingen van teksten werden beïnvloed door lengte, spelfouten, grammaticale fouten en syntactische complexiteit (o.a Scannel \& Marshall, 1966; Page, 1968; Rosen, 1969; Nold \& Freedman, 1977; 
Crowburst, 1980; Grobe, 1981; Hall et al., 1982) en studies waarin bepaalde kenmerken van antwoorden (b.v. spelfouten) werden gemanipuleerd (o.a. Harris, 1977; Piché et al., 1978; Freedman, 1979; Chase, 1983; Rafoth \& Combs, 1983; Rafoth \& Rubin, 1984). Uit de resultaten bleek dat niet-inhoudelijk gerelateerde tekstkenmerken het beoordelingsproces verstoorden.

\subsubsection{Invloed van verwachtingspatronen}

Het onderzoek van Rosenthal en Jacobson (1968) heeft onder andere aangetoond dat de ideeën die de docenten van hun leerlingen hebben mede bepalend zijn voor de houding van de docent ten opzichte van de leerling. Deze houding blijkt invloed te hebben op zowel de studieprestaties als de ontwikkeling van de desbetreffende leerling.

In andere studies is de samenhang tussen "student-eigenschappen" en verwachtingspatronen bij docenten nader bestudeerd. Uit de resultaten bleek onder andere dat fysiek minder aantrekkelijke kinderen lager worden ingeschat met betrekking tot hun intelligentie (Landy \& Sigall, 1974; Rich, 1975; Ross \& Salvia, 1975) en meer verantwoordelijk worden gehouden voor slecht gedrag en slechte studie-prestaties (Dion, 1972). Daarnaast blijken (aantrekkelijke) vrouwelijke studenten door mannelijke docenten hoger te worden ingeschat dan hun mannelijke collega-studenten (Adams \& La Voie, 1974; Clifton, 19811982). Tevens komt uit verschillende studies naar voren dat docenten over het algemeen een positiever beeld hebben ten aanzien van blanke studenten dan ten aanzien van gekleurde studenten (Cooper et al.. 1975; Aloia et al., 1981; Clifton, 1981-1982; Washington, 1982).

Op basis van deze bevindingen zou kunnen worden verondersteld dat de verwachtingen die een beoordelaar ten aanzien van een persoon heeft ook z'n weerslag kan hebben op de beoordeling van schriftelijk werk. In een aantal experimenten werd dit "expectancy phenomenon" in het beoordelingsproces bestudeerd (Landy \& Sigall, 1974; Dash, 1975; Petrilla, 1978; Chase, 1979; Hughes et al., 1983). Hierin werd de invloed van informatie omtrent de intelligentie en studieresultaten van leerlingen op de beoordeling van de antwoorden op open vragen onderzocht. In elk onderzoek worden significante "expectancy effects" gerapporteerd.

In hoeverre verwachtingspatronen ten aanzien van sexe, huidskleur, intelligentie en fysieke aantrekkelijkheid een weerslag hebben op de beoordeling van schriftelijk materiaal is weinig bestudeerd. Een uitzondering is het onderzoek van Chase (1986). In dit onderzoek werd de invloed van de sexe en de ras van de student, de handschriftkwaliteit en het verwachtingspatroon op het gegeven oordeel voor een antwoord op een open vraag onderzocht. In tegenstelling tot de verwachtingen bleek er een zeer complexe interactie tussen de verschillende variabelen te bestaan.

\subsubsection{Invloed van voorafgaande beoordelingen}

In onderzoek naar visuele perceptie (Helson, 1947; Helson, 1964), sociale beoordelingen (Hovland et al., 1957; Divesta, 1961: Holmes \& Berkowitz, 1961), schatten van gewicht (Sherif et al., 1958), schatten van aantrekkelijkheid van vrouwen (Kenrick \& Gutierres, 1980) en beoordelingen van interviews (Rowe, 1967; Carlson, 1970; Hakel et al., 1970; Wexley et al., 1972; Landy \& Bates, 1973; Koppelman, 1975), bleken voorafgaande 
beoordelingen invloed te hebben op een gegeven oordeel. Naar aanleiding van deze bevindingen werd eveneens onderzoek verricht naar het optreden van dergelijke contrasteffecten bij het beoordelen van open vraagvormen (o.a. Hughes et al., 1980; Hughes et al., 1984).

Eén van de eerste studies met betrekking tot contrast-effecten bij het beoordelen van open vragen werd verricht door Hales \& Tokar (1975). Het bleek dat het criterium antwoord hoger werd gewaardeerd na een set van slechte antwoorden dan wanneer het werd voorafgegaan door een set goede antwoorden.

Soortgelijke resultaten werden in andere studies gevonden (o.a. Hales \& Tokar, 1975; Daly \& Dickson-Markman, 1982). Het lijkt er dan ook op dat het beoordelen van open vragen eveneens gevoelig is voor contrast-effecten. Het is echter nog onduidelijk hoeveel goede/slechte antwoorden minimaal aan het criterium antwoord vooraf moeten gaan om een contrast-effect te veroorzaken.

$\mathrm{Bij}$ het onderzoek naar beoordelaarseffecten kan een aantal kanttekeningen worden geplaatst. Allereerst is het merendeel van de bevindingen afkomstig uit experimentele settings, in plaats van "real life studies". In welke mate de onderzochte factoren invloed hebben in de dagelijkse onderwijspraktijk is op basis van deze studies dan ook niet vast te stellen. In een aantal studies worden geen controle-groepen toegepast. Hierdoor blijft het onduidelijk in hoeverre de gevonden resultaten algemene geldigheid bezitten. Maar ook het feit dat in enkele studies gebruik is gemaakt van minder ervaren beoordelaars kan de validiteit van de uitkomsten hebben beïnvloed.

Desondanks lijkt te kunnen worden geconcludeerd dat de objectiviteit van het beoordelingsproces door tal van factoren negatief kan worden beïnvloed. In hoeverre beoordelaars verschillen in de gevoeligheid voor dergelijke factoren is (nog) onduidelijk. Het is echter bekend dat de kwaliteit van de gebruikte beoordelingsmethode mede bepalend is voor de mate waarin beoordelaarseffecten optreden. Op dit aspect wordt in de volgende paragraaf nader ingegaan.

\subsection{Beoordelingsmethoden voor open vraagvormen}

Idealiter verloopt het beoordelingsproces van open vraagvormen in drie stappen. De eerste fase betreft de constructie van de beoordelingsmethode. Vervolgens wordt met behulp van deze methode een prestatie-oordeel gegeven. Dit betekent dat wordt aangegeven in hoeverre het gegeven antwoord overeenkomt met het goede antwoord. Aan het prestatieoordeel kunnen verschillende waarderingen worden toegekend. Het omzetten van het prestatie-oordeel in een waardering (bijvoorbeeld een schoolcijfer) is de laatste stap in het beoordelingsproces.

De wijze waarop een prestatie-oordeel tot stand komt hangt mede af van de gebruikte beoordelingsmethode. Theoretisch kunnen open vraagvormen op twee manieren worden beoordeeld: globaal en analytisch. Bij de globale methode is de beoordeling gebaseerd op de totale indruk die het antwoord op de beoordelaar maakt. Nadat de beoordelaar het antwoord één of meerdere keren geheel heeft doorgenomen, wordt de impressie omgezet in een waardeoordeel. Vandaar dat deze methode ook wel impressionistisch of holistisch wordt genoemd. Het idee achter de globale beoordelingsmethode is dat de kwaliteit van een geschreven stuk tekst niet noodzakelijkerwijs gelijk behoeft te zijn aan de som van de 
losse onderdelen. Daamaast wordt er van uitgegaan dat de beoordelaars tot overeenstemming kunnen komen over de waarde van de gehele tekst, terwijl dit niet het geval behoeft te zijn voor de verschillende onderdelen van de tekst (Patience \& Swartz, 1987).

Bij de analytische methode wordt gebruik gemaakt van een expliciet beoordelingsschema, waarin verschillende beoordelingscategorieën worden onderscheiden. Per categorie wordt een oordeel gegeven, waarna de onderdelen van de verschillende categorieën tezamen in een eindoordeel worden omgezet. Binnen de analytische benadering is een groot aantal methoden te onderscheiden, die verschillen qua structurering, detaillering en eenduidigheid (Geerligs, 1991). De achterliggende gedachte bij de analytische methode is, dat het in kleine onderdelen beoordelen van een geschreven stuk betere beoordelingen oplevert en de overeenstemming tussen beoordelaars vergroot (De Jong, 1981).

Welke manier van beoordelen het beste is, kan vooralsnog niet eenduidig worden beantwoord. Het grote voordeel van de globale benaderingswijze is dat het beoordelen minder tijd vergt. Tevens biedt deze methode de mogelijkheid om bepaalde unieke kenmerken van een tekst in de beoordeling tot uitdrukking te laten komen. Deze beoordelingswijze is echter minder transparant en is meer gevoelig voor het optreden van beoordelaarseffecten. Analytische beoordelingsmethoden daarentegen geven een duidelijk inzicht in de aspecten die in de beoordeling worden betrokken. Daarnaast kan de analytische methode, mits goed uitgevoerd, tot meer valide en uniforme beoordelingen leiden (Coffman, 1971; Mitchell, 1979; De Jong, 1981). Het belangrijkste nadeel vormt echter de grote tijdsinvestering die met deze beoordelingswijze gepaard gaat (zowel voor de constructietijd als voor de nakijktijd). Bovendien blijkt het in de praktijk vaak moeilijk te zijn om per categorie een onafhankelijk oordeel te vellen (De Jong, 1981; Patience \& Swartz, 1987; Geerligs, 1991).

Voorts hangt de geschiktheid van een beoordelingsmethode samen met het doel van de beoordeling. Zo zal bij het beoordelen van een essay op taalkundige elementen een analytische beoordelingsmethode worden geprefereerd, terwijl een holistische nakijkmethode meer relevant kan zijn bij het beoordelen van een betoogtrant.

De wijze waarop een prestatie-oordeel wordt toegekend, hangt dus voor een groot deel samen met de mate van gestructureerdheid van de beoordelingsmethode. Voor het omzetten van het prestatie-oordeel in een waardering, de derde fase van het beoordelingsproces, zijn eveneens verschillende benaderingswijzen mogelijk. Deze varianten verschillen met name op het aspect van weging. Globaal genomen zijn een viertal wegingsvormen te onderscheiden:

(1) Geen weging; elk onderdeel van de beoordelingsmethode telt even zwaar mee in de waardering.

(2) Posiriele weging: er wordt een onderscheid gemaakt in de waardering van de verschillende onderdelen van de beoordelingsmethode, waarbij alleen punten zijn toe te kennen aan goede antwoorden.

(3) Positi've en negatieve weging; er wordt onderscheid gemaakt in de waardering van de verschillende onderdelen van de beoordelingsmethode, waarbij zowel punten zijn toe te kennen als punten in mindering kunnen worden gebracht.

(4) Kern-items; er wordt een onderscheid gemaakt in de waardering van de verschillende onderdelen van de beoordelingsmethode, waarbij het verschil in waarde tussen de diverse onderdelen dusdanig groot is dat bepaalde onderdelen (de kern-items) de andere onderdelen overschaduwen. 
Het aanbrengen van wegingsfactoren komt voort uit de behoefte om in de beoordeling de belangrijkheid van een bepaalde respons tot uitdrukking te kunnen laten komen. In het geval van negatieve weging bestaat de behoefte om een verkeerde respons af te straffen. Bij simulaties voor medisch probleemoplossen kan dit bijvoorbeeld het geval zijn als de student een "fatale" handeling verricht.

In een aantal studies naar de invloed van wegingsfactoren op de rangordening van de beoordelingen (o.a. Bligh, 1980; Hofstee, 1980) wordt geen duidelijke verschillen gevonden tussen de verschillende wegingsvormen. In het algemeen geldt echter dat weging van sterk gecorreleerde onderdelen weinig of geen gevolgen heeft op de rangordening, terwijl weging van ongecorreleerde onderdelen een groter effect sorteert (Wang \& Stanley, 1970).

In de onderwijspraktijk komt een grote variëteit aan beoordelingsmethoden voor, zij het dat zuiver globale of zuiver analytische beoordelingsmethoden zelden worden gebruikt. Dit wordt mede veroorzaakt door het feit dat het voor de beoordelaars moeilijk blijkt te zijn om alleen deelaspecten te beoordelen of slechts een ongedifferentieerd totaaloordeel te geven. Er lijkt dus een natuurlijke behoefte te bestaan voor enige mate van structurering van het beoordelingsproces.

Met betrekking tot de betrouwbaarheid blijken analytische methoden beter te zijn, hoewel ook een teveel gestructureerde beoordelingsmethode de kans op beoordelaarseffecten vergroot (Hofstee, 1983). Welke mate van differentiatie wenselijk is en hoe zich dit verhoudt met de inhoudsdeskundigheid van de beoordelaar is echter nog onduidelijk.

Onderzoek naar het beoordelen van open vragen heeft inzicht verschaft in de invloed van een groot aantal contextuele aspecten op het beoordelingsproces. In hoeverre de beoordelingsmethode als foutenbron moet worden aangemerkt is zelden onderwerp van studie geweest. In het onderhavige onderzoek is systematisch de invloed van de mate van structurering van beoordelingsmethoden en de expertise van beoordelaars op betrouwbaarheid en validiteit van beoordelingen bestudeerd. Hierbij is expliciet de invloed van verschillende wegingsmethoden betrokken, aangezien in het medische onderwijs de relevantie hiervan steeds wordt benadrukt.

De vraagstellingen die aan dit onderzoek ten grondslag lagen en de wijze waarop de vraagstellingen werden onderzocht, worden in het hiernavolgende hoofdstuk beschreven. 


\section{VRAAGSTELLINGEN EN ONDERZOEKSOPZET}

\subsection{Inleiding}

In dit hoofdstuk worden de vraagstellingen van het onderzoek uitgewerkt. Voordat de concrete vraagstellingen worden geëxpliciteerd, wordt eerst ingegaan op de context van het onderzoek. Hierbij worden de voorafgaande hoofdstukken als leidraad gebruikt. In de daaropvolgende paragrafen wordt een beschrijving gegeven van het onderzoeksdesign, waarbij de gemaakte keuzes worden toegelicht en de hypothesen worden geformuleerd.

\subsection{Plaatsbepaling van het onderzoek}

Toetsen nemen binnen het onderwijs een belangrijke plaats in. Een toets bestaat uit een set vragen en/of opdrachten, die de studenten binnen een beperkte periode moeten maken. De behaalde score op de toets wordt opgevat als een indicatie voor de mate waarin de studenten de gestelde leerdoelen hebben bereikt.

In het algemeen bestaat een schriftelijke toets uit open en/of gesloten vraagvormen. Bij een open vraagvorm moet het antwoord door de student zelf worden geformuleerd, terwijl bij een gesloten vraagvorm de student uit een aantal alternatieven de juiste moet kiezen. In hoeverre een gesloten of open vraagvorm bruikbaar is, wordt mede bepaald door de aard van het antwoord. Indien van tevoren het gewenste antwoord gedetailleerd kan worden geformuleerd, is zowel een open als een gesloten vraagvorm bruikbaar. In het geval dat het gewenste antwoord uit een reeks gegevens is opgebouwd en meerdere goede antwoorden mogelijk zijn, is alleen een open vraagvorm bruikbaar.

Voor het meten van vaardigheid in medisch probleemoplossen is in de afgelopen decennia een groot scala aan instrumenten ontwikkeld. De schriftelijke instrumenten bestaan veelal uit korte beschrijvingen van patiëntproblemen (casus), gevolgd door één of meerdere vragen. Uit de validiteits- en betrouwbaarheidsstudies blijkt dat de gebruikte instrumenten niet aan de gestelde eisen voldoen. De kwaliteit van deze instrumenten wordt voor een belangrijk deel begrensd door het gegeven dat medisch probleemoplossen sterk inhoudsafhankelijk blijkt te zijn. 
Recent ontwikkelde instrumenten proberen aan dit probleem van inhoudsspecificiteit tegemoet te komen door een groot aantal casus in één toets op te nemen. Om dit te kunnen realiseren dient het beantwoorden van de vragen bij één casus relatief weinig tijd te vergen. Dit kan worden bereikt door de vragen te beperken tot de essentiële aspecten (Bordage \& Page, 1987; De Graaff, 1989; Page et al., 1990).

In veel gevallen worden varianten van de methode van de gestructureerde open vraag gehanteerd (Knox, 1975; Feletti \& Smith, 1986). Naar aanleiding van een beschrijving van een praktijkgeval wordt een reeks korte open vragen gesteld.

Het beoordelen van de antwoorden op open vragen brengt specifieke problemen met zich mee. Op de open vragen behorende bij schriftelijke simulatie-instrumenten voor het meten van vaardigheid in medisch probleemoplossen kunnen geen eenduidig verifieerbare antwoorden worden geformuleerd. Dit betekent dat de beoordelaars een inschatting moeten maken van de kwaliteit van een gegeven antwoord. Naast factoren als de kwaliteit van het handschrift, tekstkenmerken, verwachtingspatronen van beoordelaars en voorafgaande beoordelingen vormt de subjectiviteit van beoordelaars hierbij een potentiële bron van onbetrouwbaarheid.

Voor het beoordelen van de antwoorden is kennis en inzicht in medisch probleemoplossen vereist. Deze deskundigheid is aanwezig in het hoofd van ervaren medici. Desondanks blijken de oordelen van experts regelmatig te verschillen, doordat ze niet dezelfde aspecten relevant vinden of het relatieve belang van een bepaald aspect anders inschatten. Het lijkt dan ook zinvol om voorafgaande aan de beoordeling aan een aantal experts te vragen hun expertise op papier te zetten in de vorm van een gedetailleerde beschrijving van hetgeen in het antwoord aan de orde dient te komen. Op deze wijze wordt de expertise toegankelijk en biedt het de beoordelaars houvast bij het beoordelen.

In de praktijk blijken dergelijke beoordelingsvoorschriften niet of op ad hoc basis te worden gemaakt, zonder duidelijke theoretische of empirische onderbouwing. De gebruikte beoordelingsmethoden variëren in de mate van structurering en detaillering. De gehanteerde methode heeft consequenties voor de interpretatieruimte die aan de beoordelaar wordt gegeven. Onderzoek in het taalonderwijs laat zien dat zowel een te sterke als een te zwakke structurering beoordelaarseffecten in de hand werkt en zodoende een afname in betrouwbaarheid veroorzaakt. De precieze relatie tussen de mate van structurering en het optreden van beoordelaarseffecten is echter nog onduidelijk evenals de waardering van de beoordelaars voor de verschillende beoordelingsmethoden. Welke rol de inhoudsdeskundigheid van de beoordelaar hierbij speelt is eveneens nog onbekend.

Ook met betrekking tot het toekennen van een waarde-oordeel worden verschillende methoden toegepast. Bij sommige beoordelingsmethoden telt elk onderdeel even zwaar mee in het eindoordeel, terwijl bij andere beoordelingsmethoden verschillende vormen van weging worden toegepast. Daamaast variëren de methoden in het al dan niet toekennen van strafpunten aan foutieve reacties. Het gebruik van wegingsfactoren lijkt voor een belangrijk deel voort te komen uit de behoefte om de belangrijkheid van een bepaalde respons in de beoordeling tot uitdrukking te kunnen laten komen. De invloed van een dergelijke weging op de betrouwbaarheid is echter meestal gering. Slechts in het geval dat grote verschillen in wegingsfactoren worden aangebracht tussen onathankelijke onderdelen van de beoordelingsmethode, worden verschillen in rangordening van scores gevonden (Wang \& Stanley, 1970). In tal van studies werd een combinatie van positieve en negatieve weging toegepast. Daamaast werd in deze studies de grootte van de wegingsfactoren op verschillende wijz:n bepaaid (experimenteel, op inhoudelijke gronden etc.). In hoeverre deze omstandigheden van invloed zijn op de gevonden resultaten is niet 
eenduidig vast te stellen. Gezien de grote waarde die beoordelaars aan weging hechten, lijkt onderzoek waarin verschillende vormen van weging systematisch met elkaar worden vergeleken, gewenst.

Ondanks de lange traditie in het ontwikkelen van schriftelijke simulatie-instrumenten voor het meten van vaardigheid in medisch probleemoplossen, blijken de beoordelingsproblemen slechts op beperkte schaal te zijn onderzocht. Dit onderzoek concentreert zich met name op indicatoren van medisch probleemoplossen (Donnelly et al., 1974; Donnelly, 1976; Bligh, 1980). In dergelijk onderzoek werd getracht een antwoord te vinden op de vraag: "Welke aspecten moeten in een beoordelingsmethode voor het meten van de vaardigheid in medisch probleemoplossen worden opgenomen?". De manier waarop responsen op deze indicatoren worden gecombineerd tot een score of een waardering is zelden systematisch bestudeerd. Het ontbreken van dergelijk fundamenteel onderzoek is uiterst merkwaardig, aangezien het alledaagse onderwijs alsmede het onderzoek regelmatig door optredende beoordelingsproblemen worden verstoord.

Beoordelen is en blijft mensenwerk en zal altijd in zekere mate subjectief zijn. Om de invloed van subjectiviteit te verminderen is het zinvol er na te streven dat iedere beoordelaar dezelfde aspecten in de beoordeling meeneemt. Dit kan onder andere door structurering van de beoordelingsmethode. Het is echter wel noodzakelijk een methode te ontwikkelen, die door de beoordelaars als zinvol wordt ervaren. Anders zullen de beoordelaars zich niet of slechts gedeeltelijk aan de beoordelingsmethode houden, waardoor de subjectiviteit van de beoordeling zal toenemen.

In het onderhavige onderzoek is aan bovenstaande beoordelingsproblematiek aandacht besteed. Met name de invloed van zowel structurering van beoordelingsmethoden, de deskundigheid van beoordelaars als weging op betrouwbaarheid en validiteit is bestudeerd. Daamaast is aandacht besteed aan de waardering van de beoordelaars voor de beoordelingsmethoden.

De precieze vraagstellingen en de globale onderzoeksopzet komen in de volgende paragrafen aan de orde.

\subsection{Vraagstellingen van het onderzoek}

De vraagstellingen die aan het onderzoek ten grondslag lagen. kunnen in de volgende vier categorieën worden onderverdeeld: validiteit, generaliseerbaarheidsanalyses, weging en waardering van de beoordelingsmethoden. In deze paragraaf worden de vraagstellingen en de deelvraagstellingen per categorie beschreven.

\section{Validiteit}

Vraagstelling 1 .

Welke invloed heeft de structurering van beoordelingsmethoden op de validiteit van gegeven beoordelingen voor antwoorden op een schriftelijk simulatie-instrument voor het meten van de vaardigheid in medisch probleemoplossen, dat gebruik maakt van korte antwoordvragen? 
Vraagstelling 2.

Welke invloed heeft de deskundigheid c.q. medische expertise van de beoordelaar op de validiteit en in hoeverre wordt de relatie tussen medische expertise en de validiteit beïnvloed door de mate van structurering van de beoordelingsmethode?

Deze vraagstelling valt in twee deelvragen uiteen:

2a. Wat is de invloed van medische expertise van de beoordelaars op de validiteit van de meting?

2b. Welke invloed heeft de interactie tussen de medische expertise van de beoordelaars en de mate van structurering van de beoordelingsmethode op de validiteit van de meting?

\section{Generaliseerbaarheidsanalyses}

Vraagstelling 3.

Wat is de invloed van de mate van structurering van de beoordelingsmethode op de betrouwbaarheid van een schriftelijk simulatie-instrument voor het meten van de vaardigheid in medisch probleemoplossen, dat gebruik maakt van korte antwoordvragen?

Deze vraagstelling valt in de volgende deelvragen uiteen:

3a. Welke invloed heeft de mate van structurering van de beoordelingsmethode op de mate waarin beoordelaarseffecten bijdragen aan de totale variantie van een meting (over alle vragen heen), vergeleken met andere variantiebronnen.

3b. Welke invloed heeft structurering van de beoordelingsmethode op de interbeoordelaarsbetrouwbaarheid?

Vraagstelling 4 .

Welke invloed heeft de deskundigheid c.q. medische expertise van de beoordelaar op de betrouwbaarheid en in hoeverre wordt de relatie tussen medische expertise en betrouwbaarheid beïnvloed door de mate van structurering van de beoordelingsmethode?

Deze vraagstelling bestaat eveneens uit een aantal deelvragen.

4a. Wat is de invloed van medische expertise van de beoordelaars op de interbeoordelaarsbetrouwbaarheid?

4b. Wat is de invloed van medische expertise van beoordelaars op de totale betrouwbaarheid van de meting?

4c. Wat is de invloed van de interactie tussen de medische expertise van de beoordelaars en de mate van structurering van de beoordelingsmethode op de interbeoorde- 
laarsbetrouwbaarheid?

4d. Welke invloed heeft de interactie tussen de medische expertise van de beoordelaars en de mate van structurering van de beoordelingsmethode op de totale betrouwbaarheid van de meting?

\section{Weging}

Vraagstelling 5.

Welke invloed hebben verschillende methoden van weging van onderdelen van gestructureerde beoordelingsmethoden op de validiteit van de beoordelingsmethoden?

\section{Waardering van de beoordelingsmethoden}

Vraagstelling 6.

Wat vinden de beoordelaars van de mate van structurering van de verschillende beoordelingsmethoden?

Deze vraagstelling wordt opgesplitst in de volgende deelvragen:

6a. Welke mate van structurering van de beoordelingsmethode wordt door de beoordelaars als het prettigst ervaren?

6b. Hangt de voorkeur voor een bepaalde mate van structurering van de beoordelingsmethode samen met de medische expertise van de beoordelaars?

Globaal hebben de vraagstellingen betrekking op enerzijds de invloed van de mate van structurering en anderzijds de methode van weging op validiteit, betrouwbaarheid en acceptabiliteit van beoordelingsmethoden.

De gehanteerde benaderingswijze voor het schatten van betrouwbaarheid heert echter consequenties voor de aspecten die al dan niet kunnen worden bestudeerd. In de volgende paragraaf worden de belangrijkste benaderingswijzen voor het schatten van betrouwbaarheid beschreven, waarna de keuze voor een schattingsmethode wordt gemaakt.

\subsection{Methoden voor het schatten van de betrouwbaarheid}

In de literatuur worden verschillende manieren beschreven waarop betrouwbaarheid kan worden geschat (o.a. Ghiselli, 1964; Meerling, 1981a, 1981b; De Gruijter \& Van der Kamp, 1984). Historisch gezien zijn deze manieren terug te leiden tot drie "hoofd" theorieën, te weten: de klassieke testtheorie, de generaliseerbaarheidstheorie en de itemrespons theorie. Deze theorieen worden in deze paragraaf kort beschreven. 


\subsubsection{Klassieke testtheorie}

In de klassieke testtheorie wordt een behaalde toetsscore opgevat als een lineaire additieve functie van de ware score en een foutscore (=toevalsscore).

In formule:

$$
X_{T}=X_{W}+E
$$

$$
\begin{aligned}
& X_{T}=\text { de toetsscore } \\
& X_{\mathrm{w}}=\text { de ware score } \\
& E=\text { de toevallige score }(=\text { meetfout }=\text { error })
\end{aligned}
$$

Stel het theoretische geval dat bij een student een groot aantal keren dezelfde toets onder steeds dezelfde condities wordt afgenomen, zonder dat bij de student een leereffect optreedt. De behaalde scores zijn dan volgens een normaalverdeling om het gemiddelde verdeeld. De gemiddelde score is dan gelijk aan de ware score voor de student. Voor elke afzonderlijk behaalde score geldt dan dat het verschil tussen de desbetreffende score en het gemiddelde van de scores gelijk is aan de toevalsscore. Deze afstand tussen de score en het gemiddelde c.q. ware score wordt meetfout (error of measurement) genoemd. Hoe groter de spreiding van de scores rondom het gemiddelde, des te meer onbetrouwbaar is de toets. In de praktijk is echter de standaardmeetfout van één enkel persoon niet bekend, maar wordt aangenomen dat deze gelijk is voor alle studenten die een toets hebben gemaakt.

Uit bovenstaande volgt een aantal belangrijke assumpties van de klassieke testtheorie. Allereerst wordt aangenomen dat de verdeling van de toevalsscores zodanig is dat het gemiddelde van de toevalsscores gelijk aan nul is:

$$
M_{E}=0
$$

Hieruit vloeit voort dat het gemiddelde van de behaalde scores gelijk is aan de ware score:

$$
M_{X}=M_{X_{w}}
$$

Daarnaast wordt er van uitgegaan dat (1) er geen enkele afhankelijkheidsrelatie bestaat tussen de toevalsscores en de ware score, (2) er geen correlatie bestaat tussen de meetfouten op de ene meting en de ware score op een andere meting en (3) er geen correlatie bestaat tussen de meetfouten van verschillende toetsen.

Analoog aan bovenstaande redenering geldt dat de waargenomen variantie van de scores is op te splitsen in een "ware variantie" en een "toevalsvariantie". 
In formule:

$$
S_{T}^{2}=S_{W}^{2}+S_{E}^{2}
$$

$$
\begin{aligned}
& S_{T}^{2}=\text { totale variantie } \\
& S_{W}^{2}=\text { ware variantie } \\
& S_{E}^{2}=\text { toevalsvariantie }
\end{aligned}
$$

De betrouwbaarheid is dan gelijk aan de proportie ware variantie van de totale waargenomen variantie, waarbij de ware variantie het verschil is tussen de totale waargenomen variantie en de error of fouten-variantie (Ghiselli, 1964, Meerling, 1981a, 1981b; Swanson et. al., 1987).

In formule:

$$
B=\frac{S_{W}^{2}}{S_{T}^{2}}=\frac{S_{T}^{2}-S_{E}^{2}}{S_{T}^{2}}=1-\frac{S_{E}^{2}}{S_{T}^{2}}
$$

$$
\begin{aligned}
& B=\text { betrouwbaarheid } \\
& S_{T}^{2}=\text { totale variantie } \\
& S_{W}^{2}=\text { ware variantie } \\
& S_{E}^{2}=\text { toevalsvariantie }
\end{aligned}
$$

Uit de bovenstaande vergelijking blijkt dat de aldus gedefinieerde betrouwbaarheid inderdaad 1 is als de toevalsvariantie gelijk aan 0 is.

In de klassieke testtheorie speelt bij het schatten van betrouwbaarheid het concept van parallelle metingen een belangrijke rol (Nunnally, 1967). Hierbij wordt een onderscheid gemaakt tussen de methoden van herhaalde metingen enerzijds en de bewerkingen van eenmalige metingen anderzijds (Drenth, 1984).

Bij de methode van herhaalde metingen kunnen twee vormen worden onderscheiden, te weten: (1) één test wordt twee of meer malen aan een persoon voorgelegd, (2) een tweede test (met een gelijke ware variantie als de eerste test) wordt aan de persoon aangeboden. Bij beide werkwijzen vormt de mate waarin de verschillende scores met elkaar overeenkomen (correlatie) de schatting van de betrouwbaarheid.

Ook als slechts één meting per persoon is uitgevoerd, zijn verschillende schattingsmethoden mogelijk. Een eenvoudige schatting van de betrouwbaarheid kan worden bereikt door de test in tweeën te delen en de correlatie tussen beide delen te bepaien (split-half methode). Verder doorgevoerd kan elk item als aparte test worden opgevat. Met deze methode wordt de interne consistentie van de toets bepaald. Een veel gehanteerde betrouwbaarheidsindex voor de homogeniteit van een toets is coëfficiënt alfa, 
gedefinieerd als (Cronbach, 1964):

$$
r_{k k}=\frac{k}{(k-1)}\left(1-\frac{\sum_{i=1}^{i=\infty} s_{i}^{2}}{s^{2}}\right)
$$

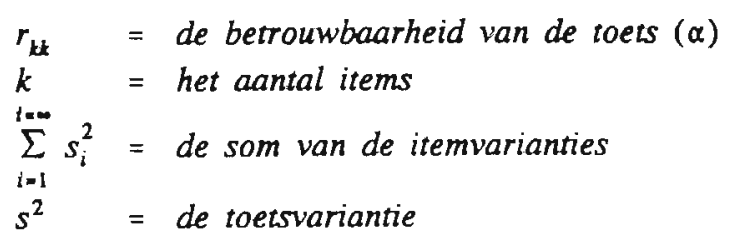

Bij open vragen speelt, naast de consistentie van items, ook de overeenstemming tussen beoordelaars een belangrijke rol bij de nauwkeurigheid van beoordelingen. De mate waarin beoordelaars overeenstemmen wordt uitgedrukt in de interbeoordelaarsbetrouwbaarheid. Binnen de klassieke testtheorie bestaat geen specifieke index voor het schatten van interbeoordelaarsbetrouwbaarheid. maar wordt afhankelijk van de gehanteerde meetprocedure een bepaalde index gekozen (percentage overeenstemming, kappa, correlaties etc.) (Harman, 1977; Asendorf \& Wallbott, 1979; House et al.. 1981; Maxwell, 1983).

Met behulp van de klassieke testheorie kunnen dus verschillende betrouwbaarheidsindices onafhankelijk van elkaar worden geschat. Welke indices kunnen worden gebruikt, is afhankelijk van de aard van het meetinstrument, de eigenschap die wordt gemeten en de gehanteerde procedure. Voordat een bepaalde betrouwbaarheidsindex kan worden geinterpreteerd, dient eerst de vraag te worden gesteld wat bij de gehanteerde procedure tot de ware- en wat tot de niet-ware-variantie behoort. Tevens moet rekening worden gehouden met het feit dat de gevonden resultaten steekproefafhankelijk zijn, hetgeen betekent dat de gegevens afhankelijk zijn van de grootte en de aard van de getrokken steekproef. Een derde tekortkoming van de klassieke testtheorie vormt het feit dat zowel binnen de ware-als de error-variantie de relatieve invloed van verschillende factoren niet kan worden geëxpliciteerd.

Ondanks deze "tekortkomingen" werd en wordt de klassieke testheorie frequent gebruikt. Deze populariteit is voor een belangrijk deel het gevolg van de relatief simpele uitgangspunten en de praktische bruikbaarheid.

Een methode die aan een aantal bezwaren tegen de klassieke testtheorie tegemoetkomt is de generaliseerbaarheidstheorie.

\subsubsection{Generaliseerbaarheidstheorie}

Generaliscerbaarheidstheorie kan worden opgevat als een uitbreiding van de klassieke testtheorie, waarbij wordt uitgegaan van een meer gedetailleerde decompositie van de geobserveerde score. Aangezien diverse foutenbronnen in de betrouwbaarheidsanalyse kunnen worden betrokken, kan op basis van de in het onderzoek betrokken factoren 
("facets") een aantal vormen van betrouwbaarheid gelijktijdig en nauwkeuriger worden onderzocht (Cronbach et. al., 1972; Mitchell, 1979; Brennan, 1983; De Gruijter \& Van der Kamp, 1984). Welke factoren in de betrouwbaarheidsanalyse worden betrokken en welke betrouwbaarheidsindices worden geschat, is afhankelijk van de vraagstellingen van het onderzoek. Hierdoor wordt de vraag naar de betrouwbaarheid eigenlijk een vraag naar de generaliseerbaarheid van de gegevens, waarbij expliciet moet worden aangegeven welke generalisatiewaarde men aan de gegevens wil toekennen (Cronbach et al., 1972; Brennan, 1983).

In de generaliseerbaarheidstheorie worden betrouwbaarheidsstudies uitgevoerd met behulp van zogenaamde generaliseerbaarheids- en decision-studies.

\subsubsection{Generaliseerbaarheidsstudie}

Generaliseerbaarheidsstudies (G-studies) zijn onderzoekingen waarin de onderzoeker is geïnteresseerd in de bijdrage van de verschillende facetten en de interacties tussen de facetten op de totale variantie. Hiertoe is het noodzakelijk dat alle facetten worden geëxpliciteerd en het aantal waarnemingen ("conditions") per facet wordt vastgesteld. De totale set van facetten en condities vormt de "universe of admissible observations" (Cronbach et al., 1972; Brennan \& Kane, 1979; Brennan, 1983).

Nadat deze "universe of admissible observations" is bepaald, wordt een variantie-analyse (ANOVA) uitgevoerd. Op basis van deze ANOVA worden de verschillende variantiecomponenten geschat, waardoor een overzicht wordt verkregen van de relatieve bijdrage van de verschillende facetten.

Welke variantiebronnen kunnen worden onderscheiden, hangt af van het gehanteerde design. Indien voor alle facetten twee of meer observaties beschikbaar zijn, kan voor elk facet een variantiecomponent worden geschat. In het geval dat voor een facet slechts onafhankelijke observaties beschikbaar zijn binnen een ander facet, kan voor dit facet geen aparte variantiecomponent worden geschat. De bijbehorende variantiecomponent zit dan in de andere bronnen verweven.

In het eerste geval is er sprake van een volledig gekruist design, terwijl de tweede situatie een voorbeeld van een genest design is (Cronbach et al., 1972; Brennan \& Kane, 1979; Brennan, 1983).

Indien in de G-studie voor eik facet wordt uitgegaan van een willekeurige steekproef van condities uit een groter domein van condities, wordt het onderliggende model, in termen van variantie-analyse, als random beschouwd. Als de gekozen condities voor elk facet gelijk zijn aan alle mogelijke condities, wordt het model fixed genoemd. Een design waarin beide situaties voorkomen, wordt een mixed model genoemd (Cronbach et al., 1972; Van der Kamp, 1976; Brennan \& Kane, 1979; Brennan, 1983).

\subsubsection{Decision-studie}

Decision-studies (D-studies) zijn onderzoekingen, waarin de verschillende betrouwbaarheidsindices worden geschat aan de hand van de geschatte variantiecomponenten uit de Gstudie en waarin wordt gespecificeerd welke generalisatiewaarde de onderzoeker aan de gegevens wenst te geven. Bij het berekenen van de indices wordt net als in de klassieke testtheorie aangenomen, dat de waargenomen score is opgebouwd uit een ware score en 
een toevalsscore, waarbij de toevalsscore uit verschillende foutenbronnen kan bestaan. Analoog aan de klassieke testtheorie wordt betrouwbaarheid gezien als de verhouding tussen de gewenste (ware) variantie (universum score) en de geobserveerde variantie. Welke facetten tot de ware variantie behoren en welke facetten als foutenbron worden gezien, hangt af van het gekozen design van de G- en D-studie en de door de onderzoeker gewenste uitspraken.

$$
B=\frac{S_{\text {ware }}^{2}}{S_{\text {geobserveerde }}^{2}}
$$

$$
\begin{array}{ll}
B & =\text { betrouwbaarheid } \\
S_{\text {ware }}^{2} & =\text { ware variantie } \\
S_{\text {geobserverde }}^{2} & =\text { geobserveerde variantie }
\end{array}
$$

Het vaststellen van het design vormt dus een vast en cruciaal onderdeel bij de definiëring van de D-studie. Evenals bij de G-studie kan bij de D-studie een gekruist of genest design worden gehanteerd.

In een D-studie kunnen maximaal alle facetten, waarvan in de G-studie variantiecomponenten zijn geschat, worden betrokken. Het is echter ook mogelijk om slechts enkele facetten uit de G-studie in een D-studie te betrekken. Naast het definiëren van het design en het vaststellen van de "objects of measurement" (de facetten die tot de "ware variantie" behoren), vormt ook de specificatie van het aantal waarnemingen voor elk facet een vast onderdeel bij het opstellen van een D-studie. Het aantal waamemingen in een D-studie behoeft niet gelijk te zijn aan het aantal waamemingen in de G-studie. Integendeel, door het aantal te veranderen kan de invloed van het aantal waamemingen op de betrouwbaarheid worden onderzocht.

Het gehanteerde design en het onderliggende model voor de D-studie hebben dus gevolgen voor de uitspraken die op basis van de D-studie kunnen worden gedaan. Het is dan ook van belang dat van tevoren wordt bepaald welke informatie de D-studie moet opleveren en naar welk universum wordt gegeneraliseerd.

Voor elke D-studie worden variantie-componenten geschat voor de universum score en voor de error-termen en worden betrouwbaarheidsindices geschat in de vorm van generaliseerbaarheidscoëfficiënten. De wijze waarop de componenten worden geschat, hangt echter af van het gehanteerde design. De hierna volgende beschrijving beperkt zich dan ook tot de betekenis van deze aspecten binnen de generaliseerbaarheidstheorie. Voor meer gedetailleerde informatie wordt verwezen naar Cronbach et al. (1972) en Brennan (1983).

Een universum score is de gemiddelde score voor het "object of measurement" binnen het universum waarnaar wordt gegeneraliseerd. Deze score is vergelijkbaar met de ware score in de klassieke testtheorie. De variantie van deze scores wordt de "universe score variance" genoemd. Deze variantie is vergelijkbaar met de ware variantie in de klassieke testtheorie. Wel dient te worden opgemerkt dat in de generaliseerbaarheidstheorie, in tegenstelling tot de klassieke testtheorie, meer dan één "universe score variance" kan bestaan, aangezien de "universe score variance" afhankelijk is van de gekozen "universe 
of generalization". Of wel, de bepaling van de "universe score variance" is afhankelijk van de gewenste uitspraken die de onderzoeker op basis van de resultaten van de meting wil doen.

In de generaliseerbaarheidstheorie worden twee vormen van error-variantie onderscheiden: absolute en relatieve error-variantie. De absolute error-variantie $(\Delta)$ is de variantie van het verschil tussen de geobserveerde score en de universum score. De relatieve errorvariantie $(\delta)$ is de variantie van het verschil tussen de geobserveerde en de universum score, genormeerd naar het gemiddelde van de geobserveerde en universum score binnen de totale populatie.

Een generaliseerbaarheidscoëfficiënt kan worden gehanteerd als een maat voor betrouwbaarheid. Deze index wordt gedefinieerd als de ratio tussen de variantie van de universum score en de variantie van de verwachte score.

In formule:

$$
\text { Generaliseerbaarheidscoëfficiënt }=\frac{S_{\text {uriversum }}^{2}}{S_{\text {geobservecrde }}^{2}}
$$

Concluderend kan worden gesteld dat de variantiecomponenten de kern van de generaliseerbaarheidstheorie vormen. Op basis van deze gegevens worden de verdere berekeningen uitgevoerd. De variantiecomponenten bieden overigens een genuanceerder beeld dan de betrouwbaarheidsindices, aangezien de relatieve bijdrage van de verschillende variantiebronnen hierin expliciet tot uitdrukking komt. De berekende indices kunnen worden opgevat als een numerieke weergave en exemplarisch voorbeeld van hetgeen op basis van de variantiecomponenten kan worden voorspeld (Cronbach et. al., 1972; Mitchell, 1979; Thorndike, 1982; Brennan, 1983).

Met behulp van de generaliseerbaarheidstheorie is het mogelijk de invloed van verschillende factoren in relatie tot elkaar op een meting te bestuderen. Tevens biedt de generaliseerbaarheidstheorie de mogelijkheid om de invloed van het aantal condities en het aantal waarnemingen binnen condities op betrouwbaarheid, te onderzoeken. Hierdoor wordt gedeeltelijk tegemoetgekomen aan het bezwaar dat wordt aangevoerd ten aanzien van de klassieke testtheorie (Brennan, 1983).

Het feit dat geen algemeen geldende theorie wordt ontwikkeld met betrekking tot de relatie tussen de factoren die de score bepalen, maar dat wordt getracht empirische gegevens in een lineair additief model weer te geven, vormt het belangrijkste bezwaar dat tegen zowel de klassieke testtheorie als de generaliseerbaarheidstheorie wordt aangevoerd. Een benaderingswijze die aan dit bezwaar tegemoet komt, is de item-respons theorie.

\subsubsection{Item-respons theorie}

Uitgangspunt van de item-respons theorie (IRT) is, dat personen kunnen worden geordend op één onderliggende dimensie, continuüm genoemd. De plaats die een bepaald persoon op dit continuüm inneemt geeft aan in welke mate die persoon de desbetreffende eigenschap bezit (Hambleton \& Cook, 1977; Meerling, 1981a, 1981b; De Gruijter \& Van der Kamp, 1984). Aangezien de schaalwaarde van een persoon op dit continuüm niet direct 
waarneembaar is, moet de veronderstelde latente trek worden geoperationaliseerd in observeerbare manifeste kenmerken. Om dit te bereiken wordt een set items samengesteld die representatief wordt geacht voor de onderliggende capaciteit. Het verband tussen de capaciteit van een persoon en de kans op het goed beantwoorden van een item wordt uitgedrukt in een wiskundige functie, de zogenaamde item-karakteristieke curve (Hambleton \& Cook, 1977; Meerling, 1981a, 1981b; De Gruijter \& Van der Kamp; 1984).

De eerste item-respons theorie werd geformuleerd door Guttman (1950). In deze theorie voor dichotome items werd aangenomen dat een persoon wiens capaciteit onder de benodigde capaciteit voor het goed hebben van het item ligt, dit item per definitie foutief beantwoordt. Elke persoon waarvan de capaciteit boven deze grenswaarde ligt, beantwoordt het desbetreffende item goed. De bijbehorende item-karakteristieke curve heeft een vorm zoals weergegeven in figuur 3.1. Op de horizontale as staat de latente trek uitgezet, terwijl op de verticale as de kans op het goed beantwoorden van het item is uitgezet.

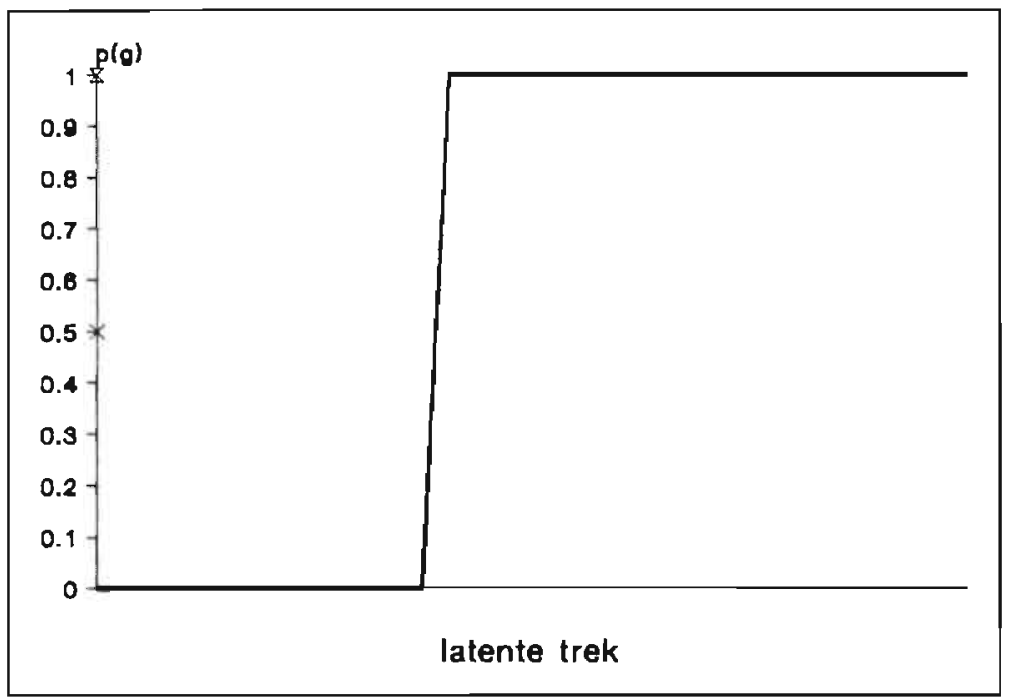

Figuur 3.1: Item-karakteristieke curve behorende bij het Guttman-model.

Volgens de theorie van Guttman is het niet mogelijk dat een persoon een gemakkelijk item foutief beantwoordt en een moeilijk item goed heeft. In de praktijk wordt veelal niet aan deze vooronderstelling voldaan. Mokken (1970) ontwikkelde een model voor dichotome items op ordinaal schaalniveau, dat aan bovenstaand probleem tegemoetkomt. In dit model wordt uitgegaan van monotoon stijgende item-karakteristieke curven, zodat de kans op het goed hebben van een item toeneemt naarmate de capaciteit van een persoon groter is. Bovendien geldt bij dit model dat de kans op het goed hebben van een makkelijk item groter of gelijk is aan de kans op het goed hebben van een moeilijker item. Dit impliceert dat de item-karakteristieke curven van de verschillende items elkaar niet mogen kruisen. Een voorbeeld van enkele item-karakteristieke curven die voldoen aan de eisen van het Mokken-model zijn weergegeven in figuur 3.2. Op de horizontale as staat de latente trek uitgezet, terwijl op de verticale as de kans op het goed beantwoorden van het item is uitgezet. 
Zowel het Guttman- als het Mokken-model biedt de mogelijkheid personen te rangordenen op een onderliggende latente trek. Beide modellen gaan echter uit van het ordinale schaalniveau. Dit in tegenstelling tot enkele andere item-respons theorieën, die uitgaan van interval- of ratioschaalniveau, zoals de logistische en normaal ogief modellen (Hambleton et al., 1979; Meerling, 1981a, 1981b; De Gruijter \& Van der Kamp, 1984).

De normaal ogief modellen en de logistische modellen verschillen in principe niet veel van elkaar, aangezien de logistische en de normale verdelingsfuncties veel op elkaar lijken. In de praktijk worden de normaal ogief modellen echter minder frequent toegepast dan de logistische modellen. Dit wordt mede veroorzaakt door het feit dat bij eerstgenoemde modellen meer complexe berekeningen moeten worden uitgevoerd.

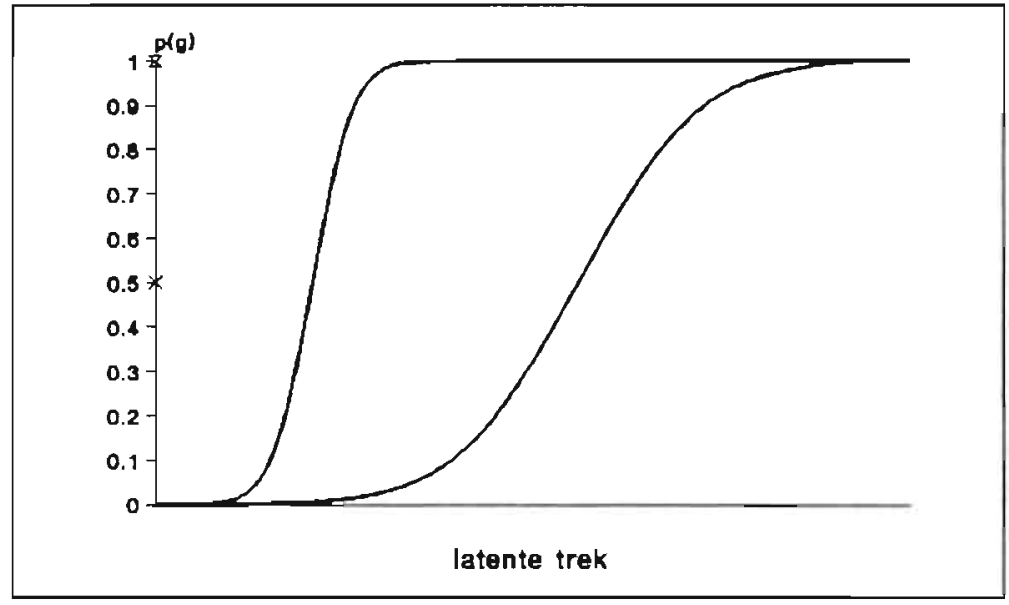

Figuur 3.2: Item-karakteristieke curve behorende bij het Mokken-model.

Aan de item-karakteristieke curve van de logistische modellen wordt een aantal eisen gesteld. Allereerst moet de item-karakteristieke curve door middel van een beperkt aantal parameters kunnen worden beschreven. Tevens mag de item-karakteristieke curve geen knikken vertonen. Tenslotte mag voor geen enkele capaciteit $(\theta)$ de kans op het goed of fout hebben van een item gelijk aan 0 of 1 zijn. De basiscurve behorende bij de logistische modellen wordt weergegeven in figuur 3.3.

Op de horizontale as staat de latente trek uitgezet, terwijl op de verticale as de kans op het goed beantwoorden van het item is uitgezet.

De plaats van de item-karakteristieke curve op het continuüm wordt bepaald door de moeilijkheidsgraad van het item $(\delta)$ : hoe moeilijker het item des te verder naar rechts ligt de curve op het continuum. De steilheid van de curve geeft het discriminerend vermogen $(\alpha)$ van het item aan; hoe steiler de curve des te beter kan het item het verschil tussen personen met een andere waarde op het continuüm onderscheiden (Rasch, 1960; Wright et al., 1979; Meerling, 1981a, 1981b; Wright et. al., 1982; De Gruijter \& Van der Kamp, 1984). 


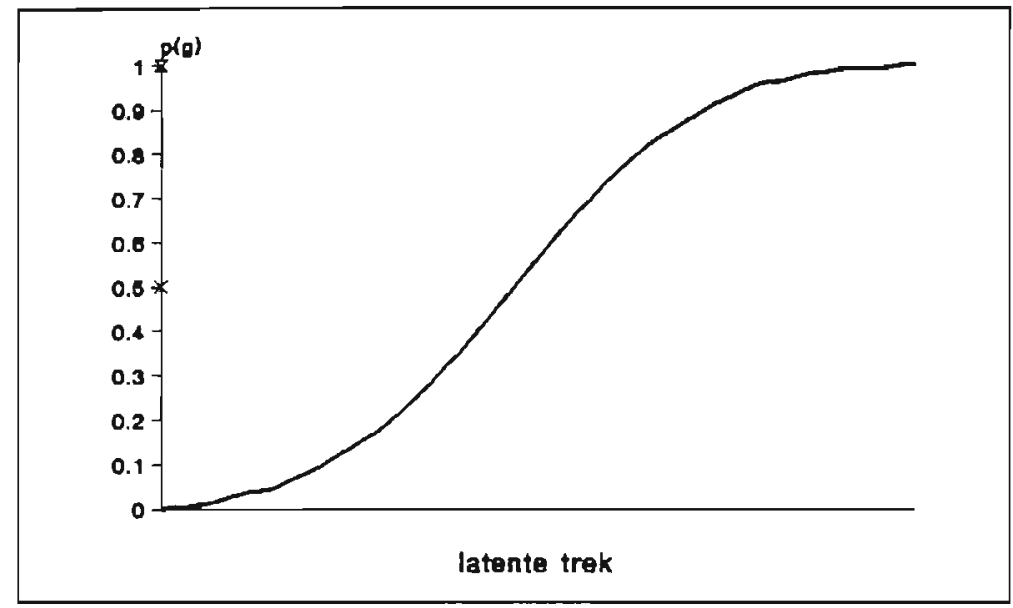

Figuur 3.3: Item-karakteristieke curve behorende bij de logistische modellen.

Globaal kunnen een zestal logistische modellen worden onderscheiden (Hambleton et. al., 1979; Meerling, 1981a, 1981b; De Gruijter \& Van der Kamp 1984):

(1) én parameter logistisch model (Rasch model)

(2) twee parameter logistisch model (Birnbaum model)

(3) drie parameter logistisch model

(4) normal response model

(5) graded response model

(6) continuous response model

Het eén parameter logistisch model wordt ook wel met de naam Rasch model aangeduid. In het Rasch model wordt de item-karakteristieke curve door de volgende functie weergegeven (Rasch, 1960; Hambleton et al., 1977; Wright et al., 1979; Meerling, 1981a, 1981b; Wright et al., 1982; De Gruijter \& Van der Kamp, 1984):

$$
p_{g}(\Theta)=\frac{e^{(\theta-8)}}{1+e^{(\Theta-\delta)}}
$$

Deze functie bevat slechts één parameter namelijk $\delta$. Deze parameter staat voor de moeilijkheidsgraad van elk item.

In het Rasch model wordt aangenomen dat het discriminerend vermogen van alle items even groot is. Dit heeft als gevolg dat alle item-karakteristieke curven in een figuur via een lineaire transformatie tot één curve zijn terug te voeren.

In het twee parameter logistisch model, ook wel Birnbaum model genoemd, moeten twee parameters vooraf worden bepaald: (1) de moeilijkheidsgraad van het item $(\delta)$ en $(2)$ het discriminerend vernıgen van hel item $(\alpha)$. De bijbehorende item-karakteristieke functie 
ziet er als volgt uit (Bimbaum, 1968, 1969; Hambleton et al., 1977; Meerling, 1981a, 1981b; De Gruijter \& Van der Kamp, 1984):

$$
p_{8}(\theta)=\frac{e^{\alpha(\theta-\delta)}}{1+e^{\alpha(\theta-\delta)}}
$$

Dit model wordt echter minder frequent gebruikt dan het hiervoor beschreven Rasch model, aangezien het bepalen van de twee parameters nog meer en moeilijkere statistische en numerieke bewerkingen vraagt en een nog grotere steekproef proefpersonen vereist (Hambleton et al., 1977; Meerling, 1981a, 1981b; De Gruijter \& Van der Kamp, 1984).

Het drie parameter logistisch model is een verdere uitbreiding van het Birnbaum model met de parameter $\tau$. Deze parameter bepaalt de horizontale asymptoot in de grafiek en geeft de kans weer dat een persoon met een lage capaciteit een item goed beantwoordt. Deze $\tau$ parameter wordt ook wel "gok parameter" genoemd. De item-karakteristieke functie van het drie parameter logistisch model kent de volgende vorm (Lord \& Novick. 1968; Lord, 1974; Hambleton et al., 1977; Meerling, 1981a, 1981b; De Gruijter \& Van der Kamp, 1984):

$$
p_{g}(\Theta)=\tau+(1-\tau) \frac{e^{\alpha(\theta-8)}}{1+e^{\alpha(\theta-8)}}
$$

Evenals bij het Bimbaum model vergt het schatten van de parameters ingewikkelde statistische en numerieke bewerkingen en is een grote steekproef proefpersonen vereist. Daarom wordt ook dit model minder frequent toegepast (Lord \& Novick, 1968; Hambleton et al., 1977; Meerling, 1981a, 1981b; De Gruijter \& Van der Kamp, 1984).

De hiervoor beschreven één, twee en drie parameter modellen kunnen alleen bij dichotome items worden toegepast. Het normal response model (Bock, 1972; Samejima, 1972) biedt echter een oplossing voor deze beperking. In dit model kunnen items met een onbeperkt aantal alternatieven ("options") op een soortgelijke wijze als in de hiervoor beschreven modellen worden afgebeeld. In plaats van een item-karakteristieke curve wordt in dit model een "item option characteristic curve" bepaald. Dit betekent dat voor elk alternatief (option) een curve moet worden bepaald. De curve van het goede alternatief is monotoon stijgend, terwijl de curven van de foute alternatieven monotoon dalend zijn. De steilheid van de monotoon dalende curven hoeven echter niet gelijk te zijn daar de steilheid afhangt van hoe goed de foute altematieven tussen personen met verschillende capaciteit discrimineren. De kans dat een persoon een bepaald alternatief kiest, wordt eveneens uitgedrukt in een waarschijnlijkheidsfunctie (Samejima, 1972; Bock, 1972).

In het graded response model wordt aangenomen dat de verschillende alternatieven kunnen worden geordend naar de mate waarin deze de (latente) capaciteit weergeven (Samejima, 1969). Als het aantal alternatieven oneindig groot wordt, levert het continuous response model de beste schattingen voor de capaciteit op (Samejima, 1973, 1974).

Samenvattend kan worden gesteld, dat in de item-respons theorie het item centraal staat. Over een item wordt een theorie ontwikkeld (bijv. met betrekking tot de kans op het goed beantwoorden van het item), die vervolgens in de praktijk wordt getoetst. In het geval dat een dergelijke theorie voor de items geldt, worden deze items als een meetlat gebruikt om 
betrouwbare uitspraken te doen over een bepaalde capaciteit van een persoon.

Het voordeel van de item-respons theorie is, dat wordt getracht een steekproef-onafhankelijke theorie op te zetten. Door de goede wiskundige eigenschappen wordt de item-respons theorie een "sterkere" theorie genoemd dan de klassieke testtheorie en de generaliseerbaarheidstheorie. De wiskundige eisen die door de modellen worden gesteld, zijn echter dermate hoog, dat de modellen in de praktijk vaak moeilijk bruikbaar zijn. Zo vergt het schatten van de verschillende parameters uitgebreide en ingewikkelde berekeningen. Tevens blijkt vaak in de praktijk slechts een beperkt aantal items aan de gestelde eisen te voldoen. Een andere praktische tekortkoming van de item-respons theorie is dat, evenals in de klassieke testtheorie, een minder gedifferentieerd inzicht wordt verkregen in de invloed van diverse foutenbronnen op de betrouwbaarheid van een meting.

\subsubsection{De keuze van een benaderingswijze voor het schatten van betrouwbaar- heid}

Uit de vorige paragrafen blijkt dat de drie benaderingswijzen voor het schatten van betrouwbaarheid duidelijk van elkaar verschillen. Het uitgangspunt van zowel de klassieke testtheorie als de generaliseerbaarheidstheorie is de empirische gegevens weer te geven in een lineair additief model. In beide benaderingswijzen wordt de geobserveerde score opgedeeld in een ware score en een toevalsscore. In tegenstelling tot de klassieke testheorie biedt de generaliseerbaarheidstheorie de mogelijkheid meerdere foutenbronnen te onderscheiden. Hierdoor wordt het mogelijk de relatieve invloed van verschillende foutenbronnen op de totale variantie te bestuderen. Beide benaderingswijzen zijn geschikt om data systematisch te analyseren en te beschrijven, maar hebben niet tot doel een algemeen geldende meetlat te ontwikkelen.

Het ontwikkelen van een meetlat vormt daarentegen het uitgangspunt van de item-respons theorie. Met behulp van deze theorie kunnen modellen worden ontwikkeld, waarmee de relatie tussen de capaciteit van een persoon en de kans op het goed beantwoorden van een vraag wordt vastgelegd. Hiermee wordt het mogelijk een meetlat te ontwikkelen, op basis waarvan betrouwbare uitspraken kunnen worden gedaan over capaciteiten van personen.

Het onderhavige onderzoek had tot doel inzicht te verschaffen in de beoordelingsproblematiek bij open vraagvormen. Hoewel het onderzoek is uitgevoerd in het competentiedomein van medisch probleemoplossen en adequate schriftelijke simulatie-instrumenten voor het meten van vaardigheid in medisch probleemoplossen ontbreken, had het onderzoek niet tot doel een dergelijk instrument te ontwikkelen. Gezien de uitgangspunten van de item-respons theorie kon worden geconcludeerd, dat deze benaderingswijze voor het onderzoek niet de meest geschikte zou zijn.

In het onderzoek ging de interesse met name uit naar de invloed van structurering van beoordelingsmethoden, de expertise van beoordelaars en weging op betrouwbaarheid en validiteit van beoordelingen. Om de invloed van verschillende factoren (beoordelingsmethoden, beoordelaars, items en personen) op betrouwbaarheid te kunnen bestuderen, was het noodzakelijk om de invloed van de verschillende variantiebronnen op de totale variantie te kunnen schatten. Van de twee resterende benaderingswijzen bood alleen de generaliseerbaarheidstheorie de mogelijkheid dergelijke schattingen te maken. Vandaar dat voor deze theorie voor het schatten van betrouwbaarheid werd gekozen.

Om de vraagstellingen van het onderzoek te kunnen beantwoorden werd, uitgaande van de 
mogelijkheden van de generaliseerbaarheidstheorie, een onderzoeksdesign ontwikkeld. In de volgende paragraaf wordt een globale beschrijving van het design gegeven. Hierin komen de aspecten van het design aan de orde die essentieel zijn voor het kunnen beschrijven van de verwachtingen en de hypothesen die aan het onderzoek ten grondslag lagen. Een meer gedetailleerde uiteenzetting volgt in hoofdstuk 4 en hoofdstuk 5 .

\subsection{Operationalisering van de vraagstelling}

Om de vraagstellingen te kunnen beantwoorden, werden voor het onderzoek een casustoets en de bijbehorende beoordelingsmethoden ontwikkeld. De toets bestond uit acht casus, die inhoudelijk waren gericht op de huisartspraktijk. Bij elke casus werden cén, twee of drie korte antwoordvragen geformuleerd.

Voor het beoordelen van de antwoorden op de vragen werd een viertal beoordelingsmethoden ontwikkeld, die verschilden in mate van structurering. Bij de minst gestructureerde beoordelingsmethode (vrije oordeel) werd geen inhoudelijke instructie gegeven, terwijl de meest uitgebreide beoordelingsmethode (uitgebreide criterialijst) verregaand was gedetailleerd. De andere twee beoordelingsmethoden (korte antwoordsleutel en de ingedikte criterialijst) waren in lichte mate gestructureerd.

In het algemeen vinden medici het essentieel om sommige aspecten in een antwoord zwaarder mee te kunnen laten tellen dan andere, aangezien bepaalde handelingen in de beroepspraktijk meer of minder adequaat zijn. Het aanbrengen van wegingsfactoren lijkt in elk geval de acceptatie en de face-validity van de beoordelingsmethode te vergroten. Om de invloed van weging op validiteit te kunnen bestuderen werd bij de gestructureerde beoordelingsmethoden wegingsfactoren aangebracht. Hierbij werd alleen gebruik gemaakt van positieve weging. In eerste instantie was het de bedoeling dat in het onderzoek verschillende wegingsmethoden met elkaar zouden worden vergeleken. De wegingsifactoren zouden dan op inhoudelijke gronden worden bepaald. Tijdens het onderzoek bleken de huisartsen die de beoordelingsmethoden ontwikkelden niet in staat te zijn verschillende wegingsfactoren op inhoudelijke gronden aan te brengen. De methode van positieve weging was de enige wegingsmethode die volgens hen geschikt was. Zodoende werd besloten in het onderzoek alleen de methode van positieve weging te vergelijken met de wegingsmethode waarbij geen gedifferentieerde weging wordt toegepast.

De vragen werden ter beantwoording voorgelegd aan studenten uit verschillende jaargroepen, zodat de validiteit van zowel de casus als de beoordelingsmethoden kon worden onderzocht.

Om de relatieve bijdrage van de beoordelingsmethoden, de beoordelaars, de casus en de studenten op de totale- en de interbeoordelaarsbetrouwbaarheid te kunnen onderzoeken, werd een G-studie uitgevoerd. Op basis van de geschatte variantiecomponenten van de Gstudie werd een aantal verschillende $D$-studies uitgevoerd, waarin bij verschillende designs de invloed van het aantal casus en het aantal beoordelaars op de totale betrouwbaarheid werd bestudeerd. Daarnaast werd in een D-studie de interbeoordelaarsbetrouwbaarheid geschat.

De relatie tussen de medische expertise van de beoordelaars en de mate van structurering van het beoordelingsproces op de betrouwbaarheid werd bestudeerd door in het onderzoek gebruik te maken van drie groepen beoordelaars, die varieerden in medische expertise, te weten: huisartsen, vierdejaars studenten geneeskunde en vierdejaars studenten economie. Het hiervoor beschreven onderzoeksdesign werd bij alle drie de groepen gehanteerd, 
zodat de resultaten met elkaar konden worden vergeleken.

De waardering van de beoordelaars voor de verschillende beoordelingsmethoden werd onderzocht door middel van een vragenlijst. In deze vragenlijst waren vragen opgenomen waarin rechtstreeks naar de beleving van de beoordelaars werd gevraagd. Daarnaast werd een aantal beoordelaars aan een telefonisch interview onderworpen.

Het onderzoek werd in twee fasen uitgevoerd. Allereerst werd een pilot-onderzoek verricht waarin de beoordelingsmethoden werden ontwikkeld en getest. Tevens werden de wegingsfactoren bepaald. Het pilot-onderzoek bood eveneens de mogelijkheid om het onderzoeksdesign te testen op praktische haalbaarheid. Na het pilot-onderzoek werd het hoofdonderzoek uitgevoerd, waarin bovenstaande vraagstellingen werden onderzocht.

\subsection{Verwachtingen}

Op basis van de hiervoor beschreven operationalisatie van de vraagstellingen is het mogelijk specifiek aan het onderzoek gerelateerde verwachtingen en hypothesen te formuleren. In deze paragraaf wordt nader ingegaan op de vraagstellingen. De daaruit voortvloeiende hypothesen worden in de volgende paragraaf beschreven.

\subsubsection{Validiteit}

Aangezien kon worden verwacht dat een student die meer medisch onderwijs had gevolgd beter in staat zou moeten zijn om medische problemen op te lossen, werd verondersteld dat de behaalde score op de casustoets zou toenemen met het aantal jaren gevolgd medisch onderwijs.

Onderzoek heeft aangetoond dat deskundige beoordelaars niet ondeskundig beoordelen, maar dat zij dat inconsistent doen. Een inperking van de vrijheid tijdens het beoordelen leidde tot meer accurate beoordelingen (Cough, 1962; Goldberg, 1968; Wiggins, 1973; Nisbett \& Ross, 1980). Op basis van deze gegevens werd verwacht dat met behulp van de gestructureerde beoordelingsmethoden meer accurate en zodoende meer valide uitspraken zouden worden verkregen. Ook met betrekking tot het discriminerend vermogen werd verondersteld dat deze groter zou zijn bij de gestructureerde beoordelingsmethoden dan bij het vrije oordeel, als gevolg van de meer accurate beoordelingen. Met welke gestructureerde beoordelingsmethode( $n$ ) de meest valide beoordelingen zouden worden gegeven, werd verondersteld voor een belangrijk deel te worden bepaald door de interactie tussen de medische expertise van de beoordelaars en de mate van structurering van het beoordelingsproces (zie 3.6.2).

\subsubsection{Generaliseerbaarheidsanalyses}

Het structureren van het beoordelingsproces heeft naast voordelen ook een aantal nadelen. Zo wordt een te sterke beteugeling van het beoordelingsproces door de beoordelaars niet erg gewaardeerd. Daarnaast blijkt, evenals bij het ontbreken van een beoordelingsvoorschrift, een te ver doorgevoerde structurering de kans op beoordelaarseffecten te vergroten (Cough, 1962; Goldberg, 1968; Nisbett \& Ross, 1980). 
Op grond van deze bevindingen werd het niet waarschijnlijk geacht, dat met het vrije oordeel een hoge interbeoordelaarsbetrouwbaarheid zou worden verkregen. Eenzelfde beeld kon worden verwacht met betrekking tot de uitgebreide criterialijst, aangezien een te ver doorgevoerde structurering het optreden van beoordelaarseffecten lijkt te induceren (Cough, 1962; Goldberg, 1968; Nisbett \& Ross, 1980). Desondanks leek het waarschijnlijk dat bij de uitgebreide criterialijst een hogere interbeoordelaarsbetrouwbaarheid zou worden gevonden dan bij het vrije oordeel, aangezien bij eerstgenoemde de beoordelingstaak door de gestructureerdheid minder complex zou zijn. Verwacht werd dat met de korte antwoordsleutel en de ingedikte criterialijst de grootste overeenstemming tussen de beoordelaars zou worden gevonden. Een uitzondering op deze regel zou wellicht worden gevormd door de groep leken die als beoordelaars fungeerden. Aangezien verondersteld leek te mogen worden dat deze groep nauwelijks over medische kennis en expertise zou beschikken, werd verwacht dat bij deze groep beoordelaars de uitgebreide criterialijst tot de grootste overeenstemming zou leiden. Het leek niet aannemelijk dat bij deze groep beoordelaars een gedetailleerd beoordelingsvoorschrift als "te" gedetailleerd zou worden ervaren. Integendeel, de verwachting was dat de uitgebreide criterialijst het meest tegemoet zou komen aan de behoefte van de beoordelaars. Verwacht werd dan ook dat bij de groep leken de interbeoordelaarsbetrouwbaarheid het hoogst zou zijn bij de uitgebreide criterialijst.

Hoewel de mate van overeenstemming tussen beoordelaars invloed heeft op de totale betrouwbaarheid van een meting, kan niet per definitie worden gesteld dat dit de belangrijkste factor is die de totale betrouwbaarheid bepaalt. Andere factoren zoals de homogeniteit en het discriminerend vermogen van de toets spelen hierbij een rol. Zo ook het aantal en de aard van andere toevalsfactoren.

Dit betekent dat de beoordelingsmethode waarmee de hoogste interbeoordelaarsbetrouwbaarheid wordt verkregen niet per definitie tot de hoogste totale betrouwbaarheid leidt. In hoeverre een dergelijke trend wordt gevonden, hangt voornamelijk af van de relatieve bijdrage van beoordelaarseffecten in verhouding tot de andere factoren die van invloed zijn op de betrouwbaarheid. Verwacht werd dat bij de gestructureerde beoordelingsmethoden persoonsvariantie (=ware variantie) toe zou nemen en dat de errorvariantie zou worden verkleind. Tevens werd verwacht dat de relatieve bijdrage van beoordelaarseffecten op de totale betrouwbaarheid bij de gestructureerde methoden geringer zou zijn dan bij het vrije oordeel. Aangezien werd verondersteld dat bij de uitgebreide criterialijst de invloed van beoordelaarseffecten zou toenemen, werd gerekend op een daling van de totale betrouwbaarheid ten opzichte van de korte antwoordsleutel en de ingedikte criterialijst. Desondanks leek het aannemelijk dat de totale betrouwbaarheid bij de uitgebreide criterialijst hoger zou zijn dan bij het vrije oordeel, aangezien bij laatstgenoemde op een kleinere persoonsvariantie werd gerekend.

Bij de groep leken werd wederom een andere tendens verwacht. Net als bij de interbeoordelaarsbetrouwbaarheid werd bij de totale betrouwbaarheid verwacht dat deze zou toenemen naarmate de beoordelingsmethode meer was gestructureerd. Verondersteld werd dat bij deze groep beoordelaars de error-variantie zou afnemen bij de meer gestructureerde beoordelingsmethoden terwijl de "ware variantie" zou toenemen, resulterend in een hogere totale betrouwbaarheid. 


\subsubsection{Weging}

Zoals reeds in paragraaf 1.3 is beschreven, werden bij PMP's hoge positieve correlaties gevonden tussen het aantal gekozen geïndiceerde en het aantal gekozen niet-geïndiceerde opties. Deze bevindingen leidden tot het voorstel om aparte scores te berekenen voor het aantal gekozen geindiceerde opties en het aantal gekozen niet-geïndiceerde opties in plaats van een gecombineerde score (Grosse, 1981). Bij een aantal onderzoeken naar de invloed van weging op validiteit en betrouwbaarheid lijkt iets soortgelijks waarneembaar. In deze studies werd namelijk de invloed van de combinatie van positieve en negatieve weging op validiteit en betrouwbaarheid onderzocht. Uitgaande van de hoge correlatie tussen het aantal gekozen geïndiceerde en niet-geïndiceerde opties lijkt te mogen worden verondersteld dat een dergelijke wegingsmethode geen effect sorteert, hetgeen ook door de bevindingen wordt bevestigd. Daamaast blijkt veel onderzoek naar de invloed van weging te zijn uitgevoerd bij beoordelingsmethoden voor PMP's. Aangezien is gebleken dat bij PMP's cueing optreedt, is het de vraag of het aanbrengen van wegingsfactoren bij beoordelingsmethoden voor open vraagvormen eenzelfde beeld laat zien. Met name het feit dat een persoon zelf moet bedenken wat wel en wat niet gedaan moet worden, zou tot gevolg kunnen hebben dat een duidelijker onderscheid tussen personen met verschillende vaardigheid in medisch probleemoplossen wordt aangebracht.

Bovenstaande gedachten kunnen eveneens in termen van variantie worden uitgedrukt. Indien het aanbrengen van wegingsfactoren een grotere spreiding van de behaalde scores tot gevolg heeft, leidt weging tot een grotere ware-variantie en heeft het tevens een verhoging van de totale betrouwbaarheid tot gevolg. Het zal duidelijk zijn dat de correlatie tussen de gewogen en de ongewogen scores in dit geval relatief laag zal zijn. Als het aanbrengen van de wegingsfactoren daarentegen weinig tot geen invloed heeft op de spreiding en rangordening van personen zal weging eveneens weinig invloed hebben op de grootle van de ware-variantie en de totale betrouwbaarheid. Logischerwijs wordt dan een hoge correlatie verkregen tussen de gewogen en de ongewogen scores.

In het onderhavige onderzoek werd positieve weging toegepast. Op basis van bovenstaande redenering werd verondersteld dat de aangebrachte positieve weging zou leiden tot grotere variatie tussen de behaalde scores van personen met verschillende capaciteiten, hetgeen onder andere tot uitdrukking zou komen in een lage correlatie tussen de gewogen en de ongewogen scores.

Het aanbrengen van wegingsfactoren komt vaak voort uit de behoefte om bepaalde aspecten van een antwoord hoger te kunnen waarderen dan andere aspecten. Verwacht werd dan ook dat positieve weging van onderdelen in de gestructureerde beoordelingsmethoden de acceptabiliteit van deze methoden zou verhogen. Daamaast leek het waarschijnlijk dat door het aanbrengen van positieve weging de validiteit van de beoordelingsmethoden zou toenemen. Een persoon die over enige medische kennis beschikt, zal hoogst waarschijnlijk bij het beantwoorden van de vragen de meest essentiële aspecten van het goede antwoord vermelden. Een persoon die weinig of geen medische kennis bezit kan bij toeval een aspect noemen. Indien geen onderscheid wordt gemaakt tussen essentiële en minder essentiële aspecten, wat betreft het maximaal aantal te geven punten, bestaat de kans dat een persoon die slechts triviale aspecten vermeldt eenzelfde score behaalt als een persoon die de essentie van de vraag goed heeft. Verwacht werd dat het aanbrengen van positieve weging dit effect zou verkleinen, hetgeen de validiteit van de beoordelingsmethoden ten goede zou komen. 


\subsubsection{Waardering van de beoordelingsmethoden}

Naast het aanbrengen van weging spelen ook andere factoren een rol in de waardering van de beoordelingsmethode door de beoordelaars. Onderzoek naar beoordelingsproblemen bij open vraagvormen heeft aangetoond, dat een te weinig of teveel gestructureerde beoordelingsmethode de kans op beoordelaarseffecten vergroot (Hofstee, 1983). Maar ook lijkt er een natuurlijke behoefte te bestaan aan enige mate van structurering van het beoordelingsproces. Verwacht werd dat de gestructureerde beoordelingsmethoden hoger zouden worden gewaardeerd dan het vrije oordeel, ongeacht de expertise van de beoordelaars. Beoordelaars blijken een te sterk beteugeld beoordelingsproces niet prettig te vinden (Cough, 1962; Goldberg, 1968; Wiggins, 1973; Nisbett \& Ross, 1980). Verwacht werd dat dit gevoel eerder zou optreden bij inhoudsdeskundige beoordelaars dan bij leken, aangezien verondersteld werd, dat leken meer inhoudelijke richtlijnen zouden prefereren dan inhoudsdeskundige beoordelaars. Op basis hiervan werd verwacht dat beide groepen beoordelaars met medische expertise de korte antwoordsleutel het hoogst zouden waarderen, daar deze methode meer recht zou doen aan hun gevoel van deskundigheid. Tevens werd verwacht dat de beoordelaars met de minste expertise het meest gestructureerde model als het prettigst zouden ervaren, omdat deze methode het meest tegemoet komt aan hun gebrek aan inhoudelijke kennis.

\subsection{Hypothesen}

Uitgaande van bovenstaande verwachtingen werd een aantal hypothesen ten aanzien van het onderzoek geformuleerd. De specifieke hypothesen die aan het pilot- en het hoofdonderzoek ten grondslag lagen, worden in de respectievelijke hoofdstukken beschreven. Hieronder wordt per categorie de algemene hypothesen beschreven:

\section{Validiteit}

1. Het discriminerend vermogen van de gestructureerde beoordelingsmethoden is hoger vergeleken met het discriminerend vermogen van het vrije oordeel.

\section{Generaliseerbaarheidsanalyses}

2. Bij het vrije oordeel is de overeenstemming tussen beoordelaars geringer dan bij de gestructureerde beoordelingsmethoden, ongeacht de medische expertise van de beoordelaars.

3. De korte antwoordsleutel en de ingedikte criterialijst leiden tot de grootste overeenstemming tussen de beoordelaars indien de beoordelaars inhoudsdeskundig zijn.

4. Bij leken leidt de uitgebreide criterialijst tot de minste verschillen tussen de beoordelaars.

5. Indien de beoordelaars inhoudsdeskundig zijn, wordt de grootste totale betrouwbaarheid verkregen met de korte antwoordsleutel en de ingedikte criterialijst.

6. De uitgebreide criterialijst leidt tot de hoogste totale betrouwbaarheid bij de beoordelaars zonder medische expertise. 


\section{Weging}

7. Positieve weging verhoogt de acceptabiliteit van de gestructureerde beoordelingsmethoden.

8. Positieve weging verhoogt het discriminerend vermogen van de beoordelingsmethoden.

Waardering van de beoordelingsmethoden

9. De leken vinden de uitgebreide criterialijst het prettigst om mee te werken, terwijl de inhoudsdeskundige beoordelaars de korte antwoordsleutel en de ingedikte criterialijst prefereren. 


\section{HET PILOT-ONDERZOEK}

\subsection{Inleiding}

Om de algemene vraagstellingen van het onderzoek te beantwoorden, werd allereerst een pilot-onderzoek uitgevoerd, waarin een aantal aspecten werden onderzocht en voorbereid. In dit hoofdstuk wordt het pilot-onderzoek beschreven. Hierbij wordt aandacht besteed aan de vraagstellingen, het gehanteerde onderzoeksdesign en de gevonden resultaten. Tevens wordt ingegaan op de gevolgen van deze resultaten voor het uiteindelijke onderzoek.

\subsection{Vraagstellingen}

De vraagstellingen die aan het pilot-onderzoek ten grondslag lagen. kunnen over de volgende categorieën worden onderverdeeld: uitvoerbaarheid van het onderzoek, validiteit, weging, generaliseerbaarheidsanalyse en waardering van de beoordelingsmethoden. Bij de beschrijving van de vraagstellingen zal deze onderverdeling worden gehanteerd.

\section{Uitvoerbaarheid van het onderzoek}

Vraagstelling 1.

Is het onderzoeksdesign praktisch uitvoerbaar?

Deze vraagstelling valt in een viertal deelvragen uiteen:

1a. Is het mogelijk voldoende studenten te werven voor het beantwoorden van de vragen behorende bij de casuïstiek? 
1b. Zijn voldoende huisartsen bereid om de antwoorden van de studenten op de open vragen met de verschillende beoordelingsmethoden na te kijken?

1c. Zijn de schriftelijke instructies kwalitatief voldoende?

1d. Is de geplande tijdsbesteding voor de studenten en beoordelaars correct?

Vraagstelling 2 .

Is het mogelijk voor alle vragen behorende bij de casuïstiek vier in mate van structurering verschillende beoordelingsmethoden te ontwikkelen?

\section{Validiteit}

Vraagstelling 3.

Is het gehanteerde onderzoeksmateriaal valide?

Deze vraagstelling bestaat uit twee deelvragen:

3a. Zijn de casus valide?

3b. Zijn de verschillende beoordelingsmethoden valide?

\section{Weging}

Vraagstelling 4.

Is het mogelijk om op basis van inhoudelijke gronden positieve wegingsfactoren aan te brengen bij de gestructureerde beoordelingsmethoden?

\section{Generaliseerbaarheidsanalyses}

Vraagstelling 5.

In hoeverre leveren de empirische gegevens van het pilot-onderzoek een eerste bevestiging van de hypothesen, wat betreft de invloed van de structurering van de beoordelingsmethoden op de reproduceerbaarheid van scores?

\section{Waardering van de beoordelingsmethoden}

Vraagstelling 6.

Wat vinden de beoordelaars van de mate van structurering van de verschillende beoordelingsmethoden? 


\subsection{Methode}

\subsubsection{Materialen}

\subsubsection{Casus}

Aansluitend op recente ontwikkelingen op het gebied van het meten van vaardigheid in medisch probleemoplossen werd in het onderzoek gebruik gemaakt van korte casus. Elke casus werd gevolgd door één of meer gestructureerde open vragen waarop een kort antwoord moest worden gegeven. Om de lengte van het antwoord in te perken werden "restricted response questions" (Ebel \& Frisbie, 1986) toegepast. Hierdoor was het mogelijk meer vragen aan de kandidaten voor te leggen, hetgeen de toetsbetrouwbaarheid vergroot. Ook de nakijktijd per vraag werd hierdoor verkort. Voor het onderzoek werden acht casus geconstrueerd. Dit aantal was om praktische redenen gekozen, aangezien acht casus het maximale aantal was dat studenten binnen de geplande toetstijd van twee uur konden beantwoorden. Uiteraard was dit aantal niet genoeg om een adequate totale toetsbetrouwbaarheid te bereiken (De Graaff, 1989; Page et al., 1990).

De acht casus waren verdeeld over de vier fasen van het S.O.E.P-schema (Weed, 1961):
S: subjectieve informatie
$\mathrm{O}$ : objectieve informatie
E: evaluatie van de verzamelde gegevens
P: diagnostisch of therapeutisch plan

Om onderlinge afhankelijkheid van de casus te voorkomen, had elke casus betrekking op slechts één fase van het schema. Per fase werden dus 2 casus ontwikkeld met bijbehorende vragen. Het aantal vragen per casus was afhankelijk van de dekking van de casus en varieerde van 1 tot 3 vragen.

Medisch inhoudelijk waren de casus gericht op de huisartspraktijk. Deze keuze kwam voort uit de gedachte dat in dit beroepsveld een groot scala van ziektebeelden aanwezig is, die in het basiscurriculum aan de orde komen.

Bij het beantwoorden van de vragen moesten de studenten zich in de situatie verplaatsen dat zij als huisarts een dergelijke patiënt voor zich kregen. Het antwoord moest dus een zo goed mogelijke afspiegeling zijn van hetgeen zij daadwerkelijk in de huisartspraktijk zouden doen.

Aangezien de casus inhoudelijk een afspiegeling waren van klachten die geregeld in de huisartspraktijk aan de orde komen, heeft de constructie in nauwe samenwerking met huisartsen plaatsgevonden. Deze huisartsen makkten deel uit van de onderzoeksprojectgroep. Als vertrekpunt voor de inhoud van de casus werd een aantal praktijksituaties genomen. Om de inhoudsvaliditeit van de casus te verhogen en de casus af te stemmen op de stadia van het SOEP-schema, werd bepaalde (relevante) informatie aan de inhoud toegevoegd en werden andere gegevens in de patiëntbeschrijving weggelaten. Voordat de casus in het onderzoek werden gebruikt, werden ze aan een aantal medici voorgelegd ter becommentariëring, waama de benodigde aanpassingen werden aangebracht.

Voor meer gedetailleerde informatie omtrent de casus wordt verwezen naar bijlage 1 , waar de totale set van instructie, casus en vragen is opgenomen. 


\subsubsection{Beoordelingsmethoden}

Voor elke vraag werden, zoals eerder vermeld, vier beoordelingsmethoden ontwikkeld:

(1) vrije oordeel

(2) korte antwoordsleutel

(3) ingedikte criterialijst

(4) uitgebreide criterialijst

De essentie van de beoordelingsmethode "vrije oordeel" was, dat geen specifieke inhoudelijke instructie aan de beoordelaar werd gegeven. Bij deze beoordelingsmethode was de beoordelaar vrij zijn eigen standaard en scoringsregels te gebruiken. De enige beperking die de beoordelaar werd opgelegd, was dat voor een antwoord maximaal 100 punten mocht worden toegekend.

Bij de beoordelingsmethode "korte antwoordsleutel" werd in enkele trefwoorden aangegeven wat de belangrijkste aspecten waren die in het antwoord aan bod dienden te komen. Bij sommige vragen betrof dit slechts één aspect, bij andere vragen liep dit op tot een tiental aspecten. Bij het beoordelen mocht de beoordelaar maximaal 100 punten per aspect toekennen. Het gemiddelde van de categoriescores vormde het behaalde resultaat voor een vraag. Iets meer structuur aan het beoordelingsproces werd gegeven door de beoordelingsmethode "ingedikte criterialijst". Bij deze beoordelingsmethode werden alle verschillende aspecten, die tezamen het goede antwoord vormden, opgesomd. In tegenstelling tot de "uitgebreide criterialijst" werden bij de "ingedikte criterialijst" geen synoniemen of verdere toelichting opgenomen. Zowel bij de ingedikte- als bij de uitgebreide criterialijst gold dat per aspect maximaal 100 punten mocht worden toegekend. Bij beide beoordelingsmethoden vormde de gemiddelde score van de behaalde punten op de verschillende aspecten de uiteindelijke score voor een vraag.

De gegeven oordelen werden per categorie in een daarvoor ontwikkeld beoordelingsboekje genoteerd. In dit boekje was voor elke student een score-formulier opgenomen, waarop de beoordelaar bij elke vraag en voor elke categorie het aantal punten kon noteren. In de laatste kolom werd de totaalscore per vraag genoteerd. In bijlage 2 is van de vier beoordelingsmethoden en het score-formulier een gedeelte afgebeeld ter illustratie.

De beoordelingsmethoden werden opgesteld met behulp van antwoorden van twee medici en de antwoorden van de studenten geneeskunde die tijdens het pilot-onderzoek de vragen behorende bij de casuistiek hebben beantwoord (zie 4.3.3). De medici waren medewerkers van de Rijksuniversiteit Limburg. Beide artsen zijn verder niet meer bij het onderzoek betrokken geweest. De huisartsen die de casuistiek hadden samengesteld, waren ook verantwoordelijk voor de inhoudelijke samenstelling van de beoordelingsmethoden.

Per vraag werden alle gegeven antwoorden in drie categorieën onderverdeeld: (1) foutief, (2) correct maar niet essentieel en (3) correct en essentieel.

De antwoorden die in de categorie "foutief" terecht waren gekomen, werden niet in de beoordelingsmethoden opgenomen. De antwoorden behorende tot categorie 2 werden aan een tweede keuring onderworpen. Hierbij werd bekeken in hoeverre het antwoord relevant genoeg was om in een beoordelingsmethode te worden opgenomen. Antwoorden waarvan door de medici werd gevonden dat deze niet met punten dienden te worden gehonoreerd, werden uit de lijst verwijderd.

De overgebleven antwoorden uit categorie 2 en de antwoorden uit categorie 3 werden op 
grond van inhoudelijke criteria in subgroepen onderverdeeld. Op basis van deze subgroepen werden de verschillende beoordelingsmethoden samengesteld. Elke subgroep vormde én categorie van de gestructureerde beoordelingsmethode.

Om de vergelijkbaarheid van de verschillende beoordelingsmethoden te optimaliseren, werd zowel bij de korte antwoordsleutel, de ingedikte criterialijst als de uitgebreide criterialijst dezelfde categorie-indeling aangebracht. De verschillen tussen de beoordelingsmethoden waren gelegen in de mate waarin de categorieën waren uitgewerkt. Hoewel de uitgebreide criterialijst verregaand was gedetailleerd, kan deze beoordelingsmethode niet worden gezien als een zuivere checklist. Voorafgaande aan het onderzoek was het wel de bedoeling een dergelijke checklist te ontwikkelen, in de praktijk bleek dit echter niet realiseerbaar. De huisartsen die verantwoordelijk waren voor de constructie van de beoordelingsmethoden bleken niet in staat te zijn de verschillende aspecten uitputtend uit te diepen. Tevens vonden ze een dergelijke detaillering onwenselijk.

\subsubsection{Vragenlijst}

Om de mening van de beoordelaars over de kwaliteit van de beoordelingsmethoden en de casus te bestuderen, werd een vragenlijst ontwikkeld. De vragenlijst bestond uit een aantal stellingvragen en een aantal meerkeuze vragen. Eén van deze vragen had betrekking op de benodigde nakijktijd, zodat de realiseerbaarheid van het onderzoeksdesign kon worden bestudeerd. Bij deze vraag konden de beoordelaars kiezen tussen de categorieën (1) 0-6 uur, (2) 6-12 uur, (3) 12-18 uur en (4) meer dan 18 uur. In totaal waren 10 vragen in de vragenlijst opgenomen. De lijst werd afgesloten met de mogelijkheid om enkele suggesties/opmerkingen te geven over de beoordelingsmethoden, de casuïstiek en/of het totale onderzoek. De gehele vragenlijst is opgenomen in bijlage 3.

\subsubsection{Subjecten}

In het pilot-onderzoek werden twee groepen personen betrokken: (1) personen die de vragen behorende bij de casuïstiek beantwoordden en (2) personen die de antwoorden met behulp van de verschillende beoordelingsmethoden beoordeelden.

De vragen behorende bij de casuïstiek werden schriftelijk beantwoord door 10 eerste-, 15 vierde- en 15 zesdejaars studenten geneeskunde van de Rijksuniversiteit Limburg.

Het belangrijkste doel van het pilot-onderzoek was de constructie van de beoordelingsmethoden, het empirisch bepalen van de wegingsfactoren en het testen van het onderzoeksmateriaal. Om deze reden werd besloten in het pilot-onderzoek alleen met inhoudsdeskundige beoordelaars te werken. De groep beoordelaars bestond uit 8 huisartsen die allen verbonden waren aan de Rijksuniversiteit Limburg. Alle beoordelaars voerden een eigen huisartspraktijk.

Zowel de studenten als de huisartsen kregen een kleine financiële vergoeding voor hun medewerking aan het onderzoek.

De werving van beide groepen personen heeft op verschillende wijzen plaatsgevonden. De studenten die tijdens het onderzoek de vragen moesten beantwoorden, werden geworven via een schriftelijke oproep. De werving van de medici die als beoordelaar aan 
het pilot-onderzoek hebben deelgenomen, geschiedde via een telefonische benadering. Het werken met vrijwilligers kan een zekere mate van bias hebben geïnduceerd. Het is theoretisch mogelijk dat de studenten die mee hebben gedaan allemaal goede en/of gemotiveerde studenten waren. Eveneens bestaat de mogelijkheid dat de artsen die aan het onderzoek hebben deelgenomen geen afspiegeling zijn van de huisartsen in Nederland.

In het pilot-onderzoek werd slechts met een klein aantal studenten gewerkt waardoor het niet reëel was de representativiteit van de steekproef te controleren. Op basis van het kleine aantal proefpersonen kon van tevoren worden verwacht dat deze groep niet de gehele populatie studenten zou vertegenwoordigen.

\subsubsection{Procedure}

De casus werden onder standaard examencondities aan de studenten aangeboden. Een uitzondering moest echter worden gemaakt voor de zesde jaars studenten die in de coschappenfase zaten. Het bleek organisatorisch onmogelijk om de zesdejaars studenten gelijktijdig in één ruimte te krijgen om de vragen te beantwoorden. Als oplossing werd gekozen hen de vragen thuis te laten beantwoorden, met zowel een uitgebreide mondelinge als een schriftelijke instructie, waarbij uitdrukkelijk werd verzocht geen literatuur bij het beantwoorden van de vragen te gebruiken. Met nadruk werd gewezen op het feit dat het behaalde resultaat op geen enkele wijze invloed had op de studievoortgangsbeoordeling van de studenten, terwijl het raadplegen van literatuur het onderzoek kon verstoren.

De keuze voor deze oplossing werd gerechtvaardigd op grond van eerder onderzoek waarin op gelijke wijze redelijk representatieve gegevens werden verkregen (Van der Vleuten et al., 1989).

Om de invloed van zogenaamde volgorde- en contrasteffecten te beperken, kregen de studenten de casus in verschillende volgorde aangeboden. Alle studenten hadden maximaal twee uren de tijd om de vragen behorende bij de casuïstiek te beantwoorden, hetgeen voldoende bleek.

Nadat alle studenten de vragen hadden beantwoord werden de antwoorden overgetypt. Vervolgens werden de beoordelingsmethoden samengesteld volgens de in paragraaf 4.3.1.2 beschreven procedure.

Vervolgens werden de acht huisartsen geworven, die de antwoorden met de vier beoordelingsmethoden moesten beoordelen. De antwoorden van de studenten werden in getypte vorm aan de beoordelaars ter beoordeling voorgelegd om de invloed van handschriftkwaliteit op de beoordeling te voorkomen en de benodigde nakijktijd te bekorten. De getypte antwoorden werden, met weglating van persoonlijke gegevens van de studenten, aan de 8 medici ter beoordeling voorgelegd. Elke beoordelaar beoordeelde onafhankelijk van de andere beoordelaars. Ter voorkoming van contrast- en volgorde-effecten in het beoordelingsproces begon eveneens niet elke beoordelaar met het nakijken van casus 1, maar startte twee beoordelaars met casus 1, twee andere beoordelaars met casus 3 etc. Daarnaast werd per casus de volgorde van de student-antwoorden verwisseld, om volgorde-effecten tegen te gaan. De twee beoordelaars die met dezelfde casus begonnen, worden in het resterende gedeelte van dit hoofdstuk aangeduid als koppel.

Elk koppel beoordelaars beoordeelde de antwoorden van alle studenten op twee casus met eenzelfde beoordelingsmethode, waarna de volgende twee casus met een meer gestructureerde beoordelingsmethode werden nagekeken. Elke beoordelaar starte twee casus na te 
kijken met het vrije oordeel waarna twee casus werden beoordeeld met de korte antwoordsleutel. De resterende vier casus werden achtereenvolgens paarsgewijs beoordeeld met de ingedikte en de uitgebreide criterialijst.

Deze vaste volgorde werd aangebracht om de interferentie van de verschillende beoordelingsmethoden te minimaliseren. Indien een beoordelaar eerst gebruik zou maken van een gestructureerde beoordelingsmethode, zou hij immers bij de methode van het vrije oordeel hierdoor kunnen zijn beïnvloed, waardoor een minder valide vergelijking tussen de verschillende methoden zou worden verkregen. Een omgekeerde beïnvloeding, effecten van een meer globale beoordelingsmethode op een meer gestructureerde methode, werd minder waarschijnlijk geacht.

De opzet van het design was daarmee zodanig gekozen, dat binnen een jaargroep voor elke beoordelingsmethode en twee casus een gekruist design over de factoren van interesse werd verkregen (zie paragraaf 3.4). In tabel 4.1 wordt de verdeling van de beoordelaars over de verschillende casus en beoordelingsmethoden weergegeven.

Tabel 4.1: De verdeling van de beoordelaars (per koppel) over de beoordelingsmethoden en de casus.

Beoordelaar

\begin{tabular}{|c|c|c|c|c|}
\hline & $\begin{array}{c}\text { vrije } \\
\text { oordeel }\end{array}$ & $\begin{array}{c}\text { korte } \\
\text { antwoord } \\
\text { sleutel }\end{array}$ & $\begin{array}{l}\text { ingedikte } \\
\text { criterialijst }\end{array}$ & $\begin{array}{l}\text { uitgebreide } \\
\text { criterialijst }\end{array}$ \\
\hline \multirow[t]{2}{*}{ koppel 1} & casus 1 & casus 3 & casus 5 & casus 7 \\
\hline & casus 2 & casus 4 & casus 6 & casus 8 \\
\hline \multirow[t]{2}{*}{ koppel 2} & casus 3 & casus 5 & casus 7 & casus 1 \\
\hline & casus 4 & casus 6 & casus 8 & casus 2 \\
\hline \multirow[t]{2}{*}{ koppel 3} & casus 5 & casus 7 & casus 1 & casus 3 \\
\hline & casus 6 & casus 8 & casus 2 & casus 4 \\
\hline \multirow[t]{2}{*}{ koppel 4} & casus 7 & casus 1 & casus 3 & casus 5 \\
\hline & casus 8 & casus 2 & casus 4 & casus 6 \\
\hline
\end{tabular}

Nadat de beoordelaars de antwoorden hadden beoordeeld, werden zij geacht de vragenlijst in te vullen. Daarnaast werden de beoordelaars telefonisch benaderd om hun mening te geven over de casuïstiek, de beoordelingsmethoden en het onderzoek.

Om in het hoofdonderzoek de invloed van positieve weging op betrouwbaarheid en validiteit te kunnen onderzoeken, werd aan de beoordelaars van het pilot-onderzoek gevraagd om per categorie van de gestructureerde beoordelingsmethoden met een schoolcijfer aan te geven hoe zwaar elke categorie zou moeten meetellen in het eindoordeel. Als uiteindelijke weging werd voor elke categorie het gemiddelde van de gegeven oordelen genomen. 


\subsubsection{Statistische analyse}

Voor elke student werden casus-scores berekend, omdat dit de enige score is die gelijk was voor alle beoordelingsmethoden. Bij sommige casus was cen aantal vragen opgenomen die statistisch gezien afhankelijk van elkaar waren. Per vraag werden de sub-scores omgerekend tot een som-score, die vervolgens werd omgezet in een percentage-score:

$\%$-score $=$ (behaalde score/maximaal te behalen score) $\times 100 \%$. De gemiddelde percentagescore voor de vragen behorende bij een casus vormde de casus-score. De uiteindelijke score van een student op de casustoets werd gevormd door de gemiddelde score op de acht casus. De procentuele casusscore en de procentuele toetsscore werden beide gebruikt bij de statistische analyse.

\subsubsection{Validiteit}

Om inzicht te verkrijgen in de theoretische validiteit werden de behaalde scores van de studenten uit de drie cohorten met elkaar vergeleken. Hiertoe werden het gemiddelde en de standaarddeviatie van de score op de casustoets voor elk cohort berekend. Daarnaast werden de correlaties tussen de verschillende beoordelingsmethoden bepaald ter bestudering van de validiteit van de beoordelingsmethoden. Hierbij werd een Pearson correlatie berekend op de behaalde scores van de verschillende beoordelingsmethoden. Naast deze geobserveerde correlaties zijn eveneens de ware correlaties geschat, door middel van de correctie voor attenuatie. De correlatie na de correctie voor de onbetrouwbaarheid van het meetinstrument wordt met behulp van de volgende formule geschat:

$$
r_{x+\infty+\infty}=\frac{r_{x c}}{\sqrt{r_{x r_{c c}}}}
$$

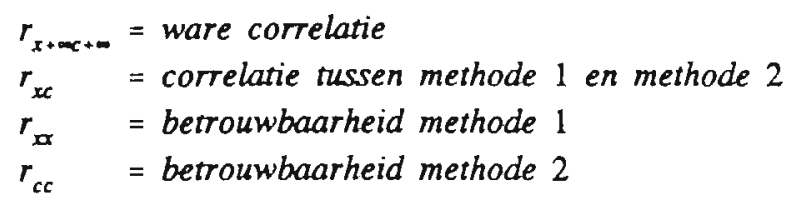

Deze correctie voor onbetrouwbaarheid kan met behulp van zowel de totale- als de interbeoordelaarsbetrouwbaarheid worden uitgevoerd. In het onderhavige onderzoek is voor de correctie gebruik gemaakt van de interbeoordelaarsbetrouwbaarheid. Deze keuze kwam voort uit het gehanteerde onderzoeksdesign. In het onderzoek beoordeelde elk koppel beoordelaars een set van twee casus met één beoordelingsmethode, de volgende twee casus met een meer gestructureerde methode etc. (zie tabel 4.1). Dit betekent dat de antwoorden van alle studenten bij elke casus met alle vier de beoordelingsmethoden werden beoordeeld. Elke beoordelaar beoordeelde per casus de antwoorden van alle studenten slechts met één beoordelingsmethode. De vergelijking van de verschillende beoordelingsmethoden werd dus met name verstoord door eventuele verschillen tussen beoordelaars. De schatting van de ware correlatie werd dan ook uitgevoerd door de 
geobserveerde correlaties te corrigeren voor de verschillen tussen beoordelaars, gebruikmakend van de interbeoordelaarsbetrouwbaarheid.

\subsubsection{Wegingsfactoren}

Voor elke categorie werd het rekenkundig gemiddelde bepaald van de voorgestelde wegingsfactoren. Dit gemiddelde werd als definitieve wegingsfactor in het hoofdonderzoek gebruikt. De overeenstemming tussen de beoordelaars, wat betreft de aangebrachte wegingsfactoren, werd onderzocht met de volgende formule (Cronbach et al., 1972):

$$
I B B=\frac{\hat{\sigma_{i}^{2}}}{\hat{\sigma_{i}^{2}+\bar{\sigma}_{j / n_{j}}^{2}+\bar{\sigma}_{i j / n_{j}}^{2}}}
$$

$$
\begin{array}{ll}
I B B & =\text { interbeoordelaarsbetrouwbaarheid } \\
\overline{\sigma^{2}} & =\text { geschatte variantie } \\
i & =\text { wegingsfactor } \\
j & =\text { beoordelaar } \\
n_{j} & =\text { aantal beoordelaars }
\end{array}
$$

Allereerst werd een ANOVA uitgevoerd, uitgaande van een volledig gekruist $\mathrm{p} x \mathrm{i}$-design. Het hoofdeffect i (wegingsfactor) vormde object van meting, terwijl het facet beoordelaars (j) werd beschouwd als random getrokken uit het domein beoordelaars. De resultaten van de ANOVA werden gebruikt om een schatting te maken van de overeenstemming tussen de verschillende beoordelaars, wat betreft de aangebrachte wegingsfactoren.

\subsubsection{Generaliseerbaarheidsanalyses}

In het pilot-onderzoek werden de bijbehorende G- en D-studies uitgevoerd.

\section{G-studie}

Om een meer valide vergelijking tussen de verschillende beoordelingsmethoden te kunnen maken, werden in de G-studie voor het schatten van de variantiecomponenten alleen de resultaten van de vierde- en zesdejaars studenten gebruikt.

Aangezien de toets niet voor de eerstejaars studenten was bedoeld en deze groep zodoende relatief weinig vragen goed kon beantwoorden, zou de statistische informatie de vergelijking van de beoordelingsmethoden alleen maar verstoren. De eerstejaars studenten waren vooral in het onderzoek betrokken als controlegroep ten behoeve van de validiteitsstudie. 
Een G-studie kan het best worden uitgevoerd met een volledig gekruist design omdat dit meer genuanceerde informatie oplevert dan een genest design. Om ondanks het beperkte aanbod aan beoordelaars een volledig gekruist design te verkrijgen, werd gekozen voor de complexe allocatie van beoordelaars aan casus en beoordelingsmethoden, zoals weergegeven in tabel 4.1 .

Voor het gekozen indelingsschema gold dat binnen elke jaargroep en beoordelingsmethode de antwoorden van alle studenten op twee casus door een koppel beoordelaars werd nagekeken. Voor elk casuspaar werd een ANOVA uitgevoerd en variantiecomponenten geschat ${ }^{1}$. Het studenteffect $(p)$ vormde object van meting, terwijl de facetten casus (i) en beoordelaars (j) als random getrokken uit respectievelijk het domein casus en beoordelaars werd opgevat. Met andere woorden, binnen jaargroep en beoordelingsmethode ontstond voor twee casus een gekruist $\mathrm{p} \mathrm{x} \mathrm{i} \mathrm{x} \mathrm{j} \mathrm{design} \mathrm{(Cronbach} \mathrm{et} \mathrm{al.,} \mathrm{1972).} \mathrm{De} \mathrm{schatting} \mathrm{werd}$ per jaargroep uitgevoerd om de persoonsvariantie niet kunstmatig te vergroten door verschillen tussen jaargroepen. De variantiecomponenten werden gemiddeld over de vier groepen casus en de twee jaargroepen ter verkrijging van één totaal-schatting.

\section{D-studies}

Allereerst werd de interbeoordelaarsbetrouwbaarheid geschat. Voor het schatten van de interbeoordelaarsbetrouwbaarheid werd een ANOVA uitgevoerd die overeenkwam met de wijze waarop de beoordelaars hadden beoordeeld. Zodoende werd een ANOVA uitgevoerd, uitgaande van een j:p-design per beoordelingsmethode voor elk koppel beoordelaars. De schatting vond plaats aan de hand van de volgende formule:

$$
I B B=\frac{\overline{\sigma_{p}^{2}}}{\overline{\sigma_{p}^{2}+\bar{\sigma}_{j: p / n_{i}}^{2}}}
$$

$I B B=$ interbeoordelaarsbetrouwbaarheid

$\sigma^{2}=$ geschatte variantie

$p=$ personen

$j \quad=$ beoordelaar

$n_{j}=$ aantal beoordelaars

Voor de schatting van de totale betrouwbaarheid werd voorts een D-studie uitgevoerd waarin zowel de invloed van het aantal casus als het aantal beoordelaars op de generaliseerbaarheid van de scores werd bestudeerd. De D-studie werd verricht onder de aanname dat alle beoordelaars alle studentantwoorden beoordeelden (een volledig gekruist $\mathrm{p} \mathrm{x}$ i $\mathrm{x}$ jdesign). Bij de schatting van de generaliseerbaarheidscoëfficiënten werd uitgegaan van een

1 De berekeningen werden uitgevoerd met het computerprogramma GENOVA (Crick \& Brennan, 1982). 
norm georiënteerd perspectief, waarin de scores alleen een relatieve betekenis tot elkaar hebben. Dit betekent dat alleen die facetten in de berekening werden meegenomen die betrekking hadden op de rangordening van personen. In tegenstelling tot een domein georiënteerd perspectief, worden in een norm georiënteerd perspectief de factoren die het absolute niveau bepalen buiten beschouwing gelaten. De berekening van de generaliseerbaarheidscoëfficiënten vond plaats met behulp van de volgende formule (Cronbach et al., 1972):

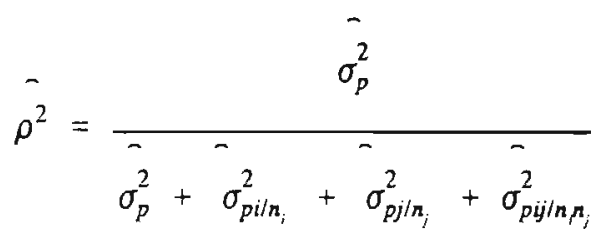

$\rho^{2}=$ generaliseerbaarheidscoëfficiënt

$-$

$\sigma^{2}=$ geschatte variantie

$p=$ personen

$i=$ item

$j=$ beoordelaar

$n_{i}=$ aantalitems

$n_{j}=$ aantal beoordelaars

\subsection{Verwachtingen}

\subsubsection{Uitvoerbaarheid van het onderzoek}

Eén van de doelstellingen van het pilot-onderzoek was de constructie van de beoordelingsmethoden, aan de hand van de student-antwoorden en de antwoorden van een aantal huisartsen. In hoofdstuk 1 werd een aantal onderzoeken beschreven waarbij de overeenstemming tussen artsen bij de constructie van antwoordsleutels voor schriftelijke simulaties gering was (Mazzuca \& Cohen, 1982; Norcini, 1987). Daar staat tegenover dat in de dagelijkse onderwijspraktijk regelmatig beoordelingsvoorschriften worden gemaakt. Verwacht werd dan ook dat het mogelijk moest zijn om voor het onderzoek valide beoordelingsmethoden te ontwikkelen. Daarnaast leek uit onderzoek te mogen worden afgeleid dat de huisartsen die als beoordelaars fungeerden, in staat zouden zijn adequate wegingsfactoren aan te brengen (Norcini, 1987: Webster et al., 1983 ).

Voorafgaande aan het onderzoek werd de benodigde nakijktijd per beoordelaar geschat op acht uur. Hierbij werd uitgegaan van een gemiddelde nakijktijd van anderhalve minuut voor elke casus per student, hetgeen reëel leek gezien de aard van de gestelde vragen. Indien deze raming niet zou overeenstemmen met de werkelijkheid, zou dit consequenties kunnen hebben voor het uiteindelijke onderzoeksdesign van het hoofdonderzoek. 


\subsubsection{Validiteit}

De constructie van de casus heeft in nauwe samenwerking met een aantal huisartsen plaatsgevonden. Bij de inhoudelijke vormgeving van de casus werd uitgegaan van patiënten uit de eigen huisartspraktijk, eventueel met weglating of toevoeging van informatie. Verwacht werd dan ook dat zowel de validiteit als de relevantie van de casus door de studenten en de beoordelaars positief zou worden gewaardeerd. Wat betreft de inhoud van de beoordelingsmethoden werd verondersteld dat de beoordelaars weinig tot geen aanvullingen zouden hebben, aangezien een uitgebreid constructieproces was gehanteerd.

De casus werden verondersteld een afspiegeling te zijn van medische problemen, zoals die zich regelmatig in de huisartspraktijk voordoen. Indien de casus valide zouden zijn, zou mogen worden verwacht dat de student die meer medisch onderwijs heeft genoten, de casus tot een beter eind brengt. Dit betekende dat de behaalde score op deze casustoets zou moeten toenemen naarmate de student meer onderwijs had gevolgd. Verwacht werd dan ook dat de behaalde score het hoogst zou zijn voor de zesdejaars studenten en het laagst voor de eerstejaars studenten.

Verder werd de inhoudsvaliditeit van de beoordelingsmethoden onderzocht aan de hand van een correlationeel onderzoek. Verwacht werd dat een hoge correlatie tussen de gestructureerde beoordelingsmethoden zou worden gevonden. Dit zou dan een indicatie vormen voor het feit dat met de beoordelingsmethoden hetzelfde zou worden gemeten. Wat betreft de correlatie tussen het vrije oordeel en de gestructureerde beoordelingsmethoden werd gerekend op een lagere correlatie, aangezien werd verwacht dat door de grote interpretatieruimte de kans zou bestaan dat verschillende beoordelaars andere aspecten in de beoordeling zouden betrekken.

Aangezien in het pilot-onderzoek alleen met inhoudsdeskundige beoordelaars werd gewerkt, werd verondersteld dat de correlatie tussen het vrije oordeel en de gestructureerde beoordelingsmethoden niet beduidend zou afwijken van de correlaties tussen de gestructureerde beoordelingsmethoden. Wat betreft de hoogte van de correlatie tussen het vrije oordeel en de gestructureerde methoden, werd verwacht dat deze nagenoeg gelijk zou zijn aan de hoogte van de correlatie tussen de beoordelaars bij het vrije oordeel, aangezien de correlatie tussen de beoordelaars bij het vrije oordeel werd opgevat als de minimale te bereiken overeenstemming. Desondanks werd verwacht dat met behulp van de gestructureerde beoordelingsmethoden een beter onderscheid tussen studenten zou worden aangebracht dan met het vrije oordeel, aangezien met de gestructureerde beoordelingsmethoden meer accurate en zodoende meer valide beoordelingen zouden worden gegeven.

\subsubsection{Wegingsfactoren}

Aan de beoordelaars van het pilot-onderzoek werd gevraagd positieve wegingsfactoren aan te brengen bij de categorieën van de gestructureerde beoordelingsmethoden. Onderzoek op het gebied van constructie van antwoordsleutels en het aanbrengen van wegingsfactoren (o.a. Mazzuca \& Cohen, 1982; Norcini, 1987) laat zien dat de constructie geregeld een moeizame aangelegenheid is, waarbij de overeenstemming tussen de betrokken personen niet zelden gering is. Uitgaande van deze ervaringen werd verwacht dat de beoordelaars ieder voor zich in staat zouden zijn een gedifferentieerde weging aan te brengen, maar dat 
de overeenstemming tussen de acht beoordelaars, wat betreft de aangebrachte wegingsfactoren, niet hoog zou zijn.

\subsubsection{Generaliseerbaarheidsanalyses}

Aangezien in het pilot-onderzoek gebruik werd gemaakt van inhoudsdeskundige beoordelaars, werd verwacht dat de overeenstemming tussen de beoordelaars het grootst zou zijn bij de korte antwoordsleutel en de ingedikte criterialijst. Daamaast werd verondersteld dat de minste overeenstemming tussen de beoordelaars zou worden gevonden bij het vrije oordeel (zie paragraaf 3.6.2 voor een verdere onderbouwing van de verwachtingen omtrent de betrouwbaarheid van de verschillende beoordelingsmethoden).

Uitgaande van de veronderstellingen in paragraaf 3.6 .2 werd verwacht dat de totale betrouwbaarheid het hoogst zou zijn bij de korte antwoordsleutel en de ingedikte criterialijst. Ondanks het feit dat werd gewerkt met inhoudsdeskundige beoordelaars, werd verwacht dat de totale betrouwbaarheid het laagst zou zijn bij het vrije oordeel, vanwege de verwachte kleine persoonsvariantie (ware variantie) en de hoge errorvariantie bij deze beoordelingsmethode.

\subsubsection{Waardering van de beoordelingsmethoden}

In het pilot-onderzoek werd alleen gebruik gemaakt van inhoudsdeskundige beoordelaars, zodat overeenkomstig de redenering in paragraaf 3.6.4 werd verwacht dat de beoordelaars de korte antwoordsleutel en de ingedikte criterialijst het prettigst en het meest adequaat zouden vinden.

\subsection{Hypothesen}

Op basis van de verwachtingen werd een aantal hypothesen geformuleerd. De hypothesen die in het pilot-onderzoek werden getoetst, worden in deze paragraaf beschreven. Bij de beschrijving wordt dezelfde indeling gehanteerd als bij de vraagstellingen.

\section{Uitvoerbaarheid van het onderzoek}

1. Het geplande onderzoeksdesign is praktisch uitvoerbaar.

2. Het is mogelijk om op basis van de student-antwoorden en de antwoorden van huisartsen de benodigde beoordelingsmethoden te ontwikkelen.

\section{Validiteit}

3. De beoordelaars vinden de casus valide en relevant voor een casustoets voor het meten van vaardigheid in medisch probleemoplossen.

4. De beoordelaars hebben slechts geringe inhoudelijke aanvullingen op de gestructu- 
5. Er is een duidelijke stijging in de gemiddelde score op de acht casus met een groeiend aantal jaren gevolgd medisch onderwijs.

6. De correlatie tussen de gestructureerde beoordelingsmethoden is hoger dan de correlatie tussen het vrije oordeel en de gestructureerde beoordelingsmethoden.

7. De persoonsvariantie is kleiner bij het vrije oordeel dan bij de gestructureerde beoordelingsmethoden.

\section{Weging}

8. De beoordelaars zijn in staat de verschillende wegingsfactoren aan te brengen bij de gestructureerde beoordelingsmethoden.

9. De overeenstemming tussen de beoordelaars, wat betreft de aangebrachte wegingsfactoren, is laag ( $\leq 0.30$ ).

\section{Generatiseerbaarheidsanalyses}

10. De overeenstemming tussen beoordelaars is het grootst bij de korte antwoordsleutel en de ingedikte criterialijst.

11. De overeenstemming tussen beoordelaars is het kleinst bij het vrije oordeel.

12. De totale toetsbetrouwbaarheid is het hoogst voor de korte antwoordsleutel en de ingedikte criterialijst.

13. De totale toetsbetrouwbaarheid is het laagst voor het vrije oordeel.

\section{Waardering van de beoordelingsmethoden}

14. De beoordelaars vinden de korte antwoordsleutel het prettigst om mee te werken.

15. De beoordelaars vinden de korte antwoordsleutel en de ingedikte criterialijst het meest adequaat om de prestaties van de studenten mee te beoordelen.

\subsection{Resultaten}

\subsubsection{Constructie van het onderzoeksmateriaal}

De constructie van de beoordelingsmethoden vormde een belangrijke doelstelling van het pilot-onderzoek. De constructie verliep op de wijze zoals beschreven in paragraaf 4.3.1.2. Het verdelen van de antwoorden over de drie categorieën leverde de huisartsen, die verantwoordelijk waren voor de constructie van de beoordelingsmethoden, weinig problemen op. Bij de screening van de antwoorden die in categorie 2 (correct maar niet essenticel) terecht waren gekomen, ontstond bij ongeveer $80 \%$ van de antwoorden een discussie tussen huisarsen omtrent de relevantie van het antwoord voor de beoordelingsmethode. Bij het merendeel van deze antwoorden kwamen de huisartsen niet tot een eenduidige beslissing en werd besloten het aspect voorlopig niet in de beoordelingsmethode op te nemen.

Voor meer gedetailleerde informatie omtrent de definitieve beoordelingsmethoden wordt 
verwezen naar bijlage 2 .

\subsubsection{Validiteit}

Nadat de beoordelaars de beoordelingen hadden teruggestuurd werd bij hen een telefonisch interview afgenomen. In dit interview werd gevraagd naar de kwaliteit van de casus en de beoordelingsmethoden. Uit deze interviews bleek slechts een beperkt aantal kleine tekortkomingen in de beoordelingsmethoden aanwezig te zijn. Hierbij moet met name worden gedacht aan het ontbreken van synoniemen en kleine tekstuele opmerkingen. Tevens vonden alle beoordelaars de casus representatief voor een huisartspraktijk.

Als maat voor de theoretische validiteit van het onderzoeksmateriaal werd de relatie tussen de behaalde score en het aantal jaren gevolgd onderwijs genomen. In tabel 4.2 worden per beoordelingsmethode de gemiddelde scores en de standaarddeviatie van het gemiddelde voor elke jaargroep weergegeven. Grafisch worden de gemiddelde scores weergegeven in figuur 4.1 .

De standaarddeviaties varieerden van 8.17 tot 15.05 . Bij de eerstejaars studenten werd relatief de grootste standaarddeviatie gevonden. In de gemiddelde scores van de drie jaargroepen waren enkele trends waameembaar. Zo bleek dat voor elke beoordelingsmethode een positieve relatie bestond tussen het aantal jaren gevolgd onderwijs en de behaalde toetsscore. Ondanks de geringe verschillen tussen de korte antwoordsleutel en de ingedikte criterialijst leek het aanbrengen van meer structuur in de beoordelingsmethode te leiden tot lagere gemiddelde scores. Voorts leek met alle beoordelingsmethoden een evenredig onderscheid tussen de jaargroepen te kunnen worden aangebracht.

Tabel 4.2: Gemiddelde scores en standaarddeviaties per beoordelingsmethode voor elke jaargroep.

Beoordelingsmethode Jaargroep

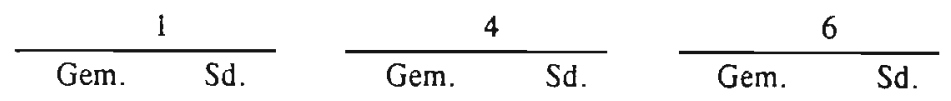

$\begin{array}{lrrrrrr}\text { vrije oordeel } & 19.58 & 10.10 & 45.43 & 13.47 & 54.81 & 8.38 \\ \text { korte antwoord sleutel } & 15.79 & 8.17 & 36.21 & 7.32 & 44.59 & 8.85 \\ \text { ingedikte crit. } & 17.21 & 10.11 & 37.67 & 15.05 & 46.32 & 4.10 \\ \text { uitgebreide crit. } & 12.02 & 9,74 & 30.92 & 14.96 & 38.10 & 8.56\end{array}$




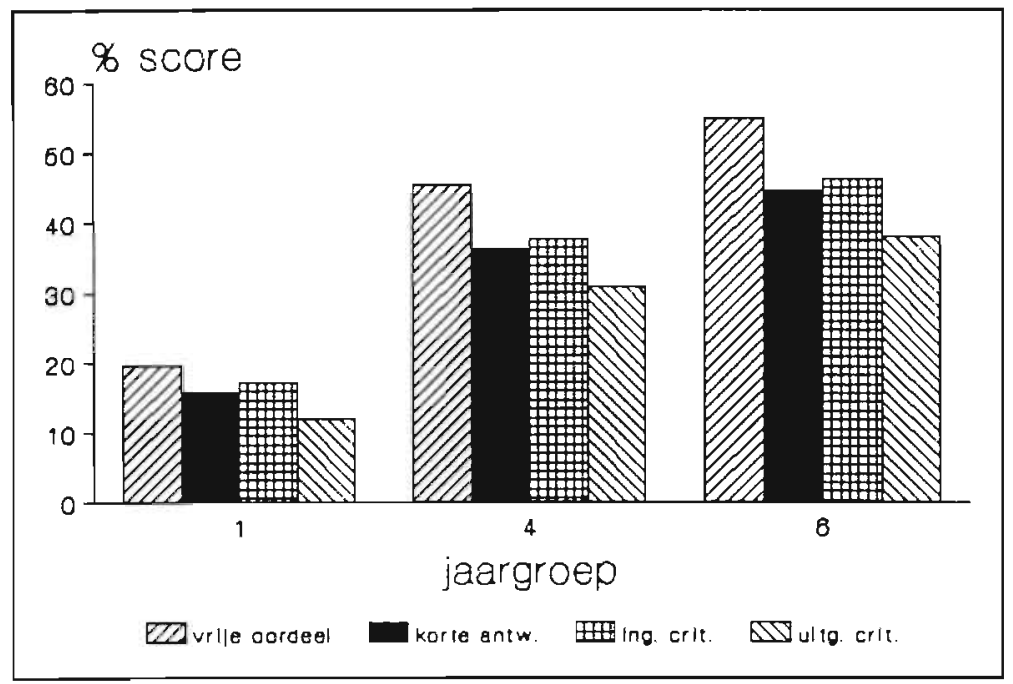

Figuur 4.1: Gemiddelde score voor elke jaargroep per beoordelingsmethode.

Naast het gemiddelde en de standaarddeviatie werd de correlatie tussen de verschillende beoordelingsmethoden onderzocht. Deze correlaties zijn weergegeven in tabel 4.3. De correlaties linksonder in tabel 4.3 zijn de geobserveerde correlaties tussen de beoordelingsmethoden, terwijl de cursief afgedrukte waarden rechtsboven in de tabel de hoogte van de correlatie na de correctie voor attenuatie weergeven. Deze correctie voor de onbetrouwbaarheid is uitgevoerd met de interbeoordelaarsbetrouwbaarheid (zie 4.6.4.2.1).

Tabel 4.3: Geobserveerde en geattenueerde correlaties tussen de verschillende beoordelingsmethoden (respectievelijk in de linker benedenhoek en de rechter bovenhoek) $(n=8)$.

Bewordelingsmethode vrije oordeel korte antw. sleutel ingedikte crit. uitgebreide crit.

vrije oordeel

korte antw. sleutel

ingedikte crit.

uitgebreide crit.
1.00

0.52

0.52

0.52
1.00

1.00

0.82

0.96

1.00

Uit de tabel blijkt dat de correlatie tussen de beoordelingsmethoden varieerde van 0.46 tot 0.61 , zonder correctie voor attenuatie. Hoewel de correlatie tussen de ingedikte en de uitgebreide criterialijst het hoogst was, bleken er nauwelijks verschillen te bestaan in de geobserveerde correlaties tussen enerzijds het vrije oordeel en de gestructureerde beoordelingsmethoden en anderzijds de geobserveerde correlaties tussen de gestructureerde beoordelingsmethoden.

De ware correlaties tussen het vrije oordeel en de gestructureerde beoordelingsmethoden waren gelijk aan 1.0, hetgeen met name werd veroorzaakt door de relatief lage interbeoordelaarsbetrouwbaarheden ( 0.42 bij het vrije oordeel). De ware correlaties tussen de 
korte antwoordsieutel en de ingedikte en uitgebreide criterialijst betrof respectievelijk 0.82 en 0.96 . Dit verschil werd met name veroorzaakt door de relatief lagere interbeoordelaarsbetrouwbaarheid bij de uitgebreide criterialijst. Tussen de ingedikte en de uitgebreide criterialijst werd een ware correlatie gevonden van 1.0. Dit werd veroorzaakt door de combinatie van een lage interbeoordelaarsbetrouwbaarheid bij de uitgebreide criterialijst en de relatief hoge (ten opzicht van de andere geobserveerde correlaties) geobserveerde correlatie tussen beide beoordelingsmethoden.

Zowel de geobserveerde als de ware correlaties toonden geen grote verschillen tussen het vrije oordeel en de gestructureerde beoordelingsmethoden; alle geobserveerde correlaties waren relatief laag en de ware correlaties (vrijwel) altijd perfect.

\subsubsection{Wegingsfactoren}

De huisartsen die in het pilot-onderzoek als beoordelaars fungeerden werd gevraagd om per categorie en sub-categorie van de uitgebreide criterialijst met een schoolcijfer aan te geven hoe zwaar de desbetreffende categorie zou moeten meetellen in het eindoordeel. Zes van de acht beoordelaars zijn aan dit verzoek tegemoetgekomen. Eén van deze beoordelaars had echter geen gedifferentieerde weging aangebracht.

De resultaten van de ANOVA zijn weergegeven in tabel 4.4.

Tabel 4.4: Resultaten van de ANOVA uitgevoerd op de wegingsfactoren.

\begin{tabular}{lcccc}
\hline $\begin{array}{c}\text { Variantie } \\
\text { bron }\end{array}$ & $\begin{array}{c}\text { Degrees of } \\
\text { freedom }\end{array}$ & $\begin{array}{c}\text { Sum of } \\
\text { squares }\end{array}$ & Mean square & $\begin{array}{c}\text { Variantie } \\
\text { component }\end{array}$ \\
\hline wegingsfactor & 45 & 968.50 & 2.89 & 0.22 \\
beoordelaar & 5 & 868.93 & 6.13 & 0.13 \\
w x b & 225 & 1357.00 & 1.59 & 1.59 \\
\hline
\end{tabular}

De bijdrage van de beoordelaars aan de totale variantie is relatief klein vergeleken met de bijdrage van de variantiecomponenten behorende bij het hoofdeffect wegingsfactoren. De component voor het hoofdeffect wegingsfactoren geeft de variatie aan tussen de aangebrachte wegingsfactoren. Uit de (relatief) grote variantiecomponent blijkt dat door de beoordelaars een grote variatie aan wegingsfactoren is aangebracht. Tevens blijkt uit de (relatief) kleine component voor het hoofdeffect beoordelaars, dat de beoordelaars relatief weinig verschilden in de range van de aangebrachte wegingsfactoren. De mate waarin de beoordelaars overeenstemden in de aangebrachte wegingsfactoren bij de 46 categorieën werd geschat met behulp van de intraclass correlatie (zie 4.3.4.2):

$$
I B B=\frac{0.22}{0.22+0.13 / 6+1.59 / 6}=0.43
$$

De intraclass correlatie is gelijk aan 0.43 , hetgeen betekent dat de beoordelaars sterk verschilden in de toekenning van wegingsfactoren aan de verschillende categorieën van de gestructureerde beoordelingsmethoden. 


\subsubsection{Generaliseerbaarheidsanalyses}

\subsubsection{G-studie}

Tabel 4.5 bevat de geschatte variantiecomponenten en de bijbehorende standard errors uit de G-studie, uitgesplitst per beoordelingsmethode.

Tabel 4.5: Geschatte variantiecomponenten en standard errors per beoordelingsmethode voor de verschillende hoofd- en interactie-effecten.

\begin{tabular}{|c|c|c|c|c|c|c|c|c|}
\hline \multirow[t]{3}{*}{$\begin{array}{l}\text { Var. } \\
\text { bron }\end{array}$} & \multicolumn{8}{|c|}{ Beoordelingsmethode } \\
\hline & \multicolumn{2}{|c|}{ vrije oordeel } & \multicolumn{2}{|c|}{$\begin{array}{c}\text { korte antwoord } \\
\text { sleutel }\end{array}$} & \multicolumn{2}{|c|}{$\begin{array}{l}\text { ingedikte } \\
\text { criterialijst }\end{array}$} & \multicolumn{2}{|c|}{$\begin{array}{l}\text { uitgebreide } \\
\text { criterialijst }\end{array}$} \\
\hline & $\begin{array}{l}\text { Var. } \\
\text { comp. }\end{array}$ & $\begin{array}{l}\text { St. } \\
\text { error }\end{array}$ & $\begin{array}{l}\text { Var. } \\
\text { comp. }\end{array}$ & $\begin{array}{l}\text { St. } \\
\text { error }\end{array}$ & $\begin{array}{l}\text { Var. } \\
\text { comp. }\end{array}$ & $\begin{array}{l}\text { St. } \\
\text { error }\end{array}$ & $\begin{array}{l}\text { Var. } \\
\text { comp. }\end{array}$ & $\begin{array}{l}\text { St. } \\
\text { error }\end{array}$ \\
\hline $\mathrm{p}$ & 59.17 & 38.62 & 59.27 & 36.88 & 61.41 & 30.77 & 55.67 & 21.32 \\
\hline $\mathrm{i}$ & 60.32 & 54.94 & 65.74 & 37.01 & 78.68 & 47.38 & 79.92 & 47.70 \\
\hline j & 28.37 & 34.82 & 52.95 & 45.30 & 31.36 & 29.39 & 16.66 & 17.16 \\
\hline $\mathrm{pi}$ & 179.83 & 29.64 & 177.24 & 11.02 & 184.44 & 16.22 & 130.86 & 5.35 \\
\hline $\mathrm{pj}$ & 97.68 & 39.86 & 26.53 & 6.20 & 52.27 & 13.77 & 9.37 & 14.78 \\
\hline ij & 79.54 & 26.25 & 8.75 & 24.85 & 23.56 & 27.81 & 28.18 & 18.24 \\
\hline pij, error & 150.23 & 14.84 & 131.24 & 12.96 & 168.50 & 16.64 & 95.09 & 9.39 \\
\hline
\end{tabular}

$\mathrm{Bij}$ de variantiecomponenten werden grote standard errors gevonden, hetgeen het gevolg is van de kleinschaligheid van het onderzoek. Het is dan ook noodzakelijk om bij de interpretatie van de resultaten van de G- en D-studie hiermee rekening te houden en bij het trekken van conclusies grote voorzichtigheid te betrachten.

De variatie tussen de scores van de studenten komt tot uitdrukking in het hoofdeffect personen ( $p$ ), hetgeen dus aangeeft in welke mate ware verschillen tussen personen bestaan. De gevonden p-componenten waren vrijwel gelijk voor de verschillende beoordelingsmethoden, hoewel de component wat groter was voor de ingedikte criterialijst. Het hoofdeffect i geeft de variatie tussen de verschillende casus weer. Uit tabel 4.5 blijkt dat de verschillen tussen de casus toenamen naarmate een meer gestructureerde beoordelingsmethode werd gehanteerd. Het hoofdeffect beoordelaars (j) geeft aan in welke mate de beoordelaars systematisch strenger of milder beoordeelden. Opvallend is dat dit effect het grootst was bij de korte antwoordsleutel. Dit effect was het kleinst bij de uitgebreide criterialijst.

Als beoordelaars gemiddeld genomen weinig van elkaar verschillen, dan kunnen zij toch inconsistent over personen en casus beoordelen. Het verschil tussen beoordelaars in rangordening van personen is terug te vinden in het interactie-effect pj. Uit tabel 4.5 blijkt dat deze component beduidend groter was bij het vrije oordeel. Bij de uitgebreide criterialijst trad dit effect het minst op. Ook het interactie-effect $\mathrm{ij}$, dat de verschillen 
tussen beoordelaars op de casus weergeeft, was het grootst bij het vrije oordeel.

Het interactie-effect pi geeft aan in welke mate personen anders worden gerangordend op de verschillende casus. Deze variantiecomponent was bij alle beoordelingsmethoden groot. Dit is gebruikelijk bij instrumenten voor medisch probleemoplossen en wijst op hetgeen in de literatuur wordt aangeduid met het probleem van de inhoudsspecificiteit (Elstein et al., 1978).

Zowel de pi als de pij (error term) effecten waren groot voor de minst gestructureerde beoordelingsmethode. Opvallend was de relatief hoge waarde voor deze effecten bij de ingedikte criterialijst. Beide effecten waren echter beduidend kleiner voor de uitgebreide criterialijst.

Kortom, er zijn kleine verschillen tussen de beoordelingsmethoden waameembaar, die echter in het licht van de grote standard errors weinig betekenis hebben. Wel lijkt een systematische trend waarneembaar dat naarmate de structuur van de beoordelingsmethode sterker wordt, de inconsistentie van beoordelaars over items en personen kleiner wordt. In hoeverre de gevonden trends ook terug werden gevonden in de verschillende D-studies wordt in de volgende paragrafen beschreven.

\subsubsection{D-studies}

\subsection{Interbeoordelaarsbetrouwbaarheid}

De overeenstemming tussen de beoordelaars per beoordelingsmethode staat vermeld in tabel 4.6.

Tabel 4.6: Interbeoordelaarsbetrouwbaarheid per beoordelingsmethode.

\begin{tabular}{lc} 
Beoordelingsmethode & $\begin{array}{c}\text { interbeoordelaars- } \\
\text { betrouwbaarheid }\end{array}$ \\
vrije oordeel & 0.42 \\
korte antwoord sleutel & 0.57 \\
ingedikte criterialijst & 0.55 \\
uitgebreide criterialijst & 0.56 \\
\hline
\end{tabular}

De interbeoordelaarsbetrouwbaarheid was het laagst voor het vrije oordeel. Voor de drie gestructureerde beoordelingsmethoden werd nagenoeg dezelfde waarde voor de interbeoordelaarsbetrouwbaarheid gevonden. Hoewel de gevonden waarde voor alle beoordelingsmethoden relatief laag was, leek het bieden van enige mate van structuur positief te werken op de overeenstemming tussen beoordelaars.

\subsection{Totale toetsbetrouwbaarheid}

In deze D-studie werd de totale betrouwbaarheid geschat als functie van het aantal casus 
en het aantal beoordelaars, vanuit een norm georiënteerd perspectief. Hierbij werd uitgegaan van een volledig gekruist $\mathrm{p}$ x i x j-design, waarin alle beoordelaars alle vragen van alle studenten nakeken. De betrouwbaarheidsindices werden geschat aan de hand van de formule die is beschreven in paragraaf 4.2.4. De generaliseerbaarheidscoëfficiënten zijn weergegeven in tabel 4.7 .

Tabel 4.7: Generaliseerbaarheidscoëfficiënten als een functie van het aantal casus en beoordelaars bij een volledig gekruist design ( $p \times$ i $x$ j), vanuit een norm georiënteerd perspectief.

\begin{tabular}{|c|c|c|c|c|c|c|c|c|}
\hline \multirow{3}{*}{$\begin{array}{c}\text { aantal" } \\
\text { casus }\end{array}$} & \multicolumn{8}{|c|}{ Beoordelingsmethode } \\
\hline & \multicolumn{2}{|c|}{ vrije oordeel } & \multicolumn{2}{|c|}{$\begin{array}{c}\text { korte } \\
\text { antwoord } \\
\text { sleutel }\end{array}$} & \multicolumn{2}{|c|}{$\begin{array}{l}\text { ingedikte } \\
\text { criterialijst }\end{array}$} & \multicolumn{2}{|c|}{$\begin{array}{l}\text { uitgebreide } \\
\text { criterialijst }\end{array}$} \\
\hline & $\begin{array}{l}\text { én } \\
\text { beoo }\end{array}$ & $\begin{array}{l}\text { twee } \\
\text { elaars }\end{array}$ & $\begin{array}{l}\text { een } \\
\text { beoo }\end{array}$ & $\begin{array}{l}\text { twee } \\
\text { elaars }\end{array}$ & $\begin{array}{l}\text { eén } \\
\text { beoo }\end{array}$ & $\begin{array}{l}\text { twee } \\
\text { laars }\end{array}$ & $\begin{array}{l}\text { eén } \\
\text { beoo }\end{array}$ & $\begin{array}{l}\text { twee } \\
\text { elaars }\end{array}$ \\
\hline 4 & 0.36 & 0.44 & 0.41 & 0.48 & 0.38 & 0.46 & 0.49 & 0.55 \\
\hline 8 & 0.53 & 0.61 & 0.59 & 0.65 & 0.55 & 0.63 & 0.65 & 0.71 \\
\hline 12 & 0.62 & 0.70 & 0.68 & 0.74 & 0.65 & 0.72 & 0.74 & 0.79 \\
\hline 16 & 0.69 & 0.76 & 0.74 & 0.79 & 0.71 & 0.77 & 0.79 & 0.83 \\
\hline 20 & 0.73 & 0.80 & 0.78 & 0.82 & 0.76 & 0.81 & 0.83 & 0.86 \\
\hline 24 & 0.77 & 0.82 & 0.81 & 0.85 & 0.79 & 0.84 & 0.85 & 0.88 \\
\hline 32 & 0.82 & 0.86 & 0.85 & 0.88 & 0.83 & 0.87 & 0.88 & 0.91 \\
\hline 40 & 0.85 & 0.89 & 0.88 & 0.90 & 0.86 & 0.89 & 0.90 & 0.92 \\
\hline
\end{tabular}

* 4 casus is ongeveer 1 uur toetstijd

De generaliseerbaarheidscoëfficiënten behorende bij het vrije oordeel waren onder dezelfde omstandigheden (hetzelfde aantal casus en beoordelaars) altijd het laagst. De hoogste coëfficiënten werden verkregen met de uitgebreide criterialijst. Desondanks lijkt de generaliseerbaarheid van de scores niet lineair toe te nemen met de mate van structurering. Zo werd met de korte antwoordsleutel betere resultaten verkregen dan met de ingedikte criterialijst.

Het toevoegen van een tweede beoordelaar leidde niet tot systematische verschillen tussen beoordelingsmethoden, ondanks de gevonden verschillen in de interbeoordelaarsbetrouwbaarheid. Blijkbaar overschaduwden de overige foutenbronnen de interbeoordelaarsverschillen dusdanig dat er geen differentiële effecten waren over beoordelingsmethoden, hetgeen reeds zichtbaar was in de verhouding tussen de variantiecomponenten. Voor de totale betrouwbaarheid gold, dat voor alle beoordelingsmethoden het effectiever was het aantal casus te vergroten dan een tweede beoordelaar toe te voegen, hetgeen op basis van de relatief veel grotere pi en pij variantiecomponenten al verwacht kon worden.

Tenslotte blijkt uit tabel 4.7 dat bij alle beoordelingsmethoden een groot aantal casus nodig was om een acceptabele betrouwbaarheid te verkrijgen. 


\subsubsection{Waardering van de beoordelingsmethoden}

Uit de antwoorden op de vragenlijst kwam naar voren dat de beoordelaars de korte antwoordsleutels het prettigst vonden om mee te werken. Allen waren echter van mening dat met zowel de korte antwoordsleutel als de ingedikte criterialijst de antwoorden van de studenten op een adequate wijze konden worden beoordeeld. Het minst tevreden waren de beoordelaars met de uitgebreide criterialijst omdat ze deze te tijdrovend vonden.

In totaal bleken de beoordelaars tussen de 6 en 12 uur nodig te hebben om alle antwoorden te beoordelen. Aangezien elke beoordelaar slechts twee casus met behulp van éen type beoordelingsmethode had nagekeken was het in dit onderzoek onmogelijk te achterhalen of de benodigde tijd varieerde voor de verschillende beoordelingsmethoden.

\subsection{Conclusies}

Voorafgaande aan het pilot-onderzoek werden vijftien hypothesen geformuleerd, die in het onderzoek moesten worden getoetst (zie 4.5). Deze hypothesen werden onderverdeeld in een aantal categorieën. In deze paragraaf wordt per hypothese ingegaan op de consequenties van de resultaten voor de hypothesen.

\subsubsection{Uitvoerbaarheid van het onderzoek}

Hypothese 1: Het geplande onderzoeksdesign is praktisch uitvoerbaar.

Het werven van de studenten voor het beantwoorden van de vragen behorende bij de casuistiek leverde tijdens het pilot-onderzoek geen enkel probleem op. Binnen enkele dagen hadden zich meer studenten aangemeld dan voor het pilot-onderzoek noodzakelijk was. De werving van de huisartsen voor het pilot-onderzoek leverde eveneens geen moeilijkheden op. Na een week hadden zich acht artsen bereid verklaard als beoordelaar op te treden. Op basis van deze resultaten leek het werven van een voldoende aantal studenten en beoordelaars voor het hoofdonderzoek geen problemen te hoeven opleveren. Naast de werving van de proefpersonen vormde ook de tijdsbesteding van de proefpersonen een belangrijk aspect met betrekking tot de uitvoerbaarheid van het design. In het pilot-onderzoek waren de geplande twee uren voor het beantwoorden van de vragen toereikend. Voorts bleek uit de gegevens dat de beoordelaars de verwachte zes tot twaalf uren nodig hadden om alle antwoorden van de 40 studenten na te kijken.

De gegevens kwamen overeen met de verwachtingen en vormden een bevestiging van de praktische realiseerbaarheid van het onderzoeksdesign.

Hypothese 2: Het is mogelijk op basis van de student-antwoorden en de antwoorden van huisartsen de benodigde beoordelingsmethoden te ontwikkelen.

In het pilot-onderzoek bleek het mogelijk om de vier in mate van structuur verschillende beoordelingsmethoden samen te stellen. De gegeven antwoorden door de studenten en de antwoorden van een aantal huisartsen vormden voor de samenstellers een goede basis. Wel ontstond bij $80 \%$ van de aspecten die in categorie 2 (correct maar niet essentieel) 
terecht waren gekomen discussies omtrent de relevantie van de desbetreffende aspecten. Deze resultaten zijn in overeenstemming met de gegevens die in de literatuur worden vermeld, waarbij slechts een beperkte overeenstemming tussen verschillende samenstellers van antwoordsleutels wordt gerapporteerd (Marshall, 1977; Barrows et al., 1978; Mazzuca, 1982). Deze gegevens vormden een bevestiging van bovenstaande hypothese.

\subsubsection{Validiteit}

Hypothese 3: De beoordelaars vinden de casus valide en relevant voor een casustoets voor het meten van vaardigheid in medisch probleemoplossen.

Uit de antwoorden op de vragenlijst en de reacties tijdens de telefoongesprekken na afloop van het onderzoek bleek dat alle beoordelaars de casuïstiek representatief en adequaat vonden. Ook de studenten die de vragen behorende bij de casuïstiek hadden beantwoord waren enthousiast over de inhoud, de relevantie en vormgeving van de casus. Deze resultaten vormden een volledige bevestiging van de hypothese en kan eveneens worden opgevat als een bevestiging van de face-validity van de casus.

Hypothese 4: De beoordelaars hebben slechts geringe inhoudelijke aanvullingen op de gestructureerde beoordelingsmethoden.

De huisartsen die de antwoorden van de studenten op de vragen aan de hand van de beoordelingsmethoden hadden beoordeeld, constateerden geen inhoudelijke tekortkomingen in de gestructureerde beoordelingsmethoden. Wel werd door een aantal beoordelaars bruikbare suggesties gegeven die konden worden gebruikt om de beoordelingsmethoden inhoudelijk aan te vullen. Dit betrof met name aanvullende synoniemen en andere kleine tekstuele wijzigingen. Deze gegevens werden opgevat als een verificatie van bovenstaande hypothese.

Hypothese 5: Er is een duidelijke stijging in de gemiddelde score op de acht casus met een groeiend aantal jaren gevolgd medisch onderwijs.

Uit de resultaten bleek dat de gemiddelde score op de casustoets toenam naarmate de studenten meer medisch onderwijs hadden gevolgd. Deze trend werd bij alle vier de beoordelingsmethoden gevonden en vormden een volledige bevestiging van de hypothese. Deze resultaten konden tevens worden opgevat als een indicatie voor de theoretische validiteit van de casus.

Hypothese 6: De correlatie tussen de gestructureerde beoordelingsmethoden is hoger dan de correlatie tussen het vrije oordeel en de gestructureerde beoordelingsmethoden.

De geobserveerde correlaties tussen de gestructureerde beoordelingsmethoden onderling en de correlatie tussen het vrije oordeel en de gestructureerde beoordelingsmethoden 
waren beide relatief laag. Na de correctie van attenuatie waren de correlaties tussen de beoordelingsmethoden daarentegen (bijna) perfect. De verwachte verschillen in de hoogte van de correlaties werden niet gevonden, op basis waarvan de hypothese moest worden verworpen.

Hypothese 7: De persoonsvariantie is kleiner bij het vrije oordeel dan bij de gestructureerde beoordelingsmethoden.

Van tevoren werd verwacht dat de persoonsvariantie bij het vrije oordeel kleiner zou zijn dan bij de gestructureerde beoordelingsmethoden ten gevolge van het feit dat met het vrije oordeel andere aspecten in de beoordeling zouden worden meegenomen (error-variantie). De resultaten van de G-studie verwierpen deze hypothese, aangezien de grootte van de variantiecomponent behorende bij het hoofdeffect personen vrijwel gelijk was bij alle vier de beoordelingsmethoden. De correlaties tussen de beoordelingsmethoden ondersteunden de falsificatie van de hypothese; de correlaties tussen het vrije oordeel en de gestructureerde beoordelingsmethoden waren niet lager vergeleken met de correlaties tussen de gestructureerde beoordelingsmethoden.

\subsubsection{Weging}

Hypothese 8: De beoordelaars zijn in staat de verschillende wegingsfactoren aan te brengen bij de gestructureerde beoordelingsmethoden.

Naast de samenstelling van de beoordelingsmethoden had het pilot-onderzoek tot doel te komen tot op inhoudelijke gronden gekozen positieve wegingsfactoren voor de gestructureerde beoordelingsmethoden. Zes van de acht beoordelaars kenden aan elke categorie wegingsfactoren toe, terwijl twee beoordelaars geen gehoor gaven aan het verzoek. Van deze zes beoordelaars brachten vijf beoordelaars een gedifferentieerde weging aan en vond één beoordelaar elke categorie even belangrijk. Op basis van deze gegevens lijkt te kunnen worden geconcludeerd dat het mogelijk is positieve wegingsfactoren op inhoudelijke gronden aan te brengen.

Hypothese 9: De overeenstemming tussen de beoordelaars, wat betreft de aangebrachte wegingsfactoren, is laag $(\leq 0.30)$.

Zoals werd verwacht werden met betrekking tot de aangebrachte wegingsfactoren verschillen tussen beoordelaars gevonden. De overeenstemming tussen de beoordelaars, wat betreft de aangebrachte wegingsfactoren was groter dan verwacht, maar steeg niet uit boven de 0.43 . Dit resultaat week gedeeltelijk af van de in de hypothese geformuleerde verwachting. 


\subsubsection{Generaliseerbaarheidsanalyses}

\subsubsection{Interbeoordelaarsbetrouwbaarheid}

Ondanks de kleinschaligheid van het pilot-onderzoek werden op de gegevens enkele analyses uitgevoerd om een eerste indruk te krijgen van de te verwachten resultaten van het hoofdonderzoek. Het was van tevoren duidelijk dat het werken met een dusdanig kleine groep proefpersonen ten koste zou gaan van de validiteit van de uitkomsten. Bij het trekken van conclusies moet hiermee rekening worden gehouden.

Allereerst werd de overeenstemming tussen de beoordelaars berekend, wat betreft de gegeven beoordelingen. Met betrekking tot de interbeoordelaarsbetrouwbaarheid waren twee hypothesen geformuleerd, die hieronder gelijktijdig worden bediscussieerd.

Hypothese 10: De overeenstemming tussen de beoordelaars is het grootst bij de korte antwoordsleutel en de ingedikte criterialijst.

Hypothese 11: De overeenstemming tussen de beoordelaars is het kleinst bij het vrije oordeel.

De gevonden coëfficiënten voor de overeenstemming tussen de beoordelaars waren relatief laag (variërend van 0.42 tot 0.57 ). De overeenstemming tussen de beoordelaars nam toe ten gevolge van het aanbrengen van structuur. Met name bij het vrije oordeel verschilden de beoordelaars sterk in de mate van consistentie over casus en personen heen. Deze resultaten kunnen worden opgevat als een aanwijzing dat het structureren van beoordelingsmethoden leidt tot verbetering van de consistentie van de beoordelaars over studenten en casus. Wat betreft de interbeoordelaarsbetrouwbaarheid werden geen verschillen gevonden tussen de drie gestructureerde beoordelingsmethoden. De hypothesen met betrekking tot de interbeoordelaarsbetrouwbaarheid werden door de resultaten gedeeltelijk bevestigd.

\subsubsection{Totale toetsbetrouwbaarheid}

Met betrekking tot de totale toetsbetrouwbaarheid werd een tweetal hypothesen geformuleerd, die eveneens gelijktijdig worden bediscussieerd.

Hypothese 12: De totale toetsbetrouwbaarheid is het hoogst voor de korte antwoordsleutel en de ingedikte criterialijst.

Hypothese 13: De totale toetsbetrouwbaarheid is het laagst voor het vrije oordeel.

Uit de resultaten van de D-studie bleek dat bij een norm-georiënteerd perspectief en een volledig gekruist design, de uitgebreide criterialijst tot de hoogste reproduceerbaarheid van scores leidde. Bij het vrije oordeel werd de laagste totale betrouwbaarheid gevonden. Deze gegevens vormden geen bevestiging van de hypothese dat de hoogste totale betrouwbaarheid zou worden gevonden bij de korte antwoordsleutel en de ingedikte criterialijst. De verwachting dat het vrije oordeel tot de laagste totale betrouwbaarheid zou leiden werd daarentegen volledig bevestigd. 


\subsubsection{Waardering van de beoordelingsmethoden}

Hypothese 14: De beoordelaars vinden de korte antwoordsleutel en de ingedikte criterialijst het prettigst om mee te werken.

Alle beoordelaars vonden de korte antwoordsleutel de prettigste beoordelingsmethode. De ingedikte en de uitgebreide criterialijst vonden ze te gedetailleerd, terwijl het vrije oordeel naar hun mening te weinig richtlijnen bood. Met name het feit dat het beoordelen met de uitgebreide criterialijst meer tijd kostte en het feit dat de beoordelaars minder ruimte kregen voor eigen inbreng werden als tekortkomingen ervaren. Deze gegevens vormden een gedeeltelijke bevestiging van de hypothese.

Hypothese 15: De beoordelaars vinden de korte antwoordsleutel en de ingedikte criterialijst het meest adequaat om de prestaties van de studenten te beoordelen.

De beoordelaars waren unaniem van mening dat zowel het vrije oordeel als de uitgebreide criterialijst het minst adequaat waren om studenten te beoordelen. Het vrije oordeel vonden de beoordelaars te weinig richtlijnen geven, terwijl de uitgebreide criterialijst als te gedetailleerd werd ervaren. Hoewel de beoordelaars de korte antwoordsleutel het meest prettig vonden om mee te beoordelen, waren allen van mening dat zowel met de korte antwoordsleutel als de ingedikte criterialijst de meest adequate beoordelingen konden worden gegeven. Deze gegevens stemden overeen met de geformuleerde hypothese.

\subsection{Implicaties van het pilot-onderzoek voor het hoofdonderzoek}

Het pilot-onderzoek werd uitgevoerd om voorafgaande aan het hoofdonderzoek een aantal aspecten te onderzoeken en voor te bereiden. In deze paragraaf worden de vraagstellingen die aan het pilot-onderzoek ten grondslag lagen puntsgewijs beantwoord en de consequenties van de resultaten van het pilot-onderzoek voor het hoofdonderzoek beschreven.

\subsubsection{Uitvoerbaarheid van het onderzoek}

Vraagstelling 1: Is het onderzoeksdesign praktisch uitvoerbaar?

Een eerste aspect van de praktische uitvoerbaarheid betreft de werving van de proefpersonen. In het pilot-onderzoek leverde de werving van de eerste-, vierde- en zesdejaars studenten voor het beantwoorden van de vragen bij de casuïstiek geen problemen op. Binnen enkele dagen na de eerste oproep hadden zich meer studenten aangemeld dan voor het onderzoek nodig waren. Met betrekking tot de werving van het benodigd aantal studenten voor het hoofdonderzoek werden dan ook geen problemen verwacht.

Hoewel de werving van de beoordelaars in het pilot-onderzoek geen problemen opleverde, kon niet met zekerheid worden gesteld dat voor het hoofdonderzoek de benodigde huisartsen beschikbaar zouden zijn. De huisartsen die aan het pilot-onderzoek hadden meegewerkt waren allen werkzaam aan de Rijksuniversiteit Limburg. Het resterende gedeelte huisartsen dat werkzaam was aan deze universiteit was niet groot genoeg om aan het benodigde aantal beoordelaars voor het hoofdonderzoek te komen. Daarnaast kon de 
vraag worden gesteld in hoeverre een selectiebias zou optreden als alleen artsen uit deze instelling in het onderzoek zouden worden betrokken. De huisartsen voor het hoofdonderzoek moesten dus noodgedwongen via een andere methode worden benaderd. Gedacht werd aan een schriftelijke oproep in één of meer huisartsenbladen. Uitgaande van ervaringen van collega-onderzoekers werd verondersteld dat op deze wijze het benodigde aantal huisartsen voor het hoofdonderzoek kon worden verkregen.

Met betrekking tot de werving van de student-beoordelaars voor het hoofdonderzoek kon op grond van het pilot-onderzoek geen relevante uitspraak worden gedaan. In hoeverre dit op problemen zou stuiten, moest worden afgewacht.

Een tweede belangrijk aspect van de praktische uitvoerbaarheid van een onderzoek betreft de tijdsbesteding van de proefpersonen. De resultaten van het pilot-onderzoek bevestigden de veronderstelling dat het beoordelen van de antwoorden van 40 studenten tussen de 6 en 12 uur per beoordelaar zou vergen. Het was de bedoeling in het hoofdonderzoek een dubbel aantal studenten uit te nodigen om de vragen behorende bij de casuïstiek te beantwoorden. De vraag was hoeveel beoordelaars nodig zouden zijn om deze antwoorden te beoordelen. Indien wederom acht beoordelaars zouden worden gevraagd, leverde dit een gemiddelde nakijktijd van 12 tot 24 uur per beoordelaar op. Op voorhand werd aangenomen dat huisartsen niet bereid zouden zijn een dergelijk groot aantal uren aan het onderzoek te besteden. Zodoende werd besloten 16 beoordelaars te benaderen, die elk slechts de helft van de studenten zou beoordelen.

In het pilot-onderzoek beoordeelde elke beoordelaar alle antwoorden op twee casus met behulp van één type beoordelingsmethode, waarna alle antwoorden op twee andere casus met een meer gestructureerde beoordelingsmethode werden beoordeeld. Hierdoor was het onmogelijk te achterhalen of er verschillen bestonden tussen de beoordelingsmethoden wat betreft de benodigde nakijktijd. Aangezien voor het hoofdonderzoek hetzelfde design was gepland, was het gewenst om in het hoofdonderzoek de tijdsregistratie per beoordelingsmethode te laten plaatsvinden.

Concluderend kon worden gesteld, dat de resultaten van het pilot-onderzoek geen belemmeringen te zien gaven ten aanzien van de praktische uitvoerbaarheid van het onderzoeksdesign, op grond waarvan werd besloten helzelfde design voor het hoofdonderzoek te hanteren.

Vraagstelling 2: Het is mogelijk voor alle vragen behorende bij de casuïstiek vier in mate van structurering verschillende beoordelingsmethoden te ontwikkelen.

De huisartsen die verantwoordelijk waren voor de samenstelling van de beoordelingsmethoden waren in staat op basis van student-antwoorden en antwoorden van collegahuisartsen de benodigde beoordelingsmethoden samen te stellen. Hierbij dient te worden opgemerkt dat het niet mogelijk bleek een zuivere checklist op te stellen. De beschikbare antwoorden vormden voor de samenstellers een goede leidraad. Kortom, het was in de praktijk mogelijk voor elke vraag vier in mate van structurering verschillende beoordelingsmethoden samen te stellen. In hoeverre deze beoordelingsmethoden kwalitatief voldoende waren, komt in de volgende vraagstelling aan de orde. 


\subsubsection{Validiteit}

Vraagstelling 3: Is het gehanteerde onderzoeksmateriaal valide?

In de literatuur worden tientallen soorten van validiteit onderscheiden. Met betrekking tot de validiteit van de casuïstiek is met name aandacht besteed aan de face-validity en de theoretische validiteit.

Face-validity verwijst naar de mate waarin representatieve personen van mening zijn dat het gebruikte materiaal aan de gestelde eisen voldoet. In het onderzoek werd deze vorm van validiteit bestudeerd aan de hand van de opmerkingen van de studenten die de vragen hadden beantwoord en de artsen die als beoordelaars hadden gefungeerd. Beide groepen waren unaniem van mening dat de casus interessant en representatief waren. Deze opmerkingen kunnen worden opgevat als een bevestiging van de face-validity van de casus.

Als maat voor de theoretische validiteit van de casuïstiek werd de gemiddelde score van de drie jaargroepen genomen. Indien de gemiddelde score hoger was naarmate de studenten meer medisch waren geschoold, werd dit opgevat als een bevestiging voor de theoretische validiteit. In het onderzoek werd inderdaad en dergelijke trend gevonden, hetgeen een indicatie vormde voor de validiteit van de casus.

Tevens bleek er een verband te bestaan tussen de mate van structurering van de beoordelingsmethode en de gemiddelde toetsscore; hoe meer gestructureerd de beoordelingsmethode des te lager de gemiddelde scores. Deze resultaten waren in overeenstemming met eerder gevonden resultaten (Scherpbier et al., 1988). Een mogelijke verklaring is het feit dat bij de gestructureerde beoordelingsmethoden de goede antwoorden steeds meer worden verankerd, met als gevolg dat de bzoordelaars steeds strenger worden. Het lijkt er op dat door het structureren van de beoordelingsmethoden gangbare beoordelaarseffecten, zoals het leniency- en het halo-effect (De Groot, 1965), worden teruggedrongen. Opvallend was dat de gevonden toename in de gemiddelde score verhoudingsgewijs hetzelfde was voor de verschillende beoordelingsmethoden. Het feit dat elke beoordelingsmethode nagenoeg een even goed onderscheid tussen de verschillende jaargroepen aanbracht, was niet in overeenstemming met de verwachtingen. In hoeverre dit het gevolg was van een artefact of de deskundigheid van de beoordelaars was op basis van de resultaten niet te achterhalen. Dit aspect zou in het hoofdonderzoek nader moeten worden bestudeerd.

De validiteit van de beoordelingsmethoden werd bestudeerd aan de hand van de commentaren van de beoordelaars en de correlaties tussen de verschillende beoordelingsmethoden. De huisartsen die als beoordelaars fungeerden hadden geen fundamentele inhoudelijke tekortkomingen in de beoordelingsmethoden geconstateerd. Door een aantal beoordelaars werd wel enkele aanvullingen voorgesteld. Dit betrof met name nog toe te voegen synoniemen en tekstuele opmerkingen. Deze gegevens werden opgevat als een ondersteuning van de face-validity en de inhoudsvaliditeit van de beoordelingsmethoden.

Het correlationeel onderzoek leverde lage geobserveerde correlaties op tussen alle vier de beoordelingsmethoden, terwijl de correlaties na correctie voor attenuatie (vrijwel) perfect waren. Ook de verwachting dat de correlatie tussen de gestructureerde beoordelingsmethoden onderling hoger zou zijn dan de correlaties tussen het vrije oordeel en de gestructureerde beoordelingsmethoden werd niet bevestigd. Het lijkt er dus op dat met alle beoordelingsmethoden gedeeltelijk hetzelfde en gedeeltelijk iets anders wordt beoordeeld. 
deeld. Deze resultaten vormden slechts een beperkte ondersteuning van de inhoudsvaliditeit van de gestructureerde beoordelingsmethoden.

De vraag is welke factoren aan deze resultaten ten grondslag kunnen liggen. Het feit dat de geobserveerde correlaties relatief laag zijn en de ware correlaties (vrijwel) perfect zijn, geeft aan dat er sprake is van onbetrouwbare metingen. Dit blijkt ook uit de lage interbeoordelaarsbetrouwbaarheid (variërend van 0.42 tot 0.57 ).

Een mogelijke verklaring voor de lage geobserveerde correlaties zou kunnen zijn dat in het pilot-onderzoek bij de gestructureerde beoordelingsmethoden de punten alleen per categorie waren gespecificeerd, maar niet bij de sub-categorieën. Bij elke categorie van de gestructureerde beoordelingsmethoden mocht maximaal 100 punten worden gegeven. De meeste categorieën waren onderverdeeld in sub-categorieën. Bij deze sub-categorieën was echter niet aangegeven hoeveel punten deze afzonderlijk konden opleveren. De kans bestaat dat de beoordelaars tussen de sub-categorieën verschillende wegingen hebben toegepast. Hierdoor neemt de variatie in de gegeven beoordelingen toe, hetgeen de correlatie tussen de beoordelingsmethoden negatief beïnvloedt. Indien de lage correlatie hierdoor werd veroorzaakt, betekende dit dat in het hoofdonderzoek een dergelijk resultaat niet mocht worden gevonden.

Dat de correlaties tussen het vrije oordeel en de gestructureerde beoordelingsmethoden niet beduidend lager waren dan de correlaties tussen de gestructureerde beoordelingsmethoden zou het gevolg kunnen zijn van het feit dat in het pilot-onderzoek alleen inhoudsdeskundige beoordelaars waren betrokken, die ook zonder veel "sturing" de belangrijkste aspecten in de beoordeling meenamen. Maar ook het feit dat bij alle beoordelingsmethoden lage interbeoordelaarsbetrouwbaarheden werden gevonden zou aan dit resultaat ten grondslag kunnen liggen.

In hoeverre bovenstaande veronderstellingen klopten moest in het hoofdonderzoek worden bestudeerd. Daamaast leek het wenselijk om in het hoofdonderzoek de validiteit verder te toetsen aan externe criteria. In hoeverre de aangebrachte wegingsfactoren de validiteit van de gestructureerde beoordelingsmethoden zou doen toenemen, moest eveneens in het hoofdonderzoek worden bestudeerd.

\subsubsection{Weging}

Vraagstelling 4: Is het mogelijk om op basis van inhoudelijke gronden positieve wegingsfactoren aan te brengen bij de gestructureerde beoordelingsmethoden?

In het pilot-onderzoek hadden zes van de acht beoordelaars positieve wegingsfactoren aangebracht. De vraag was hoe per categorie de wegingsfactoren van de acht individuele beoordelaars konden worden omgezet tot een definitieve wegingsfactor. In eerste instantie werd overwogen de definitieve wegingsfactoren samen te stellen door middel van een discussie tussen de verschillende huisartsen die de wegingsfactoren hadden aangebracht. In de praktijk bleek het niet realiseerbaar de betreffende huisartsen op één tijdstip bij elkaar te krijgen, om de definitieve wegingsfactoren vast te stellen. Er moest dus noodgedwongen naar een andere methode worden gezocht om op basis van de aangebrachte wegingsfactoren de definitieve factoren te bepalen. Besloten werd om het rekenkundig gemiddelde van de aangebrachte wegingsfactoren per categorie als uiteindelijke weging voor de categorieën te hanterer. 


\subsubsection{Generaliseerbaarheidsanalyses}

Vraagstelling 5: In hoeverre leveren de empirische gegevens van het pilot-onderzoek een eerste bevestiging van de hypothesen, wat betreft de invloed van de structurering van de beoordelingsmethoden op de reproduceerbaarheid van scores?

Zoals in een pilot-onderzoek gebruikelijk is, werd slechts een kleine steekproef gehanteerd. Mede hierdoor moesten de resultaten met grote voorzichtigheid worden geinterpreteerd. Desondanks was een aantal trends waarneembaar die al dan niet in overeenstemming waren met de van tevoren geformuleerde hypothesen.

In het pilot-onderzoek werden de hypothesen over de overeenstemming tussen beoordelaars slechts gedeeltelijk bevestigd. Het aanbrengen van structuur bleek de inconsistentie van beoordelaars over personen en casus terug te dringen. Wat betreft de hoogte van de interbeoordelaarsbetrouwbaarheid werden geen duidelijke verschillen tussen de gestructureerde beoordelingsmethoden gevonden. In hoeverre dit het gevolg was van het feit dat de punten alleen per hoofdcategorie waren gespecificeerd (zie vraagstelling 3 ) moest in het hoofdonderzoek worden onderzocht.

De hypothesen met betrekking tot de totale betrouwbaarheid werden eveneens gedeeltelijk bevestigd. Zoals verwacht, werd de laagste totale betrouwbaarheid verkregen met het vrije oordeel. De hypothese dat met de korte antwoordsleutel en de ingedikte criterialijst de grootste reproduceerbaarheid van scores zou worden verkregen, werd daarentegen niet bevestigd. Het leek er dus op dat naast beoordelaarseffecten ook andere factoren een zeer grote invloed op de totale betrouwbaarheid hadden. In hoeverre dit resultaat berustte op een artefact of als structureel moest worden opgevat, was mede door de grote standard errors onduidelijk. In het hoofdonderzoek moest dit aspect nader worden bestudeerd.

\subsubsection{Waardering van de beoordelingsmethoden}

Vraagstelling 6: Wat vinden de beoordelaars van de mate van structurering van de verschillende beoordelingsmethoden?

De hypothesen met betrekking tot de satisfactie van de beoordelaars met de beoordelingsmethoden werden gedeeltelijk bevestigd. De beoordelaars vonden de korte antwoordsleutel het prettigst om mee te werken. In tegenstelling tot de hypothese werd de ingedikte criterialijst minder prettig ervaren dan de korte antwoordsleutel. Wat betreft de adequaatheid van de beoordelingsmethoden vormden de gegevens een volledige bevestiging van de hypothese; zowel de korte antwoordsleutel als de ingedikte criterialijst zijn het meest adequaat om studentprestaties mee te beoordelen. In hoeverre de resultaten samenhangen met de inhoudsdeskundigheid van de beoordelaars was op basis van het pilot-onderzoek uiteraard niet te achterhalen.

Uit bovenstaande blijkt dat het pilot-onderzoek een aantal inhoudelijke vragen voor het hoofdonderzoek had opgeleverd. Zo was het de vraag of dezelfde resultaten zouden worden gevonden indien meer studenten en beoordelaars in het onderzoek werden betrokken. Eveneens moest de invloed van positieve weging op validiteit en betrouwbaar- 
heid worden bestudeerd. Daarnaast was het hoofdonderzoek van belang om de invloed van de interactie tussen de medische expertise van de beoordelaars en de mate van structurering van de beoordelingsmethode op de betrouwbaarheid te kunnen bestuderen.

De precieze vraagstellingen van het hoofdonderzoek en de beantwoording van deze gerezen vragen worden uitgebreid beschreven in het hiemavolgende hoofdstuk. 


\section{HET HOOFDONDERZOEK}

\subsection{Inleiding}

Op basis van de gegevens uit het pilot-onderzoek werd een aantal wijzigingen in het onderzoeksmateriaal aangebracht. Aangezien dit slechts minimale veranderingen betroffen, werd besloten het hoofdonderzoek uit te voeren.

In dit hoofdstuk worden de vraagstellingen, de procedure en de resultaten van het hoofdonderzoek beschreven. Het hoofdstuk wordt afgesloten met een korte beschrijving van de consequenties van de resultaten voor de hypothesen.

\subsection{Vraagstellingen}

In deze paragraaf worden de vraagstellingen beschreven die aan het onderzoek ten grondslag lagen. Bij de beschrijving wordt dezelfde indeling gehanteerd als in de voorafgaande hoofdstukken.

\section{Validiteit}

Vraagstelling 1.

Welke invloed heeft structurering van beoordelingsmethoden op de validiteit van gegeven beoordelingen voor antwoorden op een schriftelijk simulatie-instrument voor het meten van de vaardigheid in medisch probleemoplossen, dat gebruik maakt van korte antwoordvragen?

Vraagstelling 2.

Welke invloed heeft de deskundigheid c.q. medische expertise van de beoordelaar op de validiteit en in hoeverre wordt de relatie tussen medische expertise en de 
validiteit beïnvloed door de mate van structurering van de beoordelingsmethode?

Deze vraag valt in twee deelvragen uiteen:

2a. Wat is de invloed van medische expertise van de beoordelaars op de validiteit van de meting?

2b. Welke invloed heeft de interactie tussen de medische expertise van de beoordelaars en de mate van structurering van de beoordelingsmethode op de validiteit van de meting?

\section{Generaliseerbaarheidsanalyses}

Vraagstelling 3.

Wat is de invloed van de mate van structurering van de beoordelingsmethode op de betrouwbaarheid van een schriftelijk simulatie-instrument voor het meten van de vaardigheid in medisch probleemoplossen, dat gebruik maakt van korte antwoordvragen?

Deze vraagstelling valt in twee deelvragen uiteen:

3a. Welke invloed heeft de mate van structurering van de beoordelingsmethode op de mate waarin beoordelaarseffecten bijdragen aan de totale variantie van een meting (over alle vragen heen), vergeleken miet andere variantiebronnen?

3b. Welke invloed heeft de mate van structurering van de beoordelingsmethode op de interbeoordelaarsbetrouwbaarheid?

Vraagstelling 4.

Welke invloed heeft de deskundigheid c.q. medische expertise van de beoordelaar op de betrouwbaarheid en in hoeverre wordt de relatie tussen medische expertise en betrouwbaarheid beïnloed door de mate van structurering van de beoordelingsmethode?

Deze vraagstelling omvat een viertal deelvragen:

4a. Wat is de invloed van medische expertise van de beoordelaars op de interbeoordelaarsbetrouwbaarheid?

4b. Wat is de invloed van medische expertise van de beoordelaars op de totale betrouwbaarheid van de meting?

4c. Wat is de invloed van de interactie tussen de medische expertise van de beoordelaar en de mate van structurering van de beoordelingsmethode op de relatieve bijdrage van beoordelaarseffecten op de interbeoordelaarsbetrouwbaarheid?

4d. Wat is de invloed van de interactie tussen de medische expertise van de beoordelaar en de mate van structurering van de beoordelingsmethode op de relatieve bijdrage van beoordelaarseffecten op de totale betrouwbaarheid van een meting? 


\section{Weging}

Vraagstelling 5 .

Welke invloed heeft positieve weging op de validiteit van de beoordelingsmethoden?

\section{Waardering van de beoordelingsmethoden}

\section{Vraagstelling 6.}

Hoe worden de verschillende beoordelingsmethoden door de beoordelaars ervaren?

Deze vraagstelling bestaat uit twee deelvragen:

6a. Welke mate van structurering van de beoordelingsmethode wordt door de beoordelaars als het prettigst ervaren?

6b. Hangt de voorkeur voor een bepaalde mate van structurering van de beoordelingsmethode samen met de medische expertise van de beoordelaars?

Vraagstelling 7.

Hoe wordt de kwaliteit van de beoordelingsmethoden door de beoordelaars ervaren?

Deze vraagstelling omvat eveneens twee deelvragen:

7a. Welke beoordelingsmethode is volgens de beoordelaars het meest adequaat om de prestatie van de studenten te beoordelen?

7b. Hangt de voorkeur voor een bepaalde mate van structurering van de beoordelingsmethode samen met de medische expertise van de beoordelaars?

\subsection{Methode}

\subsubsection{Materialen}

In het hoofdonderzoek werden dezelfde, minimaal gewijzigde, acht casus gebruikt die in het pilot-onderzoek waren getest. Voor elke vraag werden dezelfde vier beoordelingsmethoden gehanteerd als in het pilot-onderzoek, zij het dat bij de gestructureerde beoordelingsmethoden enkele synoniemen waren toegevoegd en de verschillende categorieën van gewichten waren voorzien. Deze wegingsfactoren waren op inhoudelijke gronden gekozen (zie hoofdstuk 4), zodat een meer adequate beoordeling van de studentantwoorden kon worden gegeven. Om inzicht te verkrijgen in de satisfactie van de beoordelaars met betrekking tot de verschillende beoordelingsmethoden, werd van dezelfde vragenlijst gebruik gemaakt als in het pilot-onderzoek. De gebruikte casus, beoordelingsmethoden en vragenlijst zijn opgenomen in respectievelijk bijlage 1, bijlage 2 en bijlage 3 .

Naast de speciaal voor het onderzoek ontwikkelde materialen, werd in het hoofdonderzoek 
gebruik gemaakt van de behaalde resultaten op de voortgangstoets van december 1988 en december 1989, om de representativiteit van de studenten te toetsen en de validiteit van de onderzoeksmaterialen te bestuderen. De voortgangstoets is een kennistoets die bestaat uit een gestratificeerde steekproef van juist/onjuist/? vragen op het eindniveau van de basisarts, die vier keer per jaar aan alle studenten van de medische faculteit van de Rijksuniversiteit Limburg ter beantwoording wordt voorgelegd. Deze toets wordt bij de medische faculteit van de Rijksuniversiteit Limburg voor summatieve doeleinden gebruikt, zowel in de propaedeuse als in de doctoraaifase (Imbos, 1989; Van der Vleuten \& Verwijnen, 1990).

\subsubsection{Subjecten}

In het onderzoek werden 98 studenten geneeskunde van de Rijksuniversiteit Limburg betrokken om de vragen behorende bij de casuïstiek te beantwoorden. De studenten waren afkomstig uit drie jaargroepen: 18 eerstejaars-, 40 vierdejaars- en 40 zesdejaars studenten. Deze verdeling over jaargroepen werd aangebracht om op basis van hun resultaten de validiteit van de beoordelingsmethoden te kunnen bestuderen.

In het hoofdonderzoek werd een kleiner aantal eerstejaars studenten uitgenodigd de vragen te beantwoorden, omdat evenals in het pilot-onderzoek er van werd uitgegaan dat het niet zinvol zou zijn de antwoorden van de eerstejaars studenten in de generaliseerbaarheidsanalyse te betrekken. Aangezien de eerstejaars studenten voomamelijk ten behoeve van de validiteitsstudies aan het onderzoek deelnamen, werd om pragmatische redenen het aantal eerstejaars vastgesteld op 18.

Om de invloed van medische expertise te kunnen bestuderen, werden drie groepen beoordelaars met verschillende expertise samengesteld. Deze drie groepen bestonden uit respectievelijk 16 huisartsen uit de regio Limburg en Noord-Brabant, 16 vierdejaars studenten geneeskunde en 16 vierdejaars studenten economie van de Rijksuniversiteit Limburg. Verondersteld werd dat de huisartsen over de meeste expertise zouden beschikken. Hoewel vierdejaars studenten, in tegenstelling tot de huisartsen, nog geen praktijkervaring hadden, werd verondersteld dat zij over meer medische kennis zouden beschikken dan de economie studenten. Deze laatste groep studenten werd gezien als leken-beoordelaars, aangezien werd verondersteld dat zij weinig tot geen medische expertise zouden bezitten.

De keuze voor economie studenten kwam voort uit praktische overwegingen. Het leek op voorhand niet realiseerbaar voldoende docenten van een andere faculteit bereid te vinden om als beoordelaar in het onderzoek op te treden.

De werving van de huisartsen geschiedde via een oproep in een periodiek bulletin voor huisartsen. De 98 studenten die de vragen behorende bij de casuïstiek beantwoordden en de vierdejaars studenten geneeskunde en economie die als beoordelaars fungeerden, werden via een schriftelijk oproep in het faculteitsgebouw benaderd. Binnen twee weken na verschijning van de oproepen hadden voor beide activiteiten voldoende personen zich aangemeld.

Zowel de studenten die de vragen beantwoordden als de huisartsen en studenten die als beoordelaars optraden waren vrijwilligers en ontvingen een kleine financiële vergoeding. 


\subsubsection{Procedure}

Evenals in het pilot-onderzoek werden de casus onder standaard examencondities aan de eerste- en vierdejaars studenten geneeskunde aangeboden. De totale toetstijd betrof maximaal twee uur. De zesdejaars studenten werden wederom om praktische redenen met een uitgebreide schriftelijke en mondelinge toelichting in staat gesteld de vragen thuis te beantwoorden. Aan zowel de eerste-, de vierde- als de zesdejaars studenten werd de casus in verschillende volgorde aangeboden om sequentie-effecten te voorkomen.

Nadat alle studenten de vragen hadden beantwoord, werd bij de verspreiding van de antwoorden over de beoordelaars, eenzelfde procedure gevolgd als in het pilot-onderzoek. Het enige verschil was, dat in het hoofdonderzoek de ene helft van de beoordelaars de antwoorden van de eerste 49 studenten (9 eerste-, 20 vierde- en 20 zesdejaars studenten) nakeken, en de tweede helft van de beoordelaars de resterende 49 studenten beoordeelden. Dit werd gedaan om de benodigde nakijktijd van de beoordelaars te beperken, aangezien in het pilot-onderzoek was gebleken, dat de beoordelaars tussen de zes en acht uur nodig hadden om de antwoorden van 40 studenten te beoordelen.

Daarnaast moesten de beoordelaars, nadat ze 2 casus met één beoordelingsmethode hadden nagekeken, de benodigde nakijktijd noteren. Hiervoor was in het boekje met de beoordelingsmethoden na elke 2 casus een apart formulier opgenomen waarop de nakijktijd diende te worden opgeschreven.

Evenals in het pilot-onderzoek werden de beoordelaars verzocht de meegestuurde vragenlijst in te vullen.

\subsubsection{Statistische analyse}

Het was de bedoeling de resultaten van de studenten uit de drie jaargroepen op de casustoets te gebruiken als indicatie voor de theoretische validiteit. Dit was alleen mogelijk als zeker was, dat de studenten uit de drie jaargroepen ook representatief zouden zijn voor de totale jaargroep. Zodoende werd, nadat de benodigde 98 studenten zich hadden aangemeld, de representativiteit gecontroleerd.

Bij alle studenten van de medische faculteit wordt vier keer per jaar een voortgangstoets afgenomen. De resultaten op deze toets vormden de meest betrouwbare gegevens, op basis waarvan de representativiteit van de steekproeven kon worden bestudeerd. Voor de vergelijking werd gebruik gemaakt van de behaalde resultaten op de voortgangstoets van december 1988 omdat deze resultaten het meest recent waren. De grootte van de verschillen werden met een $\mathrm{F}$-toets op significantie onderzocht.

Evenals in het pilot-onderzoek vormde de gemiddelde procentuele score op de vragen behorende bij één casus de uiteindelijke casusscore. De toetsscore van een student kwam overeen met de gemiddelde score die de student op de acht casus had behaald. De casusscore en de toetsscore werden beide als input gebruikt bij de verschillende statistische analyses. Op de gegevens van alle drie de groepen beoordelaars werden dezelfde statistische analyses uitgevoerd als in het pilot-onderzoek. 


\subsubsection{Validiteit}

De validiteit van de beoordelingsmethoden werd evenals in het pilot-onderzoek onderzocht door de behaalde scores van de verschillende jaargroepen met elkaar te vergelijken en de correlatie tussen de verschillende beoordelingsmethoden te bepalen. Daarnaast werd per beoordelingsmethode een discriminant-analyse uitgevoerd. Hierbij werden de studenten op basis van de behaalde resultaten op de casustoets in een jaargroep geplaatst en werd deze voorspelde indeling vergeleken met de daadwerkelijke groepsindeling van de studenten. De mate waarin beide indelingen met elkaar overeenkwamen, werd gezien als een maat voor de validiteit van de beoordelingsmethoden.

Om de concurrente validiteit te onderzoeken werd per jaargroep de behaalde score op de casustoets gecorreleerd met de door de studenten behaalde resultaten op de voortgangstoets van december 1989. Als score op de voortgangstoets werd de behaalde goed-minusfout-score genomen. De keuze voor de decembertoets van 1989 kwam voort uit het feit dat deze toets in dezelfde periode werd afgenomen als de casustoets.

Tenslotte werd bij elke beoordelingsmethode het aantal geslaagden/gezakten bij een bepaalde cesuur bepaald en werden de resultaten van de verschillende beoordelingsmethoden met elkaar vergeleken. Voor de bepaling van de cesuur werd in eerste instantie getracht deze te laten bepalen door de constructeurs van de casus. Binnen deze groep was geen overeenstemming te verkrijgen, zodat werd besloten verschillende cesuren op systematische wijze te variëren. Gekozen werd voor een cesuur van $30 \%, 40 \%, 50 \%$ en $60 \%$ van de maximaal te behalen score.

\subsubsection{Generaliseerbaarheidsanalyses}

\section{G-studie}

In het hoofdonderzoek werd het in het pilot-onderzoek uitgeteste $\mathrm{p} x \mathrm{i} \mathrm{x}$ j-design gehanteerd. Hierbij vormde het hoofdeffect studenten (p) object van meting en werden de casus (i) en beoordelaars (j) als random facetten beschouwd. Aangezien in het hoofdonderzoek de beoordelaars slechts de helft van de studenten beoordeelden (zie 5.3.3) werd eerst voor de groep beoordelaars die dezelfde groep studenten hadden beoordeeld de variantiecomponenten op dezelfde wijze geschat als in het pilot-onderzoek. Vervolgens werden de variantiecomponenten gemiddeld over de twee groepen beoordelaars.

\section{D-studies}

Evenals in het pilot-onderzoek werden in het hoofdonderzoek een aantal D-studies uitgevoerd. Allereerst werd de interbeoordelaarsbetrouwbaarheid geschat met de formule zoals beschreven in paragraaf 4.2 .

Daarnaast werd een tweetal D-studies uitgevoerd voor de schatting van de totale toetsbetrouwbaarheid waarin zowel de invloed van de toetslengte als het aantal beoordelaars op de generaliseerbaarheid van de scores werd onderzocht. Object van meting vormden de personen en generalisering vond plaats naar $\mu_{\mathrm{p}}$.

De eerste D-studie werd uitgevoerd onder de aanname dat alle beoordelaars alle studentantwoorden beoordeelden (een volledig gekruist $\mathrm{p} \times \mathrm{i} \times \mathrm{j}$-design). Bij de berekening van de generaliseerbaarheidscoëfficiënten werd gebruik gemaakt van de formule die in 
paragraaf 4.2 is beschreven.

In de tweede $\mathrm{D}$-studie werd uitgegaan van een meer praktische situatie waarin elke beoordelaar slechts de vragen behorende bij één casus voor alle studenten beoordeelde ( $p$ $\mathrm{x}$ (j:i)-design). Bij een norm georiënteerd perspectief wordt voor dit $\mathrm{p} x \mathrm{j}: \mathrm{i}$-design de generaliseerbaarheidscoëfficiënt als volgt berekend (Cronbach et al., 1972):

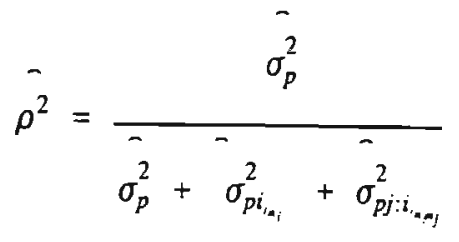

$\hat{\rho^{2}}=$ generaliseerbaarheidscoëfficiënt

$-$

$\sigma^{2}=$ geschatte variantie

$p=$ personen

$i=$ item

$j=$ beoordelaar

$n_{i}=$ aantalitems

$n_{j}=$ aantal beoordelaars

Beide D-studies werden eveneens uitgevoerd vanuit een domein georiënteerd perspectief, waarbij de scores een absolute waarde hebben ten opzichte van een standaard. Dit betekent dat bij de berekening van de betrouwbaarheid alle variantiecomponenten worden opgenomen, die zowel de rangorde als het absolute niveau kunnen verstoren (Cronbach et al., 1972). De volgende formule werd gehanteerd voor het berekenen van de totale betrouwbaarheid bij het gekruist design onder een domein georiënteerd perspectief:

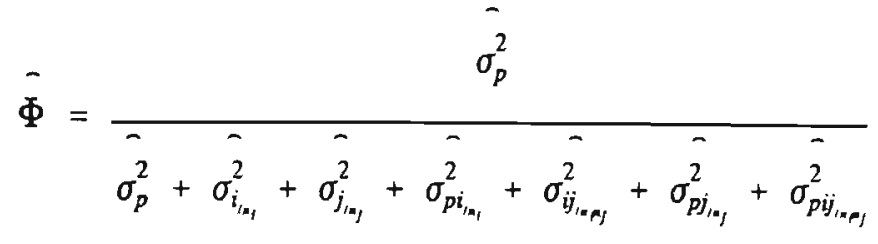

$\hat{\phi}=$ coëfficiënt phi

-

$\mathbf{0}^{2}=$ geschatte variantie

$p=$ personen

$i=$ item

$j=$ beoordelaar

$n_{i}=$ aantalitems

$n_{j}=$ aantal beoordelaars 
De totale betrouwbaarheid bij een genest design onder een domein georiënteerd perspectief, werd berekend met behulp van de volgende formule:

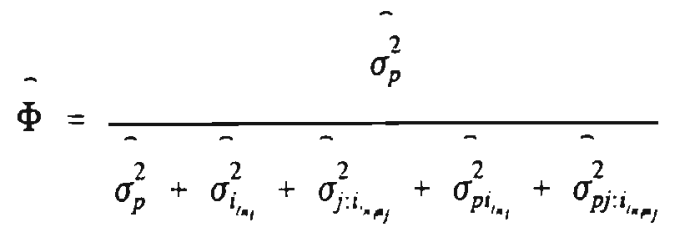

$$
\begin{aligned}
\hat{\phi} & =\text { coëfficiënt phi } \\
\hat{\sigma^{2}} & =\text { geschatte variantie } \\
p & =\text { personen } \\
\hat{i} & =\text { item } \\
j & =\text { beoordelaar } \\
n_{i} & =\text { aantalitems } \\
n_{j} & =\text { aantal beoordelaars }
\end{aligned}
$$

Bij een betrouwbare meting is de standaardmeetfout klein, terwijl bij een onbetrouwbare meting de standaardmeetfout groot is. Op basis van de standaardmeetfout is het mogelijk een betrouwbaarheidsinterval te schatten, waarmee kan worden aangegeven met welke zekerheid de score van een persoon binnen het interval zal liggen.

In het geval dat alleen de betrouwbaarheid van de scores wordt beschouwd, is de consequentie van de meetfout voor alle personen gelijk. Bij het nemen van een zak/slaagbeslissing is dit echter niet het geval. De betrouwbaarheid van een dergelijke beslissing hangt mede af van het verschil tussen de behaalde score en de cesuur. Indien de cesuur binnen het interval van de standaardmeetfout ligt, is niet met grote zekerheid vast te stellen of deze persoon terecht slaagt. Naarmate de score verder boven of onder de cesuur ligt, neemt de betrouwbaarheid van de genomen beslissing toe.

De standaardmeetfout is bij korte toetsen relatief groot. Afhankelijk van de gekozen cesuur kunnen al dan niet betrouwbare zak/slaag-beslissingen worden genomen. Naarmate de cesuur dichter bij de gemiddeld behaalde score komt te liggen, neemt de betrouwbaarheid van de zak/slaag-beslissing af.

In het hoofdonderzoek werd een D-studie uitgevoerd waarin per jaargroep en voor elke beoordelingsmethode de betrouwbaarheid van de examenbeslissing bij verschillende cesuren werd bepaald. De betrouwbaarheidsanalyses werden uitgevoerd bij cesuren van $30 \%, 40 \%, 50 \%$ en $60 \%$ van de maximaal te behalen score. De berekeningen vond plaats 
aan de hand van de volgende formule (Brennan, 1983):

$$
\phi(\lambda)=\frac{\sigma_{p}^{2}+(\mu-\lambda)}{\sigma_{p}^{2}+(\mu-\lambda)^{2}+\sigma_{\Delta}^{2}}
$$

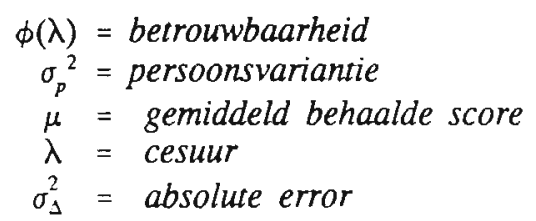

\subsubsection{Weging}

In het hoofdonderzoek waren de categorieën van de gestructureerde beoordelingsmethoden van wegingsfactoren voorzien. Om de invloed van positieve weging op validiteit te kunnen bestuderen, werden de scores omgezet in scores die op basis van een ongedifferentieerde weging zouden worden verkregen. Hiertoe werd voor elke categorie het maximaal aantal toe te kennen punten gelijkgesteld aan 100 en werden de gegeven oordelen op dezelfde wijze omgerekend. Een score van bijvoorbeeld 25 punten op een categorie waarvoor maximaal 250 punten mocht worden gegeven, leverde bij een ongedifferentieerde weging 10 punten op. De casusscore en de totale toetsscore werd op dezelfde wijze berekend als hiervoor beschreven.

Voor de ongewogen scores werden het gemiddelde en de bijbehorende standaarddeviatie berekend. Deze werden vergeleken met het gemiddelde en de standaarddeviatie van de gewogen scores. Daarnaast werd met behulp van een Pearson correlatie de correlaties tussen de gewogen en de ongewogen scores voor de drie gestructureerde beoordelingsmethoden bepaald.

\subsection{Verwachtingen}

\subsubsection{Validiteit}

In het hoofdonderzoek werden dezelfde casus gebruikt als in het pilot-onderzoek. De gegevens uit het pilot-onderzoek vormden een indicatie voor de validiteit van de casus. Op basis van deze gegevens werd verwacht, dat in het hoofd-onderzoek de behaalde score op de casustoets zou toenemen naarmate de studenten meer medisch onderwijs hadden gevolgd.

Evenals in het pilot-onderzoek werd verwacht, dat met de gestructureerde beoordelingsmethoden meer valide uitspraken zouden worden verkregen. Op basis hiervan werd verondersteld dat de correlaties tussen het vrije oordeel en de gestructureerde beoordelingsmethoden lager zouden zijn dan de correlaties tussen de drie gestructureerde beoordelingsmethoden. Wat betreft de hoogte van de correlatie werd verwacht dat de 
correlatie tussen het vrije oordeel en de gestructureerde beoordelingsmethoden gelijk zou zijn aan de interbeoordelaarsbetrouwbaarheid bij het vrije oordeel.

De validiteit van de beoordelingsmethoden werd verder onderzocht door per beoordelingsmethode een discriminant-analyse uit te voeren. Verwacht werd dat met de gestructureerde beoordelingsmethoden meer valide uitspraken konden worden gedaan, zodat de voorspelde groepsindeling op basis van de gestructureerde beoordelingsmethoden beter zou zijn dan op basis van het vrije oordeel. Aangezien bij de inhoudsdeskundige beoordelaars bij de korte antwoordsleutel en de ingedikte criterialijst op de minste beoordelaarseffecten werd gerekend, was de verwachting dat met beide methoden het beste onderscheid tussen personen met verschillende medische competentie zou worden aangebracht. Bij de economie studenten werd daarentegen verwacht, dat de validiteit van de beoordelingen zou toenemen naarmate de beoordelingsmethode meer was gestructureerd.

Met betrekking tot de hoogte van de gegeven scores werd eenzelfde beeld verwacht als in het pilot-onderzoek: de score neemt af naarmate de beoordelingsmethode meer gestructureerd is. Uitgaande van deze trend werd aangenomen, dat het aantal geslaagden het grootst zou zijn bij het vrije oordeel en de minste studenten zouden slagen bij de uitgebreide criterialijst, ongeacht de gehanteerde cesuur $(30 \%, 40 \%, 50 \%$ of $60 \%)$.

Naar aanleiding van de resultaten van het pilot-onderzoek werd besloten de validiteit van de beoordelingsmethoden ondermeer te onderzoeken met behulp van een extern criterium. Zodoende werd in het hoofdonderzoek de correlatie bepaald tussen resultaten op de casustoets en de behaalde score op de voortgangstoets van december 1989. Aangezien de voortgangstoets een kennistoets is en de casustoets tot doel had vaardigheid in medisch probleemoplossen te meten, zou kunnen worden verondersteld, dat de correlatie tussen beide scores relatief laag zou zijn. Een dergelijk resultaat zou dan kunnen worden opgevat als een indicatie voor divergente validiteit. Deze veronderstelling werd eveneens gehanteerd door De Graaff (1989), die de lage correlaties tussen een soortgelijke casustoets en de behaalde resultaten op een voortgangstoets als een bevestiging voor de divergente validiteit opvatte.

Aan de andere kant is bekend. dat er een sterke relatie bestaat tussen medisch probleemoplossen en de medische kennis waarover een persoon beschikt (Elstein et al., 1978; Van der Vleuten, 1991). Op basis hiervan zou kunnen worden verondersteld, dat de correlatie tussen de resultaten op de voortgangstoets en de resultaten op de casustoets hoog zou zijn. Kortom. met betrekking tot de correlatie tussen beide scores was op voorhand geen eenduidige verwachting te formuleren. Het bepalen van de correlaties had met name exploratieve doeleinden. Wellicht dat op basis van mogelijke differentiële effecten tussen de verschillende beoordelingsmethoden meer inzicht kon worden verkregen in de oorzaak van de correlaties tussen de beoordelingsmethoden, zoals gevonden in het pilot-onderzoek.

\subsubsection{Generaliseerbaarheidsanalyses}

\subsubsection{G-studie}

Een toets wordt regelmatig gebruikt om te achterhalen in hoeverre personen zich bepaalde kennis en/of vaardigheden hebben eigen gemaakt. Niet elk persoon zal de kennis en/of vaardigheden even goed beheersen, zodat door middel van de toets een onderscheid tussen personen wordt aangebracht. Op basis van deze redenering werd aangenomen dat bij een 
meer valide beoordelingsmethode een grotere variantiecomponent voor het hoofdeffect personen (p) zou worden gevonden dan bij een minder valide methode. Voorafgaande aan het onderzoek werd verwacht dat de gestructureerde beoordelingsmethoden tot meer accurate en zodoende meer valide beoordelingen zouden leiden dan het vrije oordeel. Hoewel in het pilot-onderzoek bij de verschillende beoordelingsmethoden weinig tot geen verschillen werden gevonden in de grootte van de variantie-component voor het p-effect, werd nog steeds verwacht dat in het hoofdonderzoek een grotere p-component zou worden gevonden bij de gestructureerde methoden dan bij het vrije oordeel.

Voorafgaande aan het onderzoek werd aangenomen, dat per definitie verschillen zouden bestaan in de moeilijkheidsgraad van de verschillende casus. Deze variatie in moeilijkheidsgraad leidt tot verschillende gemiddelde scores voor de casus. Deze verschillen komen tot uitdrukking in de grootte van de variantiecomponent behorende bij het hoofdeffect casus (i); hoe meer verschillen in de moeilijkheidsgraad van de casus des te groter is de variantiecomponent. Uitgaande van de veronderstelling dat met de gestructureerde beoordelingsmethoden meer valide beoordelingen zouden worden verkregen, werd verwacht dat de variantiecomponent voor het hoofdeffect casus bij deze beoordelingsmethoden groter zou zijn dan bij het vrije oordeel. Deze veronderstelling kwam voort uit de gedachte dat met een meer valide beoordelingsmethode de werkelijke verschillen tussen casus meer zichtbaar zouden worden.

Met betrekking tot de systematische verschillen tussen beoordelaars (j) was in het pilotonderzoek geen duidelijke trend waarneembaar, hoewel deze component het kleinst was bij de uitgebreide criterialijst. Toch werd van de eerdere verwachtingen uitgegaan, dat de verschillen tussen de beoordelaars het kleinst zouden zijn bij de korte antwoordsleutel en de ingedikte criterialijst, terwijl bij het vrije oordeel de minste overeenstemming zou worden gevonden. Een mogelijke uitzondering op deze regel zou kunnen worden gevormd door de economie studenten. Door hun tekort aan medische expertise zouden zij het meest gebaat kunnen zijn bij de vergaande detaillering van de uitgebreide criterialijst.

Het pilot-onderzoek had laten zien dat de inconsistentie van de beoordelaars over casus en/of personen het grootst was voor het vrije oordeel en dat deze het kleinst was voor de uitgebreide criterialijst. Hoewel niet kon worden geconcludeerd dat de inconsistentie afnam bij een toenemende structurering van de beoordelingsmethode, werd uitgaande van eerdere veronderstellingen, in het hoofdonderzoek wel op een dergelijke trend gerekend.

In de onderzoeken naar instrumenten voor het meten van de vaardigheid in medisch probleemoplossen wordt steeds geconstateerd dat de behaalde score op de ene casus een geringe voorspellende waarde heeft wat betreft de te verwachten score op een andere casus. Op dit probleem van de inhoudsspecificiteit werd ook gerekend in het onderhavige onderzoek. Vandaar dat bij alle beoordelingsmethoden een hoge variantiecomponent voor het interactie-effect pi werd verwacht.

Voorts werd er op gerekend dat door het bieden van structuur de invloed van toevalsfactoren zou afnemen. Hierdoor zou het grootste gedeelte van de variantie kunnen worden verklaard door de factoren ( $p$, $i$ en $j$ ) en de interactie tussen de factoren ( $p i$, pj en ij) die in het onderzoek waren betrokken. Hoewel verwacht werd dat de beoordelaarseffecten bij de inhoudsdeskundige beoordelaars iets groter zouden zijn bij de uitgebreide criterialijst dan bij de twee andere gestructureerde beoordelingsmethoden, werd er van uitgegaan dat de error-term (pij) kleiner zou worden naarmate de beoordelingsmethode meer gestructureerd werd, ongeacht de medische competentie van de beoordelaars. 


\subsubsection{D-studie}

In het pilot-onderzoek werden relatief lage interbeoordelaarsbetrouwbaarheden gevonden voor alle vier de beoordelingsmethoden. Overeenkomstig de verwachtingen was de interbeoordelaarsbetrouwbaarheid het laagst voor het vrije oordeel. Tussen de gestructureerde beoordelingsmethoden werden echter geen duidelijke verschillen gevonden. In het hoofdonderzoek werd eveneens gerekend op een lage interbeoordelaarsbetrouwbaarheid voor het vrije oordeel, maar werd tevens verondersteld dat de hoogte van de interbeoordelaarsbetrouwbaarheid bij de gestructureerde beoordelingsmethoden zou verschillen per groep beoordelaars. Zo werd er van uitgegaan dat bij de huisartsen en de vierdejaars geneeskunde studenten de hoogste interbeoordelaarsbetrouwbaarheid zou worden gevonden bij de korte antwoordsleutel en de ingedikte criterialijst. Dit vanwege het feit dat werd verwacht dat voor beide groepen beoordelaars de uitgebreide criterialijst te gedetailleerd zou zijn en beoordelaarseffecten zou induceren. Bij de economie studenten werd gerekend op een stijgende interbeoordelaarsbetrouwbaarheid bij een toenemende structurering van de beoordelingsmethode.

Met betrekking tot de totale betrouwbaarheid werd in het pilot-onderzoek geconstateerd, dat de structurering van de beoordelingsmethoden hierop geen duidelijke invloed had. De invloed van andere foutenbronnen leken dusdanig groot te zijn dat deze de verschillen tussen beoordelaars overtrof, waardoor weinig tot geen verschillen tussen de beoordelingsmethoden werden gevonden. Ondanks deze bevindingen werd in het hoofdonderzoek gerekend op de hoogste totale betrouwbaarheid bij de korte antwoordsleutel en de ingedikte criterialijst bij de inhoudsdeskundige beoordelaars. Voor de economie studenten werd de hoogste totale betrouwbaarheid verwacht bij de uitgebreide criterialijst (zie hoofdstuk 3 voor de rationale).

$\mathrm{Bij}$ een domein georiënteerd perspectief worden alle variantiecomponenten die zowel de rangorde als het absolute niveau van de personen beïnvloeden in de berekening van de error variantie meegenomen. Hierdoor wordt uiteraard de totale betrouwbaarheid lager dan bij een norm georiënteerd perspectief. Uitgaande van de veronderstelling dat de icomponent zou stijgen bij de gestructureerde beoordelingsmethoden, werd verwacht dat de totale betrouwbaarheid bij de gestructureerde beoordelingsmethoden meer zou afnemen dan bij het vrije oordeel.

Naarmate de cesuur dichter bij de gemiddelde toetsscore ligt, zal de betrouwbaarheid van een zak/slaag-beslissing afnemen. Aangezien werd verwacht dat de gemiddelde score zou variëren per jaargroep en per beoordelingsmethode, werd gerekend op een zeer gedifferentieerde interactie tussen de hoogte van de cesuur en beoordelingsmethode op de betrouwbaarheid van de genomen beslissing. Wel werd verwacht dat de betrouwbaarheid van de beslissing bij eenzelfde cesuur sterk zou variëren bij de verschillende beoordelingsmethoden, als gevolg van de verwachte verschillen in de gemiddelde score tussen de vier beoordelingsmethoden.

\subsubsection{Weging}

Het toepassen van één of andere vorm van gedifferentieerde weging komt met name voort uit de behoefte van beoordelaars om bepaalde aspecten zwaarder in een beoordeling mee te laten tellen dan andere aspecten. Verwacht werd dat de beoordelaars de positieve weging in de gestructureerde beoordelingsmethoden zouden waarderen, hetgeen de face- 
validity van de gestructureerde beoordelingsmethoden zou verhogen. Daarnaast werd verondersteld, dat de aangebrachte wegingsfactoren het discriminerend vermogen van de gestructureerde beoordelingsmethoden zou doen toenemen, doordat de wegingsfactoren de scores van de goede en slechte studenten meer uit elkaar zouden trekken. Voorts werd verwacht dat door het verminderd discriminerend vermogen de correlatie tussen de gestructureerde beoordelingsmethoden bij de ongewogen scores hoger zou zijn dan de correlatie tussen de gestructureerde beoordelingsmethoden, uitgaande van de gewogen scores. Eenzelfde beeld werd verwacht met betrekking tot de correlatie tussen het vrije oordeel en de gestructureerde beoordelingsmethoden.

\subsubsection{Waardering van de beoordelingsmethoden}

Op basis van eerder onderzoek (Cough, 1962; Wiggins, 1973; Nisbett \& Ross, 1980) werd voorafgaande aan het onderzoek verondersteld, dat de inhoudsdeskundige beoordelaars de korte antwoordsleutel en de ingedikte criterialijst het prettigst zouden vinden om mee te beoordelen. Deze verwachting werd in het pilot-onderzoek bevestigd, zodat ook in het hoofdonderzoek een dergelijk resultaat werd verwacht.

In de gerapporteerde studies werd voomamelijk gebruik gemaakt van inhoudsdeskundige beoordelaars. Op basis van deze studies is het niet mogelijk te achterhalen in hoeverre een relatie bestaat tussen de inhoudsdeskundigheid van de beoordelaar en de gewenste mate van structurering. Intuïtief lijkt verondersteld te mogen worden dat niet inhoudsdeskundige beoordelaars meer gestructureerde beoordelingsmethoden zouden prefereren, daar deze methoden het meest tegemoet komen aan hun gebrek aan expertise. Uitgaande van deze redenering werd verondersteld dat de economie studenten de uitgebreide criterialijst het prettigst zouden vinden om mee te beoordelen. Voorts werd verwacht dat de waardering voor de beoordelingsmethode zou afnemen naarmate de beoordelingsmethode minder structuur bood.

Wat betreft de waardering van de beoordelaars voor de geschiktheid van de verschillende beoordelingsmethoden voor het beoordelen van de antwoorden werd nagenoeg eenzelfde beeld verwacht; de inhoudsdeskundige beoordelaars vinden de korte antwoordsleutel en de ingedikte criterialijst het meest adequaat, terwijl de economie studenten alle drie de gestructureerde beoordelingsmethoden doeltreffend vinden. De verwachting dat de economie studenten eveneens de korte antwoordsleutel en de ingedikte criterialijst adequaat zouden vinden kwam voort uit de veronderstelling dat de beoordelaars deze vraag niet alleen vanuit hun eigen referentiekader zouden beantwoorden, maar de vraag meer algemeen zouden opvatten ("Denkt $u$ dat het mogelijk is met behulp van deze beoordelingsmethoden adequate beoordelingen te gegeven?").

\subsection{Hypothesen}

Op grond van de verwachtingen werd een aantal hypothesen geformuleerd, die in het hoofdonderzoek werden getoetst. In deze paragraaf worden de hypothesen beschreven.

\section{Validiteit}

1. De behaalde score op de casustoets is hoger naarmate de studenten meer medisch 
onderwijs hebben gevolgd.

2. De gemiddelde score op de casustoets neemt af naarmate de beoordelingsmethode meer is gestructureerd.

3. De verschillen tussen de jaargroepen zijn bij de gestructureerde beoordelingsmethoden meer geprononceerd dan bij het vrije oordeel.

4. Bij de inhoudsdeskundige beoordelaars leiden de korte antwoordsleutel en de ingedikte criterialijst tot de hoogste percentage juiste classificaties bij de discriminant-analyse.

5. Bij de economie studenten leidt de uitgebreide criterialijst tot de hoogste percentage juiste classificaties bij de discriminant-analyse.

6. Het vrije oordeel leidt tot het laagste percentage juiste classificaties bij de discriminant-analyse, ongeacht de medische expertise van de groep beoordelaars.

7. De correlaties tussen het vrije oordeel en de gestructureerde beoordelingsmethoden zijn lager dan de correlaties tussen de drie gestructureerde beoordelingsmethoden onderling.

\section{Generaliseerbaarheidsanalyses}

\section{G-studie}

8. De variantiecomponent behorende bij het hoofdeffect personen (p) is groter bij de gestructureerde beoordelingsmethoden dan bij het vrije oordeel.

9. De variantiecomponent behorende bij het hoofdeffect casus (i) is groter bij de gestructureerde beoordelingsmethoden dan bij het vrije oordeel.

10. De variantiecomponent behorende bij het hoofdeffect beoordelaars (j) is het grootst bij het vrije oordeel, ongeacht de medische expertise van de groep beoordelaars.

11. De variantiecomponent behorende bij het hoofdeffect beoordelaars is het kleinst bij de korte antwoordsleutel en de ingedikte criterialijst, bij de inhoudsdeskundige beoordelaars.

12. De variantiecomponent behorende bij het hoofdeffect beoordelaars is het kleinst bij de uitgebreide criterialijst voor de economie studenten.

13. De inconsistentie van beoordelaars over personen neemt af naarmate de beoordelingsmethode meer gestructureerd is, ongeacht de medische expertise van de groep beoordelaars.

14. De inconsistentie van beoordelaars over casus neemt af naarmate de beoordelingsmethode meer is gestructureerd, ongeacht de medische expertise van de groep beoordelaars.

15. Het pi-effect is relatief groot bij elke beoordelingsmethode.

16. De algemene error-variantie (pij) neemt af naarmate de beoordelingsmethode meer is gestructureerd, ongeacht de medische expertise van de groep beoordelaars.

\section{Interbeoordelaarsbetrouwbaarheid}

17. De interbeoordelaarsbetrouwbaarheid is het laagst voor het vrije oordeel, ongeacht de medische expertise van de groep beoordelaars.

18. De interbeoordelaarsbetrouwbaarheid voor de huisartsen is het hoogst bij de korte 
antwoordsleutel en de ingedikte criterialijst.

19. De interbeoordelaarsbetrouwbaarheid voor de geneeskunde studenten is het hoogst bij de korte antwoordsleutel en de ingedikte criterialijst.

20. Bij de economie studenten neemt de interbeoordelaarsbetrouwbaarheid toe naarmate de beoordelingsmethode meer is gestructureerd.

\section{Totale betrouwbaarheid}

21. De totale betrouwbaarheid is het hoogst bij de korte antwoordsleutel en de ingedikte criterialijst voor de inhoudsdeskundige beoordelaars.

22. De totale betrouwbaarheid is het hoogst bij de uitgebreide criterialijst voor de economie studenten.

23. Bij een domein georiënteerd perspectief is de daling van de totale betrouwbaarheid groter bij de gestructureerde beoordelingsmethoden dan bij het vrije oordeel, in vergelijking met een norm georiënteerd perspectief.

\section{Zak/slaag-beslissing}

24. Het aantal studenten dat slaagt voor de casustoets is het grootst bij het vrije oordeel en het kleinst bij de uitgebreide criterialijst, ongeacht de gehanteerde cesuur.

25. Naarmate de beoordelingsmethode meer is gestructureerd, neemt de betrouwbaarheid van de zak/slaag-beslissing af indien een lage censuur ( $30 \%$ en $40 \%$ ) wordt gehanteerd.

\section{Weging}

26. Het discriminerend vermogen van de gestructureerde beoordelingsmethoden neemt toe door het aanbrengen van positieve wegingsfactoren.

27. De correlatie tussen de gestructureerde beoordelingsmethoden is groter op basis van de ongewogen scores dan op basis van de gewogen scores.

28. De correlaties tussen het vrije oordeel en de gestructureerde beoordelingsmethoden is hoger bij de ongewogen scores dan bij de gewogen scores.

\section{Waardering van de beoordelingsmethoden}

29. De korte antwoordsleutel en de ingedikte criterialijst worden door de deskundige beoordelaars als het prettigst ervaren.

30. De uitgebreide criterialijst wordt door de economie studenten als het prettigst ervaren.

31. De inhoudsdeskundige beoordelaars vinden dat de antwoorden van de studenten het meest adequaat kunnen worden beoordeeld met de korte antwoordsleutel en de ingedikte criterialijst.

32. De economie studenten vinden alle drie de gestructureerde beoordelingsmethoden even adequaat om de prestaties van de studenten te beoordelen. 


\subsection{Resultaten}

\subsubsection{Representativiteit van de steekproef}

Voordat de studenten werden uitgenodigd om de vragen bij de casuïstiek te beantwoorden, werd de representativiteit van de steekproef geschat. Hiertoe werd een variantie-analyse uitgevoerd op de voortgangstoetsresultaten van december 1988, waarbij de studenten die zich hadden ingeschreven voor het experiment werden vergeleken met hun jaargenoten. De representativiteit werd getoetst met een F-toets. De resultaten worden weergegeven in tabel 5.1.

Tabel 5.1: Resultaten van de F-toets uitgevoerd op de behaalde goed-minus-fout score op de voortgangstoets van december 1988 , ter controle van de representativiteit van de steekproef.

\begin{tabular}{|c|c|c|c|c|c|c|c|c|}
\hline \multirow[t]{2}{*}{ jaargroep } & \multicolumn{3}{|c|}{ jaargroep } & \multicolumn{3}{|c|}{ steekproef } & \multirow[b]{2}{*}{ F-ratio } & \multirow[b]{2}{*}{$p$} \\
\hline & $\mathrm{N}$ & Gem. & Sd. & $N$ & Gem. & Sd. & & \\
\hline 1 & 165 & 4.09 & 0.27 & 18 & 4.83 & 0.61 & 0.91 & 0.34 \\
\hline 4 & 156 & 24.34 & 7.29 & 40 & 25.58 & 6.76 & 0.49 & 0.48 \\
\hline 6 & 119 & 37.35 & 8.40 & 40 & 37.66 & 8.74 & 0.29 & 0.86 \\
\hline
\end{tabular}

Tabel 5.1 laat zien dat de steekproeven in alle gevallen, wat betreft de behaalde score op de voortgangstoets, niet significant verschilden van de totale jaargroep. Op basis van deze gegevens werd geconcludeerd, dat wat kennis betreft de steekproef representatief was voor de jaargroepen, zodat in dit opzicht niet van een specifieke selectiebias sprake leek te zijn.

\subsubsection{Validiteit}

De relatie tussen de behaalde scores op de casustoets en het aantal jaren gevolgd medisch onderwijs werd als maat genomen voor de theoretische validiteit. Voor elke jaargroep zijn de gemiddelde score en de bijbehorende standaarddeviatie per beoordelingsmethode opgenomen in tabel 5.2. Grafisch worden de resultaten weergegeven in de figuren $5.1 \mathrm{t} / \mathrm{m}$ 5.3 .

Uit de resultaten bleek dat binnen elke jaargroep een redelijke spreiding in de behaalde scores aanwezig was. De mate van spreiding bleek echter te variëren per beoordelingsmethode, per jaargroep en per beoordelaarsgroep.

De huisartsen brachten met het vrije oordeel meer variatie in de geobserveerde scores bij de eerstejaars studenten aan dan met de gestructureerde beoordelingsmethoden. Deze trend was eveneens waarneembaar bij de andere twee groepen beoordelaars, zij het dat de spreiding toenam naarmate de beoordelaar minder inhoudsdeskundig was. Bij de scores van de vierdejaars studenten bleek eveneens dat de spreiding het grootst was met het vrije 
oordeel, ongeacht de medische expertise van de beoordelaars. Bij de scores van de zesdejaars studenten was een afwijkende trend waameembaar. De huisartsen bleken met de gestructureerde beoordelingsmethoden een grotere spreiding in de scores aan te brengen dan met het vrije oordeel. De geneeskunde studenten en de economie studenten brachten bij de zesdejaars studenten met elke beoordelingsmethode nagenoeg eenzelfde spreiding aan.

Met alle beoordelingsmethoden werd een hogere gemiddelde score gevonden naarmate de studenten meer onderwijs hadden gevolgd, ongeacht de medische expertise van de beoordelaars. Voor alle beoordelaars gold dat met de minst gestructureerde beoordelingsmethode gemiddeld de hoogste score werd gegeven, terwijl met de uitgebreide criterialijst de gemiddelde score het laagst was. Dit effect was echter het sterkst waarneembaar bij de economie studenten, die bij het vrije oordeel gemiddeld tien punten meer toekenden dan de twee andere groepen beoordelaars.

Tabel 5.2: Gemiddelde scores en standaarddeviaties per beoordelingsmethode voor elke jaargroep uitgesplitst per groep beoordelaars.

\begin{tabular}{|c|c|c|c|c|c|c|}
\hline \multirow[t]{3}{*}{ Beoordelingsmethode } & \multicolumn{6}{|c|}{ Jaargroep } \\
\hline & \multicolumn{2}{|c|}{1} & \multicolumn{2}{|c|}{4} & \multicolumn{2}{|c|}{6} \\
\hline & Gem. & Sd. & Gem. & Sd. & Gem. & Sd. \\
\hline & \multicolumn{6}{|c|}{ huisarsen als beoordelaars } \\
\hline vrije oordeel & 22.38 & 11.60 & 50.62 & 18.03 & 57.78 & 11.08 \\
\hline korte antwoord sleutel & 14.60 & 5.86 & 37.62 & 15.41 & 49.83 & 16.29 \\
\hline ingedikte crit. & 12.27 & 6.60 & 36.72 & 15.39 & 45.58 & 15.53 \\
\hline uitgebreide crit. & 9.67 & 8.26 & 30.88 & 16.99 & 41.98 & 16.48 \\
\hline
\end{tabular}

geneeskunde studenten als beoordelaars

$\begin{array}{lrrrrrr}\text { vrije oordeel } & 24.85 & 13.27 & 52.19 & 17.97 & 57.65 & 12.71 \\ \text { korte antwoord sleutel } & 12.75 & 6.95 & 36.79 & 13.82 & 48.15 & 9.92 \\ \text { ingedikte crit. } & 13.49 & 7.49 & 35.73 & 14.93 & 47.55 & 15.16 \\ \text { uitgebreide crit. } & 10.36 & 6.28 & 31.81 & 14.01 & 42.79 & 13.52\end{array}$

economie studenten als beoordelaars

$\begin{array}{lrrrrrr}\text { vrije oordeel } & 34.08 & 21.15 & 60.95 & 17.56 & 68.83 & 13.49 \\ \text { korte antwoord sleutel } & 15.65 & 8.53 & 35.20 & 13.96 & 43.47 & 12.92 \\ \text { ingedikte crit. } & 12.22 & 5.33 & 32.10 & 12.22 & 40.44 & 12.33 \\ \text { uitgebreide crit. } & 11.57 & 7.23 & 31.57 & 13.58 & 40.88 & 14.91\end{array}$




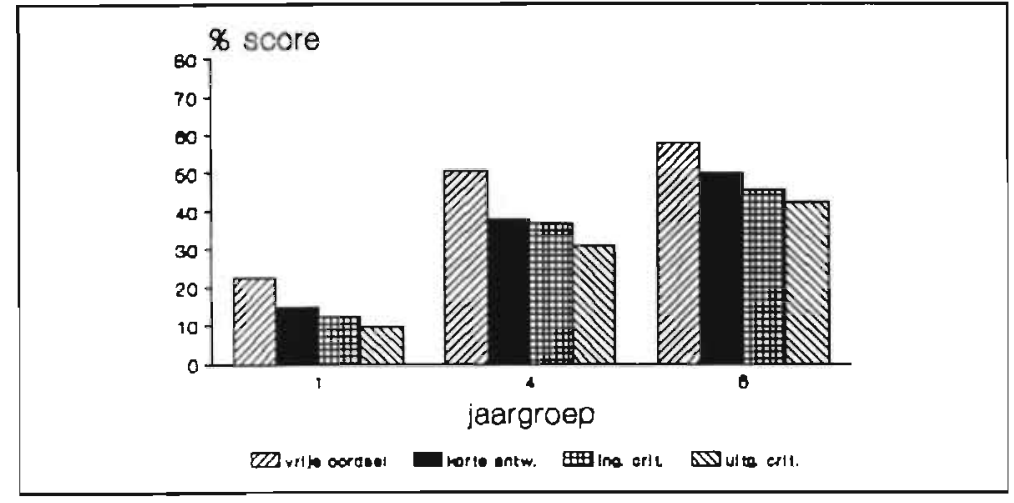

Figuur 5.1: Gemiddelde score voor elke jaargroep per beoordelingsmethode, toegekend door de huisartsen als beoordelaars.

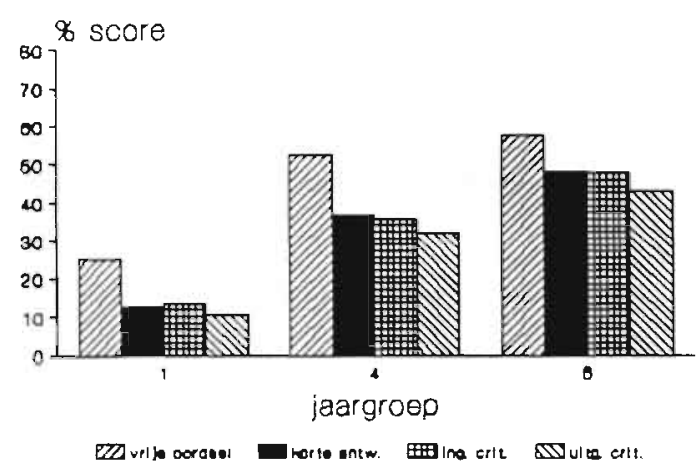

Figuur 5.2: Gemiddelde score voor elke jaargroep per beoordelingsmethode, toegekend door de geneeskunde studenten als beoordelaars.

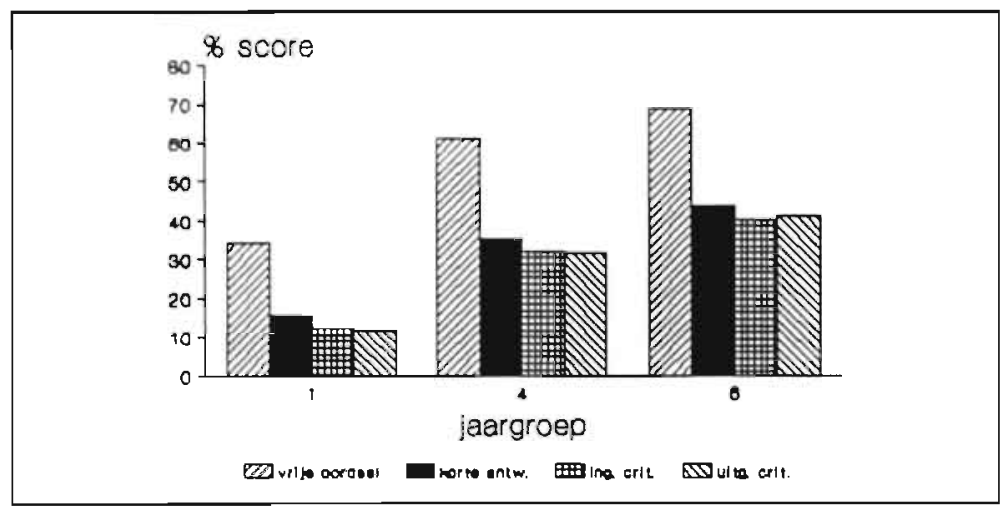

Figuur 5.3: Gemiddelde score voor elke jaargroep per beoordelingsmethode. toegekend door de economie studenten als beoordelaars. 
Om het onderscheidend vermogen van de beoordelingsmethoden verder te onderzoeken, werd bij elke groep beoordelaars een discriminant-analyse uitgevoerd op de behaalde scores. De mate waarin de groepsindeling op basis van de resultaten overeenkwam met de daadwerkelijke groepsindeling werd opgevat als een maat voor validiteit. In tabel 5.3 wordt de totale fit per beoordelingsmethode voor elke groep beoordelaars weergegeven.

Tabel 5.3: Discriminant-analyse per beoordelingsmethode voor de drie groepen beoordelaars (uitgedrukt in het percentage juiste classificaties).

Beoordelaars vrije oordeel korte antw. sleutel ingedikte crit. uitgebreide crit.

$\begin{array}{lllll}\text { huisartsen } & 74.5 & 77.6 & 70.4 & 80.6 \\ \text { geneeskunde stud. } & 71.4 & 73.5 & 72.5 & 73.5 \\ \text { economie stud. } & 64.3 & 74.5 & 67.4 & 73.5\end{array}$

Bij het vrije oordeel was de trend waarneembaar dat de totale fit groter werd naarmate de medische expertise van de beoordelaars toenam. De korte antwoordsleutel leidde bij alle drie de groepen beoordelaars tot een betere fit dan het vrije oordeel. De grootste toename was waarneembaar bij de economie studenten. De totale fit was bij de economie studenten voor de korte antwoordsleutel zelfs iets hoger dan bij de geneeskunde studenten en gelijk aan de fit die door de huisartsen werd bereikt met het vrije oordeel. Bij de ingedikte criterialijst was bij alle drie de groepen beoordelaars een lichte mate van terugval in fit waameembaar. Voorts bleken bij deze beoordelingsmethode de beste resultaten te worden verkregen door de geneeskunde studenten. Van alle vier de beoordelingsmethoden leverde de uitgebreide criterialijst de beste fit op. Bij de economie studenten leidde de korte antwoordsleutel ook tot een groot aantal juiste classificaties.

Op basis van deze gegevens werd voorlopig geconcludeerd, dat de gestructureerde beoordelingsmethoden tot een grotere fit leidden dan het vrije oordeel, ongeacht de medische expertise van de beoordelaars. Opgemerkt dient te worden, dat het om relatief kleine verschillen ging, hetgeen kon zijn veroorzaakt door de grote spreiding van de scores binnen de jaargroepen.

Naast de gemiddelde scores en de discriminant-analyse werd op basis van de gemiddelde scores de correlatie tussen de verschillende beoordelingsmethoden bepaald. De geobserveerde correlaties en de ware correlaties zijn weergegeven in tabel 5.4. De correctie voor attenuatie, om te komen tot een schatting van de ware correlatie, is uitgevoerd met de interbeoordelaarsbetrouwbaarheid. De hoogte van de interbeoordelaarsbetrouwbaarheid wordt weergegeven in tabel 5.8 . 
Tabel 5.4: Geobserveerde en geattenueerde correlaties tussen de verschillende beoordelingsmethoden (respectievelijk in de linker benedenhoek en de rechter bovenhoek) voor elke groep beoordelaars $(n=16)$.

huisartsen als beoordelaars

Beoordelingsmethode vrije oordeel korte antw. sleutel ingedikte crit. uitgebreide crit.

vrije oordeel

korte antw. sleutel

ingedikte crit.

uitgebreide crit.

\subsection{3}

0.51

0.47
0.73

0.68

0.61

0.90

0.83

0.81

0.80

0.75

geneeskunde studenten als beoordelaars

Beoordelingsmethode vrije oordeel korte antw. sleutel ingedikte crit. uitgebreide crit.

vrije oordeel

kore antw. sleutel

ingedikte crit.

uitgebreide crit.

$\begin{array}{ll} & 0.79 \\ 0.57 & \\ 0.60 & 0.87 \\ 0.59 & 0.86\end{array}$

0.86
0.76

1.00

0.87
0.82

1.00

1.00

economie studenten als beoordelaars

Beoordelingsmethode vrije oordeel korte antw. sleutel ingedikte crit. uitgebreide crit.

vrije oordeel

korte antw. sleutel

ingedikte crit.

uitgebreide crit.

0.33
0.51
0.48

0.33

0.48
0.42

0.66

0.63
0.67

0.86

0.57

0.74

0.98

Uit tabel 5.4 blijkt dat bij de huisartsen de geobserveerde correlatie tussen het vrije oordeel en de drie gestructureerde beoordelingsmethoden varieerde van 0.47 tot en met 0.53. Bij deze groep werden tussen de drie gestructureerde beoordelingsmethoden correlaties gevonden van 0.75 tot en met 0.80 , hetgeen beduidend hoger was dan de correlatie met het vrije oordeel.

Bij de geneeskunde studenten varieerde de geobserveerde correlatie tussen het vrije oordeel en de drie gestructureerde beoordelingsmethoden van 0.57 tot en met 0.60 . De correlatie tussen de korte antwoordsleutel, de ingedikte en de uitgebreide criterialijst had bij deze groep een waarde van 0.86 of 0.87 .

Bij de economie studenten schommelde de geobserveerde correlatie tussen het vrije oordeel en de gestructureerde beoordelingsmethoden tussen 0.33 en 0.51 . Deze correlaties waren beduidend lager vergeleken met de correlatie tussen de gestructureerde beoor- 
delingsmethoden. Tussen de ingedikte en de uitgebreide criterialijst werd bij de economie studenten zelfs een correlatie van 0.80 gevonden. Verder viel op dat de geobserveerde correlatie tussen het vrije oordeel en de korte antwoordsleutel bij de economie studenten beduidend lager was dan bij de huisartsen en de geneeskunde studenten.

Hieruit zou kunnen worden afgeleid, dat vrije(re) beoordelingsmethoden tot verschillende, andersoortige scores leidden als gevolg van het feit dat iets anders werd beoordeeld dan met de gestructureerde beoordelingsmethoden. Een andere verklaring zou kunnen zijn, dat de lage correlaties werden veroorzaakt door een lagere interbeoordelaarsbetrouwbaarheid bij de vrije(ere) beoordelingsmethoden. Om deze tweede mogelijkheid te onderzoeken werd op de geobserveerde correlaties de correctie voor attenuatie toegepast, gebruikmakend van de interbeoordelaarsbetrouwbaarheid.

Uit tabel 5.4 blijkt dat bij alle drie de groepen beoordelaars de ware correlaties eenzelfde beeld vertoonden als de geobserveerde correlaties; de correlaties tussen het vrije oordeel en de gestructureerde beoordelingsmethoden waren lager dan de correlaties tussen de gestructureerde beoordelingsmethoden. Bij de huisartsen varieerde de ware correlatie tussen de 0.61 en de 0.90 . Bij de geneeskunde studenten varieerde de ware correlatie tussen het vrije oordeel en de gestructureerde beoordelingsmethoden tussen 0.76 en 0.82 . Tussen de drie gestructureerde beoordelingsmethoden werden zelfs perfecte ware correlaties gevonden. De ware correlaties tussen het vrije oordeel en de gestructureerde beoordelingsmethoden varieerden bij de economie studenten tussen 0.42 en 0.67 . De ware correlatie tussen de gestructureerde beoordelingsmethoden varieerde van 0.74 tot en met 0.98 tussen de ingedikte en de uitgebreide criterialijst.

Kortom, ook bij de ware correlaties werden duidelijke verschillen gevonden tussen het vrije oordeel en de gestructureerde beoordelingsmethoden. Het was de vraag in hoeverre meer differentiële effecten zouden worden gevonden tussen de verschillende beoordelingsmethoden, zodat uitsluitsel kon worden verkregen omtrent hetgeen daadwerkelijk met behulp van de verschillende beoordelingsmethoden werd gemeten. Hiertoe werd onder andere de correlatie berekend tussen de behaalde score op de casustoets en de behaalde score op de voortgangstoets van december 1989. De resultaten zijn weergegeven in tabel 5.5 .

In tabel 5.5 is te zien, dat bij elke beoordelingsmethode de correlatie tussen de behaalde scores op de casustoets en de voortgangstoets afnam met het aantal jaren gevolgd onderwijs, ongeacht de expertise van de beoordelaars. De correlatie was het hoogst bij het vrije oordeel voor de eerstejaars studenten. Bij deze jaargroep nam de correlatie af naarmate de beoordelingsmethode meer was gestructureerd. In vergelijking met de geneeskunde en economie studenten werd voor jaargroep 4 hogere correlaties gevonden bij de huisartsen. Bij de zesdejaars studenten werd een negatieve correlatie gevonden, in het geval dat ze door de huisartsen met de ingedikte criterialijst werden beoordeeld. De correlaties voor deze jaargroep waren bij alle beoordelingsmethoden beduidend lager dan bij de eerste- en vierdejaars studenten en varieerden van 0.02 tot 0.09 voor de verschillende groepen beoordelaars. Ondanks enkele kleine verschillen tussen de drie groepen beoordelaars werden in de gevonden correlaties geen duidelijke discrepanties tussen de beoordelingsmethoden gevonden.

De geobserveerde correlaties werden gecorrigeerd voor de verschillen tussen de beoordelaars. Ook na de correctie voor attenuatie was de trend waameembaar, dat de correlatie afnam naarmate de studenten meer medisch onderwijs hadden gevolgd, ongeacht de expertise van de beoordelaars en de gebruikte beoordelingsmethode. In het algemeen was 
het beeld gelijk aan de geobserveerde correlaties. Concluderend kan worden gesteld dat wat betreft de correlaties tussen de resultaten op de casustoets en de scores op de voortgangstoets geen eenduidige verschillen tussen de beoordelingsmethoden waarneembaar waren.

Tabel 5.5: Geobserveerde en geattenueerde correlaties tussen de goed-minus-fout-score op de voongangstoets van december 1989 en de behaalde score op de casustoets per jaargroep en per beoordelingsmethode voor elke groep beoordelaars.

\begin{tabular}{|c|c|c|c|c|c|c|c|}
\hline \multirow[b]{2}{*}{$\begin{array}{l}\text { beoordelings- } \\
\text { methode }\end{array}$} & \multirow[b]{2}{*}{$\begin{array}{l}\text { jaar- } \\
\text { groep }\end{array}$} & \multicolumn{6}{|c|}{ beoordelaars } \\
\hline & & \multicolumn{2}{|c|}{ huisartsen } & \multicolumn{2}{|c|}{$\begin{array}{l}\text { geneeskunde } \\
\text { studenten }\end{array}$} & \multicolumn{2}{|c|}{$\begin{array}{l}\text { economie } \\
\text { studenten }\end{array}$} \\
\hline & & $\begin{array}{c}\text { geobs. } \\
\text { corr. }\end{array}$ & $\begin{array}{l}\text { ware } \\
\text { corr. }\end{array}$ & $\begin{array}{c}\text { geobs. } \\
\text { corr. }\end{array}$ & $\begin{array}{l}\text { ware } \\
\text { corr. }\end{array}$ & $\begin{array}{c}\text { geobs. } \\
\text { corr. }\end{array}$ & $\begin{array}{l}\text { ware } \\
\text { corr. }\end{array}$ \\
\hline vrije oordeel & $\begin{array}{l}\mathrm{I}^{\circ} \\
4^{*} \\
6^{\circ *}\end{array}$ & $\begin{array}{l}0.67 \\
0.35 \\
0.06\end{array}$ & $\begin{array}{l}1.00 \\
0.53 \\
0.09\end{array}$ & $\begin{array}{l}0.63 \\
0.24 \\
0.09\end{array}$ & $\begin{array}{l}0.99 \\
0.35 \\
0.13\end{array}$ & $\begin{array}{l}0.65 \\
0.27 \\
0.00\end{array}$ & $\begin{array}{l}0.93 \\
0.36 \\
0.00\end{array}$ \\
\hline $\begin{array}{l}\text { korte antw. } \\
\text { sleutel }\end{array}$ & $\begin{array}{l}1 \\
4 \\
6\end{array}$ & $\begin{array}{l}0.45 \\
0.46 \\
0.02\end{array}$ & $\begin{array}{l}0.62 \\
0.58 \\
0.03\end{array}$ & $\begin{array}{l}0.41 \\
0.33 \\
0.08\end{array}$ & $\begin{array}{l}0.59 \\
0.44 \\
0.11\end{array}$ & $\begin{array}{l}0.43 \\
0.30 \\
0.10\end{array}$ & $\begin{array}{l}0.62 \\
0.40 \\
0.13\end{array}$ \\
\hline $\begin{array}{l}\text { ingedikte } \\
\text { criterialijst }\end{array}$ & $\begin{array}{l}1 \\
4 \\
6\end{array}$ & $\begin{array}{r}0.44 \\
0.41 \\
-0.16\end{array}$ & $\begin{array}{r}0.59 \\
0.51 \\
-0.20\end{array}$ & $\begin{array}{l}0.43 \\
0.32 \\
0.04\end{array}$ & $\begin{array}{l}0.57 \\
0.39 \\
0.05\end{array}$ & $\begin{array}{l}0.43 \\
0.28 \\
0.06\end{array}$ & $\begin{array}{l}0.63 \\
0.38 \\
0.08\end{array}$ \\
\hline $\begin{array}{l}\text { uitgebreide } \\
\text { criterialijst }\end{array}$ & $\begin{array}{l}1 \\
4 \\
6\end{array}$ & $\begin{array}{l}0.38 \\
0.40 \\
0.08\end{array}$ & $\begin{array}{l}0.50 \\
0.49 \\
0.10\end{array}$ & $\begin{array}{l}0.38 \\
0.28 \\
0.09\end{array}$ & $\begin{array}{l}0.55 \\
0.38 \\
0.12\end{array}$ & $\begin{array}{l}0.40 \\
0.21 \\
0.07\end{array}$ & $\begin{array}{l}0.5 \\
0.26 \\
0.09\end{array}$ \\
\hline
\end{tabular}

* $\mathrm{n}=18$

** $n=40$

Voorts werd de correlatie tussen de drie groepen beoordelaars berekend. De resultaten zijn weergegeven in tabel 5.6. In tabel 5.6 zijn de geobserveerde correlaties linksonder in de subtabellen weergegeven, terwijl de ware correlaties cursief in de rechterbovenhoek zijn weergegeven.

In de tabel is te zien dat de geobserveerde correlatie tussen de verschillende groepen beoordelaars varieerde van 0.22 tot 0.84 . Bij alle drie de jaargroepen werden de laagste correlaties tussen de groepen beoordelaars gevonden bij het vrije oordeel, met uitzondering van de correlatie tussen de huisartsen en de geneeskunde studenten bij de eerstejaars studenten. Opvallend is dat bij de eerstejaars studenten de correlatie daalde bij de uitgebreide criterialijst. Bij de vierdejaars studenten was de correlatie tussen de huisartsen en de geneeskunde studenten nagenoeg gelijk bij de drie gestructureerde beoordelingsmethoden. Met de ingedikte en de uitgebreide criterialijst werden bij deze jaargroep correlatiesvan 0.77 tot en met 0.84 gevonden tussen de drie groepen beoordelaars. 
Tabel 5.6: Geobserveerde en ware correlaties tussen de drie groepen beoordelaars (in de linker beneden- en de rechter bovenhoek) per jaargroep en per beoordelingsmethode $(n=16)$.

jaargroep 1

\begin{tabular}{|c|c|c|c|c|c|c|c|c|c|c|c|c|}
\hline \multirow{5}{*}{$\begin{array}{l}\text { ha } \\
\text { gen } \\
\text { ec }\end{array}$} & \multicolumn{3}{|c|}{ vrije oordeel } & \multicolumn{3}{|c|}{$\begin{array}{c}\text { korte } \\
\text { antwoord } \\
\text { sleutel }\end{array}$} & \multicolumn{3}{|c|}{$\begin{array}{l}\text { ingedikte } \\
\text { criterialijst }\end{array}$} & \multicolumn{3}{|c|}{$\begin{array}{l}\text { uitgebreide } \\
\text { criterialijst }\end{array}$} \\
\hline & ha & gen & ec & ha & gen & $\mathrm{ec}$ & ha & gen & ec & ha & gen & $\mathrm{ec}$ \\
\hline & & 0.92 & 0.56 & & 0.91 & 0.77 & & 0.79 & 0.93 & & 0.59 & 0.53 \\
\hline & 0.59 & & 0.86 & 0.75 & & 0.90 & 0.73 & & 0.88 & 0.50 & & 0.88 \\
\hline & 0.39 & 0.62 & & 0.64 & 0.71 & & 0.76 & 0.73 & & 0.52 & 0.73 & \\
\hline & \multicolumn{3}{|c|}{ vrije oordeel } & \multicolumn{3}{|c|}{$\begin{array}{c}\text { kore } \\
\text { antwoord } \\
\text { sleutel }\end{array}$} & \multicolumn{3}{|c|}{$\begin{array}{l}\text { ingedikte } \\
\text { criterialijst }\end{array}$} & \multicolumn{3}{|c|}{$\begin{array}{l}\text { uitgebreide } \\
\text { uriterialijst }\end{array}$} \\
\hline & ha & gen & ec & ha & gen & ec & ha & gen & ec & ha & gen & ec \\
\hline ha & & 0.97 & 0.57 & & 0.98 & 0.88 & & 0.91 & 0.94 & & 0.95 & 0.84 \\
\hline gen & 0.62 & & 0.69 & 0.81 & & 0.78 & 0.84 & & 0.96 & 0.81 & & 0.96 \\
\hline ec & 0.37 & 0.50 & & 0.67 & 0.62 & & 0.77 & 0.80 & & 0.77 & 0.80 & \\
\hline & \multicolumn{12}{|c|}{ jaargroep 6} \\
\hline
\end{tabular}

\begin{tabular}{|c|c|c|c|c|c|c|c|c|c|c|c|c|}
\hline & & je oor & deel & & $\begin{array}{l}\text { korte } \\
\text { intwoo } \\
\text { sleute }\end{array}$ & & & $\begin{array}{l}\text { ngedik } \\
\text { iterial }\end{array}$ & $\begin{array}{l}\text { te } \\
\text { ijst }\end{array}$ & & $\begin{array}{l}\text { tgebre } \\
\text {-iterial }\end{array}$ & $\begin{array}{l}\text { eide } \\
\text { lijst }\end{array}$ \\
\hline & ha & gen & $e c$ & ha & gen & $e c$ & $h a$ & gen & $e c$ & ha & gen & $e c$ \\
\hline ha & & 0.77 & 0.32 & & 0.85 & 0.86 & & 0.81 & 0.66 & & 0.89 & 0.80 \\
\hline gen & 0.49 & & 0.48 & 0.70 & & 0.71 & 0.74 & & 0.84 & 0.76 & & 0.95 \\
\hline ec & 0.22 & 0.35 & & 0.67 & 0.56 & & 0.54 & 0.70 & & 0.74 & 0.79 & \\
\hline
\end{tabular}


Met uitzondering van de lagere correlatie tussen de huisartsen en de economie studenten bij de ingedikte criterialijst, nam bij de zesdejaars studenten de correlatie tussen de groepen beoordelaars toe naarmate de structuur van de beoordelingsmethode toenam. De geobserveerde correlatie varieerde van 0.54 tot 0.79 . Het lijkt er dus op, dat het aanbrengen van structuur er toe bijdraagt dat door de verschillende groepen beoordelaars eenzelfde beoordeling wordt gegeven.

Uit tabel 5.6 blijkt dat bij jaargroep 1 de ware correlatie tussen de groepen beoordelaars kleiner werd naarmate de beoordelingsmethode meer was gestructureerd. Dit bleek met name het gevolg te zijn van de stijgende interbeoordelaarsbetrouwbaarheid bij de gestructureerde beoordelingsmethoden. Bij de vierde- en zesdejaars studenten nam met name de correlatie tussen de economie studenten en de andere twee groepen beoordelaars toe bij de gestructureerde beoordelingsmethoden.

Uit het correlationeel onderzoek bleek, dat bij het vrije oordeel de overeenstemming tussen de geneeskunde studenten en de huisartsen beduidend groter was in vergelijking met de economie studenten. Bij het beoordelen met deze beoordelingsmethode leek een minimale medische expertise vereist. Indien een minimale structurering was aangebracht nam de overeenstemming tussen de groepen beoordelaars toe en werden, wat betreft de mate van overeenstemming, weinig tot geen verschillen tussen de groepen beoordelaars gevonden.

\subsubsection{Generaliseerbaarheidsanalyses}

\subsubsection{G-studie}

Om de invloed van verschillende factoren op de totale variantie te bestuderen, werd een G-studie uitgevoerd. De resultaten van deze G-studie worden in tabel 5.7 weergegeven. Bij de variantie-componenten werden relatief grote standard errors gevonden. Het was dan ook noodzakelijk om bij de interpretatie van de gevonden resultaten hiermee rekening te houden en bij het trekken van conclusies grote voorzichtigheid te betrachten.

De grootte van de variantiecomponent behorende bij het hoofdeffect personen (p) vormt een indicatie voor de spreiding in de behaalde scores door de studenten. Deze variantiecomponent was het grootst bij het vrije oordeel, ongeacht de medische expertise van de beoordelaars. Tevens nam de grootte van deze component af bij de meer gestructureerde beoordelingsmethoden. Het leek er dus op, dat het aanbrengen van structuur de variatie in de scores tussen personen binnen jaargroepen reduceerde.

Het itemeffect (i) geeft aan in welke mate er verschillen bestaan tussen de gemiddeld behaalde scores op de verschillende casus, hetgeen een indicatie vormt voor de variatie in moeilijkheidsgraad van de verschillende casus. In tegenstelling tot bij het persoonseffect, was de grootte van dit effect sterker voor de gestructureerde beoordelingsmethoden, indien werd beoordeeld door inhoudsdeskundige beoordelaars. Bij de economie studenten leidde de uitgebreide criterialijst tot de kleinste verschillen tussen casus. Bij de huisartsen en de economie studenten was de spreiding in de casusscores het grootst bij de korte antwoordsleutel, terwijl bij de geneeskunde studenten de ingedikte criterialijst tot de grootste i-component leidde. Het bleek dus, dat de casus in moeilijkheid van elkaar verschilden. Met betrekking tot de relatie tussen de beoordelingsmethoden en de inhoudsdeskundigheid van de beoordelaars op de grootte van de casusvariantie was geen 
duidelijke trend waameembaar.

De mate waarin beoordelaars systematisch verschillen wat betreft de hoogte van hun beoordelingen wordt gerepresenteerd in het hoofdeffect beoordelaars. Bij de inhoudsdeskundige beoordelaars leidde het vrije oordeel tot de grootste verschillen tussen beoordelaars, terwijl bij de economie studenten deze verschillen het sterkst optraden bij zowel het vrije oordeel als de korte antwoordsleutel. Bij de huisartsen werd een trend geconstateerd, dat de systematische verschillen tussen de beoordelaars geleidelijk afnamen door debeoordelingsmethoden meer te structureren. De systematische verschillen tussen de

Tabel 5.7: Geschatte variantiecomponenten en standard errors per beoordelingsmethode voor de verschillende hoofd- en interactie-effecten, voor elke groep beoordelaars.

\begin{tabular}{|c|c|c|c|c|c|c|c|c|}
\hline \multirow[t]{3}{*}{$\begin{array}{l}\text { Var. } \\
\text { bron }\end{array}$} & \multicolumn{8}{|c|}{ Beoordelingsmethode } \\
\hline & \multicolumn{2}{|c|}{ vrije oordeel } & \multicolumn{2}{|c|}{$\begin{array}{c}\text { korte antwoord } \\
\text { sleutel }\end{array}$} & \multicolumn{2}{|c|}{$\begin{array}{c}\text { ingedikte } \\
\text { criterialijst }\end{array}$} & \multicolumn{2}{|c|}{$\begin{array}{l}\text { uitgebreide } \\
\text { criterialijst }\end{array}$} \\
\hline & $\begin{array}{l}\text { Var. } \\
\text { comp. }\end{array}$ & $\begin{array}{l}\text { St. } \\
\text { error }\end{array}$ & $\begin{array}{l}\text { Var. } \\
\text { comp. }\end{array}$ & $\begin{array}{c}\text { St. } \\
\text { error }\end{array}$ & $\begin{array}{l}\text { Var. } \\
\text { comp. }\end{array}$ & $\begin{array}{l}\text { St. } \\
\text { error }\end{array}$ & $\begin{array}{l}\text { Var. } \\
\text { comp. }\end{array}$ & $\begin{array}{l}\text { St. } \\
\text { error }\end{array}$ \\
\hline & \multicolumn{8}{|c|}{ huisartsen als beoordelaars } \\
\hline $\mathrm{p}$ & 43.39 & 16.76 & 28.46 & 14.62 & 16.71 & 12.40 & 18.35 & 11.51 \\
\hline $\mathrm{i}$ & 33.09 & 48.96 & 172.79 & 88.40 & 93.25 & 48.30 & 52.87 & 31.32 \\
\hline $\mathrm{j}$ & 48.16 & 51.04 & 10.95 & 10.78 & 6.56 & 6.15 & 3.01 & 4.30 \\
\hline pi & 72.50 & 16.78 & 242.28 & 23.77 & 237.02 & 23.47 & 213.69 & 19.45 \\
\hline pj & 122.30 & 10.44 & 109.65 & 9.35 & 89.55 & 7.37 & 63.09 & 5.38 \\
\hline $\mathrm{ij}$ & 102.86 & 50.80 & 15.26 & 8.00 & 4.64 & 3.04 & 14.84 & 7.33 \\
\hline \multirow[t]{2}{*}{ pij, err. } & 196.22 & 16.74 & 68.74 & 5.86 & 71.67 & 6.11 & 27.95 & 2.38 \\
\hline & \multicolumn{8}{|c|}{ geneeskunde studenten als beoordelaars } \\
\hline $\mathrm{p}$ & 38.50 & 13.93 & 29.21 & 15.19 & 25.90 & 13.64 & 20.53 & 11.68 \\
\hline $\mathrm{i}$ & 25.89 & 27.63 & 42.56 & 26.59 & 98.49 & 52.15 & 36.60 & 21.20 \\
\hline $\mathrm{j}$ & 119.85 & 103.25 & 25.03 & 22.21 & 1.57 & 2.67 & 55.80 & 46.30 \\
\hline pi & 70.16 & 13.64 & 224.06 & 22.93 & 240.14 & 22.30 & 206.17 & 19.46 \\
\hline pj & 9.46 & 6.28 & 8.86 & 4.34 & 3.64 & 1.99 & 5.03 & 2.32 \\
\hline $\mathrm{ij}$ & 46.88 & 23.81 & 13.34 & 7.27 & 10.92 & 5.63 & 5.14 & 2.92 \\
\hline \multirow[t]{2}{*}{ pij, err. } & 144.87 & 12.35 & 83.12 & 7.08 & 41.11 & 3.51 & 42.09 & 3.59 \\
\hline & \multicolumn{8}{|c|}{ economie studenten als beoordelaars } \\
\hline $\mathrm{p}$ & 48.20 & 16.65 & 23.91 & 13.64 & 17.59 & 12.09 & 19.41 & 11.30 \\
\hline $\mathrm{i}$ & 92.62 & 53.47 & 161.84 & 81.12 & 65.35 & 41.52 & 50.90 & 27.88 \\
\hline j & 46.01 & 41.48 & 55.30 & 46.49 & 18.61 & 18.88 & 12.91 & 11.31 \\
\hline $\mathrm{pi}$ & 81.65 & 13.25 & 187.08 & 21.15 & 188.43 & 20.25 & 192.70 & 19.31 \\
\hline $\mathrm{pj}$ & 14.84 & 6.78 & 10.41 & 5.45 & 11.23 & 5.04 & 4.33 & 2.78 \\
\hline ij & 31.77 & 16.42 & 8.20 & 5.16 & 30.67 & 15.51 & 5.05 & 3.13 \\
\hline pij, err. & 122.30 & 10.44 & 109.65 & 9.35 & 89.55 & 7.37 & 63.09 & 5.38 \\
\hline
\end{tabular}


geneeskunde studenten waren bij de uitgebreide criterialijst aanzienlijk groter vergelekenmet de korte antwoordsleutel en de ingedikte criterialijst. Bij de economie studenten werden deze beoordelaarsverschillen kleiner bij de ingedikte en de uitgebreide criterialijst. Ondanks de wat hogere component voor de geneeskunde studenten bij de uitgebreide criterialijst leek te kunnen worden geconcludeerd, dat het bieden van meer structuur de systematische verschillen tussen de beoordelaars deed afnemen.

Met betrekking tot het meten van vaardigheid in medisch probleemoplossen is bekend, dat de behaalde score op een casus weinig tot geen voorspellende waarde heeft ten aanzien van de te verwachten score op een andere casus. Dit fenomeen van inhoudsspecificiteit wordt in het pi-interactie-effect gerepresenteerd. Dit effect geeft weer in welke mate de studenten verschillend werden geordend op de verschillende casus.

Zoals kon worden verwacht, werd voor dit interactie-effect een relatief grote variantiecomponent gevonden, ongeacht de gehanteerde beoordelingsmethode en de medische expertise van de beoordelaars. Wel was dit interactie-effect beduidend hoger bij de gestructureerde beoordelingsmethoden dan bij het vrije oordeel. Tussen de gestructureerde beoordelingsmethoden werden relatief weinig verschillen in de grootte van de component gevonden. Het pi-effect was bij de gestructureerde beoordelingsmethoden groter voor de huisartsen en de geneeskunde studenten dan voor de economie studenten. Bij het vrije oordeel was dit effect daarentegen iets groter bij de economie studenten.

In hoeverre de beoordelaars een andere rangordening tussen personen aanbrengen, komt tot uitdrukking in het $\mathrm{pj}$-interactie-effect. Bij de huisartsen was dit effect het grootst bij het vrije oordeel, terwijl bij de gestructureerde methoden de korte antwoordsleutel tot de kleinste verschillen leidde. Dit interactie-effect was bij de geneeskunde studenten het kleinst bij de ingedikte criterialijsten en het grootst bij het vrije oordeel. Bij de economie studenten nam dit effect af naarmate de beoordelingsmethode meer was gestructureerd. Wat betreft de absolute grootte van deze component bleek, dat de gevonden waarde voor de economie studenten bij de uitgebreide criterialijst vrijwel gelijk te zijn met de laagste waarde bij de inhoudsdeskundige beoordelaars. Bij alle drie de groepen beoordelaars waren de gevonden componenten bij dit effect verreweg het kleinst vergeleken met alle andere variantiecomponenten. Samenvattend kon worden gesteld, dat wat betreft de rangordening van de studenten het bieden van structuur de overeenstemming tussen beoordelaars deed toenemen en dat ook leken met een sterk gestructureerde beoordelingsmethode tot een redelijke overeenstemming konden komen.

De mate waarin beoordelaars verschillend beoordeelden over de casus komt tot uitdrukking in het ij-interactie-effect. Bij alle drie de groepen beoordelaars was dit effect beduidend groter bij het vrije oordeel dan bij de gestructureerde beoordelingsmethoden, alhoewel bij de economie studenten ook bij de ingedikte criterialijst een vrijwel even grote component werd gevonden. De ingedikte criterialijst leidde bij de huisartsen tot de kleinste component, terwijl bij de geneeskunde en de economie studenten de uitgebreide criterialijst tot de minste verschillen leidde. Bij de geneeskunde studenten was een trend waameembaar, dat de variantiecomponent voor dit interactie-effect afnam bij een toenemende structurering van de beoordelingsmethode. Kortom, het bieden van structuur leek ook de grootte van het ij-interactie-effect positief te beïnvloeden, ongeacht de medische expertise van de beoordelaars.

In hoeverre personen anders worden gerangordend door beoordelaars en casus is niet te ontrafelen uit de overige foutenvariantie. Deze pij- en errorvariantie was bij elke groep beoordelaars het grootst bij het vrije oordeel, zij het dat de grootte afnam naarmate de beoordelaars minder inhoudsdeskundig waren. Bij de huisartsen werd een kleine pij- 
variantiecomponent gevonden bij de uitgebreide criterialijst, terwijl tussen de korte antwoordsleutel en de ingedikte criterialijst nauwelijks een verschil waarneembaar was. Deze component was bij de geneeskunde studenten het kleinst voor zowel de ingedikte als de uitgebreide criterialijst. De uitgebreide criterialijst leidde bij de economie studenten tot de minste variantie. Met betrekking tot de errorvariantie viel tevens op dat deze toenam naarmate de beoordelaars minder inhoudsdeskundig waren.

Bij het vergelijken van het vrije oordeel met de gestructureerde beoordelingsmethoden viel op, dat bij het vrije oordeel zowel de grootste ware als algemene error variantie werd gevonden. De grootte van het pi-effect was daarentegen beduidend kleiner dan bij de gestructureerde beoordelingsmethoden. Het leek er op dat bij de meer holistische beoordelingsmethoden de algemene error variantie tronam ten gunste van de pi-component, terwijl bij de gestructureerde beoordelingsmethoden de algemene error variantie afnam ten koste van het pi-effect.

\subsubsection{D-studies}

\subsection{Interbeoordelaarsbetrouwbaarheid}

De eerste D-studie die werd uitgevoerd, had tot doel de interbeoordelaarsbetrouwbaarheid te bepalen. De berekening vond plaats aan de hand van de formule zoals die is beschreven in paragraaf 4.2. Voor elke groep beoordelaars wordt de overeenstemming tussen de beoordelaars per beoordelingsmethode weergegeven in tabel 5.8.

Tabel 5.8: Interbeoordelaarsbetrouwbaarheid per beoordelingsmethode voor elke groep beoordelaars.

\begin{tabular}{lcccc} 
Beoordelaars & vrije oordeel & korte antw. sleutel & ingedikte crit. & uitgebreide crit. \\
\hline huisartsen & 0.61 & 0.87 & 0.91 & 0.94 \\
geneeskunde stud. & 0.67 & 0.78 & 0.93 & 0.77 \\
economie stud. & 0.78 & 0.80 & 0.74 & 0.90 \\
\end{tabular}

In tabel 5.8 is te zien dat in het algemeen de interbeoordelaarsbetrouwbaarheid toenam naarmate de beoordelingsmethode meer was gestructureerd. Een uitzondering op deze regel vormde de terugval bij de uitgebreide criterialijst bij de geneeskunde studenten en de afname bij de ingedikte criterialijst bij de economie studenten. Opvallend was het grote verschil in de betrouwbaarheid tussen het vrije oordeel en de korte antwoordsleutel bij de huisartsen; een minimale structurering van het beoordelingsproces bleek hier grote invloed te hebben op de overeenstemming tussen beoordelaars. Daarnaast was het opmerkelijk, dat bij de economie studenten een betrouwbaarheid van 0.78 werd gevonden bij het vrije oordeel, hetgeen zelfs hoger was dan bij de ingedikte criterialijst. 


\subsection{Totale toetsbetrouwbaarheid}

Om de consequenties van de verhoudingen tussen de variantiebronnen op de totale toetsbetrouwbaarheid in kaart te brengen werd een viertal D-studies uitgevoerd. De eerste D-studie werd uitgevoerd met een volledig gekruist $\mathrm{p} \times \mathrm{i} \times \mathrm{j}$-design, uitgaande van een norm georiënteerd perspectief. In deze opzet werden alle casus voor alle studenten door dezelfde beoordelaars nagekeken. De resultaten zijn weergegeven in tabel 5.9.

Tabel 5.9: Generaliseerbaarheidscoëfficiënten als een functie van het aantal casus en beoordelaars bij een volledig gekruist $\mathrm{p}$ x i x j-design, voor de drie groepen beoordelaars.

\begin{tabular}{|c|c|c|c|c|c|c|c|c|}
\hline \multirow{3}{*}{$\begin{array}{c}\text { aantal } \\
\text { casus }\end{array}$} & \multicolumn{8}{|c|}{ Beoordelingsmethode } \\
\hline & \multicolumn{2}{|c|}{ vrije oordeel } & \multicolumn{2}{|c|}{$\begin{array}{c}\text { korte } \\
\text { antwoord } \\
\text { sleutel }\end{array}$} & \multicolumn{2}{|c|}{$\begin{array}{l}\text { ingedikte } \\
\text { criterialijst }\end{array}$} & \multicolumn{2}{|c|}{$\begin{array}{l}\text { uitgebreide } \\
\text { criterialijst }\end{array}$} \\
\hline & $\begin{array}{l}\text { éen } \\
\text { beoor }\end{array}$ & $\begin{array}{l}\text { twee } \\
\text { laars }\end{array}$ & $\begin{array}{l}\text { eén } \\
\text { beoor }\end{array}$ & $\begin{array}{l}\text { twee } \\
\text { elaars }\end{array}$ & $\begin{array}{l}\text { eén } \\
\text { beoo }\end{array}$ & $\begin{array}{l}\text { twee } \\
\text { elaars }\end{array}$ & $\begin{array}{l}\text { eén } \\
\text { beoor }\end{array}$ & $\begin{array}{l}\text { twee } \\
\text { elaars }\end{array}$ \\
\hline & \multicolumn{8}{|c|}{ huisartsen als beoordelaars } \\
\hline 4 & 0.34 & 0.46 & 0.26 & 0.29 & 0.17 & 0.19 & 0.21 & 0.23 \\
\hline 8 & 0.47 & 0.60 & 0.40 & 0.44 & 0.27 & 0.31 & 0.33 & 0.36 \\
\hline 12 & 0.53 & 0.66 & 0.50 & 0.54 & 0.34 & 0.39 & 0.40 & 0.45 \\
\hline \multirow[t]{2}{*}{40} & 0.66 & 0.78 & 0.73 & 0.77 & 0.54 & 0.63 & 0.57 & 0.66 \\
\hline & \multicolumn{8}{|c|}{ geneeskunde studenten als beoordelaars } \\
\hline 4 & 0.39 & 0.49 & 0.25 & 0.29 & 0.26 & 0.28 & 0.23 & 0.26 \\
\hline 8 & 0.51 & 0.63 & 0.38 & 0.44 & 0.40 & 0.43 & 0.36 & 0.40 \\
\hline 12 & 0.58 & 0.70 & 0.46 & 0.52 & 0.49 & 0.52 & 0.44 & 0.49 \\
\hline \multirow[t]{2}{*}{40} & 0.72 & 0.82 & 0.64 & 0.73 & 0.71 & 0.76 & 0.65 & 0.71 \\
\hline & \multicolumn{8}{|c|}{ economie studenten als beoordelaars } \\
\hline 4 & 0.42 & 0.53 & 0.22 & 0.27 & 0.18 & 0.22 & 0.22 & 0.25 \\
\hline 8 & 0.54 & 0.66 & 0.33 & 0.40 & 0.28 & 0.34 & 0.35 & 0.39 \\
\hline 12 & 0.60 & 0.71 & 0.40 & 0.49 & 0.34 & 0.41 & 0.43 & 0.48 \\
\hline 40 & 0.71 & 0.81 & 0.57 & 0.68 & 0.49 & 0.61 & 0.64 & 0.71 \\
\hline
\end{tabular}

* 4 casus is ongeveer $l$ uur toetstiju.

Bij alle drie de groepen beoordelaars werden de grootste generaliseerbaarheidscoëfficienten gevonden bij het vrije oordeel, hetgeen op basis van de variantiecomponenten kon worden verwacht. Door het feit dat de variantie voor het pi en pij effect in verhouding 
een veel groter aandeel innam dan het beoordelaarsfacet (pj) en het feit dat bij het vrije oordeel de grootste ware variantie werd gevonden, ontstond de paradoxale situatie, dat beoordelingen met het vrije oordeel ondanks de lagere interbeoordelaarsbetrouwbaarheid de meest betrouwbare informatie opleverde. Opmerkelijk was dat ook de economie studenten met het vrije oordeel tot de meest betrouwbare uitspraken kwamen. Dit was met name het gevolg van de grootte van de ware variantiecomponent (p) verkregen bij deze groep beoordelaars. Voorts bleek zelfs dat bij het vrije oordeel de coëfficiënten bij de economie studenten het hoogst waren en dat de hoogte afnam naarmate de beoordelaars meer deskundig waren.

Van de gestructureerde beoordelingsmethoden leverde bij de huisartsen de korte antwoordsleutel de beste betrouwbaarheid op. Dit was met name toe te schrijven aan de hogere ware variantie en de lagere component voor het beoordelaarseffect (pj), vergeleken met de ingedikte en de uitgebreide criterialijst. $\mathrm{Bij}$ de geneeskunde en de economie studenten waren wat de totale betrouwbaarheid betreft weinig verschillen tussen de gestructureerde beoordelingsmethoden waar te nemen.

In de G-studie was gebleken, dat de variantiebronnen waarin de beoordelaar een rol speelt beduidend groter waren bij het vrije oordeel dan bij de gestructureerde beoordelingsmethoden. Hierdoor had bij het vrije oordeel het toevoegen van een tweede beoordelaar een grotere invloed op de totale toetsbetrouwbaarheid dan bij de gestructureerde beoordelingsmethoden.

Ten slotte blijkt uit tabel 5.9 wederom, dat een groot aantal casus nodig was om een acceptabele betrouwbaarheid te bereiken. Zelfs bij een aantal van 40 laat de totale toetsbetrouwbaarheid in veel gevallen nog te wensen over.

In de tweede D-studie werd een $\mathrm{p} x \mathrm{j}$ :i-design gehanteerd. In een dergelijk design wordt elke casus door andere beoordelaars nagekeken. De beoordelaarsvariantie zal in deze situatie nog sneller uitmiddelen dan in het vorige design, waardoor hogere coëfficiënten zullen worden verkregen. De resultaten van deze D-studie, die eveneens werd uitgevoerd vanuit een norm georiënteerd perspectief, worden gepresenteerd in tabel 5.10.

Zoals kon worden verwacht, werden bij alle drie de groepen beoordelaars de grootste coëfficiënten verkregen bij het vrije oordeel. Uit de G-studie bleek namelijk dat bij deze beoordelingsmethode de invloed van beoordelaarseffecten groter was dan bij de gestructureerde beoordelingsmethoden. Hierdoor werden de verschillen in de grootte tussen de gevonden coëfficiënten voor het vrije oordeel en de gestructureerde beoordelingsmethoden versterkt. Verder gaven de resultaten van het geneste design eenzelfde beeld te zien als het hiervoor beschreven gekruiste design. Zo leverde van de gestructureerde beoordelingsmethoden bij de huisartsen de korte antwoordsleutel de hoogste betrouwbaarheid op. Wat betreft de totale betrouwbaarheid werden bij de geneeskunde studenten en de economie studenten wederom geen duidelijke verschillen tussen de gestructureerde beoordelingsmethoden gevonden.

Evenals bij het gekruiste design was de generaliseerbaarheidscoëfficiënt bij het vrije oordeel het grootst bij de economie studenten en het kleinst bij de huisartsen. Dit leek wederom met name te worden veroorzaakt door de grotere ware variantie en de geringe pi- en algemene error variantie. 
Tabel 5.10: Generaliseerbaarheidscoëfficiënten als een functie van het aantal casus en beoordelaars bij een genest $\mathrm{p}$ x j:i-design, voor de drie groepen beoordelaars.

\begin{tabular}{|c|c|c|c|c|c|c|c|c|}
\hline \multirow{3}{*}{$\begin{array}{l}\text { aantal } \\
\text { casus }\end{array}$} & \multicolumn{8}{|c|}{ Beoordelingsmethode } \\
\hline & \multicolumn{2}{|c|}{ vrije oordeel } & \multicolumn{2}{|c|}{$\begin{array}{c}\text { korte } \\
\text { antwoord } \\
\text { sleutel }\end{array}$} & \multicolumn{2}{|c|}{$\begin{array}{c}\text { ingedikte } \\
\text { criterialijst }\end{array}$} & \multicolumn{2}{|c|}{$\begin{array}{l}\text { uitgebreide } \\
\text { criterialijst }\end{array}$} \\
\hline & $\begin{array}{l}\text { ến } \\
\text { beoo }\end{array}$ & $\begin{array}{l}\text { twee } \\
\text { elaars }\end{array}$ & $\begin{array}{l}\text { énn } \\
\text { beoo }\end{array}$ & $\begin{array}{l}\text { twee } \\
\text { elaars }\end{array}$ & $\begin{array}{l}\text { eén } \\
\text { beoo }\end{array}$ & $\begin{array}{l}\text { twee } \\
\text { laars }\end{array}$ & $\begin{array}{l}\text { éen } \\
\text { beoo }\end{array}$ & $\begin{array}{l}\text { twee } \\
\text { elaars }\end{array}$ \\
\hline & \multicolumn{8}{|c|}{ huisartsen als beoordelaars } \\
\hline 4 & 0.38 & 0.49 & 0.27 & 0.29 & 0.18 & 0.19 & 0.23 & 0.34 \\
\hline 8 & 0.55 & 0.66 & 0.42 & 0.45 & 0.30 & 0.33 & 0.37 & 0.39 \\
\hline 12 & 0.65 & 0.74 & 0.52 & 0.55 & 0.39 & 0.42 & 0.47 & 0.49 \\
\hline \multirow[t]{2}{*}{40} & 0.86 & 0.91 & 0.78 & 0.80 & 0.68 & 0.71 & 0.75 & 0.76 \\
\hline & \multicolumn{8}{|c|}{ geneeskunde studenten als beoordelaars } \\
\hline 4 & 0.41 & 0.51 & 0.27 & 0.30 & 0.27 & 0.28 & 0.24 & 0.26 \\
\hline 8 & 0.58 & 0.68 & 0.43 & 0.46 & 0.42 & 0.44 & 0.39 & 0.42 \\
\hline 12 & 0.67 & 0.76 & 0.53 & 0.56 & 0.52 & 0.54 & 0.49 & 0.52 \\
\hline \multirow[t]{2}{*}{40} & 0.87 & 0.91 & 0.79 & 0.81 & 0.78 & 0.80 & 0.76 & 0.78 \\
\hline & \multicolumn{8}{|c|}{ economie studenten als beoordelaars } \\
\hline 4 & 0.47 & 0.56 & 0.24 & 0.28 & 0.20 & 0.23 & 0.23 & 0.26 \\
\hline 8 & 0.64 & 0.72 & 0.38 & 0.44 & 0.33 & 0.37 & 0.37 & 0.41 \\
\hline 12 & 0.73 & 0.79 & 0.48 & 0.54 & 0.42 & 0.47 & 0.47 & 0.51 \\
\hline 40 & 0.90 & 0.93 & 0.76 & 0.79 & 0.71 & 0.75 & 0.75 & 0.77 \\
\hline
\end{tabular}

* 4 casus is ongeveer 1 uur toetstijd.

Beide D-studies werden eveneens uitgevoerd onder een domein georiënteerd perspectief. In een domein georiënteerd perspectief worden, zoals in paragraaf 5.2 is beschreven, alle overige variantiecomponenten die zowel de rangorde als het absolute niveau kunnen beïnvloeden, opgenomen in de foutenvariantie. Ondanks het feit dat de i-component groter was bij de gestructureerde beoordelingsmethoden dan bij het vrije oordeel, kon uitgaande van de beduidend kleinere variantiecomponent voor het ij-interactie-effect bij de gestructureerde beoordelingsmethoden worden verwacht, dat de verschillen tussen de beoordelingsmethoden zouden afnemen. De resultaten van beide D-studies zijn weergegeven in de tabellen 5.11 en 5.12 . 
Tabel 5.11: Coëfficiënten phi als een functie van het aantal casus en beoordelaars bij een volledig gekruist $\mathrm{p} \times \mathrm{i} \times \mathrm{j}$-design, voor de drie groepen beoordelaars.

\begin{tabular}{|c|c|c|c|c|c|c|c|c|}
\hline \multirow{3}{*}{$\begin{array}{l}\text { aantal } \\
\text { casus }\end{array}$} & \multicolumn{8}{|c|}{ Beoordelingsmethode } \\
\hline & \multicolumn{2}{|c|}{ vrije oordeel } & \multicolumn{2}{|c|}{$\begin{array}{c}\text { korte } \\
\text { antwoord } \\
\text { sleutel }\end{array}$} & \multicolumn{2}{|c|}{$\begin{array}{l}\text { ingedikte } \\
\text { criterialijst }\end{array}$} & \multicolumn{2}{|c|}{$\begin{array}{l}\text { uitgebreide } \\
\text { criterialijst }\end{array}$} \\
\hline & $\begin{array}{l}\text { eén } \\
\text { beoor }\end{array}$ & $\begin{array}{l}\text { twee } \\
\text { elaars }\end{array}$ & $\begin{array}{l}\text { eén } \\
\text { beoor }\end{array}$ & $\begin{array}{l}\text { twee } \\
\text { laars }\end{array}$ & $\begin{array}{l}\text { eén } \\
\text { beoor }\end{array}$ & $\begin{array}{l}\text { twee } \\
\text { laars }\end{array}$ & $\begin{array}{l}\text { én } \\
\text { beoor }\end{array}$ & $\begin{array}{l}\text { twee } \\
\text { laars }\end{array}$ \\
\hline & \multicolumn{8}{|c|}{ huisartsen als beoordelaars } \\
\hline 4 & 0.21 & 0.31 & 0.17 & 0.19 & 0.13 & 0.14 & 0.17 & 0.19 \\
\hline 8 & 0.27 & 0.40 & 0.27 & 0.31 & 0.20 & 0.24 & 0.27 & 0.31 \\
\hline 12 & 0.31 & 0.45 & 0.34 & 0.39 & 0.26 & 0.31 & 0.33 & 0.38 \\
\hline \multirow[t]{2}{*}{40} & 0.37 & 0.53 & 0.52 & 0.61 & 0.42 & 0.52 & 0.50 & 0.59 \\
\hline & \multicolumn{8}{|c|}{ geneeskunde studenten als beoordelaars } \\
\hline 4 & 0.16 & 0.25 & 0.19 & 0.23 & 0.20 & 0.22 & 0.13 & 0.17 \\
\hline 8 & 0.19 & 0.30 & 0.27 & 0.34 & 0.32 & 0.35 & 0.17 & 0.24 \\
\hline 12 & 0.20 & 0.32 & 0.31 & 0.40 & 0.41 & 0.44 & 0.19 & 0.28 \\
\hline \multirow[t]{2}{*}{40} & 0.22 & 0.36 & 0.40 & 0.54 & 0.63 & 0.69 & 0.23 & 0.36 \\
\hline & \multicolumn{8}{|c|}{ economie studenten als beoordelaars } \\
\hline 4 & 0.25 & 0.34 & 0.12 & 0.15 & 0.12 & 0.16 & 0.17 & 0.20 \\
\hline 8 & 0.32 & 0.44 & 0.16 & 0.22 & 0.19 & 0.25 & 0.26 & 0.31 \\
\hline 12 & 0.35 & 0.48 & 0.19 & 0.26 & 0.22 & 0.30 & 0.31 & 0.38 \\
\hline 40 & 0.41 & 0.57 & 0.24 & 0.36 & 0.31 & 0.44 & 0.44 & 0.56 \\
\hline
\end{tabular}

* 4 casus is ongeveer 1 uur toetstijd.

De op basis van de variantiecomponenten verwachte trend, dat de verschillen tussen de gestructureerde beoordelingsmethoden en het vrije oordeel zouden afnemen is in bovenstaande tabellen waarneembaar.

Tabel 5.11 laat zien dat bij het gekruiste design voor alle drie de groepen beoordelaars met het vrije oordeel de hoogste totale betrouwbaarheid werd verkregen. In tegenstelling tot het norm georiënteerde perspectief, werd bij de huisartsen onder het domein georienteerde perspectief vrijwel dezelfde totale betrouwbaarheid gevonden bij de korte antwoordsleutel en de uitgebreide criterialijst. Evenals onder het norm georiënteerde perspectief werd bij deze groep beoordelaars de laagste totale betrouwbaarheid verkregen met de ingedikte criterialijst. Bij de geneeskunde studenten werden onder het norm georiënteerde perspectief de grootste coëfficiënten verkregen met de ingedikte criterialijst en de korte antwoordsleutel. Dit in tegenstelling tot onder het domein georiënteerde perspectief 
waarbij de hoogste totale betrouwbaarheid werd verkregen met het vrije oordeel, gevolgd door de ingedikte criterialijst. Dit resultaat leek voor een belangrijk deel te worden veroorzaakt door de relatief grote $\mathrm{ij}$-component bij het vrije oordeel. Bij de economie studenten leidde het vrije oordeel wederom tot de hoogste totale betrouwbaarheid. In tegenstelling tot onder het norm georiënteerde perspectief werd bij deze groep beoordelaars met zowel de korte antwoordsleutel als de ingedikte criterialijst de minst betrouwbare resultaten verkregen. Dit leek met name te kunnen worden toegeschreven aan de relatief lage i-component en de relatief kleine ij-component bij de uitgebreide criterialijst.

Kortom, zoals op voorhand werd verwacht, werd bij het gekruiste design onder een domein georiënteerd perspectief lagere betrouwbaarheidscoëfficiënten gevonden en werden de verschillen tussen de vier beoordelingsmethoden minder groot.

Tabel 5.12: Coëfficiënten phi als een functie van het aantal casus en beoordelaars bij een genest p x j:i-design, voor de drie groepen beoordelaars.

\begin{tabular}{|c|c|c|c|c|c|c|c|c|}
\hline \multirow{3}{*}{$\begin{array}{c}\text { aantal } \\
\text { casus }\end{array}$} & \multicolumn{8}{|c|}{ Beoordelingsmethode } \\
\hline & \multicolumn{2}{|c|}{ vrije oordeel } & \multicolumn{2}{|c|}{$\begin{array}{c}\text { korte } \\
\text { antwoord } \\
\text { sleutel }\end{array}$} & \multicolumn{2}{|c|}{$\begin{array}{c}\text { ingedikte } \\
\text { criterialijst }\end{array}$} & \multicolumn{2}{|c|}{$\begin{array}{l}\text { uitgebreide } \\
\text { criterialijst }\end{array}$} \\
\hline & $\begin{array}{l}\text { én } \\
\text { beoo }\end{array}$ & $\begin{array}{l}\text { twee } \\
\text { elaars }\end{array}$ & $\begin{array}{l}\text { eén } \\
\text { beoo }\end{array}$ & $\begin{array}{l}\text { twee } \\
\text { laars }\end{array}$ & $\begin{array}{l}\text { eén } \\
\text { beoo }\end{array}$ & $\begin{array}{l}\text { twee } \\
\text { elaars }\end{array}$ & $\begin{array}{l}\text { én } \\
\text { beoor }\end{array}$ & $\begin{array}{l}\text { twee } \\
\text { elaars }\end{array}$ \\
\hline & \multicolumn{8}{|c|}{ huisartsen als beoordelaars } \\
\hline 4 & 0.27 & 0.38 & 0.18 & 0.20 & 0.14 & 0.15 & 0.19 & 0.20 \\
\hline 8 & 0.43 & 0.55 & 0.31 & 0.33 & 0.24 & 0.26 & 0.31 & 0.33 \\
\hline 12 & 0.53 & 0.64 & 0.40 & 0.42 & 0.32 & 0.35 & 0.41 & 0.43 \\
\hline \multirow[t]{2}{*}{40} & 0.79 & 0.86 & 0.69 & 0.71 & 0.61 & 0.64 & 0.70 & 0.71 \\
\hline & \multicolumn{8}{|c|}{ geneeskunde studenten als beoordelaars } \\
\hline 4 & 0.27 & 0.38 & 0.23 & 0.26 & 0.21 & 0.22 & 0.19 & 0.22 \\
\hline 8 & 0.42 & 0.54 & 0.37 & 0.41 & 0.34 & 0.36 & 0.32 & 0.36 \\
\hline 12 & 0.53 & 0.64 & 0.47 & 0.51 & 0.44 & 0.46 & 0.41 & 0.45 \\
\hline \multirow[t]{2}{*}{40} & 0.79 & 0.86 & 0.75 & 0.78 & 0.72 & 0.74 & 0.70 & 0.73 \\
\hline & \multicolumn{8}{|c|}{ economie studenten als beoordelaars } \\
\hline 4 & 0.33 & 0.41 & 0.15 & 0.18 & 0.15 & 0.18 & 0.19 & 0.21 \\
\hline 8 & 0.50 & 0.58 & 0.26 & 0.31 & 0.27 & 0.31 & 0.32 & 0.35 \\
\hline 12 & 0.60 & 0.67 & 0.35 & 0.39 & 0.34 & 0.39 & 0.41 & 0.45 \\
\hline 40 & 0.83 & 0.87 & 0.64 & 0.68 & 0.64 & 0.68 & 0.70 & 0.73 \\
\hline
\end{tabular}

* 4 casus is ongeveer 1 uur toetstijd. 
In tabel 5.12 staan de resultaten weergegeven van het geneste-design onder een domein georiënteerd perspectief.

$\mathrm{Bij}$ het geneste design is de variantiecomponent voor het hoofdeffect beoordelaars (j) niet af te zonderen van de $\mathrm{ij}$-component. Bij een vergelijking van de totale betrouwbaarheid onder een norm en een domein georiënteerd perspectief worden de verschillen dan ook hoofdzakelijk door de verschillen in de i-component verklaard, daar de componenten waarin de beoordelaar een rol speelt reeds bij de berekening onder een norm georiënteerd perspectief zijn meegenomen. De coëfficiënten phi bij het geneste design lieten vrijwel eenzelfde beeld zien als de generaliseerbaarheidscoëfficiënten bij het norm georiënteerde perspectief. Bij alle drie de groepen beoordelaars werden verreweg de hoogste coëfficiënten gevonden bij het vrije oordeel. Van de gestructureerde beoordelingsmethoden leverden bij de huisartsen de uitgebreide criterialijst en de korte antwoordsleutel de hoogste betrouwbaarheidsindices op. De coëfficiënten namen bij de geneeskunde studenten af naarmate de beoordelingsmethoden meer werden gestructureerd. In tegenstelling tot bij het norm georiënteerde perspectief, resulteerde bij de economie studenten de uitgebreide criterialijst in de hoogste coëfficiënten, na het vrije oordeel.

\subsection{Betrouwbaarheid van zak/slaag-beslissingen}

Voordat de betrouwbaarheid van de genomen zak/slaag-beslissingen bij bepaaide cesuren werd onderzocht, werd eerst de relatie tussen de gehanteerde cesuur en het aantal geslaagden bestudeerd. In paragraaf 5.6.2 werd geconstateerd, dat de gemiddelde score verschilde per beoordelingsmethode. Dit zou consequenties moeten hebben voor het aantal personen dat slaagt of zakt voor de toets. De aantallen geslaagden en gezakten per beoordelingsmethode en per beoordelaarsgroep voor de jaargroepen 4 en 6 zijn weergegeven in tabel 5.13 .

Uit tabel 5.13 blijkt, dat bij elke jaargroep het aantal geslaagden het grootst was bij het vrije oordeel en dat dit aantal afnam naarmate de beoordelingsmethode meer was gestructureerd, ongeacht de medische expertise van de beoordelaars. Doordat de economie studenten bij het vrije oordeel gemiddeld hogere scores toekenden dan de geneeskunde studenten en de huisartsen, was het slaagpercentage bij het vrije oordeel het hoogst bij de economie studenten. Tussen de geneeskunde studenten en de huisartsen was slechts een gering verschil vast te stellen. Bij de gestructureerde beoordelingsmethoden waren slechts geringe verschillen in het aantal geslaagden waameembaar tussen de huisartsen, de geneeskunde studenten en de economie studenten, hoewel de huisartsen iets strenger bleken te zijn.

Op basis van deze gegevens werd voorlopig geconcludeerd, dat het bepalen van een zak/slaag-grens mede afhankelijk dient te zijn van de gehanteerde beoordelingsmethode. 
Tabel 5.13: Het aantal geslaagden bij verschillende zak/slaag-grenzen voor jaargroep $4(n=40)$ en jaargroep $6(n=40)$.

\begin{tabular}{|c|c|c|c|c|c|c|c|c|}
\hline \multirow{4}{*}{$\begin{array}{l}\text { Beoordelings- } \\
\text { methode }\end{array}$} & \multicolumn{8}{|c|}{ Grenswaarde } \\
\hline & \multicolumn{2}{|c|}{$30 \%$} & \multicolumn{2}{|c|}{$40 \%$} & \multicolumn{2}{|c|}{$50 \%$} & \multicolumn{2}{|c|}{$60 \%$} \\
\hline & jrg 4 & jrg 6 & jrg 4 & jrg 6 & jrg 4 & jrg 6 & jrg 4 & jrg 6 \\
\hline & \multicolumn{8}{|c|}{ huisartsen als beoordelaars } \\
\hline Vrije oordeel & 40 & 40 & 38 & 40 & 29 & 38 & 6 & 22 \\
\hline korte antw. sl. & 32 & 40 & 12 & 36 & 2 & 14 & 0 & 0 \\
\hline ing. crit. lijst & 31 & 40 & 11 & 29 & 2 & 10 & 0 & 0 \\
\hline \multirow[t]{2}{*}{ uitg. crit. lijst } & 22 & 40 & 2 & 22 & 0 & 2 & 0 & 0 \\
\hline & \multicolumn{8}{|c|}{ geneeskunde studenten als beoordelaars } \\
\hline vrije oordeel & 40 & 40 & 38 & 40 & 27 & 37 & 5 & 18 \\
\hline korte antw. sl. & 28 & 39 & 12 & 32 & 2 & 14 & 0 & 0 \\
\hline ing. crit. lijst & 29 & 40 & 12 & 31 & 2 & 9 & 0 & 0 \\
\hline \multirow[t]{2}{*}{ uitg. crit. lijst } & 25 & 40 & 7 & 26 & 2 & 10 & 0 & 0 \\
\hline & \multicolumn{8}{|c|}{ economie studenten als beoordelaars } \\
\hline vrije oordeel & 40 & 40 & 40 & 40 & 35 & 39 & 19 & 30 \\
\hline korte antw. sl. & 31 & 39 & 8 & 28 & 0 & 10 & 0 & 0 \\
\hline ing. crit. lijst & 23 & 37 & 5 & 19 & 0 & 2 & 0 & 0 \\
\hline uitg. crit. lijst & 19 & 40 & 5 & 24 & 0 & 2 & 0 & 0 \\
\hline
\end{tabular}

Naast deze kwantitatieve aspecten van de verschillende zak/slaag-grenzen werd eveneens aandacht besteed aan de betrouwbaarheid waarmee bij verschillende cesuren, zak/slaagbeslissingen konden worden genomen. Bij deze berekeningen werd uitgegaan van een toetslengte van acht casus. De resultaten van deze analyse zijn weergegeven in tabel 5.14.

De betrouwbaarheid varieerde sterk per beoordelingsmethode bij de verschillende zak/slaag-grenzen. Desondanks was het met elke beoordelingsmethode mogelijk tot zeer betrouwbare beslissingen te komen. De betrouwbaarheid van de beslissing nam echter af naarmate de cesuur dichter bij het gemiddelde kwam te liggen. Dit betekende dat de betrouwbaarheid van een genomen beslissing per student verschilde, aangezien de score van de ene student dichter bij de cesuur lag dan de score van een andere persoon.

De standaardmeetfout van deze korte casustoets was relatief groot, waardoor grote verschillen tussen de diverse zak/slaag-grenzen werden gevonden. Indien de toets langer zou zijn (en de standaardmeetfout dus kleiner zou worden), zou mogen worden verwacht dat deze verschillen beduidend kleiner zijn. 
Tabel 5.14: Betrouwbaarheid van de genomen zak/slaag-beslissing bij verschillende cesuren per beoordelingsmethode voor elke groep beoordelaars, bij een toets bestaande uit acht casus.

\section{Beoordelings- methode}

Grenswaarde

\begin{tabular}{|c|c|c|c|}
\hline $30 \%$ & $40 \%$ & $50 \%$ & $60 \%$ \\
\hline
\end{tabular}

huisartsen als beoordelaars

$\begin{array}{lllllllll}\text { Vrije oordeel } & 0.84 & 0.96 & 0.61 & 0.59 & 0.12 & 0.62 & 0.55 & 0.21 \\ \text { korte antw. sl. } & 0.67 & 0.85 & 0.44 & 0.56 & 0.81 & 0.25 & 0.92 & 0.58 \\ \text { ing. crit. lijst } & 0.52 & 0.81 & 0.29 & 0.28 & 0.79 & 0.15 & 0.92 & 0.78 \\ \text { uitg. crit. lijst } & 0.16 & 0.79 & 0.70 & 0.25 & 0.90 & 0.64 & 0.96 & 0.89\end{array}$

geneeskunde studenten als beoordelaars

$\begin{array}{lllllllll}\text { vrije oordeel } & 0.85 & 0.94 & 0.61 & 0.90 & 0.00 & 0.76 & 0.34 & 0.21 \\ \text { korte antw. sl. } & 0.52 & 0.85 & 0.35 & 0.53 & 0.79 & 0.06 & 0.92 & 0.71 \\ \text { ing. crit. lijst } & 0.45 & 0.84 & 0.35 & 0.60 & 0.81 & 0.11 & 0.92 & 0.73 \\ \text { uitg. crit. lijst } & 0.09 & 0.55 & 0.56 & 0.00 & 0.86 & 0.16 & 0.94 & 0.71\end{array}$

economie studenten als beoordelaars

$\begin{array}{lllllllll}\text { vrije oordeel } & 0.95 & 0.96 & 0.91 & 0.92 & 0.76 & 0.84 & 0.44 & 0.52 \\ \text { korte antw. sl. } & 0.00 & 0.67 & 0.00 & 0.00 & 0.69 & 0.19 & 0.87 & 0.76 \\ \text { ing. crit. lijst } & 0.19 & 0.68 & 0.60 & 0.03 & 0.88 & 0.68 & 0.94 & 0.89 \\ \text { uitg. crit. lijst } & 0.21 & 0.74 & 0.65 & 0.07 & 0.89 & 0.67 & 0.95 & 0.90\end{array}$

\subsubsection{Weging}

Zoals eerder is beschreven waren de categorieën van de gestructureerde beoordelingsmethoden van positieve wegingsfactoren voorzien. Om de invloed van positieve weging te kunnen onderzoeken werd de aangebrachte weging omgezet in een neutrale weging. Dit betekende dat voor elke categorie in de gestructureerde beoordelingsmethode maximaal 100 punten kon worden toegekend.

Allereerst werd voor elke groep beoordelaars per beoordelingsmethode het gemiddelde en de bijbehorende standaarddeviatie van het gemiddelde berekend, uitgaande van de ongewogen scores. De resultaten van de ongewogen beoordelingen zijn weergegeven in tabel 5.15 en de figuren $5.4 \mathrm{t} / \mathrm{m} 5.6$. 
Tabel 5.15: Gemiddelde scores en standaarddeviaties per beoordelingsmethode voor elke jaargroep uitgesplitst per groep beoordelaars, uitgaande van de ongewogen scores.

\begin{tabular}{|c|c|c|c|c|c|c|}
\hline \multirow[t]{3}{*}{ Beoordelingsmethode } & \multicolumn{6}{|c|}{ Jaargroep } \\
\hline & \multicolumn{2}{|c|}{1} & \multicolumn{2}{|c|}{4} & \multicolumn{2}{|c|}{6} \\
\hline & Gem. & Sd. & Gem. & $\mathrm{Sd}$ & Gem. & $\mathrm{Sd}$. \\
\hline & \multicolumn{6}{|c|}{ huisartsen als beoordelaars } \\
\hline vrije oordeel & 22.38 & 11.60 & 50.62 & 18.03 & 57.78 & 11.08 \\
\hline korte antwoord sleutel & 17.40 & 11.40 & 38.48 & 20.89 & 44.38 & 22.97 \\
\hline ingedikte crit. & 17.44 & 12.82 & 41.90 & 21.83 & 48.53 & 22.41 \\
\hline uitgebreide crit. & 12.13 & 13.08 & 34.10 & 21.70 & 41.66 & 22.51 \\
\hline
\end{tabular}

geneeskunde studenten als beoordelaars

$\begin{array}{lrrrrrr}\text { vrije oordeel } & 24.85 & 13.27 & 52.19 & 17.97 & 57.65 & 12.71 \\ \text { korte antwoord sleutel } & 18.09 & 12.43 & 39.27 & 18.79 & 45.95 & 19.43 \\ \text { ingedikte crit. } & 17.29 & 11.42 & 38.43 & 20.33 & 47.16 & 20.55 \\ \text { uitgebreide crit. } & 11.71 & 6.28 & 33.82 & 14.01 & 39.56 & 13.52\end{array}$

economie studenten als beoordelaars

$\begin{array}{lllllll}\text { vrije oordeel } & 34.08 & 21.15 & 60.95 & 17.56 & 68.83 & 13.49 \\ \text { korte antwoord sleutel } & 18.58 & 14.52 & 37.41 & 21.96 & 42.83 & 23.18 \\ \text { ingedikte crit. } & 14.93 & 11.60 & 36.23 & 15.63 & 41.42 & 17.72 \\ \text { uitgebreide crit. } & 11.72 & 11.12 & 35.16 & 22.25 & 40.87 & 21.87\end{array}$

Evenals bij de gewogen beoordelingen bleek bij de ongewogen beoordelingen binnen jaargroepen een redelijke spreiding in de behaalde scores te bestaan. De mate van spreiding varieerde echter per beoordelingsmethode, per jaargroep en per groep beoordelaars. Ook met de ongewogen beoordelingen werden duidelijke verschillen tussen jaargroepen gevonden, zij het dat niet met elke beoordelingsmethode een even groot onderscheid tussen de jaargroepen werd aangebracht. Bij alle drie de groepen beoordelaars werden verreweg de hoogste gemiddelde scores gegeven bij het vrije oordeel.

Bij vergelijking van de resultaten in tabel 5.15 met de resultaten in tabel 5.2 bleek, dat bij de ongewogen beoordelingen de eerste- en vierdejaars studenten gemiddeld hogere scores behaalden dan bij de gewogen beoordelingen, ongeacht de groep beoordelaars. De zesdejaars studenten behaalden daarentegen gemiddeld lagere scores dan met de gewogen beoordelingen. Aangezien de casustoets opgezet was als een instrument voor medisch probleemoplossen, werd op basis van deze resultaten voorlopig geconcludeerd, dat het 
aanbrengen van weging het discriminerend vermogen verhoogde en de validiteit van de beoordelingsmethoden positief beïnvloedde.

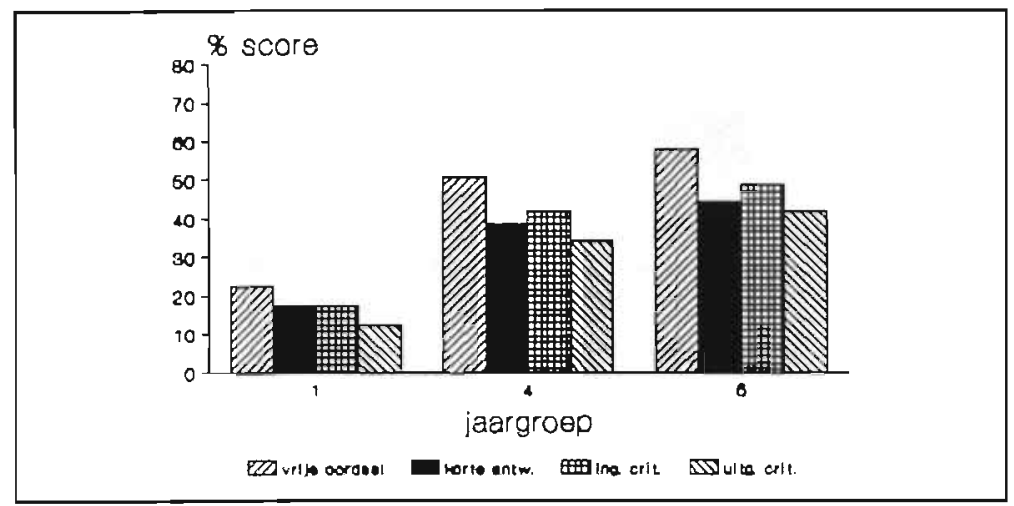

Figuur 5.4: Gemiddelde score voor elke jaargroep en beoordelingsmethode. toegekend door de huisartsen als beoordelaars. uitgaande van ongewogen scores.

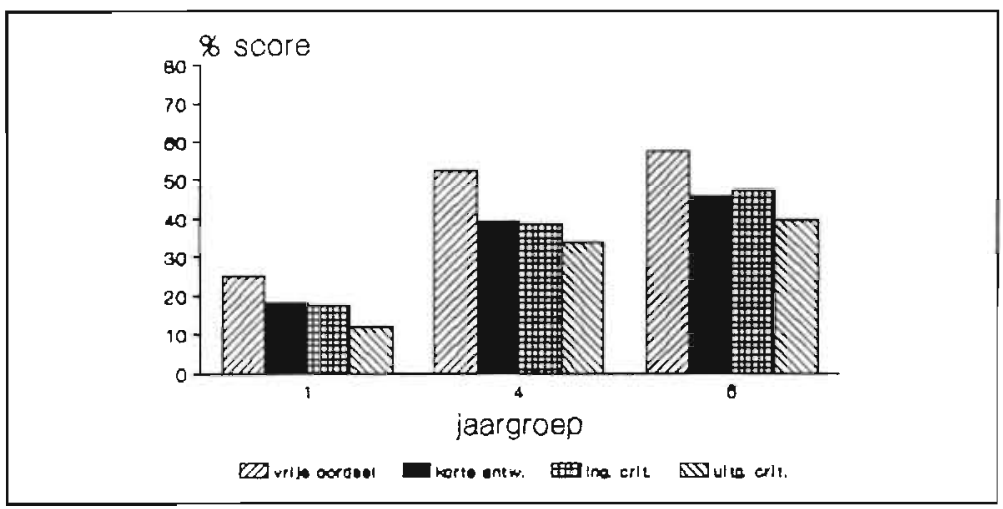

Figuur 5.5: Gemiddelde score voor elke jaargroep en beoordelingsmethode. toegekend door de geneeskunde studenten als beoordelaars, uitgaande vanongewogen scores. 


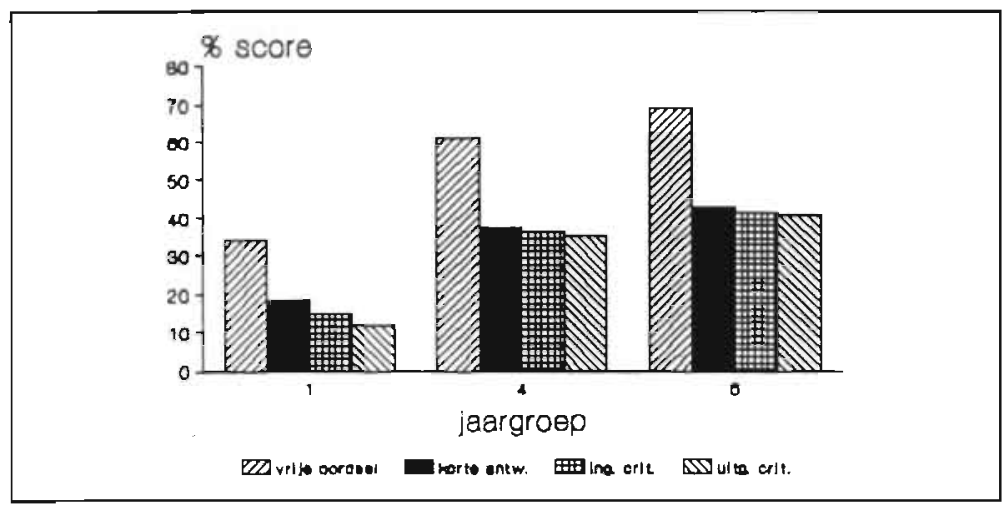

Figuur 5.6: Gemiddelde score voor elke jaargroep en beoordelingsmethode. toegekend door de economie studenten als beoordelaars. uitgaande van ongewogen scores.

Naast de gemiddelde scores en de bijbehorende standaarddeviaties werd de correlatie tussen de gewogen en de ongewogen scores bestudeerd. De gegevens zijn weergegeven in tabel 5.16 .

Tabel 5.16: Geobserveerde correlaties tussen de gewogen en de ongewogen scores voor elke groep beoordelaars per beoordelingsmethode.

Beoordelingsmethode

\begin{tabular}{|c|c|c|c|c|c|c|c|c|c|}
\hline & & $\begin{array}{l}\text { korte } \\
\text { twoo } \\
\text { sleute }\end{array}$ & & & $\begin{array}{l}\text { gedik } \\
\text { terial }\end{array}$ & & & $\begin{array}{l}\text { gebre } \\
\text { terial }\end{array}$ & \\
\hline & ha & gen & $\mathrm{ec}$ & ha & gen & ec & ha & gen & $\mathrm{ec}$ \\
\hline jaargroep $1^{\circ}$ & 0.57 & 0.65 & 0.65 & 0.69 & 0.53 & 0.52 & 0.71 & 0.68 & 0.67 \\
\hline jaargroep 4 “• & 0.47 & 0.43 & 0.51 & 0.47 & 0.51 & 0.43 & 0.49 & 0.50 & 0.46 \\
\hline jaargroep $6{ }^{\circ}$ & 0.52 & 0.68 & 0.42 & 0.41 & 0.44 & 0.37 & 0.42 & 0.36 & 0.38 \\
\hline $\begin{array}{l}\text { over alle } \\
\text { jaargroepen }\end{array}$ & 0.56 & 0.52 & 0.53 & 0.53 & 0.55 & 0.49 & 0.54 & 0.52 & 0.52 \\
\hline
\end{tabular}

* $\mathrm{n}=18$

** $n=40$

Uit tabel 5.16 blijkt dat de correlatie tussen de gewogen en de ongewogen scores over 
alle jaargroepen heen, varieerde van 0.49 tot en met 0.56 . Wat betreft de hoogte van de correlaties is weinig tot geen verschil waarneembaar tussen de drie beoordelingsmethoden, ongeacht de medische expertise van de beoordelaars. Het lijkt er op dat het al dan niet aanbrengen van wegingsfactoren invloed heeft op de rangordening van de studenten. In hoeverre de invloed op de rangordening van studenten per jaargroep verschilt, kan worden bestudeerd aan de hand van de correlatie tussen de gewogen en de ongewogen sores per jaargroep. Uit tabel 5.16 blijkt dat deze correlatie varieerde van 0.36 tot 0.71 . Voor alle drie de groepen beoordelaars gold dat de correlatie het hoogst was bij de eerstejaars studenten. Bij de huisartsen en de geneeskunde studenten werd bij de korte antwoordsleutel een hogere correlatie gevonden bij de zesdejaars studenten dan bij de vierdejaars studenten. Bij de ingedikte en de uitgebreide criterialijst nam de correlatie echter af naarmate de studenten meer medisch onderwijs hadden gevolgd, ongeacht de medische expertise van de beoordelaars. Op basis van deze resultaten werd geconcludeerd, dat het al dan niet aanbrengen van wegingsfactoren bij hogejaars studenten grotere invloed heeft op de rangordening van de studenten dan bij eerstejaars studenten.

Naast de correlatie tussen de gewogen en de ongewogen scores werd eveneens de correlatie tussen de verschillende beoordelingsmethoden bestudeerd, uitgaande van de ongewogen scores. De resultaten worden weergegeven in tabel 5.17.

Uit tabel 5.17 blijkt dat bij elke beoordelaarsgroep de correlaties tussen het vrije oordeel en de gestructureerde beoordelingsmethoden bijzonder laag waren, variërend van 0.10 tot 0.32 . Ook de correlaties tussen de gestructureerde beoordelingsmethoden waren niet hoog, met uitzondering van de geneeskunde studenten. De correlaties tussen de gestructureerde beoordelingsmethoden waren lager bij de ongewogen beoordelingen dan bij de gewogen beoordelingen, ongeacht de medische expertise van de beoordelaars. Wel bleken bij de inhoudsdeskundige beoordelaars de verschillen in de correlaties tussen de gewogen en de ongewogen beoordelingen groter te zijn dan bij de economie studenten.

Het leek te mogen worden verondersteld dat de correlatie tussen het vrije oordeel en de gestructureerde beoordelingsmethoden groter zou zijn bij de huisartsen dan bij de economie studenten. Verwacht zou mogen worden dat de huisartsen met het vrije oordeel meer relevante aspecten uit de studentantwoorden zouden herkennen dan leken. Uit de correlaties tussen de beoordelingsmethoden bij de ongewogen scores leek dit niet het geval te zijn: bij alle drie de groepen beoordelaars werden vrijwel gelijke (lage) correlaties gevonden tussen het vrije oordeel en de gestructureerde beoordelingsmethoden. Dit in tegenstelling tot de correlaties bij de gewogen beoordelingen waar wel de verwachte trend werd waargenomen. Deze resultaten vormden een ondersteuning voor de veronderstelling dat gewogen beoordelingen meer valide zijn.

Voorts werd bij elke beoordelingsmethode de correlatie tussen de drie groepen beoordelaars bepaald, uitgesplitst per jaargroep. Op deze wijze werd getracht inzicht te verkrijgen in hoeverre de verschillende groepen beoordelaars met eenzelfde beoordelingsmethode tot gelijke c.q. valide beoordelingen kwamen. De resultaten zijn weergegeven in tabel 5.18.

Uit tabel 5.18 blijkt dat de correlatie tussen de drie groepen beoordelaars varieerde van 0.22 tot 0.85 . Over het algemeen waren de correlaties bij de vierde- en zesdejaars studenten iets lager dan bij de gewogen scores, terwijl bij de eerstejaars de correlaties bij de meer gestructureerde methode nagenoeg dezelfde waren. 
Tabel 5.17: Geobserveerde correlaties tussen de verschillende beoordelingsmethoden, uitgaande van de ongewogen scores $(n=16)$.

huisartsen als beoordelaars

Beoordelingsmethode vrije oordeel korte antw. sleutel ingedikte crit. uitgebreide crit.

vrije oordeel

korte antw. sleutel $\quad 0.24$

ingedikte crit. $\quad 0.22$

$\begin{array}{llll}\text { uitgebreide crit. } & 0.32 & 0.64 & 0.68\end{array}$

geneeskunde studenten als beoordelaars

Beoordelingsmethode vrije oordeel korte antw. sleutel ingedikte crit. uitgebreide crit.

vrije oordeel

korte antw. sleutel $\quad 0.24$

ingedikte crit. $\quad 0.27 \quad 0.80$

$\begin{array}{llll}\text { uitgebreide crit. } & 0.32 & 0.78 & 0.75\end{array}$

economie studenten als beoordelaars

Beoordelingsmethode vrije oordeel korte antw. sleutel ingedikte crit. uitgebreide crit.

vrije oordeel

korte antw. sleutel $\quad 0.10$

ingedikte crit. $\quad 0.20$

uitgebreide crit. $\quad 0.23$

$0.65 \quad 0.63$

De correlaties bij het vrije oordeel waren hetzelfde als bij de gewogen scores, aangezien bij het vrije oordeel geen wegingsfactoren konden worden aangebracht. Voorts bleek dat bij de eerstejaars studenten het aanbrengen van meer structuur de correlatie tussen de drie groepen beoordelaars verlaagde. Zo werd bij de uitgebreide criterialijst de laagste correlatie gevonden. Bij de vierde- en zesdejaars studenten was de correlatie bij de gestructureerde modellen hoger dan bij het vrije oordeel. Tussen de gestructureerde beoordelingsmethoden waren slechts kleine verschillen waarneembaar in de correlatie tussen de huisartsen en de geneeskunde studenten. De correlatie tussen zowel de huisartsen als de geneeskunde studenten met de economie studenten nam beduidend toe naarmate de beoordelingsmethode meer was gestructureerd. 
Tabel 5.18: Geobserveerde correlaties tussen de drie groepen beoordelaars per jaargroep en per beoordelingsmethode, uitgaande van de ongewogen scores $(n=16)$.

\section{jaargroep 1}

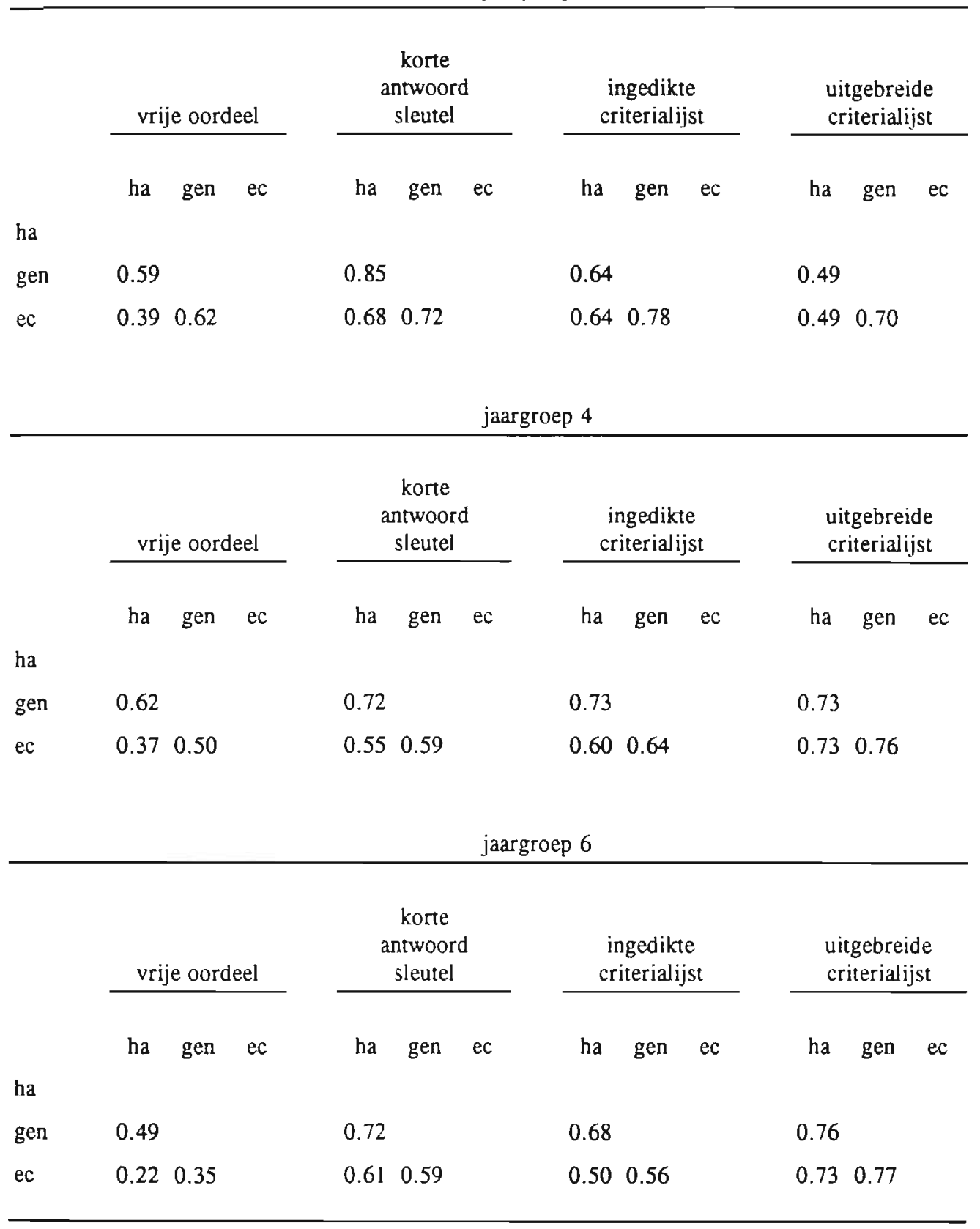




\subsubsection{Waardering van de beoordelingsmethoden}

Om een indruk te krijgen van de satisfactie van de beoordelaars over de beoordelingsmethoden werd de beoordelaars gevraagd de meegestuurde vragenlijst in te vullen. In deze vragenlijst was één vraag opgenomen met betrekking tot de benodigde nakijktijd. Daarnaast noteerden de beoordelaars, nadat ze twee casus met eén beoordelingsmethode hadden nagekeken hoeveel tijd het beoordelen in beslag had genomen. In figuur 5.7 is de benodigde nakijktijd per beoordelingsmethode weergegeven.

Uit figuur 5.7 blijkt dat het beoordelen met behulp van de gestructureerde beoordelingsmethoden meer tijd vergde dan het beoordelen met het vrije oordeel. Hoewel de economie studenten en de huisartsen de meeste tijd nodig hadden bij de uitgebreide criterialijst, kon niet worden gesteld, dat bij deze beoordelaars de nakijktijd toenam naarmate de beoordelingsmethode meer was gestructureerd. Verder bleken de drie groepen beoordelaars niet duidelijk te verschillen in de totale nakijktijd; alle drie de groepen hadden gemiddeld rond de zeven uur nodig om alle antwoorden na te kijken.

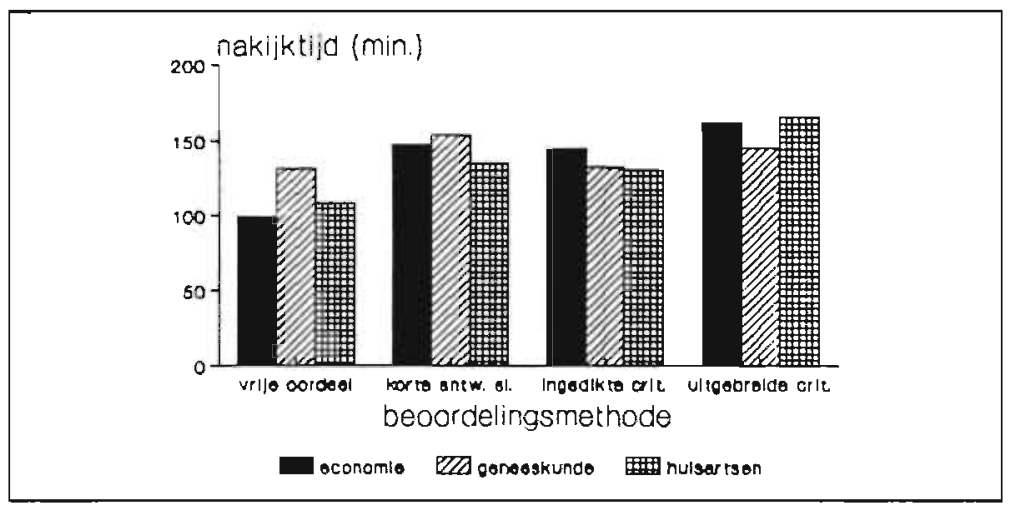

Figuur 5.7: Gemiddelde nakijktijd per beoordelingsmethode voor elke groep beoordelaars.

In hoeverre de beoordelaars het gevoel hadden dat hun inzicht tekort schoot bij het beoordelen met behulp van een bepaalde beoordelingsmethode, wordt weergegeven in figuur 5.8.

Uit figuur 5.8 blijkt dat de economie studenten het meeste het gevoel hadden dat hun inzicht tekort schoot bij het beoordelen, ongeacht de beoordelingsmethode. Bij deze groep beoordelaars was een trend waarneembaar dat dit gevoel afnam naarmate de beoordelingsmethode meer was gestructureerd. Over het algemeen waren de huisartsen van mening dat hun inzicht bij geen enkele beoordelingsmethode tekort schoot. De geneeskunde studenten waren eveneens van mening dat ze over voldoende inzicht beschikten, hoewel ze bij het vrije oordeel iets onzekerder waren dan bij de gestructureerde beoordelingsmethoden. 


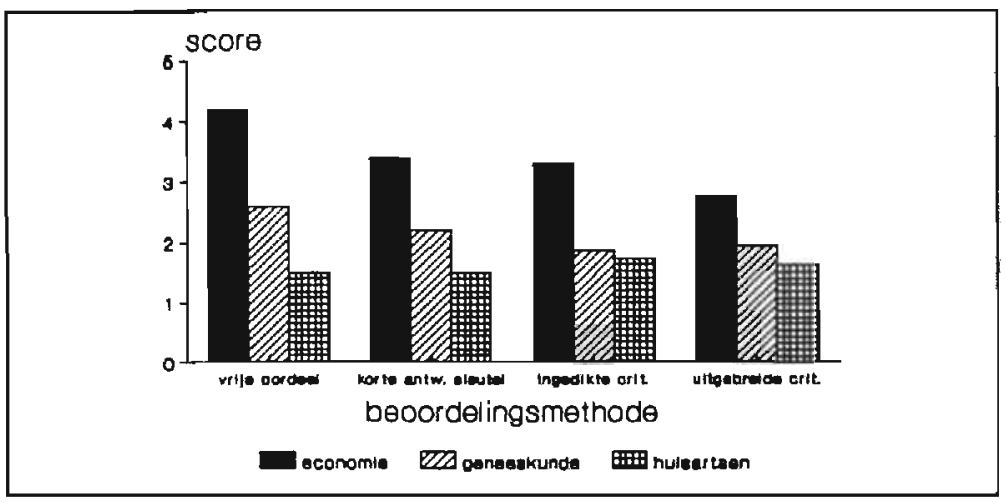

Figuur 5.8: De mate waarin het inzicht van de beoordelaars tekort schoot bij de verschillende beoordelingsmethode, uitgedrukt in een vijfpuntsschaal ( $1=$ zelden/nooit; $5=$ altijd $)$.

In hoeverre de beoordelaars de verschillende beoordelingsmethoden te weinig, voldoende of te veel gestructureerd vonden, wordt getoond in figuur 5.9.

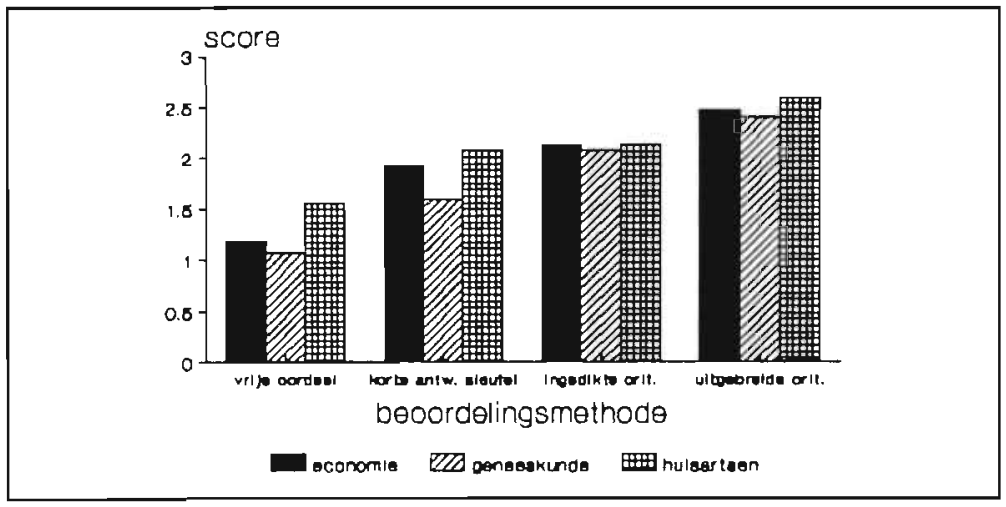

Figuur 5.9: De waardering van de drie groepen beoordelaars voor de mate van detaillering van de beoordelingsmethoden, uitgedrukt in een driepuntsschaal ( 1 = te weinig; $2=$ voldoende: 3 = (e veel).

Figuur 5.9 laat zien dat de beoordelaars de gestructureerde beoordelingsmethoden voldoende gedetailleerd of te gedetailleerd vonden. Het vrije oordeel werd over het algemeen als te weinig gedetailleerd ervaren. Opvallend was dat de economie studenten meer tevreden waren over de korte antwoordsleutel dan de geneeskunde studenten. Voor alle drie de groepen beoordelaars gold, dat de uitgebreide criterialijst regelmatig als te gedetailleerd werd ervaren, terwijl de korte antwoordsleutel en de ingedikte criterialijst voldoende structuur bood. 
Op de vraag naar de meest adequate beoordelingsmethode, was een ander antwoordpatroon waarneembaar.

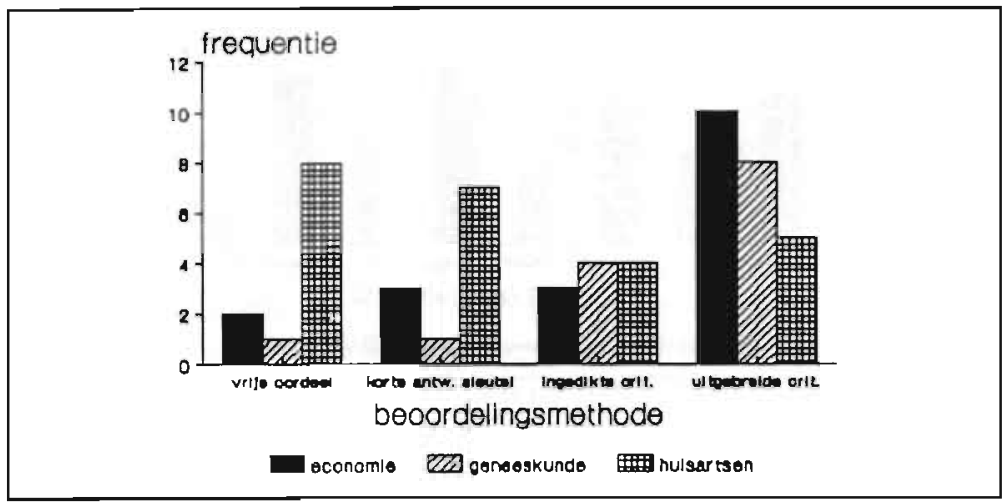

Figuur 5.10: Het aantal keren dat een beoordelingsmethode door een beoordelaar als het meest adequat wordt beoordeeld. uitgesplitst naar de groepen beoordelaars.

Zoals uit figuur 5.10 blijkt, vond het merendeel van de huisartsen het vrije oordeel $(n=8)$ en/of de korte antwoordsleutel $(n=7)$ de meest adequate beoordelingswijze. De geneeskunde studenten en de economie studenten waren daarentegen van mening dat de ingedikte en de uitgebreide criterialijst de beste beoordelingsmethoden waren. Kortom, de beoordelaars met de meeste medische expertise waren een duidelijk andere mening toegedaan dan de minder inhoudsdeskundige beoordelaars.

\subsection{Conclusies}

Voorafgaande aan het hoofdonderzoek werden 32 hypothesen geformuleerd die in het onderzoek moesten worden getoetst (zie 5.5). De consequenties van de resultaten voor de hypothesen wordt in deze paragraaf toegelicht.

\subsubsection{Validiteit}

Hypothese 1: De behaalde score op de casustoets is hoger naarmate de studenten meer medisch onderwijs hebben gevolgd.

Evenals in het pilot-onderzoek werd in het hoofdonderzoek een duidelijke stijging gevonden in de gemiddelde score op de acht casus met een groeiend aantal jaren gevolgd medisch onderwijs. De gegevens vormden een verificatie van de hypothese en konden tevens worden opgevat als een indicatie voor de theoretische validiteit van de casuïstiek.

Met betrekking tot de absolute hoogte van de behaalde scores door de studenten uit de drie jaargroepen werden twee hypothesen geformuleerd. Beide hypothesen worden 
hieronder gelijktijdig bediscussieerd.

Hypothese 2: De gemiddelde score op de casustoets neemt af naarmate de beoordelingsmethode meer is gestructureerd.

Hypothese 3: De verschillen tussen de jaargroepen zijn bij de gestructureerde beoordelingsmethoden meer geprononceerd dan bij het vrije oordeel.

Zoals werd verwacht nam de gemiddelde score voor elke jaargroep af naarmate de beoordelingsmethode meer was gestructureerd. De hoogte van de gemiddelde score verschilde echter voor de groepen beoordelaars. De door de geneeskunde studenten en economie studenten gegeven beoordelingen met het vrije oordeel waren met name bij de eerste- en vierdejaars studenten beduidend hoger dan de gegeven oordelen door de huisartsen. Bij de gestructureerde beoordelingsmethoden waren de verschillen tussen de drie groepen beoordelaars geringer, zij het dat de economie studenten met name de eersteen vierdejaars studenten hogere beoordelingen gaven in vergelijking met de andere twee groepen beoordelaars.

Met uitzondering van het vrije oordeel bij de economie studenten werd binnen elke groep beoordelaars met de beoordelingsmethoden nagenoeg eenzelfde onderscheid tussen studenten uit de drie jaargroepen aangebracht. De gegevens vormden een bevestiging van de hypothese dat de gemiddelde score afneemt naarmate de beoordelingsmethode meer is gestructureerd, maar falsificeerde de hypothese dat met de gestructureerde beoordelingsmethoden meer geprononceerde verschillen tussen jaargroepen zouden worden aangebracht.

Het discriminerend vermogen van de beoordelingsmethoden werd verder bestudeerd aan de hand van een discriminant-analyse. Van tevoren werd met betrekking tot het percentage juiste classificaties een drietal hypothesen geformuleerd.

Hypothese 4: Bij de inhoudsdeskundige beoordelaars leiden de korte antwoordsleutel en de ingedikte criterialijst tot het hoogste percentage juiste classificaties bij de discriminant-analyse.

Hypothese 5: Bij de economie studenten leidt de uitgebreide criterialijst tot het hoogste percentage juiste classificaties bij de discriminant-analyse.

Hypothese 6: Het vrije oordeel leidt tot het laagste percentage juiste classificaties bij de discriminant-analyse, ongeacht de medische expertise van de beoordelaars.

De discriminant-analyse leverde geen verschillen op tussen de beoordelingsmethoden wat betreft het onderscheidend vermogen. De huisartsen kwamen in het algemeen tot een iets hoger percentage juiste classificaties dan de geneeskunde en de economie studenten. De verschillen waren echter maximaal $10 \%(64.3 \%$ vs. $74.5 \%$ bij het vrije oordeel), maar bedroegen gemiddeld niet meer dan $4 \%$. Op grond van de resultaten moesten bovenstaande hypothesen worden verworpen. 
Hypothese 7: De correlaties tussen het vrije oordeel en de gestructureerde beoordelingsmethoden zijn lager dan de correlaties tussen de drie gestructureerde beoordelingsmethoden onderling.

De geobserveerde correlatie tussen het vrije oordeel en de gestructureerde beoordelingsmethoden was bij elke groep beoordelaars lager dan de geobserveerde correlatie tussen de gestructureerde beoordelingsmethoden onderling. De correlatie tussen het vrije oordeel en de gestructureerde beoordelingsmethoden varieerde van 0.33 tot 0.60 , terwijl de correlatie tussen de gestructureerde beoordelingsmethoden varieerde van 0.63 tot 0.87 . Met betrekking tot de ware correlatie werd een soortgelijke trend gevonden. Deze gegevens vormden een bevestiging van de hypothese en konden tevens worden op3evat als een indicatie voor het feit dat met het vrije oordeel gedeeltelijk iets anders werd gemeten dan met de gestructureerde beoordelingsmethoden.

\subsubsection{Generaliseerbaarheidsanalyses}

\subsubsection{G-studie}

Hypothese 8: De variantiecomponent behorende bij het hoofdeffect personen (p) is groter bij de gestructureerde beoordelingsmethoden dan bij het vrije oordeel.

In tegenstelling tot de verwachting werd in de G-studie de grootste variantiecomponent voor het hoofdeffect personen gevonden bij het vrije oordeel, ongeacht de medische expertise van de beoordelaars. De grootte van deze component bleek zelfs af te nemen bij de meer gestructureerde beoordelingsmethoden. Op basis van deze gegevens moest de hypothese worden verworpen.

Hypothese 9: De variantiecomponent behorende bij het hoofdeffect casus (i) is groter bij de gestructureerde beoordelingsmethoden dan bij het vrije oordeel.

Bij zowel de huisartsen als de geneeskunde studenten werd bij het vrije oordeel de kleinste variantiecomponent gevonden voor het hoofdeffect casus (i). Bij de huisartsen was deze component het grootst bij de korte antwoordsleutel, terwijl bij de geneeskunde studenten de ingedikte criterialijst tot de grootste i-component leidde. De economie studenten brachten eveneens het grootste onderscheid tussen casus aan met de korte antwoordsleutel. In tegenstelling tot de verwachtingen leidde bij deze groep beoordelaars de ingedikte en de uitgebreide criterialijst tot minder verschillen tussen de casus dan het vrije oordeel. Op grond van de gegevens van de huisartsen en de geneeskunde studenten werd de hypothese bevestigd, terwijl de gegevens van de economie studenten een falsificatie van de hypothese vormden.

De mate waarin onafhankelijke beoordelaars systematisch verschilden in de hoogte van de gegeven beoordelingen komt tot uitdrukking in de grootte van de variantiecomponent voor het hoofdeffect beoordelaars. Met betrekking tot de invloed van de relatie tussen de medische expertise van de beoordelaars en de mate van structurering van de beoordelings- 
methode op de grootte van deze component werd een drietal hypothesen geformuleerd.

Hypothese 10: De variantiecomponent behorende bij het hoofdeffect beoordelaars (j) is het grootst bij het vrije oordeel, ongeacht de medische expertise van de groep beoordelaars.

Hypothese 11: De variantiecomponent behorende bij het hoofdeffect beoordelaars is het kleinst bij de korte antwoordsleutel en de ingedikte criterialijst, bij de inhoudsdeskundige beoordelaars.

Hypothese 12: De variantiecomponent behorende bij het hoofdeffect beoordelaars is het kleinst bij de uitgebreide criterialijst voor de economie studenten.

In het onderzoek bleken bij de huisartsen en de geneeskunde studenten de verschillen in strengheid tussen de beoordelaars bij de gestructureerde beoordelingsmethoden kleiner te zijn dan bij het vrije oordeel. Bij de huisartsen was een trend waarneembaar dat de verschillen tussen de beoordelaars kleiner werden naarmate de beoordelingsmethode meer was gestructureerd, terwijl de geneeskunde studenten het minst verschilden bij de ingedikte criterialijst. Bij de economie studenten werden de grootste componenten gevonden bij respectievelijk de korte antwoordsleutel en het vrije oordeel. De grootte van de j-component was bij deze groep beoordelaars beduidend kleiner bij de twee meest gestructureerde beoordelingsmethoden en was het kleinst bij de uitgebreide criterialijst. De gegevens van het onderzoek vormden slechts een beperkte bevestiging van de hypothesen.

Hypothese 13: De inconsistentie van beoordelaars over personen neemt af naarmate de beoordelingsmethode meer is gestructureerd, ongeacht de medische expertise van de beoordelaars.

De beoordelaars kunnen al dan niet verschillen met betrekking tot de gehanteerde norm, ook in de rangordening van personen kunnen inconsistenties optreden. De mate waarin beoordelaars de personen anders rangordenden, is in het interactie-effect pj terug te vinden. Het pj-effect was voor elke groep beoordelaars het grootst bij het vrije oordeel. Tevens werd een interactie gevonden tussen de medische expertise van de beoordelaars en de mate van structurering waarbij het pj-effect het geringst was; bij de huisartsen werden de beste resultaten verkregen met de korte antwoordsleutel, bij de geneeskunde studenten leidde de ingedikte criterialijst tot de beste resultaten terwijl bij de economie studenten de uitgebreide criterialijst tot de meest consistente beoordelingen leidde. Deze gegevens vormden een beperkte bevestiging van de hypothese.

Hypothese 14: De inconsistentie van beoordelaars over casus neemt af naarmate de beoordelingsmethode meer is gestructureerd, ongeacht de medische expertise van de groep beoordelaars.

In hoeverre de beoordelaars verschillend beoordeelden over casus komt tot uitdrukking in het ij-interactie-effect. Het vrije oordeel leidde bij elke groep beoordelaars tot de grootste 
ij-component. Bij de gestructureerde beoordelingsmethode werd een gedifferentieerd beeld gevonden. De ingedikte criterialijst leidde bij de huisartsen tot de minste inconsistenties van de beoordelaars over casus heen. Beide andere groepen beoordelaars kwamen met de uitgebreide criterialijst tot de meest consistente beoordelingen. De hypothese dat de inconsistenties zouden afnemen naarmate de beoordelingsmethode meer was gestructureerd, werd door de gegevens gedeeltelijk bevestigd.

Hypothese 15: Het pi-effect is relatief groot bij elke beoordelingsmethode.

Het probleem van de inhoudsspecificiteit (Elstein et al., 1978) vormt een belangrijk obstakel bij de constructie van een adequaat meetinstrument voor medisch probleemoplossen. De mate waarin bij de gebruikte casustoets dit fenomeen optrad, komt tot uitdrukking in de hoogte van het interactie-effect pi. Tegen de verwachting in werd bij elke groep beoordelaars een beduidend kleinere pi-component gevonden bij het vrije oordeel dan bij de gestructureerde beoordelingsmethoden. Dit gold zowel voor de absolute grootte als de grootte van deze component ten opzichte van de andere variantiecomponenten. De resultaten van het vrije oordeel vormden een falsificatie van bovenstaande hypothese, terwijl de hypothese werd bevestigd door de resultaten van de gestructureerde beoordelingsmethoden.

Hypothese 16: De algemene error-variantie (pij) neemt af naarmate de beoordelingsmethode meer is gestructureerd, ongeacht de medische expertise van de groep beoordelaars.

De grootte van de algemene error-variantie geeft aan in welke mate tweede-orde-interactie-effecten en niet geïdentificeerde foutenbronnen het beoordelingsproces hebben beïnvloed. Bij elke groep beoordelaars was de algemene error-variantie kleiner bij de gestructureerde beoordelingsmethoden dan bij het vrije oordeel. Deze variantiecomponent was bij de huisartsen nagenoeg even groot bij de korte antwoordsleutel en de ingedikte criterialijst, terwijl bij de uitgebreide criterialijst een beduidend kleinere component werd gevonden. Bij de geneeskunde studenten was de pij-component het kleinst bij de ingedikte en de uitgebreide criterialijst. De grootte van de pij-component nam bij de economie studenten af naarmate de beoordelingsmethode meer was gestructureerd. De resultaten waren gedeeltelijk in overeenstemming met de verwachting, dat bij elke groep beoordelaars de pij-component zou afnemen naarmate de beoordelingsmethode meer was gestructureerd.

\subsubsection{Interbeoordelaarsbetrouwbaarheid}

Met behulp van de geschatte variantiecomponenten werd een aantal betrouwbaarheidsindices bepaald, zoals de interbeoordelaarsbetrouwbaarheid en de totale betrouwbaarheid. Met betrekking tot de interbeoordelaarsbetrouwbaarheid waren vier hypothesen geformuleerd.

Hypothese 17: De interbeoordelaarsbetrouwbaarheid is het laagst voor het vrije oordeel, ongeacht de medische expertise van de beoordelaars. 
Hypothese 18: De interbeoordelaarsbetrouwbaarheid voor de huisartsen is het hoogst bij de korte antwoordsleutel en de ingedikte criterialijst.

Hypothese 19: De interbeoordelaarsbetrouwbaarheid voor de geneeskunde studenten is het hoogst bij de korte antwoordsleutel en de ingedikte criterialijst.

Hypothese 20: Bij de economie studenten neemt de interbeoordelaarsbetrouwbaarheid toe naarmate de beoordelingsmethode meer is gestructureerd.

Uit de resultaten bleek dat bij de huisartsen de interbeoordelaarsbetrouwbaarheid toenam naarmate de beoordelingsmethode meer was gestructureerd. Bij de geneeskunde studenten leidde de ingedikte criterialijst tot de hoogste betrouwbaarheid. Evenals bij de huisartsen was bij de economie studenten de overeenstemming tussen beoordelaars het hoogst bij de uitgebreide criterialijst. Opmerkelijk was de hoge coëfficiënt bij het vrije oordeel bij de economie studenten (0.78) en de terugval bij dezelfde groep beoordelaars bij de ingedikte criterialijst. Deze bevindingen vormden geen bevestiging van de hypothese dat de interbeoordelaarsbetrouwbaarheid het hoogst zou zijn bij de korte antwoordsleutel en de ingedikte criterialijst voor de inhoudsdeskundige beoordelaars. De verwachting dat bij de economie studenten de hoogste coëfficiënt zou worden gevonden bij de uitgebreide criterialijst werd daarentegen wel bevestigd. Dit vormde echter een beperkte bevestiging van de hypothese, aangezien de interbeoordelaarsbetrouwbaarheid bij deze groep beoordelaars niet toenam naarmate de beoordelingsmethode meer was gestructureerd.

\subsubsection{Totale toetsbetrouwbaarheid}

In het onderzoek werd een viertal D-studies uitgevoerd waarin de invloed van het aantal casus en het aantal beoordelaars op de totale betrouwbaarheid werd bestudeerd. Voorafgaande aan het onderzoek werden met betrekking tot de totale betrouwbaarheid drie hypothesen geformuleerd.

Hypothese 21: De totale betrouwbaarheid is het hoogst bij de korte antwoordsleutel en de ingedikte criterialijst voor de inhoudsdeskundige beoordelaars.

Hypothese 22: De totale betrouwbaarheid is het hoogst bij de uitgebreide criterialijst voor de economie studenten.

Hypothese 23: Bij een domein georiënteerd perspectief is de daling van de totale betrouwbaarheid groter bij de gestructureerde beoordelingsmethoden dan bij het vrije oordeel, in vergelijking met een norm georiënteerd perspectief.

Het vrije oordeel leverde bij een volledig gekruist design en een norm georiënteerd perspectief de hoogste totale betrouwbaarheid op, ongeacht de expertise van de groep beoordelaars. Bij het hypothetische geneste design, waarbij elke beoordelaar slechts een beperkt aantal items beoordeelt, was bovenstaand effect nog nadrukkelijker waarneembaar. In beide $\mathrm{D}$-studies werden bij de drie gestructureerde beoordelingsmethoden slechts zeer geringe verschillen tussen de totale betrouwbaarheid gevonden. Deze bevindingen vormden geen bevestiging van de hypothese dat de totale betrouwbaarheid het hoogst zou 
zijn bij de korte antwoordsleutel en de ingedikte criterialijst voor de inhoudsdeskundige beoordelaars. Maar ook de hypothese dat bij de economie studenten de totale betrouwbaarheid zou toenemen naarmate de beoordelingsmethode meer zou zijn gestructureerd, werd door deze resultaten verworpen.

Hoewel ook bij beide $\mathrm{D}$-studies die werden uitgevoerd onder een domein georiënteerd perspectief het vrije oordeel tot de grootste generaliseerbaarheidscoëfficiënten leidde, vormden deze gegevens een gedeeltelijke bevestiging van de hypothesen. Indien alleen werd gekeken naar de gevonden coëfficiënten bij de gestructureerde beoordelingsmethoden was de volgende trend waarneembaar: de huisartsen boekten de beste resultaten met de korte antwoordsleutel, de geneeskunde studenten met de ingedikte criterialijst, terwijl de economie studenten het meest betrouwbaar beoordeelden met de uitgebreide criterialijst.

\subsubsection{Zak/slaag-beslissing}

Naast de validiteit en de betrouwbaarheid van de meting zijn in het onderzoek de consequenties van de gehanteerde beoordelingsmethode voor het aantal geslaagden en de betrouwbaarheid van de zak/slaag-beslissing bestudeerd. Met betrekking tot beide aspecten was een hypothese geformuleerd.

Hypothese 24: Het aantal studenten dat slaagt voor de casustoets is het grootst bij het vrije oordeel en het kleinst bij de uitgebreide criterialijst. ongeacht de medische expertise van de beoordelaars.

Hypothese 25: Naarmate de beoordelingsmethode meer is gestructureerd, neemt de betrouwbaarheid van de $\mathrm{zak} / \mathrm{slaag}$-beslissing af indien een lage cesuur ( $30 \%$ en $40 \%$ ) wordt gehanteerd.

Uitgaande van de veronderstelling dat de gemiddelde score daalt naarmate de beoordelingsmethode meer wordt gestructureerd, werd verwacht dat het aantal studenten dat zou slagen voor de casustoets het grootst zou zijn bij het vrije oordeel en het laagst bij de uitgebreide criterialijst. In het onderzoek werd inderdaad gevonden dat de gemiddelde score afnam naarmate meer structurering werd aangebracht. Als gevolg van deze verschillen in gemiddelde score nam het aantal geslaagden af naarmate de beoordelingsmethode meer was gestructureerd. De betrouwbaarheid van de genomen zak/slaagbeslissing bij de verschillende cesuren verschilde sterk per beoordelingsmethode als gevolg van de verschillen in de gemiddelde score. Bij alle drie de groepen beoordelaars werden de laagste betrouwbaarheden gevonden indien de studenten werden beoordeeld met een gestructureerde beoordelingsmethode en een cesuur van $30 \%$ of $40 \%$ werd gehanteerd. Deze gegevens waren gedeeltelijk in lijn met de in de hypothesen geformuleerde verwachtingen.

\subsubsection{Weging}

Beoordelaars zijn vaak geneigd het ene aspect zwaarder in een beoordeling mee te laten tellen dan een ander aspect. In het onderzoek werd de invloed van positieve weging op 
validiteit en betrouwbaarheid van de beoordelingen bestudeerd.

Hypothese 26: Het discriminerend vermogen van de gestructureerde beoordelingsmethoden neemt toe door het aanbrengen van positieve wegingsfactoren.

Uit de gemiddelde scores die op basis van de ongewogen beoordelingen werden verkregen, kwam naar voren dat zowel de eerste- als de vierdejaars studenten met deze becordelingsmethoden hogere scores kregen dan met de gewogen beoordelingen. Bij de zesdejaars studenten was het omgekeerde waarneembaar. Als gevolg hiervan kwamen de gemiddelde scores van de drie jaargroepen dichter bij elkaar te liggen. Deze resultaten werden opgevat als een bevestiging van de hypothese dat het aanbrengen van positieve weging het onderscheid tussen personen die beschikken over een verschillende mate van vaardigheid in medisch probleemoplossen vergroot.

Met betrekking tot de correlaties tussen de gewogen en de ongewogen scores waren twee hypothesen geformuleerd.

Hypothese 27: De correlatie tussen de gestructureerde beoordelingsmethoden is hoger op basis van de ongewogen scores dan op basis van de gewogen scores.

Hypothese 28: De correlatie tussen het vrije oordeel en de gestructureerde beoordelingsmethoden is hoger bij de ongewogen scores dan bij de gewogen scores.

De geobserveerde correlatie tussen de gestructureerde beoordelingsmethoden was bij elke groep beoordelaars hoger voor de gewogen scores dan voor de ongewogen scores. Deze verschillen waren het grootst bij de huisartsen en namen af naarmate de beoordelaars minder medische expertise bezaten. De correlaties tussen het vrije oordeel en de gestructureerde beoordelingsmethoden waren eveneens lager bij de ongewogen scores. Maar ook absoluut waren de correlaties laag. De correlatie tussen het vrije oordeel en de gestructureerde beoordelingsmethoden varieerde bij de huisartsen en de geneeskunde studenten tussen 0.22 en 0.32 , uitgaande van ongewogen scores en tussen 0.47 en 0.60 bij de gewogen scores. Bij de economie studenten varieerde de correlatie bij de ongewogen scores tussen 0.10 en 0.23 en tussen 0.33 en 0.51 bij de gewogen scores.

Deze resultaten falsificeerden beide hypotheses omtrent de correlatie.

\subsubsection{Waardering van de beoordelingsmethoden}

Met betrekking tot de waardering van de beoordelaars voor de verschillende beoordelingsmethoden, was een aantal hypothesen geformuleerd.

Hypothese 29: De korte antwoordsleutel en de ingedikte criterialijst worden door de inhoudsdeskundige beoordelaars ais het prettigst ervaren.

Hypothese 30: De uitgebreide criterialijst wordt door de economie studenten als het prettigst ervaren. 
Voor alle drie de groepen beoordelaars gold, dat zij de uitgebreide criterialijst het minst prettig vonden om mee te werken. Zowel de economie als de geneeskunde studenten waren van mening dat het vrije oordeel te weinig richtlijnen bood. Beide groepen beoordelaars prefereerden zowel de korte antwoordsleutel als de ingedikte criterialijst. De huisartsen vonden de korte antwoordsleutel het prettigst om mee te beoordelen. Deze gegevens vormden een beperkte bevestiging van bovenstaande hypothesen.

Over de mening van de beoordelaars omtrent de adequaatheid van de beoordelingsmethoden waren twee hypothesen geformuleerd.

Hypothese 31: De inhoudsdeskundige beoordelaars vinden dat de antwoorden van de studenten het meest adequaat kunnen worden beoordeeld met de korte antwoordsleutel en de ingedikte criterialijst.

Hypothese 32: De economie studenten vinden alle drie de gestructureerde beoordelingsmethoden even adequaat om de prestaties van de studenten te beoordelen.

Uit de resultaten bleek, dat acht huisartsen het vrije oordeel en zeven huisartsen de korte antwoordsleutel het meest adequaat vonden. De geneeskunde studenten vonden de ingedikte en de uitgebreide criterialijst het meest geschikt om studentprestaties te beoordelen. De uitgebreide criterialijst werd door de economie studenten verreweg als het meest adequaat ervaren. Wat betreft de overige drie beoordelingsmethoden hadden de economie studenten geen duidelijke voorkeur. Deze resultaten vormden een beperkte bevestiging van bovenstaande hypothesen.

Zoals in deze paragraaf verschillende malen is gebleken, zijn niet alle hypothesen behorende bij het onderzoek bevestigd. Het is de vraag welke consequenties deze resultaten hebben voor de vraagstellingen die aan het onderzoek ten grondslag lagen. Daamaast lijkt het zinvol om de resultaten in een breder kader te plaatsen. Met name de consequenties van deze gegevens voor de onderwijspraktijk, maar zeker ook op het verder te verrichten onderzoek verdient aandacht. In het volgende hoofdstuk zal dan ook op deze aspecten nader worden ingegaan. 


\section{DISCUSSIE EN CONCLUSIE}

\section{$6.1 \quad$ Inleiding}

Aan het onderzoek lag een zevental vraagstellingen ten grondslag. In de voorafgaande hoofdstukken is nader ingegaan op de verwachtingen, het onderzoeksdesign en de consequenties van de resultaten voor de geformuleerde hypothesen. In dit laatste hoofdstuk worden de vraagstellingen systematisch beantwoord. Daarnaast wordt ingegaan op de praktische bruikbaarheid van de resultaten voor de alledaagse onderwijspraktijk en worden suggesties voor nader onderzoek gedaan.

\subsection{Beantwoording van de vraagstellingen}

\subsubsection{Validiteit}

Met betrekking tot de invloed van structurering van beoordelingsmethoden op de validiteit van de beoordelingen werden twee vraagstellingen geformuleerd.

Vraagstelling 1: Welke invloed heeft structurering van beoordelingsmethoden op de validiteit van gegeven beoordelingen voor antwoorden op een schriftelijk simulatie-instrument voor het meten van de vaardigheid in medisch probleemoplossen, dat gebruik maakt van korte antwoordvragen?

Vraagstelling 2: Welke invloed heeft de deskundigheid c.q. medische expertise van de beoordelaar op de validiteit en in hoeverre wordt de relatie tussen medische expertise en de validiteit beïnvloed door de mate van structurering van de beoordelingsmethode?

Het structureren en formaliseren van het beoordelingsproces heeft doorgaans tot gevolg dat er een reductie plaatsvindt van de aspecten die worden beoordeeld. Dit betreft zowel het aantal als de aard van de aspecten (Hofstee, 1985). Het op deze wijze inperken van het beoordelingsproces zou een verlaging van de validiteit tot gevolg kunnen hebben. Daamaast heeft onderzoek aangetoond, dat een inperking van de vrijheid tijdens het beoordelingsproces tot meer accurate beoordelingen leidde (Cough, 1962; Wiggins, 1973; 
Nisbett \& Ross, 1980). Op grond van deze resultaten werd voorafgaande aan het onderzoek verwacht, dat met de gestructureerde beoordelingsmethoden meer accurate en zodoende meer valide uitspraken zouden worden verkregen. Hierdoor zou tevens het discriminerend vermogen van de beoordelingsmethoden toenemen. Op voorhand kon niet worden aangegeven welke mate van structurering tot de meest valide beoordelingen zou leiden. Verondersteld werd dat de behoefte aan structurering zou variëren met de inhoudsdeskundigheid van de beoordelaar.

In het onderzoek werden echter afwijkende resultaten verkregen. In tegenstelling tot de verwachting werd door elke groep beoordelaars met de gestructureerde beoordelingsmethoden minder onderscheid tussen studenten aangebracht dan met het vrije oordeel. Uit de correlaties tussen de beoordelingsmethoden kwam echter naar voren dat met het vrije oordeel gedeeltelijk iets anders werd gemeten dan met de gestructureerde methoden. In absolute zin waren de correlaties tussen de beoordelingsmethoden hoger dan in het pilotonderzoek. Op basis van deze resultaten wordt geconcludeerd, dat de lage correlaties in het pilot-onderzoek waren toe te schrijven aan de ongedifferentieerde weging van de subcategorieën (zie 4.7).

De vraag die vervolgens kan worden gesteld, is in hoeverre de resultaten een bevestiging vormden voor de validiteit of de invaliditeit van de gestructureerde beoordelingsmethoden.

Een antwoord op deze vraag kan onder andere worden verkregen uit de resultaten van de discriminant-analyse. In de discriminant-analyse werden echter geen verschillen tussen de beoordelingsmethoden gevonden. Deze resultaten leverden geen aanvullende informatie op omtrent de validiteit.

Bij bestudering van de variantiecomponenten kwam naar voren, dat bij het vrije oordeel zowel een grotere persoons- (ware variantie) als een grotere algemene error variantie werd gevonden dan bij de gestructureerde methoden. Daarentegen werd bij de gestructureerde methoden grotere componenten gevonden voor het pi-effect en werden de verschillen in de moeilijkheidsgraad van de casus meer geëxpliciteerd en de verschillen tussen beoordelaars teruggedrongen. De grootte van de pi-component bij de gestructureerde beoordelingsmethode was meer in overeenstemming met de in de literatuur beschreven bevindingen (Elstein et al., 1978; Swanson et al., 1989). Op basis hiervan lijken de gestructureerde beoordelingsmethoden meer valide te zijn (in de betekenis van aan te sluiten bij recent onderzoek). Opvallend was dat de verhouding tussen de grootte van de pi-component en de algemene error variantie bij het vrije oordeel omgekeerd was in vergelijking met die bij de gestructureerde methoden. Het lijkt er dan ook op dat het bieden van structuur de invloed van onbekende foutenbronnen terugdringt met als gevolg dat de error variantie meer kan worden verklaard. Dit biedt tevens de mogelijkheid om gericht te proberen de error variantie verder terug te dringen door te trachten de traceerbare foutenbronnen uit het beoordelingsproces te elimineren.

Naar aanleiding van de resultaten van het pilot-onderzoek werd de validiteit eveneens aan een extern criterium getoetst. Hiervoor werd de correlatie tussen de resultaten op de voortgangstoets van december 1989 en de casustoets gehanteerd. Met betrekking tot de hoogte van de correlaties was van tevoren geen expliciete verwachting geformuleerd. De resultaten laten zien dat de correlatie afneemt naarmate de studenten meer onderwijs hebben gevolgd, zowel zonder als met de correctie voor attenuatie. Deze trend werd echter bij alle vier de beoordelingsmethoden gevonden, zodat op basis hiervan geen 
onderscheid in de mate van validiteit tussen de beoordelingsmethoden kon worden aangebracht.

Door het ontbreken van een gouden standaard voor medisch probleemoplossen is het onmogelijk over de validiteit een absoluut zekere uitspraak te doen. Ondanks de grote ware variantie bij het vrije oordeel wordt hier op grond van de gevonden variantiecomponenten (met name de hoge algemene error variantie en de relatief lage pi-component bij het vrije oordeel) geconcludeerd, dat met de gestructureerde beoordelingsmethoden meer valide uitspraken werden verkregen.

\subsubsection{Generaliseerbaarheidsanalyses}

\subsubsection{G-studie}

Met betrekking tot de invloed van structurering van beoordelingsmethoden op de betrouwbaarheid waren twee vraagstelling aanwezig.

Vraagstelling 3: Wat is de invloed van de mate van structurering van de beoordelingsmethode op de betrouwbaarheid van een schriftelijk simulatie-instrument voor het meten van de vaardigheid in medisch probleemoplossen, dat gebruik maakt van korte antwoordvragen?

Vraagstelling 4: Welke invloed heeft de deskundigheid c.q. medische expertise van de beoordelaar op de betrouwbaarheid en in hoeverre wordt de relatie tussen medische expertise en betrouwbaarheid beïnvloed door de mate van structurering van de beoordelingsmethode?

\subsubsection{Interbeoordelaarsbetrouwbaarheid}

Het structureren van het beoordelingsproces kan naast voordelen eveneens nadelen opleveren. Zo wordt door beoordelaars een sterke beteugeling van het beoordelingsproces niet gewaardeerd. Het ontbreken van een beoordelingsvoorschrift blijkt evenals een te ver doorgevoerde structurering de kans op beoordelaarseffecten te vergroten (Cough, 1962; Wiggins, 1973; Nisbett \& Ross, 1980).

Op grond van bovenstaande onderzoeksgegevens werd het niet waarschijnlijk geacht, dat met het vrije oordeel een hoge interbeoordelaarsbetrouwbaarheid zou worden verkregen. Bij de huisartsen en de geneeskunde studenten werden soortgelijke resultaten verwacht met betrekking tot de uitgebreide criterialijst. Deze redenering kwam voort uit de gedachte, dat gezien de voorkennis van beide groepen beoordelaars, de uitgebreide criterialijst het beoordelingsproces te veel zou beteugelen. Bij beide groepen beoordelaars werd zowel bij de korte antwoordsleutel als de ingedikte criterialijst op hoge interbeoordelaarsbetrouwbaarheden gerekend.

Verhoudingsgewijs beschikken economie studenten over de minste medische expertise. Zodoende werd bij deze beoordelaarsgroep gerekend op een stijgende interbeoordelaarsbetrouwbaarheid naarmate de beoordelingsmethode meer was gestructureerd.

De resultaten van het onderzoek vormden slechts een gedeeltelijke bevestiging van de 
verwachtingen. Bij de huisartsen was de tendens waarneembaar dat de overeenstemming tussen de beoordelaars toenam naarmate het beoordelingsproces meer was gestructureerd. Bij de geneeskunde studenten werd de hoogste interbeoordelaarsbetrouwbaarheid verkregen met de ingedikte criterialijst. Zoals verwacht was de overeenstemming tussen de economie studenten het grootst bij de uitgebreide criterialijst. Dit vormde echter slechts een beperkte bevestiging van de hypothese, aangezien met de ingedikte criterialijst een lagere overeenstemming werd verkregen dan met de korte antwoordsleutel. Opvallend was de hoge betrouwbaarheid die bij de economie studenten werd verkregen met het vrije oordeel. Uitgaande van de bevindingen, dat de economie studenten met het vrije oordeel beduidend hogere scores toekenden dan de andere twee beoordelaarsgroepen, wordt deze hoge interbeoordelaarsbetrouwbaarheid toegeschreven aan een halo-effect (De Groot, 1965). Het leek er op dat de economie studenten eerder door een antwoord waren geimponeerd dan de deskundige beoordelaars.

De resultaten leverden geen bevestiging op voor de verwachting dat de overeenstemming tussen de meest inhoudsdeskundige beoordelaars zou dalen bij de uitgebreide criterialijst. Een mogelijke verklaring hiervoor is, dat de inhoudsdeskundige beoordelaars de uitgebreide criterialijst niet als een te sterke inperking van het beoordelingsproces ervaren. Dit zou het gevolg kunnen zijn van het feit dat de uitgebreide criterialijst geen echte checklist was. Daar staat tegenover dat de resultaten uit de vragenlijst lieten zien, dat de huisartsen met name de ingedikte en de uitgebreide criterialijst minder adequaat vonden.

Concluderend kan worden gesteld, dat minimale structurering van het beoordelingsproces de interbeoordelaarsbetrouwbaarheid doet toenemen en dat zelfs de meest gestructureerde beoordelingsmethode bij inhoudsdeskundige beoordelaars tot grote overeenstemming leidde.

\subsubsection{Totale toetsbetrouwbaarheid}

Beoordelaarseffecten kunnen de betrouwbaarheid van beoordelingen drastisch verlagen. Dit betekent echter niet dat indien een perfecte overeenstemming tussen beoordelaars wordt bereikt, het gegeven oordeel in alle opzichten betrouwbaar is. Naast beoordelaars hebben ook andere factoren invloed op de beoordeling, zoals de kwaliteit van de toets en de condities waarin de test is afgenomen. Kortom, een beoordelingsmethode waarmee de hoogste interbeoordelaarsbetrouwbaarheid wordt verkregen hoeft niet per definitie tot de hoogste totale betrouwbaarheid te leiden. In hoeverre een gelijke trend wordt gevonden hangt voornamelijk af van de relatieve bijdrage van beoordelaarseffecten ten opzichte van de andere foutenbronnen.

Van tevoren werd verwacht dat de ware variantie zou toenemen bij de meer gestructureerde beoordelingsmethoden en dat de error variantie zou afnemen. Tevens werd verwacht dat de invloed van beoordelaarseffecten geringer zou zijn bij de gestructureerde beoordelingsmethoden dan bij het vrije oordeel. Op grond hiervan werd verondersteld, dat wat betreft de totale variantie eenzelfde beeld zou worden verkregen als bij de interbeoordelaarsbetrouwbaarheid.

Deze verwachting werd echter niet bevestigd. Bij het vrije oordeel werd bij elke groep beoordelaars verreweg de hoogste totale betrouwbaarheid verkregen. De hoge coefficienten voor het vrije oordeel leken met name te kunnen worden toegeschreven aan de grote ware variantie en de lage pi-component. Door het feit dat het pi en het pij effect in verhouding een veel groter aandeel innamen dan het pj-effect, ontstond de opmerkelijke 
situatie dat, ongeacht de lage interbeoordelaarsbetrouwbaarheid, het vrije oordeel tot de hoogste totale toetsbetrouwbaarheid leidde.

Door de relatief lage interbeoordelaarsbetrouwbaarheid bij het vrije oordeel nam in een genest design het verschil in totale betrouwbaarheid tussen deze methode en de gestructureerde beoordelingsmethoden verder toe. Bij de gestructureerde beoordelingsmethoden werden geen verschillen in totale betrouwbaarheid gevonden ongeacht de medische expertise van de beoordelaars en het gehanteerde design.

Uit de resultaten kan worden geconcludeerd dat met het vrije oordeel tot betrouwbare beoordelingen kan worden gekomen. Op basis van deze resultaten kan tevens worden verondersteld, dat niet-experts tot betrouwbare beoordelingen kunnen komen indien het beoordelingsproces voldoende wordt gestructureerd. Deze gegevens zijn in overeenstemming met de resultaten van De Graaff (1989), die vond dat verpleegkundigen in staat waren de antwoorden op vragen met betrekking tot medisch probleemoplossen betrouwbaar te beoordelen. In het onderzoek van De Graaff werd gebruik gemaakt van een soortgelijke casustoets als in het onderhavige onderzoek. De antwoorden werden beoordeeld aan de hand van een beoordelingsmethode die nagenoeg overeenkomt met de korte antwoordsleutel. De door De Graaff gerapporteerde generaliseerbaarheidscoëfficiënten zijn echter hoger dan de coëfficiënten die in het onderhavige onderzoek werden gevonden. Dit zou het gevolg kunnen zijn van de experimentele werkwijze. In het onderzoek zijn vrijwilligers gehanteerd die een financiële vergoeding kregen voor hun activiteiten. Aangezien de behaalde toetsscore geen consequenties had voor de studievoortgang van de studenten, zou het kunnen zijn dat de studenten minder "serieus" de vragen hebben beantwoord. Daardoor zou het verschil in behaalde resultaten van studenten uit verschillende jaargroepen kunnen zijn afgenomen, hetgeen een lagere betrouwbaarheid tot gevolg had.

Een andere mogelijke verklaring zou kunnen zijn dat in het onderzoek gebruik werd gemaakt van casus, die gericht waren op éen stadium van het S.O.E.P.-schema terwijl de casus die De Graaff toepaste alle stadia omvatte. Door het gebruik van casus die slechts betrekking hebben op één stadium van het S.O.E.P.-schema bestaat de kans, dat de itemvariantie groter wordt, hetgeen bij een korte casustoets de totale toetsbetrouwbaarheid kan verlagen.

De invloed van structurering van het beoordelingsproces op de totale toetsbetrouwbaarheid is met name waameembaar bij korte toetsen. Indien de toetslengte wordt verlengd, worden de effecten kleiner en ontstaan slechts minimale verschillen tussen de beoordelingsmethoden. Om de totale toetsbetrouwbaarheid te vergroten blijkt het zinvoller te zijn het aantal casus in een toets te vermeerderen en elke casus slechts door één beoordelaar te laten nakijken dan de helft van het aantal casus in een toets op te nemen en deze door twee personen te laten beoordelen. Dit is in overeenstemming met eerder in de literatuur gerapporteerde resultaten (o.a. Swanson et al., 1989).

\subsubsection{Betrouwbaarheid van zak/slaag-beslissingen}

Toetsresultaten worden geregeld gebruikt om beslissingen te nemen omtrent de studievoortgang van studenten. Hierbij vormt de behaalde score op een toets een indicatie voor de mate waarin een persoon bijvoorbeeld vaardigheid in medisch probleemoplossen bezit. Uitgaande van de gegevens uit het pilot onderzoek, dat de gemiddelde score op de 
casustoets lager was naarmate de beoordelingsmethode meer was gestructureerd, werd verwacht dat de betrouwbaarheid van de genomen zak/slaag-beslissing per beoordelingsmethode en per cesuur zou verschillen. Tevens werd verondersteld dat het aantal studenten dat slaagt bij een bepaalde cesuur zou samenhangen met de gehanteerde beoordelingsmethode.

In het onderzoek werden beide verwachtingen bevestigd. Zo daalde het aantal geslaagden naarmate de beoordelingsmethode meer werd gestructureerd. De betrouwbaarheid van de genomen zak/slaag-beslissing bij een bepaalde cesuur varieerde eveneens sterk per beoordelingsmethode, afhankelijk van de hoogte van de cesuur en de gemiddelde score van de studenten.

Geconcludeerd wordt, dat een uitsluitend inhoudelijke fundering van de absolute norm niet in het gewenste effect hoeft te resulteren. Het is noodzakelijk de hoogte van de cesuur af te stemmen op de gehanteerde beoordelingsmethode. De vraag is echter in hoeverre een dergelijke werkwijze praktisch realiseerbaar is. In het onderzoek waren de huisartsen die verantwoordelijk waren voor de definitieve samenstelling van de beoordelingsmethoden niet in staat op inhoudelijke gronden tot een absolute norm te komen. Daarnaast blijkt het moeilijk om op voorhand de moeilijkheidsgraad van een toets te bepalen. Ook dit werd in het onderzoek bevestigd, aangezien de moeilijkheidsgraad van de acht casus varieerde, terwijl was geprobeerd acht even moeilijke casus te maken.

\subsubsection{Weging}

Vraagstelling 5: Welke invloed heeft positieve weging op de validiteit van de beoordelingsmethoden?

Veelal vergroot het aanbrengen van wegingsfactoren de face-validity van de beoordelingsmethode. De waardering voor een gedifferentieerde weging komt voornamelijk voort uit de behoefte om bepaalde aspecten hoger te kunnen waarderen dan andere aspecten. In het onderzoek is alleen gebruik gemaakt van positieve weging daar het niet mogelijk bleek verschillende vormen van weging op inhoudelijke gronden aan te brengen.

$\mathrm{Bij}$ positieve weging wordt in de waardering onderscheid gemaakt tussen essentiële en minder essentiële aspecten. Bij een dergelijk onderscheid wordt de kans kleiner dat een persoon die slechts triviale aspecten vermeldt eenzelfde beoordeling krijgt als een persoon die de essentie van de vraag goed heeft. Op grond hiervan werd voorafgaande aan het onderzoek verwacht dat door het aanbrengen van positieve wegingsfactoren de validiteit van de beoordelingsmethode zou worden vergroot.

In het onderzoek werden lage correlaties gevonden tussen de gewogen en de ongewogen scores. Dit duidde er op dat de rangordening van studenten op basis van de gewogen scores anders is dan op basis van de ongewogen scores. Uit de gemiddelde score van de jaargroepen blijkt, dat bij de gewogen scores de verschillen tussen jaargroepen groter zijn dan bij de ongewogen scores. Het bleek dat de eerste- en vierdejaars studenten gemiddeld een hogere score kregen bij de ongewogen scores, terwijl de zesdejaars met de ongewogen scores tot een lagere gemiddelde score kwamen. Uitgaande van de veronderstelling dat de casustoets tot doel had de vaardigheid in medisch probleemoplossen te meten en dat deze vaardigheid toeneemt naarmate een persoon meer medisch is geschoold, werden bovenstaande resultaten opgevat als een bevestiging van de verwachting dat positieve wegingsfactoren de validiteit vergroten. 
Uit het correlationeel onderzoek bleek, dat de correlaties tussen de ongewogen scores lager waren vergeleken met de correlaties tussen de gewogen scores. Dit zou het gevolg kunnen zijn van het feit dat bij de ongewogen scores minder essentiële antwoorden evenveel punten opleveren dan zeer essentiële antwoorden. Het feit komt duidelijk tot uitdrukking in de relatief lage correlatie tussen beide scores.

Op basis van bovenstaade gegevens kan worden geconcludeerd, dat het op inhoudelijke gronden aanbrengen van positieve weging de ware variantie ten goede komt en het onderscheid tussen personen met een verschillende vaardigheid in medisch probleemoplossen vergroot. Het lijkt dan ook zinvol om bij de constructie van beoordelingsmethoden positieve weging toe te passen. In hoeverre het ontbreken van negatieve weging ten koste gaat van de validiteit is op basis van de gegevens niet te beantwoorden. Uitgaande van de bevindingen bij de constructie van beoordelingsmethoden voor PMP's, lijkt een aparte berekening van een score voor foutieve antwoorden gewenst. Dit zal in een nader onderzoek moeten worden bestudeerd.

\subsubsection{Waardering van de beoordelingsmethoden}

Vraagstelling 6: Hoe worden de verschillende beoordelingsmethoden door de beoordelaars ervaren?

Vraagstelling 7: Hoe wordt de kwaliteit van de beoordelingsmethoden door de beoordelaars ervaren?

De waardering van de beoordelaars voor een beoordelingsmethode wordt door tal van factoren bepaald. Naast weging blijkt de mate van structurering de mening over de kwaliteit van een beoordelingsmethode te beïnvloeden. Zo blijken beoordelaars een behoefte te hebben aan een zekere mate van structurering. Voorts blijkt dat beoordelaars een sterk beteugeld beoordelingsproces niet prettig vinden (Cough, 1962; Goldberg, 1968; Wiggins, 1973; Nisbett \& Ross, 1980).

Uit het onderzoek blijkt, dat alle drie de groepen beoordelaars de uitgebreide criterialijst te gedetailleerd vonden. De huisartsen prefereerden de korte antwoordsleutel te prefereren, terwijl zowel de geneeskunde studenten als de economie studenten de korte antwoordsleutel en de ingedikte criterialijst het prettigst vonden.

Met betrekking tot de kwaliteit van de beoordelingsmethoden werd Verondersteld, dat de inhoudsdeskundige beoordelaars de korte antwoordsleutel het meest adequaat zouden vinden, terwijl de niet-inhoudsdeskundige beoordelaars de uitgebreide criterialijst zouden prefereren. De resultaten vormden echter een zeer beperkte bevestiging van de hypothesen. De huisartsen bleken zowel het vrije oordeel als de korte antwoordsleutel het meest adequaat te vinden. De geneeskunde studenten vonden daarentegen zowel de ingedikte als de uitgebreide criterialijst het meest geschikt. Tegen de verwachting in werd dus ook door deze groep beoordelaars een sterke mate van structurering wenselijk geacht. Zoals verwacht ging bij de economie studenten de voorkeur uit naar de uitgebreide criterialijst. Op basis van deze resultaten kan worden geconcludeerd, dat de gewenste mate van structurering mede wordt bepaald door de inhoudsdeskundigheid van de beoordelaars. Verder blijkt dat ook inhoudsdeskundige beoordelaars een zekere mate van inhoudelijke instructie op prijs stellen. 


\subsection{Conclusies}

Op basis van de onderzoeksresultaten is het niet mogelijk én beoordelingsmethode als het meest adequaat aan te wijzen. $\mathrm{Bij}$ de keuze van een beoordelingsmethode dient met verschillende aspecten rekening te worden gehouden. Indien met zeer inhoudsdeskundige beoordelaars wordt gewerkt, is uit oogpunt van betrouwbaarheid en satisfactie van de beoordelaars een minder sterk gedetailleerde beoordelingsmethode aan te raden, zoals het vrije cordeel en de korte antwoordsleutel. Leken hebben daarentegen meer structuur nodig, maar kunnen met vergaand gestructureerde beoordelingsmethoden tot acceptabele beoordelingen komen.

In het geval dat vanuit een norm georiënteerd perspectief wordt gewerkt, lijkt een minimale structurering voldoende. Bij een domein georiënteerd perspectief is het vanuit betrouwbaarheidsoverwegingen wenselijk het beoordelingsproces meer te structureren.

Indien bij het beoordelen een domeingeoriënteerd perspectief wordt gehanteerd, moet bij het vaststellen van de cesuur rekening worden gehouden met de gebruikte beoordelingsmethode. Naarmate de beoordelingsmethode meer is gestructureerd, zal de gekozen cesuur lager moeten komen te liggen dan bij een minder gestructureerde methode, uitgaande van hetzelfde kennisniveau.

De mate van detaillering wordt daamaast bepaald door het gebruikte design. Indien elke beoordelaar slechts een beperkt aantal vragen van de studenten beoordeelt, neemt de invloed van een lage interbeoordelaarsbetrouwbaarheid op de totale betrouwbaarheid af doordat de verschillen tussen beoordelaars worden weggemiddeld. Naarmate de toetslengte toeneemt, worden de verschillen in de totale betrouwbaarheid tussen de beoordelingsmethoden eveneens geringer. Het aanbrengen van op inhoudelijke gronden gekozen wegingsfactoren lijkt gewenst om de validiteit van de beoordelingen te vergroten. In hoeverre negatieve weging de validiteit ten goede komt is op basis van dit onderzoek niet vast te stellen.

Ook buiten het competentie-domein van medisch probleemoplossen, worden in het onderwijs open vraagvormen veelvuldig toegepast. Hoewel het onderzoek is uitgevoerd met behulp van een casustoets voor het meten van vaardigheid in medisch probleemoplossen, is het de vraag of de resultaten alleen voor dergelijke meetinstrumenten gelden.

Het kenmerkende van de gebruikte open vragen is, dat het van tevoren niet mogelijk was de gewenste antworden gedetailleerd te beschrijven. Soortgelijke vragen worden eveneens binnen het onderwijs in andere disciplines toegepast. Ondanks het feit dat soortgelijk onderzoek (nog) niet in andere disciplines is uitgevoerd, lijkt het gerechtvaardigd de in deze paragraaf getrokken conclusies te extrapoleren naar andere disciplines.

\subsection{Het verschil tussen experimenteel onderzoek en onderwijspraktijk}

De vraag dient te worden gesteld, in hoeverre de gegevens van dit onderzoek direct mogen worden vertaald naar de alledaagse praktijk. In het onderzoek is namelijk een aantal factoren onder controle gehouden, die in de dagelijkse praktijk van het onderwijs niet kunnen worden beheerst. In de literatuur beschreven onderzoek naar context effecten die kunnen optreden bij het beoordelen van schriftelijk materiaal heeft aangetoond, dat een verscheidenheid aan factoren het beoordelingsproces kan beïnvloeden. De meest bekende zijn de volgorde van aanbieden van de antwoorden aan de beoordelaar, de kwali- 
teit van het handschrift, het verwachtingspatroon van de beoordelaar en de fysieke aantrekkelijkheid van de beoordeelde (zie hoofdstuk 2). Dergelijke verstorende aspecten zijn in het onderzoek zo veel mogelijk geëlimineerd door de antwoorden, met weglating van naam en studienummer, over te typen en deze vervolgens in verschillende volgorde aan de beoordelaars aan te bieden. Hoewel kan worden verondersteld, dat het vermijden van context effecten niet tegen de gevonden resultaten kan pleiten, dient bij de interpretatie van de gegevens hiermee rekening te worden gehouden. Hierbij moet met name de winst die qua betrouwbaarheid kan worden geboekt door de antwoorden over te typen worden afgezet tegen de tijd die noodzakelijk is om de antwoorden te typen.

Een ander belangrijk verschil tussen het onderzoek en de onderwijspraktijk wordt geïntroduceerd door het gebruik van vrijwilligers. Zowel voor het beantwoorden van de vragen als voor het beoordelen is in het onderzoek gebruik gemaakt van vrijwilligers. Ondanks het feit dat de studenten die de vragen hebben beantwoord, wat betreft hun kennisniveau zijn vergeleken met de jaargroep, blijft de kans bestaan dat deze groep studenten afwijkt van de totale populatie studenten. Daamaast wisten de studenten al vanaf het begin dat de gegeven antwoorden geen invloed zouden hebben op hun studievoortgangsbeoordeling. Het is mogelijk dat de studenten als gevolg hiervan een andere antwoordstrategie hebben gehanteerd. Ook het feit dat de zesdejaars studenten de vragen thuis mochten beantwoorden, kan invloed hebben gehad op de kwaliteit van de gegeven antwoorden. Uitgaande van deze mogelijke vertroebelingen van de gevonden resultaten, lijkt het noodzakelijk een kleine kanttekening te plaatsen bij de validiteit van de casuistiek, aangezien die op basis van de gegeven antwoorden is onderzocht. Aan de andere kant dient te worden opgemerkt dat de gevonden resultaten overeenkomen met die van De Graaff (1989).

Naast vrijwilligers die de vragen hebben beantwoord, werd in het onderzoek gebruik gemaakt van vrijwillige beoordelaars. Een groot aantal docenten vindt het nakijken van examens één van de minst leuke kanten van hun beroep. Met name het nakijken van lange stukken tekst wordt geregeld als tijdrovend en vervelend ervaren. Aangezien in het onderzoek de beoordelaars zich vrijwillig hadden aangemeld, zou kunnen worden verondersteld dat deze groep meer gemotiveerd is dan de gemiddelde docent. Zowel wat betreft het beoordelen als wat betreft het meewerken aan onderzoek van onderwijs. Aan de andere kant zou de deelname aan het onderzoek voornamelijk kunnen zijn gestuurd door de financiële vergoeding die er tegenover stond. Dit laatste argument lijkt meer te kunnen opgaan voor de vierde jaars studenten geneeskunde en economie, dan voor de huisartsen.

In welke mate het werken met vrijwillige beoordelaars van invloed is geweest op de gevonden resultaten, is moeilijk vast te stellen. Het opzetten van een dergelijk onderzoek in de dagelijkse onderwijspraktijk lijkt hiervoor de enige oplossing.

\subsection{Suggesties voor de onderwijspraktijk}

Het gebruik van casustoetsen voor het meten van de vaardigheid in medisch probleemoplossen lijkt een toekomst te hebben (Swanson et al., 1989, Bordage, 1989, De Graaff, 1989). Eén van de praktische problemen die aan het gebruik van casustoetsen is verbonden, betreft de constructietijd. Dit geldt zowel voor de casus als voor de antwoordsleutel. Uiteraard kost de constructie van zeer gedetailleerde antwoordsleutels meer tijd dan die van minder gedetailleerde sleutels. Daar staat tegenover dat de betrouwbaarheid van de 
gegeven oordelen een samenspel is tussen de mate van structurering en de inhoudsdeskundigheid van de beoordelaar.

Bij de constructie van de casuïstiek en de antwoordsleutels zijn inhoudsdeskundigen onontbeerlijk. Maar geldt dat ook voor de beoordelaars? Kortom, is het mogelijk om de experts in te zetten bij de constructie, terwijl de beoordeling geschiedt met behulp van minder deskundige beoordelaars?

Vanuit het oogpunt van face validity en maatschappelijke acceptabiliteit lijkt het gebruik van niet-experts als beoordelaars ontoelaatbaar. De gegevens uit het onderzoek suggereren echter dat leken in staat zouden zijn tot betrouwbare oordelen te komen, mits het beoordelingsproces optimaal wordt gestructureerd.

Aangezien de tijd van experts beperkt is, dient in de praktijk tussen verschillende belangen een afweging te worden gemaakt. Allereerst moet rekening worden gehouden met het feit dat een voldoende aantal casus in een toets moet worden opgenomen om een voldoende toetsbetrouwbaarheid te kunnen bereiken. Bij het maken van een dergelijke afweging lijkt het zinvol om bijvoorbeeld stil te staan bij de klachten van geneeskunde studenten die hun co-schappen lopen. Een veel gehoorde klacht ten aanzien van de coschapperiode is bijvoorbeeld dat de artsen in het ziekenhuis geen tijd kunnen vrijmaken voor een meer persoonlijke begeleiding van de studenten (Warndorff \& Essed, 1991). Indien de artsen die belast zijn met het begeleiden van de studenten geen tijd zouden hoeven te besteden aan het nakijken van de antwoorden op schriftelijke tentamens, zou dit de kwaliteit van de begeleiding ten goede kunnen komen. Kortom, het lijkt zinnig de tijd die experts moeten besteden aan het nakijken van studieprestaties te beperken, zodat hun expertise kan worden gebruikt voor meer urgente zaken (casus-ontwikkeling, begeleiding), aangezien het beoordelen door minder inhoudsdeskundige personen kan geschieden (mits het beoordelingsproces voldoende is gestructureerd).

Door de huidige technische ontwikkelingen lijkt een derde mogelijkheid te worden geïntroduceerd: computergestuurde beoordelingen.

Uitgaande van het feit dat leken in staat zijn met behulp van uitgebreide beoordelingsinstructies tot betrouwbare oordelen te komen, lijkt de weg naar computergestuurde beoordeling geopend. Indien de computer voldoende is geïnstrueerd, kan deze op uiterst consequente wijze alle antwoorden van oordelen voorzien. Zowel de inzet van beoordelaars als de invloed van de subjectiviteit op de beoordelingen wordt hierdoor geminimaliseerd. Daamaast wordt de mogelijkheid geboden om op korte termijn een grote casusbank op te bouwen, die een representatieve afspiegeling kan zijn van de voorkomende problemen in het beroepspraktijk. Een dergelijke manier van toetsen lijkt veelbelovend, mede omdat het gebruik van computers de mogelijkheid biedt de studenten regelmatig een aantal casus aan te bieden, hetgeen de betrouwbaarheid van de uitspraken ten goede komt. De toepasbaarheid van dergelijke computertoetsen wordt vooralsnog beperkt door problemen met de taalherkenning.

\subsection{Suggesties voor verder onderzoek}

Naast bovenstaande conclusies en suggesties, blijft een aantal vragen nog onbeantwoord, die in de nabije toekomst nader onderzoek vergen. Allereerst is het de vraag in hoeverre bovenstaande trends eveneens in een praktijk-setting worden gevonden. Hoewel aan een dergelijk onderzoek veel praktische problemen kleven, is het gewenst om de generaliseer- 
baarheid van de gevonden resultaten naar de dagelijkse praktijk meer te kunnen onderbouwen. Dit geldt voor zowel medisch onderwijs als onderwijs in andere disciplines.

In het onderzoek bleek, dat leken in staat zijn met behulp van vergaand gestructureerde beoordelingsmethoden tot betrouwbare en valide oordelen te komen. De vraag die echter onbeantwoord blijft, is in hoeverre met een vergaande structurering de gevolgde redenering in een antwoord kan worden beoordeeld. Indien een student wordt beoordeeld op het al dan niet aanwezig zijn van bepaalde kenmerken in het antwoord, zou het kunnen zijn dat een student alle deelaspecten noemt zonder de juiste relaties tussen de aspecten te kunnen leggen. Indien bij een gestructureerde beoordelingsmethode hiermee geen rekening wordt gehouden, bestaat het gevaar dat de validiteit van de meting afneemt. In het onderzoek is met name gebruik gemaakt van gestructureerde methoden waarin slechts deelaspecten werden beschreven, zonder de relatie tussen deze aspecten. Dit werd gedaan omdat het doel van het onderzoek was een eerste indruk te krijgen van de invloed van structurering van beoordelingsmethoden op betrouwbaarheid en validiteit. Uitgaande van de resultaten van het onderzoek, dat een zekere mate van structurering wenselijk is, lijkt het raadzaam in nader onderzoek behalve aan de optimale mate van structurering van beoordelingsmethoden eveneens aandacht te besteden aan de vraag in hoeverre logische relaties tussen deelaspecten in een beoordelingsmethode kunnen worden opgenomen.

In het onderzoek is om praktische redenen alleen de invloed van positieve weging op de validiteit van de gestructureerde beoordelingsmethoden bestudeerd. Het toepassen van positieve weging heeft tot gevolg dat elk correct antwoord met punten wordt beloond, maar dat antwoorden die in de praktijk tot catastrofale gevolgen zouden leiden niet worden bestraft. De vraag is in hoeverre het toepassen van cen combinatie van positieve en negatieve weging de validiteit van de beoordelingsmethode beinvloedt.

Een ander probleem dat aandacht verdient is het probleem van de concurrente validiteit. In een aantal studies wordt een lage correlatie tussen twee instrumenten die iets anders beogen te meten als bevestiging voor de concurrente validiteit gezien. Bij een vaardigheid als medisch probleemoplossen is een dergelijke conclusie veelal moeilijk te trekken omdat onduidelijk is in hoeverre een hypothetisch construct als medisch probleemoplossen met aspecten als medische kennis en vaardigheden samenhangt. Een belangrijk deel van het cognitief psychologisch onderzoek naar medisch probleemoplossen is gericht op het verschil tussen de redeneringen van personen met verschillende medische expertise bij het behandelen van een klinisch probleem. Het lijkt dan ook gewenst om onderzoek te verrichten naar de samenhang tussen medische kennis, medische vaardigheden en medisch probleemoplossen. Indien de samenhang tussen deze drie aspecten bekend is, kunnen meer duidelijke uitspraken worden gedaan omtrent de validiteit van instrumenten voor het meten van vaardigheid in medisch probleemoplossen en kan bij de constructie van nieuwe meetinstrumenten met deze bevindingen rekening worden gehouden. 


\section{SAMENVATTING}

In de afgelopen dertig jaar is een groot scala aan instrumenten voor medisch probleemoplossen ontwikkeld. Deze instrumenten worden gekenmerkt door het gebruik van patientproblemen (casus). De kwaliteit van deze instrumenten wordt voor een belangrijk deel beperkt door het feit dat medisch probleemoplossen sterk inhoudsafhankelijk blijkt te zijn. In de recent ontwikkelde instrumenten wordt getracht aan dit inhoudsspecificiteitsprobleem tegemoet te komen door een groot aantal casus in een toets op te nemen. Dil kan worden bereikt door de vragen te beperken tot de essentiële aspecten (Bordage \& Page, 1987; De Graaff, 1989; Page et al., 1990).

Bij deze instrumenten worden geregeld varianten van de gestructureerde open vraag gehanteerd (Feletti \& Smith, 1986). De betrouwbaarheid van de beoordelingen vormt bij open vragen echter een probleem. Empirisch onderzoek heeft aangetoond dat de geringe overeenstemming tussen beoordelaars een belangrijke bron van onbetrouwbaarheid is. De mate waarin dergelijke beoordelaarseffecten optreden lijkt voor een belangrijk deel te worden beïnvloed door de kwaliteit van de gehanteerde beoordelingsmethode. Onderzoeken in het taalonderwijs laten bijvoorbeeld zien dat zowel een te sterke als te zwakke structurering van het beoordelingsproces onbetrouwbaarheid in de hand werkt. De precieze relatie tussen de mate van structurering en het optreden van beoordelaarseffecten is echter onduidelijk, evenals de rol die de inhoudsdeskundigheid van de beoordelaar hierin speelt.

In deze dissertatie wordt een experimenteel onderzoek beschreven waarin beide aspecten werden onderzocht. Daarnaast werd in het onderzoek aandacht besteed aan de invloed van (positieve) weging op validiteit en betrouwbaarheid van gegeven beoordelingen. Tevens werd de praktische bruikbaarheid van de beoordelingsmethoden geïnventariseerd.

Voor het onderzoek werden acht casus ontwikkeld, die medisch inhoudelijk waren gericht op de huisartspraktijk. Bij elke casus werden één tot drie korte antwoordvragen geformuleerd, die betrekking hadden op de essentie van het patiëntprobleem. De casus en bijbehorende vragen werden aan geneeskunde studenten uit verschillende jaargroepen ter beantwoording voorgelegd. Voor het beoordelen van de antwoorden werden per vraag vier beoordelingsmethoden ontwikkeld. Deze methoden varieerden van geen tot vergaande structurering wat betreft inhoudelijke richtlijnen. In volgorde van toenemende structurering waren dit: (1) het vrije oordeel, (2) de korte antwoordsleutel, (3) de ingedikte criterialijst en (4) de uitgebreide criterialijst. Bij de drie gestructureerde beoordelingsmethoden werden wegingsfactoren aangebracht om de invloed van positieve weging op betrouwbaarheid en validiteit te kunnen bestuderen.

Om inzicht te krijgen in de interactie tussen de mate van structurering en de inhoudsdeskundigheid van de beoordelaars, werden de antwoorden aan drie verschillende groepen beoordelaars voorgelegd. Deze beoordelaarsgroepen bestonden respectievelijk uit huisartsen, vierdejaars geneeskunde en vierdejaars economie studenten. De waardering van de beoordelaars voor de verschillende beoordelingsmethoden werd door middel van een vragenlijst onderzocht.

De theoretische validiteit van de casus werd onderzocht door de gemiddeld behaalde score 
door de drie jaargroepen met elkaar te vergelijken. Indien de gemiddelde score toenam naarmate de studenten meer medisch onderwijs hadden gevolgd, werd dit opgevat als een indicatie voor theoretische validiteit.

De validiteit van de beoordelingsmethoden werd in eerste instantie onderzocht door middel van een correlationeel onderzoek, waarbij de correlatie tussen de verschillende beoordelingsmethoden werd berekend. Tevens werd de validiteit van de beoordelingsmethoden bestudeerd aan de hand van een discriminant-analyse. Hierbij werden de studenten op basis van de behaalde score op de casustoets in een jaargroep geplaatst en werd deze voorspelde indeling vergeleken met de daadwerkelijke groepsindeling van de studenten. Het percentage juiste classificaties werd als maat voor de validiteit genomen; hoe hoger het percentage des te meer valide is de beoordelingsmethode.

Voor de betrouwbaarheidsanalyses werd gebruik gemaakt van de generaliseerbaarheidstheorie. Om de relatieve bijdrage van de beoordelaars, de casus, de studenten en de interactie tussen deze factoren op de totale variantie te schatten werd per beoordelingsmethode een generaliseerbaarheidsstudie (G-studie) uitgevoerd. In de G-studie werd per beoordelingsmethode en voor elke groep beoordelaars een volledig gekruist $\mathrm{p} \times \mathrm{i} \times \mathrm{j}$ design gehanteerd. Op basis van de G-studie werd een aantal D-studies verricht. In de eerste D-studie werd de interbeoordelaarsbetrouwbaarheid geschat. In de resterende Dstudies werd de invloed van het aantal casus en beoordelaars op de totale betrouwbaarheid geschat. Deze D-studies werden uitgevoerd vanuit een norm en een criterium georiënteerd perspectief, gebruikmakend van zowel een volledig gekruist $\mathrm{p} \times \mathrm{i} \times \mathrm{j}$-design als een genest p $x$ j:i-design. Ten slotte werd een $D$-studie uitgevoerd waarin de consequenties van de gehanteerde beoordelingsmethode op de betrouwbaarheid van de genomen zak/slaagbeslissing werd bestudeerd. Hiertoe werd bij elke beoordelingsmethode de betrouwbaarheid berekend bij een cesuur van $30 \%, 40 \%, 50 \%$ en $60 \%$.

De invloed van positieve weging werd bestudeerd door de gewogen scores te correleren met de ongewogen scores per beoordelingsmethode. Daarnaast werden de correlaties tussen de verschillende beoordelingsmethoden op basis van de ongewogen scores berekend. Deze resultaten werden vergeleken met de correlaties tussen de gewogen scores.

Voorafgaande aan het hoofdonderzoek werd een pilot-onderzoek uitgevoerd. Hierin werden de beoordelingsmethoden ontwikkeld en de wegingsfactoren empirisch bepaald. Tevens werd de validiteit van het onderzoeksmateriaal en de praktische uitvoerbaarheid van het onderzoeksdesign bestudeerd.

Nadat minimale veranderingen in het onderzoeksmateriaal waren aangebracht, werd op basis van het pilot-onderzoek besloten het hoofdonderzoek uit te voeren.

Overeenkomstig het pilot-onderzoek werd in het hoofdonderzoek gevonden dat de gemiddelde score op de casustoets toenam naarmate de studenten meer medisch onderwijs hadden gevolgd. Daarnaast nam bij elke jaargroep de gemiddelde score af naarmate de beoordelingsmethode meer was gestructureerd. Deze tendens was bij alle beoordelingsmethoden waameembaar onafhankelijk van de medische expertise van de beoordelaars.

Wat betreft de correlaties tussen de verschillende beoordelingsmethoden werd het volgende geconstateerd: bij elke beoordelaarsgroep was de correlatie tussen het vrije oordeel en de gestructureerde beoordelingsmethoden kleiner dan de correlatie tussen de 
gestructureerde beoordelingsmethoden onderling. $\mathrm{Bij}$ de economie studenten werden eveneens lagere correlaties gevonden tussen de korte antwoordsleutel en de twee meer gestructureerde beoordelingsmethoden. De correlatie tussen de ingedikte en de uitgebreide criterialijst varieerde bij de drie groepen beoordelaars tussen .75 (huisartsen) en .87 (geneeskunde studenten). Ook na de correctie voor attenuatie, uitgevoerd met de interbeoordelaarsbetrouwbaarheid, bleef hetzelfde beeld gehandhaafd.

De validiteit van de beoordelingsmethoden werd vervolgens bestudeerd aan de hand van een discriminant-analyse. Uit deze analyse kwamen geen duidelijke verschillen tussen de beoordelingsmethoden naar voren. Elke groep beoordelaars bereikte met elke beoordelingsmethode een percentage van juiste classificaties tussen $76 \%$ en $80 \%$.

Per beoordelingsmethode werd de correlatie berekend tussen de drie groepen beoordelaars. Bij het vrije oordeel werd een lage correlatie tussen de groepen beoordelaars gevonden. Deze correlatie nam toe naarmate de beoordelingsmethode meer was gestructureerd. Tevens bleken de correlaties tussen de economie studenten en de inhoudsdeskundige beoordelaars niet drastisch af te wijken van de correlaties tussen de geneeskunde studenten en de huisartsen indien een minimale structurering aanwezig was.

Uit de resultaten van de G-studie bleek dat door elke beoordelaarsgroep met het vrije oordeel, in vergelijking met de gestructureerde beoordelingsmethoden, het meeste onderscheid tussen personen werd aangebracht en de verschillen in de rangordening van de studenten door de beoordelaars groter was. Daamaast werd voor de algemene error variantie de grootste component gevonden. Voorts bleek dat met de gestructureerde beoordelingsmethoden grotere verschillen in de moeilijkheidsgraad van de casus werden geconstateerd. Bij de gestructureerde beoordelingsmethoden was de inconsistentie van personen over casus (inhoudsspecificiteit) eveneens beduidend groter dan bij het vrije oordeel.

Opvallend was dat bij alle drie de groepen beoordelaars de algemene error variantie bij het vrije oordeel toenam ten koste van de pi-component (de inconsistentie van personen over casus), terwijl bij de gestructureerde beoordelingsmethoden deze afnam ten gunste van de pi-component.

Met betrekking tot de interbeoordelaarsbetrouwbaarheid werd een onverwachte trend gevonden. Bij de huisartsen nam de interbeoordelaarsbetrouwbaarheid toe naarmate de beoordelingsmethode meer was gestructureerd. Bij de geneeskunde en economie studenten was de overeenstemming het grootst bij respectievelijk de ingedikte en uitgebreide criterialijst. Deze resultaten waren niet conform de verwachting dat de overeenstemming tussen de inhoudsdeskundige beoordelaars het grootst zou zijn met de korte antwoordsleutel en de ingedikte criterialijst. De verwachting dat de interbeoordelaarsbetrouwbaarheid bij de economie studenten zou toenemen naarmate de beoordelingsmethode meer was gestructureerd, werd niet bevestigd.

De totale betrouwbaarheid is in een viertal D-studies bestudeerd. Zoals op basis van de grote ware variantie en de lage pi-component bij het vrije oordeel kon worden voorspeld, werd bij deze beoordelingsmethode de hoogste totale betrouwbaarheid gevonden ongeacht de expertise van de beoordelaars en het gehanteerde design. Bij het geneste design waren de verschillen tussen het vrije oordeel en de gestructureerde methoden groter dan bij het gekruiste design. Dit werd veroorzaakt door de lagere interbeoordelaarsbetrouwbaarheid 
bij het vrije oordeel.

Tussen de drie gestructureerde beoordelingsmethoden werden slechts minimale verschillen gevonden in de hoogte van de totale betrouwbaarheid, ongeacht de expertise van de beoordelaars. Deze resultaten vormden dus geen bevestiging van de hypothese dat bij de economie studenten de totale betrouwbaarheid zou toenemen naarmate de beoordelingsmethode meer was gestructureerd. Op basis van de resultaten werd eveneens de hypothese verworpen dat zowel de geneeskunde studenten als de huisartsen met de korte antwoordsleutel en de ingedikte criterialijst tot de hoogste totale betrouwbaarheid zouden komen.

Naast de invloed van structurering van beoordelingsmethoden op de interbeoordelaars- en de totale betrouwbaarheid waren de consequenties van de gehanteerde beoordelingsmethode op de betrouwbaarheid van zak/slaag-beslissingen onderwerp van studie. Als gevolg van de verschillen in de gemiddelde score per beoordelingsmethode varieerde de betrouwbaarheid van de genomen zak/slaag-beslissing bij de verschillende cesuren sterk per beoordelingsmethode. Geconcludeerd werd dat bij de bepaling van de zak/slaag-grens rekening moet worden gehouden met de mate van structurering van de beoordelingsmethode.

Uit de vergelijking tussen de gewogen en de ongewogen scores bleek dat bij de ongewogen scores de eerste- en vierdejaars studenten gemiddeld beduidend hogere waarderingen behaalden dan bij de gewogen scores. Bij de zesdejaars studenten was het omgekeerde waarneembaar. Deze resultaten bevestigden de hypothese dat het aanbrengen van positieve weging de validiteit van de beoordelingsmethoden vergroot.

In het correlationeel onderzoek werden lage correlaties tussen de gewogen en de ongewogen scores voor elke beoordelingsmethode gevonden. Daamaast bleek dat de correlaties tussen de gestructureerde beoordelingsmethoden bij de ongewogen scores lager waren dan bij de gewogen scores. Op basis van deze resultaten werd geconcludeerd dat het aanbrengen van op inhoudelijke gronden aangebrachte positieve wegingsfactoren de inhoudsvaliditeit van de beoordelingsmethoden vergroot.

Wat betreft de waardering van de beoordelaars voor de verschillende beoordelingsmethoden kwam een zeer gedifferentieerd beeld naar voren. Het merendeel van de huisartsen vond het vrije oordeel en de korte antwoordsleutel het meest adequaat. De geneeskunde studenten waren daarentegen van mening dat met de ingedikte en de uitgebreide criterialijst de meest adequate beoordelingen konden worden gegeven. De meeste economie studenten waren van mening dat met de uitgebreide criterialijst de antwoorden van de studenten het meest adequaat beoordeeld konden worden.

Op grond van de onderzoeksresultaten kon geen uniform advies worden gegeven omtrent de meest adequate mate van structurering. Uit de resultaten bleek echter wel dat het vrije oordeel tot betere resultaten leidde dan voorafgaande aan het onderzoek werd verwacht, en dat door een minimale structurering de verschillen tussen leken en inhoudsdeskundige beoordelaars werden teruggedrongen, evenals de verschillen tussen inhoudsdeskundigen onderling. Tevens toonden de resultaten dat leken met een voldoende inhoudelijke instructie in staat zijn een moeilijk aspect als medisch probleemoplossen te beoordelen.

Concluderend kan worden gesteld dat bij de keuze van een beoordelingsmethode met verschillende aspecten rekening dient te worden gehouden, zoals de deskundigheid van de beoordelaars, de verdeling van de antwoorden over de beoordelaars en de lengte van de 
toets.

In het onderzoek is een aantal factoren onder controle gehouden, die in de dagelijkse praktijk van het onderwijs niet kunnen worden beheerst. Welke invloed deze experimentele aanpak kan hebben voor de generaliseerbaarheid van de gegevens naar de onderwijspraktijk, wordt in het laatste hoofdstuk beschreven. Daarnaast wordt in dit hoofdstuk een aantal suggesties voor verder onderzoek gedaan. 


\section{SUMMARY}

Over the past three decades a great number of written clinical simulations have been developed for the purpose of testing problem-solving skills of medical students. Most studies on those instruments, however, had to report poor psychometric characteristics. Especially, the variability in examinee performance from case to case appears to cause problems. More recently developed instruments include a large number of simulations to overcome this problem of content specificity. Frequently these tests use some kind of modified essay question. Such open-answer type questions introduce a hazard to the reliability of the ratings. In many studies low agreement between raters is found. Even among expert-raters variation in ratings appears to be high. A number of studies have suggested that the lack of agreement between raters is due to the quality of the answerkey. The results showed that too much structure as well as too little structure in the answer-key could induce disagreement. Two important questions, however, remain unanswered. In the first place: to what extent should the answer-key be structured? and, in the second place, what is the relationship between the expertise of the rater and the extent of structure in an answer key?

This thesis discusses an experiment in which the influence of the structuring of the answer-key and the expertise of raters on reliability was studied. The impact of positive weighting on reliability and validity was also investigated. At the same time, the validity of the cases and the practical usefulness of several answer-keys was examined.

In accordance with suggestions by Norman et al. (1987) a test consisting of eight short cases related to patient management problems was developed. The cases consisted of patient problems encountered in an average family physician practice and included both physical and psychological complaints. Each case was followed by one to three restricted response questions (a total of 11) which focussed on the quintessence of the problem. The cases were divided into four groups according to the stages of the S.O.A.P. scheme, resulting in two separate cases per stage.

The cases were administered to 98 medical students from three classes (18 first year students, 40 fourth year students and 40 sixth year students). For each question four different scoring methods were developed varying in the extent of structure. With increasing structure the scoring methods were: (1) global judgement method, (2) short answer key, (3) global checklist and (4) elaborated checklist. Positive weights were assigned to the categories in the three structured scoring methods to investigate the influence of weights on resulting scores.

The answers were scored by three groups of raters varying in medical expertise. These groups consisted of 16 general practitioners, 16 fourth year medical students and 16 fourth year economical students (laymen with respect to the medical domain). A questionnaire was constructed to investigate the appraisal of the scoring methods.

The study was conducted in two phases. First the construction of the test materials and the feasibility of the design of the study were tried out in a pilot-study. This resulted in a few alterations and the adjustment of the relative weight factors. Next the main study was carried out. 
In a first analysis the discriminant validity of the cases was studied by comparing the mean scores of the three classes of medical students. The mean scores on the test appeared to increase significantly as the students had followed more years medical training. Also, the mean scores decreased as the scoring method was more structured. This tendency was found for the four scoring methods and the three groups of raters. The increase in mean scores as the students had more medical education was interpreted as an affirmation of validity.

To investigate the validity of the scoring methods correlations between the four scoring methods and between the three groups of raters were carried out. and discriminant function analyses were carried out. Discriminant function analyses was also carried out to investigate validity of the scoring methods. The number of correct classifications was taken as measure of validity; the more students correctly classified the more valid the scoring method.

The correlations between the global judgement method and the three structured scoring methods were lower than the correlations between the three structured scoring methods, for all three groups of raters. For the layman raters the correlations between the short answer key and the other structured scoring methods were also lower than the correlations between the global checklist and the elaborated checklist. The correlation between the global checklist and the elaborated checklist varied from .75 (general practitioners) to .87 (medical students).

Correlations between the three groups of raters were estimated per scoring method. Low correlations were found for the global judgement method. Correlations increased as the scoring method was more structured. The correlations between the laymen raters and the general practitioners did not differ from the correlations between the medical students and the general practitioners, if the scoring method was minimally structured. These findings suggest that laymen raters are not inferior to experts.

The discriminant function analysis did reveal no clear differences between the four scoring methods. The percentage of correct classifications ranged from $76 \%$ to $80 \%$ for the three groups of raters. Therefore it was concluded that from this analysis the validity of all four methods was acceptable, and no method was superior.

Generalizability analyses were carried out in order to investigate the relative contribution of the facets students (p), cases (i) and raters (j), and the interactions between these facets on the total variance. Within each group of raters a totally crossed $\mathrm{p} \times \mathrm{i} \times \mathrm{j}$-design was available for each scoring method.

The estimated variance component associated with the person facet as well as the $\mathrm{p} \mathrm{x} j$ interaction term was the highest for the global judgement method. The overall error component was also larger for the global judgement method compared to the structured scoring methods. For the structured scoring methods larger differences between cases were found. The inconsistency of persons over cases (content specificity problem) was considerably higher for the structured scoring methods compared to the global judgement method. A tendency was found that the overall error component for the global judgement method increased at the cost of the $\mathrm{p} x \mathrm{i}$-component for the global judgement method. On 
the contrary, the overall error component decreased in favor of the $\mathrm{p} x \mathrm{i}$-component for the structured scoring methods.

For the economical students it was expected that the inter rater reliability should increase as the scoring method was more structured. For the medical students as well as the general practitioners the highest agreement between was expected to be found for the short answer key and the global checklist. The results showed another picture. For the economical student highest inter rater reliability was found for the elaborated checklist. There was no systematic tendency that the agreement increased as a result of structuring the scoring methods. The agreement between medical students was highest for the global checklist. In contrast with the expectations, the agreement between general practitioners increased as the scoring method was more structured.

The results of the G-study were used in several Decision-studies (D-study) to estimate a number of reliability-coefficients. In one D-study the inter rater reliability was estimated. In the other D-studies the impact of the number of cases and the number of raters on reproducibility of scores was investigated. Finally, a D-study was carried out to study the reliability of pass/fail decisions, using cut-off scores of $30 \%, 40 \%, 50 \%$ and $60 \%$. The D-studies were conducted within a norm referenced as well as a criterion referenced approach, with a totally crossed and a nested design.

Highest overall reproducibility was found for the global judgement method. This was primarily caused by the high p-component and the low $\mathrm{p} \times \mathrm{i}$-component. Between the structured scoring methods only small differences were found. These findings were more extreme in a nested design due to the low inter rater reliability for the global judgement method. These results were not in agreement with the hypothesis that the highest overall reproducibility should be found for the short answer key and the global checklist for the medical students as well as the general practitioners. The hypothesis that for the layman raters the reproducibility should increase as the scoring method was more structured, was also not confirmed.

The influence of structuring on the reliability of pass/fail-decisions was also investigated with a D-study. The reliability of pass/fail-decisions substantially varied for the different passing scores and the four scoring methods, due to the differences in mean scores. It was concluded that passing scores should be related to the scoring method used.

To investigate the impact of weighting on the ranking of students, correlations between weighted and unweighted scores were calculated. Also, the correlations between the scoring methods based on weighted composite scores were compared with the correlations based on unweighted composite scores.

This comparison showed that the mean scores for the first and the fourth year students were higher for the unweighted than for the weighted scores. In contrast, the mean score for the sixth year students was lower for the unweighted scored compared to the weighted scores. These results confirmed the hypothesis that positive weighting increases the (discriminant) validity of scoring methods.

Correlation between weighted and unweighted composite scores was low. Besides, 
correlations between the structured scoring methods were higher for the weighted than for the unweighted scores. It was therefore concluded that positive weighting increases the construct validity of scoring methods.

Finally the appreciation for the different scoring methods was investigated by means of a questionnaire. Appreciation for the scoring methods varied with the expertise of the raters. The majority of general practitioners preferred the global judgement method and the short answer key most. The medical students preferred the global checklist and the elaborated checklist. The elaborated checklist was also preferred above the other scoring methods by the layman raters.

On the basis of this study it is not possible to recommend a single best scoring method. The global judgment method was more appropriate than expected. It was found that even a minimally structured scoring method can minimalize the differences between raters. Likewise, the results showed that laymen are capable to produce reliable and valid ratings of medical problem solving, provided they are equipped with appropriate information.

This leads to the conclusion that several aspects have to be taken into account when making a choice for a scoring method in a specific situation. Among them the test length, the availability of expert raters, time needed for the construction of answer keys and the distribution of the answers to the raters.

In an experimental study several factors can be controlled, which is not possible in a normal educational setting. As a consequence, the generalizability of the results for the educational practice should be studied. In the last chapter of the thesis a number of suggestions for further study are proposed. 


\section{LITERATUUR}

Adams, G.R. \& Lavoie, J.C. (1974) Effect of student sex, conduct, and facial attractiveness on teacher expectancy. Education, 95, 76-83.

Aloia, G.F., Maxwell, J.A. \& Aloia, S.D. (1981) Influence of a child's race and EMR label on initial impressions of regular classroom teachers. American Joumal of Mental Deficiency, 85, 619-623.

Asendorf, J.A. \& Wallbott, H.G. (1979) Maße der Beobachterübereinstimmung: ein systematischer Vergleich. Zeitschrift für Sozialpsychologie, 10, 243-252.

Barrows, H.S. \& Bennet, K. (1972) The diagnostic (problem solving) skill of the neurologist: experimental studies and their implications for neurological training. Archives of Neurology, 26, 273-277.

Barrows, H.S., Feightner, J.W., Neufeld, V.R. \& Norman, G.R. (1978) An analysis of the clinical method of medical students and physicians. Hamilton, Ontario, Canada: McMaster University.

Barrows, H., Williams, R. \& Moy, R. (1987) A comprehensive performance-based assessment of fourth-year students' clinical skills. Journal of Medical Education, 62, 805-809.

Berkel, H.J.M. van (1984) De diagnose van toetsvragen. Amsterdam: Thesis, Centrum voor Onderzoek van het Wetenschappelijk Onderwijs.

Berner, E.S., Bligh, T.J. \& Guerin, R.O. (1977) An indication for a process dimension in medical problem solving. Medical Education, 11, 324.

Berner, E.S., Hamilton, L.A. \& Best, W.R. (1974) A new approach to evaluating problem solving in medical students. Journal of Medical Education, 49, 666-672.

Birnbaum, A. (1968) Some latent trait models and their use in examinee's ability. In F.M. Lord \& M.R. Novick, Statistical theories of mental test scores. Massachusetts: Addison-Wesley.

Bimbaum, A. (1969) Statistical theory for logistic mental test models with a prior distribution of ability. Journal of Mathematical Psychology, 6, 258-276.

Bligh, T.J. (1980) Written simulation scoring: comparison of nine systems. PhD dissertation. Urbana-Champaign, IL, University of Illinois.

Bock, R.D. (1972) Estimating item parameters and latent ability when responses are scored in two or more nominal categories. Psychometrika, 37, 29-51.

Bordage, G. \& Page, G. (1987) An altemative approach to PMP's: the "key features" concept. Proceedings of Further Developments in assessing clinical competence, 5975.

Brennan, R.L. (1983) Elements of generalizability theory. Iowa: American College Testing Program.

Brennan, R.L. \& Kane, M.T. (1979) An index of dependability for mastery tests. Journal of Educational Measurement, 14, 277-189.

Briggs, D. (1970) The influence of handwriting on assessment. Educational Research, 13, 50-55.

Carlson, R.E. (1970) Effects of applicant sample on ratings of valid information in an employment setting. Joumal of Applied Psychology, 54, 217-222. 
Case, S.M. (1981) A new examination for the evaluation of diagnostic problem-solving. Proceedings of the $20^{h}$ Annual Conference on Research in Medical Education, 8085.

Cate, R.S. ten, Duyn, van \& Versfelt, W.A. (1981) The modified essay question as a method for assessment. In J.C.M. Metz, J. Moll \& H.J. Walton (eds.) Examination in medical education. A necessary evil? Utrecht: Wetenschappelijke uitgeverij Bunge.

Chase, C.I. (1968) The impact of some obvious variables on essay test scores. Journal of Educational Measurement, 3, 315-318.

Chase, C.I. (1979) The impact of achievement expectations and handwriting quality on scoring essay tests. Journal of Educational Measurement, 6, 1, 39-42.

Chase, C.I. (1983) Essay test scores and reading difficulty. Journal of Educational Measurement, 20, 293-297.

Chase, C.I. (1986) Essay test scoring: interaction of relevant variables. Journal of Educational Measurement, 23, 1, 33-41.

Clifton, R.A. (1981-1982) The effect of student ethnicity and sex on the expectation of teachers. Interchange on Educational Policy, 21, 31-38.

Coffman, W.E. (1971) Essay examinations. Thomdike, R.J. (Ed.) Educational Measurement. Washington: $A C E, 271-302$.

Cooper, H., Baron, R. \& Lowe, C. (1975) The importance of race and social class information in the formation of expectations about academic performance. Journal of Educational Psychology, 67, 312-319.

Crick, J.E. \& Brennan, R.L. (1982) Manual for GENOVA: A generalized analysis of variance system. Iowa: American College Testing Program.

Cronbach, L.J. (1964) Educational Psychology. New York: Harper \& Row.

Cronbach, L.J., Gleser, G.C., Nanda, H. \& Rajaratnam, N. (1972) The dependability of behavioral measurements: Generalizability for scores and profiles. New York: John Wiley and Sons, Inc.

Cronbach, L.J. \& Meehl, P.E. (1955) Construct validity in psychological tests. Psychological Bulletin, 52, 281-302.

Crowburst, M. (1980) Systematic complexity and teachers' quality ratings of narrations and arguments. Research in the Teaching of English, 14, 223-232.

Daly, J.A. \& Dickson-Markman, F. (1982) Contrast effects in evaluating essays. Journal of Educational Measurement, 9, 4, 309-316.

Dash, A.S. (1975) A study of the expectancy bias and the suggestion bias of teachers. Journal of Psychological Researches, 19, 17-19.

Diederich, P.E., French, S.W. \& Carlton, S.T. (1961) Judgements of writing ability. (Research Bulletin) Princeton: Educational Testing Service.

Dion, K. (1972) Physical attractiveness and evaluation of children's transgressions. Joumal of Personality and Social Psychology, 24, 207-213.

Divesta, F. (1961) Contrast effects in assessment decisions. Journal of Experimental Psychology, 62, 535-544.

Donnally, M.B. (1976) Measuring performance on patient management problems. Proceedings of the $15^{\text {th }}$ Annual Conference on Research in Medical Education, 161166. 
Donnelly, M.B., Gallagher, R.E., Hess, J.W. \& Hogan, M.J. (1974) The dimensionality of measures derived from complex medical simulations. Proceedings of the $13^{\text {th }}$ Annual Conference on Research in Medical Education, 14-19.

Drenth, J.D. (1984) Inleiding in de testtheorie. Deventer: Van Loghum Slaterus.

Ebel, R.L. \& Frisbie, D.A. (1986) Essentials of educational measurement. New Jersey: Prentice Hall Inc.

Elstein, A.S., Shulman, L.S. \& Sprafka, S.A. (1978) Medical problem solving. An analysis of clinical reasoning. Cambridge, Massachusetts en London: Harvard University Press.

Feightner, J.W. (1985) Patient management problems. In V.R. Neufeld \& G.R. Norman (eds.) Assessing Clinical Competence. New York: Springer Publishing Company, hoofdstuk 9, 183-200.

Feletti, G.I. (1980) Reliability and validity studies on modified essay questions. Medical Education, 55, 933-941.

Feletti, G.I. \& Smith, K.M. (1986) Modified essay questions: are they worth the effort? Medical Education, 20, 126-132.

Freedman, S.W. (1979) How characteristics of student essays influence teachers' evaluations. Journal of Educational Psychology, 71, 328-338.

Geerligs, T. (1991) Scriptiebeoordeling. Onderzoek van Onderwijs: Vakblad voor docenten in het hoger onderwijs, 3, 35-38.

Gerritsma, J.G.M. \& Smal, J.A. (1974) Grensverschuivingen in het medisch onderwijs. Utrecht: Oosthoek, Scheltema \& Holkema.

Gerritsma, J.G.M. \& Smal, J.A. (1982) De werkwijze van huisarts en internist. Een vergelijkend onderzoek met behulp van een interactieve patiëntensimulatie. Dissertatie Utrecht, Utrecht: Wetenschappelijke uitgeverij Bunge.

Ghiselli, E. (1964) Theory of psychological measurement. New York: McGraw-Hill.

Goldberg, P. (1968) Are woman prejudiced against woman? Trans-action, 28-30.

Goran, M.J., Williamson, W.J. \& Gonella, J.S. (1973) The validity of patient management problems. Journal of Medical Education, 48, 171-177.

Graaff, E. de (1988) Simulation of initial medical problem-solving: A test for the assessment of midical problem-solving. Medical Teacher, 10, 1 49-55.

Graaff, E. de (1989) Simulation of initial medical problem-solving. Haarlem: Uitgeverij Thesis.

Graaff, E. de \& Peeters, T. (1989) Toetsen op basis van casuistiek. Onderzoek van Onderwijs: Vakblad voor docenten in het hoger onderwijs, 18, 2, 29-32.

Graaff, E. de, Post, G.J. \& Drop, M.J. (1987) Validation of a new measure of clinical problem-solving. Medical Education, 21, 213-218.

Grobe, C. (1981) Syntactic maturity, mechanics and vocabulary as predictors of quality ratings. Research in the Teaching of English, 15, 75-85.

Groot, A.D. de (1965) Methodologie. Grondslagen van onderzoek en denken in de gedragswetenschappen. Den Haag: Mouton.

Grosse, M. (1981) Patient Management Problems: Review evaluation and recommandations. Philadelphia: National Board of Medical Examiners.

Gruyter, D.N.M. de \& Kamp, L.J.Th. van der (1984) Statistical models in psychological and educational setting. Lisse: Swetz \& Zeitlinger. 
Guttman, L. (1950) The basis for scalogram analysis. In S.A. Stouffer, L. Guttman, E.A. Suchman, P.F. Lazarsfeld, S.A. Star, J.A. Clausen, (eds.) Measurement and prediction, Vol. IV, Princeton, N.J.: Princeton University Press.

Hakel, M., Ohnesorge, J.P. \& Dunnette, M.D. (1970) Interviewer evaluations of job applicants"' resumes as a function of the qualification of the immediately preceding applicant. Journal of Applied Psychology, 54, 27-30.

Hales, .W. \& Tokar, E. (1975) The effect of the quality of preceding responses on the grades assigned to subsequent responses to an essay question. Journal of Educational Measurement, 12, 2, 115-117.

Hall, C.G.W. \& Daglish, N.D. (1982) Length and quality: An exploratory study of inter marker reliability. Assessment in Higher Education, 7, 186-191.

Hambleton, R.K. \& Cook, L.L. (1977) Latent trait models and their use in the analysis of educational test data. Joumal of Educational Measurement, 4, 2, 75-96.

Hambleton, R.K. \& Swaminathan, H. (1985) Item-response theory: Principles and applications. Boston: Kluwer Publishing.

Harden, R.M. (1983) Preparation and presentation of patient-management problems (PMP's). Medical Education, 17, 256-276.

Harris, W.H. (1977) Teacher response to student writing: A study of the response patterns of high school english teachers to determine the basis for teacher judgement of student writing. Reasearch in the Teaching of Enlish, 11, 175-185.

Hartmann, D.P. (1979) Considerations in the choice of interobserver reliability estimates. Journal of Applied Behavior Analysis, 10, 103-116.

Helson, H. (1947) Adaption-level as a frame of reference for prediction of psychophysical data. American Journal of Psychology, 60, 1-29.

Helson, H. (1964) Adaption-level theory. New York: Harper \& Row.

Hofstee, W.K.B. (1980) De empirische discussie. Theorie van het sociaal-wetenschappelijk onderzoek. Meppel: Boom.

Hofstee, W.K.B. (1983) Beoordelingen van subsidie-aanvragen voor onderwijsresearch: een psychometrische evaluatie. Tijdschrift voor Onderwijsresearch, 8, 273-283.

Hofstee, W.K.B. (1985) Liever klinisch? Grenzen aan het objectiviteitsbeginsel bij beoordeling en selectie. Nederlands Tijdschrift voor de Psychologie, 40, 459-473.

Holmes, D. \& Berkowitz, L. (1961) Some contrast effects in social perceptions. Journal of Abnormal and Social Psychology, 62, 150-152.

House, A.E., House, B.J. \& Vampbell, M.B. (1981) Measures of interobserver agreement: Calculation formulas on distribution effects. Journal of Behavioral Measurement, 3 , $37-57$.

Hout, B. (1990) The literature of direct writing measurement: Major concerns and prevailing trends. Review of Educational Research, 60, 237-263.

Hovland, C., Harvey, O. \& Sherof, M. (1957) Assimilation and contrast effects in reactions to communication and attitude change. Journal of Abnormal and Social Psychology, $55,244-252$.

Hubbard, J.P. (1978) Measuring medical education: The tests and the experience of the National Board of Medical Examinations. Philadelphia: Lee \& Febiger.

Hubbard, J.P., Levitt, E.J. \& Schumacher, C.F. (1965) An objective evaluation of clinical competence: New techniques used by the National Board of Medical Examinations. English Journal of Medicine, 272, 1321-1328. 
Hughes, D.C. \& Keeling, B. (1984) The use of model essays to reduce context effects in essay scoring. Joumal of Educational Measurement, 21, 3, 277-281.

Hughes, D.C., Keeling, B. \& Tuck, B. (1980) The influence of context position and scoring method on essay scoring. Journal of Educational Measurement, 17,2, 131-135.

Hughes, D.C., Keeling, B. \& Tuck, B.F. (1983) Effects of achievement expectations and handwriting quality on scoring essays. Journal of Educational Measurement, 20, 1, 65-70.

Imbos, Tj. (1989) Het gebruik van einddoeltoetsen bij aanvang van de studie. Gulpen: Drukkerij Alberts/Druko.

James, H.W. (1927) The effect of handwriting upon grading. The English Journal, 16, 180 1185.

Jansweijer, W.N.H., Elshout, J.J. \& Wielinga, B.J. (1985) Het leren van de beginnende probleemoplosser. In J.G.L.C. Lodewijcks \& P.R.J. Simons (eds.) Zelfstandig leren, bijdrage tot de Onderwijsresearchdagen 1984. Lisse: Swets \& Zeitlinger.

Jong, T. de (1981) Correctievoorschriften voor de beoordeling van open vragenen interbeoordelaarsbetrouwbaarheid. Tijdschrifi voor Onderwijsresearch, 6, 217-229.

Juul, D.H., Noe, M.J. \& Nerenberg, R.L. (1974) A factor analytic study of branching patient management problems. Paper at the annual meeting of the National Council of Measurement in Education, New York City, april 1974.

Kenrick, D.T. \& Gutierres, S.E. (1980) Contrast effects and judgements of physical attractiveness: When beauty becomes a social problem. Joumal of Personality and and Social Psychology, 38, 131-140.

Kleinmuntz, B. (1984) The scientific study of clinical judgement in psychology and medicine. Clinical Psychological Review, 4, 111-126.

Knox, J.D.E. (1975) Modified essay question. University of Dundee: Association for the study of Medical Education, booklet no. 5 .

Koppelman, M.D. (1975) The contrast effect in the selection interview. British Joumal of Educational Psychology, 45, 333-336.

Landy, F.J. \& Bates, F. (1973) Another look at contrast effects in the employment interview. Journal of Applied Psychology, 58, 141-144.

Landy, D. \& Sigall, G. (1974) Beauty is talent. Journal of Personality and Social Psychology, 29, 299-304.

Levine, H.G. (1967) An analysis of construct validity of two simulation techniques. Chicago: University of Illinois.

Levine, H.G. \& Noak, J.R. (1968) The evaluation of complex educational outcomes. Washington, D.C.: U.S. Departement of Health, Education and Welfare.

Lisdonk, E.H. van \& Kartodirdjo, R.R. (1980) De gestructureerde open vraag. Nijmegen: Universitair Huisartseninstituut.

Lord, F.M. (1974) Estimation of latent ability and item parameters when there are omitted responses. Psychometrika, 39, 247-264.

Lord, F.M. \& Nvick, M.R. (1968) Statistical theories of mental test scores. Mento Park, California: Addison-Wesley.

Markham, L.R. (1976) Influences of handwriting quality on teacher evaluation of written work. American Educational Research Journal, 13, 4, 277-283.

Marshall, J.C. \& Powers, J.C. (1969) Writing neatness, composition errors, and essay grades. Journal of Educational Measurement, 6, 97-101.

Marshall, J. (1977) Assessment of problem-solving ability. Medical Education, 11, 329-334. 
Martin, I.C. (1975) Emperical examination of the sequential management problem for measuring clinical competence. Proceedings of the 14th Annual Conference on Research in Medical Education, Washington, D.C., 83-88.

Maxwell, A.E. (1977) Coefficients of agreement between observers and their interpretation. British Journal of Behavior, 30, 79-83.

Mazzuca, S.A. \& Cohen, S.J. (1982) Scoring patient management problems: External validation of expert consensus. Evaluation and the Health Professions, 5, 20, 210217.

McCarthy, W.H. (1966) An assessment of the influence of cuing items on objective examinations. Journal of Medical Educarion, 41, 263-266.

McGuire, C. (1963) A process approach to the construction and analysis of medical examinations. Journal of Medical Education, 38, 556-563.

McGuire, C.H. (1967) A summary of the evidence regarding the technical characteristics of parient management problems to AAOS Examinations Committee. University of Inlinois.

McGuire, C. (1976) Simulation technique in the teaching and testing of problem solving skills. Journal of Research in Science Teaching, 13, 2, 89.

McGuire, C.H. \& Babbott, D. (1967) Simulation technique in the measurement of problem solving skills. Educational and Psychological Measurement, 4, 1-10.

McGuire, C.H., Solomon, L.M. \& Bashook, P.G. (1973) Handbook of written simulations: their construction and analysis. Chicago: Centre for Educational Development, University of Illnois.

McGuire, C.H., Solomon, L. \& Bashook, P.G. (1976) Construction and use of written simulations. New York: The Psychological Corperation.

Meerling (1981a) Methoden en technieken I. Meppel/Amsterdam: Boom.

Meerling (1981b) Methoden en technieken II. Meppel/Amsterdam: Boom.

Miller, G.E. (1968) The orthopedic training study. Journal of the American Medical Association, 206, 601-606.

Mitchell, S.K. (1979) Interobserver agreement, reliability, and generalizability of data collected in observational studies. Psychological Bulletin. 86, 376-390.

Mokken, R.J. (1970) $A$ theory and procedure for scale analysis. Den Haag: Mouton.

Nerenberg, R.L., Noe, M.J., Juul, D.H. (1978) Prediction of graduate clinical performance ratings from multicomponent medical school examinations. Proceeding of the $17^{h}$ Annual Conference on Research in Medical Education.

Neufeld, V.R. \& Norman, G.R. (1985) Assessing Clinical Competence. New York: Springer Publishing Company.

Newble, D.I., Hoare, J. \& Baxter, A. (1982) Patient Management Problems. Issues of validity. Medical Education, 16, 137-142.

Nold, E.W. \& Freedman, S.W. (1977) An analysis of reader's responses to essays. Research in the Teaching of English, 11, 164-174.

Norcini, J.J. (1987) The answer key as a source of error in examinations for professionals. Joumal of Educational Measurement, 24, 4, 321-331.

Norcini, J.J., Swanson, D.B., Grosso. L.J. \& Webster, G.D. (1983) A comparison of several methods for scoring patient management problems. Proceedings of the $22^{\text {nd }}$ Annual Conference on Assessment in Medical Education, 41-46. 
Norcini, J.J., Swanson, D.B., Grosso, L.J., Shea, J.A. \& Webster, G.D. (1984) A comparison of knowledge, synthesis, and clinical judgement: Multiple-choice questions in the assessment of physician competence. Evaluation of the Health Professions, 7, 485499.

Norcini, J.J., Swanson, D.B., Grosso, L.j. \& Webster, G.D. (1985) Reliability, validity and efficiency of multiple choice question and patient management problem item formats in assessment of clinical competence. Medical Education, 19, 238-247.

Norman, G.R. (1985) Objective measurement of clinical performance. Medical Education, 19, 43-47.

Norman, G.R. \& Feightner, J.W. (1981) A comparison of behavior on simulated patients and patient management problems. Medical Education, 15, 26-32.

Nunnally, J.C. (1967) Psychometric theory. New York: McGraw-Hill Book Company.

Page, E. (1968) Analyzing student essays by computer. International Review of Education, 14, 210-225.

Page, G., Bordage, G., Harasym, p., Bowner, I. \& Swanson, D. (1990) A revision of the Medical Council of Canada's qualifying examination: Pilot-test results. In W. Bender, R.J. Hiemstra, A.J.J.A. Scherpbier \& R.P. Zwierstra (eds.) Teaching and Assessing Clinical Comperence Groningen: Boekwerk Publications, 403-407.

Patience, W. \& Swartz, R. (1987) Essay score reliability: Issues in and methods of reporting GED writing skills test scores.

Pawluk, W., Roberts, R. \& Neufeld, V.R. (1976) Concurrent validity of the Canadian Cetrification Examination in Family Medicine. Proceeding of the $15^{\text {th }}$ Annual Conference on Research in Medical Education.

Petrilla, F.J. (1978) Grades assigned by teachers as biased by teacher experience and student characteristics. Dissenation Abstracts International, 39, 3480.

Piché, G.L., Rubin, D.L., Turner, L.J. \& Michin, M.L. (1978) Effects of non-standard dialect features in writing compositions on teachers' subjective evaluations of students and composition quality. Research in the Teaching of English, 12, 107-118.

Rafoth, B. A. \& Combs, W. (1983) Syntax and persuasion: Does syntactic complexity effect the impact of persuasive writing? Research in the Teaching of English, 17, 153-159.

Rafoth, B.A. \& Rubin, D.L. (1984) The impact of content and mechanics on judgement of writing quality. Written Communication, 1, 4, 446-458.

Rash, G. (1960) Probabilistic models for some inteligence and attainment tests. Copenhagen: The Danish Institue for Educational Research.

Rethans, J. \& Boven, C. van (1987) Simulated patients in general practice: A different look at the consultation. British Medical Joumal, 294, 809-812.

Rethans, J., Leeuwen, Y. van, Drop, R., Vleuten, C. van der \& Sturmans, F. (1990) Competence and performance: two different concepts in the assessment of quality of medical care. Family Practice, 7, 168-174.

Rich, J. (1975) Effect of children's physical attractiveness on teachers' evaluation. Journal of Educational Psychology, 67, 599-609.

Rimildi, H.J.A. (1955) A technique for the study of problem solving. Educational and Psychological Measurement, 15, 450-461.

Rimoldi, H.J.A. (1960) Problem solving as a process. Educational and Psychological Measurement, 20, 449-460.

Rimoldi, H.J.A. (1961) The test of diagnostic skills. Journal of Medical Education, 36, 73 79. 
Rimoldi, H.J.A. (1963) Rationale and applications of the test of diagnostic skills. Journal of Medical Education, 38, 364-368.

Rosen, H. (1969) An investigation of the effects of differentiated writing assignments on the performance in english composition of a selected group of 15/16-year-old pupils. Doctoral dissertation, University of London.

Rosenthal, R. \& Jacobson, L. (1968) Pygmalion in the classroom: Teacher expectation and pupils' intellectual development. New York: Holt, Rinehart \& Winston.

Ross, M. \& Salvia, J. (1975) Attractiveness as a biasing factor in teacher judgements. American Journal of Mental Deficiency, 80, 96-98.

Rowe, , P.M. (1967) Order effects in assessment decisions. Journal of Applied Psychology, $51,170-173$.

Samejima, F. (1969) Estimation of latent ability using a response pattern of graded scores. Psychometric Monograph, 17.

Samejima, F. (1972) A general model for free-response data. Psychometric Monograph, 18.

Samejima, F. (1973) Homogeneous case of the continuous response model. Psychometrica, 38, 203-219.

Samejima, F. (1974) Normal Ogive model on the continuous response level in the multi dimensional latent space. Psychological Bulletin, 39, 111-121.

Scannel, D.P. \& Marshall, J.C. (1966) The effect of selected composition errors on grades assigned to essay examinations. American Educational Research Journal, 3, 125130.

Scherpbier, A.J.J.A., Verwijnen, C.M., L'Espoir, N.E.J.C., Metz, J.C.M., Vleuten, C.P.M. van der \& Rossum, H.J.M. van (1988) Het artsexamen in discussie. Bulletin Medisch Onderwijs, 7, 2, 30-35.

Schrout, P.E. \& Fleiss, J.L. (1979) Intraclass correlations: Uses in assessing rater reliability. Psychological Bulletin, 86, 2, 420-428.

Schumacher, C.F. (1973) Validation of the American Board of Internal Medicine written examination: A study of the examination as a measure of achievement in graduate medical education. Annals of Internal Medicine, 78, 131-135.

Schumacher, C.F. (1974) A comparitive study of four methods for scoring an experimental computer-based examination for clinical problem-solving. Proceedings of the $13^{\text {th }}$ Annual Conference on Research in Medical Education, 8-13.

Sedlacek, W.E. \& Nattress, L.W. (1972) A technique for determining the validity of patient management problems. Journal of Medical Education, 47, 263-266.

Sheppard, E.M. (1929) The effect of quality of penmanship on grades. Journal of Educarional Research, 19, 102-105.

Sherif, M., Taub, D. \& Hovland, C. (1958) Assimilation and contrast effects of anchoring stimuli on judgements. Journal of Experimental Psychology, 55, 150-156.

Skakun, E.N. (1978) The dimensionality of linear patient management problems. Proceedings of the $17^{\text {th }}$ Annual Conference on Research in Medical Education, New Orleans, Lousiana, oktober 1978, 63-67.

Skakun, E.N., Taylor, W.C., Wilson, D., Taylor, T., Grace, M. \& Fincham, S.M. (1979) Preliminary investigation of computerized patient management problems in relation to other examinations. Educational and Psychological Measurement, 39, 303-339.

Starch, D. \& Elliott, E.C. (1912) Reliability of the grading of high school work in English. School Review, 20, 442-457. 
Swanson, D.B, Barrows, H.S., Friedman, C.P., Levine, H.G. \& Norman, G.R. (1982) Issues in assessment of clinical competence. Professions Educarion Researcher Notes, $4,2$.

Swanson, D.B., Norcini, J.J. \& Grosso, L.J. (1987) Assessment of clinical competence: written and computer-based simulations. Assessment and Evaluationin Higher Education, 12, 202-246.

Thorndike, R.L. (1982) Applied Psychometrics. Boston: Houghton Mifflin Company.

Vleuten, C.P.M. van der, Luijk, S.J. van \& Beckers, H.J.M. (1989) A written test as an alternative to performance testing. Medical Education, 23, 97-107.

Vleuten, C. van der \& Verwijnen, M. (1990) A system for student assessment. In C. Van der Vleuten \& W. Wijnen (eds.) Problem-based learning: Perspectives from the Maastricht experience. Amsterdam: Thesis.

Vleuten, C. van der \& Wijnen, W. (1990) Problem-based learning: Perspectives from the Maastricht experience. Amsterdam: Thesis.

Wandorff, D.K. \& Essed, G.G.M. (1991) De rol van de docent in het praktisch-klinisch onderwijs: Co-assistentschappen in Zimbabwe en Nederland. Bulletin Medisch Onderwijs, 10, 3, 88-92.

Wang, M.W. \& Stanley, J.C. (1970) Differential weighting: A review of methods and emperical studies. Review of Educational Measurement, 40, 5, 663-705.

Washington, V. (1982) Racial differences in teacher perception of first and fourth grade pupils on selected characteristics. Journal of Negro Education, 51, 60-72.

Webster, G.D., Shea, J.A., Norcini, J.J., Grosso, L.J. \& Swanson, D.B. (1988) Strategies in comparison of methods for scoring patient management problems: Use of external criteria to validate scores. Evaluation \& the Health Professions, 11, 2, 231-248.

Weed, L.L. (1961) Medical records, medical education and patient care. Cleveland Ohio: Case Western University Press.

Wesdorp, H. (1981) Evaluatietechnieken voor het moedertaalonderwijs. Den Haag: Staatsuitgeverij.

Wexley, K., Yuki, G., Kovacs, S. \& Sanders, R. (1972) Importance of contrast effects in employment interview. Journal of Applied Psychology, 56, 45-48.

Wiggins, J.S. (1973) Personality and prediction: Principles of personality assessment. Reading: Addisson-Wesley Publishing Company.

Williamson, J.W. \& McGuire, G.H. (1968) Consecutive case conference. Journal of Medical Education, 43, 1068-1074.

Wolf, F.M., Allen, N.P., Cassidy, J.T., Maxim, B.R. \& Davis, W.K. (1983) Concurrent and criterion-referenced validity of patient management problems. Proceedings of the 22d Annual Conference on Research in Medical Education, 115-121.

Wolf, F.A., Cassidy, J., Maxim, B. \& Davis, W. (1985) A criterion-referenced approach to measuring medical problem solving. Evaluation of the Health Professions, 8, 223240.

Wright, B.D. \& Stone, M.H. (1979) Best test design: Rash measurement. Chicago: Mesa Press.

Wright, B.D. \& Masters, G.N. (1982) Rating scale analysis: Rash measurement. Chicago: Mesa Press. 


\section{DANKWOORD}

Een proefschrift is zelden of nooit het resultaat van de inspanningen van de schrijver alleen. Het is eerder een resultaat van een vruchtbare samenwerking tussen meerdere personen. De mensen die bij de totstandkoming van dit proefschrift betrokken zijn geweest, wil ik op deze plek dan ook bedanken.

Allereerst mijn co-promotor en begeleider Cees van der Vleuten. Ik ben Cees dankbaar voor de vrijheid die hij mij gaf bij het uitvoeren van het onderzoek en zijn bereidheid om op elk moment van de dag tijd voor mij in te ruimen. Zijn enthousiasme en betrokkenheid werkten zeer motiverend. Ook zijn snelle en deskundige becommentariëring van stukken tekst waardeer ik ten zeerste.

Mijn promotor Wijnand Wijnen wil ik bedanken voor de begeleiding die ik van hem heb mogen ontvangen. Zijn nauwgezet commentaar op de hoofdstukken van dit proefschrift zijn zeer waardevol geweest.

Na ruim twee jaren heb ik mijn AIO-schap bij de vakgroep Onderwijsontwikkeling en Onderwijsresearch beëindigd en ben ik als onderwijskundige aangesteld bij de Technische Universiteit Delft. Het tegelijkertijd afronden van het proefschrift en het werken aan de onderwijsvernieuwing bij de Faculteit der Bouwkunde aan de TU Delft heeft veel van mij maar zeker ook van Cees en Wijnand gevergd. Ik ben beiden dan ook erkentelijk voor het geduld en de steun die zij ook in deze periode aan mij hebben gegeven.

Maarten Verwijnen, Yvonne van Leeuwen, Noël L' Espoir en Harrie Crebolder wil ik bedanken voor de constructie van de casuïstiek en de samenstelling van de beoordelingsmethoden. Zonder hun medische deskundigheid had het onderzoek niet kunnen worden uitgevoerd.

Ron Hoogenboom wil ik bedanken voor zijn adviezen en hulp bij het uitvoeren van statistische analyses. Mijn collega Erik de Graaff bedank ik voor de ondersteuning die hij mij in de afgelopen twee jaren heeft gegeven. Zijn continue belangstelling en motiverende opmerkingen waren inspirerend.

Voorts wil ik prof. dr. M.J. Drop, dr. H.J.M. van Berkel, prof. dr. W.M.G. Jochems, prof. dr. J.C.M. Metz en prof. dr. J.A. Knottnerus bedanken voor hun bereidwilligheid om in de beoordelingscommissie plaats te nemen.

Mijn collega's van de vakgroep Onderwijsontwikkeling en Onderwijsresearch alsmede de leden van het Project Evaluatie van Studieresultaten ben ik dankbaar voor de gezellige en collegiale samenwerking.

Ten slotte wil ik mijn vriendin Myriam bedanken voor de ondersteuning die zij mij in de afgelopen periode heeft gegeven. Het schrijven van het proefschrift is ten koste gegaan van de tijd die wij samen konden doorbrengen. Desondanks heeft zij mij continu aangemoedigd en gemotiveerd. Zonder haar steun en begrip zou de totstandkoming van mijn proefschrift veel moeilijker zijn geweest. 


\section{CURRICULUM VITAE}

Pieter Frijns werd op 23 mei 1965 geboren in 's-Gravenhage. In 1983 behaalde hij zijn Atheneum-B diploma aan het Lodewijk Makeblijde College te Rijswijk. In september van dat jaar startte hij met de studie psychologie aan de Rijksuniversiteit Leiden. In 1986 startte hij tevens met de Eerstegraads Lerarenopleiding Maatschappijleer aan dezelfde universiteit. In maart 1987 slaagde hij voor het doctoraal examen psychologie, met als specialisatie Ontwikkelingspsychologie, en behaalde hij tevens zijn eerstegraads lerarenbevoegdheid. In de periode november 1987 tot april 1990 is hij als AIO werkzaam geweest bij de vakgroep Onderwijsontwikkeling en Onderwijsresearch van de Rijksuniversiteit Limburg. Voor zijn werkzaamheden werd hij ondergebracht bij het Project Evaluatie van Studieresultaten van de Faculteit der Geneeskunde. Sedert april 1990 is hij als universitair docent verbonden aan de Technische Universiteit Delft. 


\section{INSTRUCTIES}

Bijgaand vindt $U$ een aantal casus uit het ochtendspreekuur van een middelgrote huisartspraktijk in de stad.

Bij elke casus is én of meerdere vragen gevoegd. U wordt verzocht zich te verplaatsen in de positie en omstandigheden van de betreffende huisarts en vervolgens elke vraag te beantwoorden. Noteer Uw antwoorden op het bijgevoegde antwoordformulier.

Beantwoord de vragen steeds zo specifiek en nauwkeurig mogelijk en vermijd algemeenheden. Probeer zo volledig mogelijk te zijn.

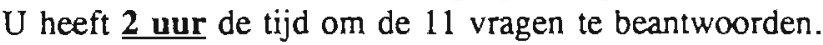

\section{VEEL SUCCES}

\section{Casus mevrouw G.}

De 45-jarige mevr.G. vertelt, dat ze de laatste 2-3 maanden in toenemende mate last van hoofdpijn heeft. De pijn zit vrijwel altijd links-voor in het hoofd en wisselt van intensiteit. Bovendien is het haar opgevallen, dat ze de laatste tijd erg vergeetachtig is en zich moeilijk kan concentreren. Ze maakt zich daar zorgen over.

De medische voorgeschiedenis van mevr. G. vermeldt geen bijzonderheden. Ze komt zelden op het spreekuur en heeft nooit eerder last van hoofdpijn gehad. De huisarts kent haar als een energieke, hartelijke, gelukkig getrouwde huisvrouw en moeder van 3 volwassen kinderen. De gezinsstatus vermeldt geen bijzondere problematiek. Wel is bekend dat de echtgenoot van mevr. G. sinds een half jaar wegens faillissement van het bedrijf waar hij als vrachtwagenchauffeur werkte, werkloos is geworden.

Zowel een psychische als een organische genese van de klachten wordt door de huisarts overwogen. Hij/zij probeert in de anamnese aanwijzingen te vinden voor een nadere differentiatie tussen deze beide gebieden.

VRAAG 1: Welke "gesloten" vragen zijn daarvoor aangewezen? (vermeld de letterlijke tekst van de vragen) 


\section{Casus de heer $\mathbf{M}$.}

De 33-jarige heer M., een alleenstaande onderwijzer van een plaatselijke lagere school, heeft sinds 6 dagen last van diarrhee gepaard gaande met buikpijn en misselijkheid. De buikpijn is zeurend van karakter met af en toe krampen. De diarrhee is waterig met een frequentie van 5-6 maal per dag. De misselijkheid treedt vooral op na het eten. Hij heeft de laatste dagen ook duidelijk minder eetlust. Sinds het begin van de klachten heeft hij een lichtverteerbaar dieet gehouden.

Hij komt nu pas op het spreekuur, omdat er sinds vanmorgen ineens bloed bij de ontlasting zat, waar hij nogal van schrok. Ook is er sprake van enige slijm bijmenging.

Uit de voorgeschiedenis blijkt dat Dhr.M. twee jaar terug een periode met maagklachten doormaakte die goed reageerden op antancida en rust. Voorts is bekend dat hij ca. 10 sigaretten per dag rookt, zelden alcohol gebruikt en geen medicijnen. Voor het overige anamnestisch geen bijzonderheden. De huisarts overweegt de volgende mogelijkheden:

Infectieuze, danwel niet-infectieuze enteritis, 'irritable bowel syndrome' en voedselintolerantie. De laatste twee mogelijkheden mogelijk in combinatie met haemorroïden.

Hij/zij probeert in de anamnese aanwijzingen te vinden voor een nadere differentiatie tussen deze mogelijkheden.

VRAAG 2: Welke "gesloten" vragen zijn daarvoor aangewezen? (vermeld de letterlijke tekst van de vragen)

\section{Casus mevrouw $\mathrm{O}$.}

Mevr. O., een 38-jarige verpleegkundige, maakt zich zorgen over een tweetal klieren, die zij links in de hals sinds een week of vier voelt. De klieren zijn mogelijk iets groter geworden sinds het moment van ontdekking. Ze heeft nergens anders opgezette klieren bemerkt. Ze voelt zich niet ziek maar wel wat vermoeider dan normaal. Ook haar eetlust is wat verminderd en bovendien zou ze de laatste maand $2 \mathrm{~kg}$ afgevallen zijn. Voor het overige levert de anamnese geen nadere bijzonderheden op. Roken: 10 sigaretten p.d.; alcohol: af en toe; medicijnen: geen.

Bij onderzoek van de klieren blijken deze halverwege in de hals gelokaliseerd te zijn, vlak achter de M. sternocleidomastoïdeus. Ze zijn beide ovaal van vorm, ongeveer 1,5 bij 2 $\mathrm{cm}$ groot, vast-elastisch van consistentie, licht onregelmatig van oppervlak en niet drukpijnlijk. Ze zijn noch met elkaar, noch met onder- en/of bovenlaag vergroeid.

De huisarts overweegt een goedaardige lymfadenopathie (primair of secundair) danwel een lymfadenopathie op basis van een maligniteit ("suspecte lymfklier"). Bij het verdere lichamelijke onderzoek tracht hij/zij aanwijzingen te vinden voor een nadere differentiatie, waarbij hij/zij in 't bijzonder let op "suspecte" signalen.

VRAAG 3: Welke verdere bevindingen bij lichamelijk onderzoek pleiten voor danwel ondersteunen de hypothese "suspecte lymfklier"?

(vermeld de bevindingen zo nauwkeurig mogelijk, bv.: asymmetrische kniepees-reflex i.p.v. afwijkende reflexen.) 
Bijlage 1: De casuïstiek

\section{Casus de heer $\mathrm{H}$,}

De heer H., een 37-jarige machinebankwerker, gehuwd, drie jonge kinderen, wordt 's morgens naar de praktijk gebracht, omdat hij onderweg naar zijn werk plotseling duizelig geworden was. Hij had zijn auto aan de kant van de weg gezet en heeft toen gebraakt. Passerende collega's brachten hem naar zijn huisarts.

Dhr. H. is op dat moment goed aanspreekbaar. Hij ziet er duidelijk grauw/bleek uit en bij snel oriënterend lichamelijk onderzoek wordt een polsfrequentie van $100 / \mathrm{min}$. regulair aequaal en een tensie van $120 / 70 \mathrm{mmHg}$ vastgesteld. Aan hart en longen geen afwijkingen. Er worden eveneens geen tekenen van dronkenschap (bijv. alcohol geur uit de mond) geconstateerd.

Bij vervolgens afgenomen nadere anamnese blijkt dat hij de laatste 2-3 maanden al vaker aanvallen van duizeligheid heeft gehad (1-2 maal per 2-3 weken), maar deze waren niet zo heftig van karakter als deze laatste keer. Er is geen sprake van draaisensaties, maar meer een licht gevoel in het hoofd, gepaard gaande met een slap gevoel in de benen, waarbij het hem soms ook eventjes "zwart" voor de ogen wordt. Hij moet dan eventjes gaan zitten, waarna de sensaties meestal binnen een minuut of 5 weer wegtrekken. De aanvallen beginnen altijd acuut, zonder duidelijke aanleiding (zoals bv. snel overeind komen) en er zijn hem, behalve een licht gevoel van misselijkheid, geen andere verschijnselen opgevallen, m.n. geen gehoors- e/o visusstoornissen. Ook is er anamnestisch geen sprake van andere neurologische verschijnselen.

De medische en psychosociale (voor)geschiedenis levert geen specifieke bijzonderheden op. Dhr. H. rookt \pm 25 sigaretten per dag, gebruikt regelmatig alcohol $\left( \pm 1 \frac{1 / 2-2}{}\right.$ l. bier per dag) en gebruikt geen geneesmiddelen. Verder anamnese geen bijzonderheden.

De huisarts probeert vervolgens door middel van verder lichamelijk onderzoek nadere aanknopingspunten omtrent de oorzaak van de klachten te verkrijgen. Hij/zij let daarbij speciaal op de aanwezigheid van specifieke afwijkende onderzoeksbevindingen: signalen, die in een bepaalde richting zouden kunnen wijzen (bijv. een hoge polsfrequentie).

VRAAG 4: Welke signalen zijn bij het verder lichamelijk onderzoek van belang?

(vermeld de bevindingen zo nauwkeurig mogelijk, bv.: asymmetrische kniepees-reflex i.p.v. afwijkende reflexen.) 


\section{Bijlage 1: De casuïstiek}

\section{Casus meneer $\mathbf{S}$.}

Tijdens het ochtendspreekuur om ca. 11.00u wordt er gebeld door Mevr.S. Zij vraagt om een spoedvisite voor haar 73-jarige echtgenoot. Deze zou al een aantal dagen wat "benauwd" zijn, maar zojuist is het plotseling veel erger geworden.

Van dhr. S. is bekend dat hij drie jaar geleden een klein myocardinfarct doormaakte, waaraan hij lichte decompensatieverschijnselen heeft overgehouden. Hij gebruikt daarvoor het diureticum Moduretic ${ }^{R}$ (per tab.: $5 \mathrm{mg}$ amiloridechloride en $50 \mathrm{mg}$ hydrochloorthiazide): 1 dd 1 tab. De laatste 5-tal jaren heeft hij regelmatig (2-3 maal per jaar) een acute asthmatische bronchitis gehad, waarvoor hij steeds met antibiotica werd behandeld.

VRAAG 5: Welke specifieke diagnosen zijn op dit moment te overwegen?

VRAAG 6: Welke zijn daarvan de drie meest waarschijnlijke?

\section{Casus de heer $\mathbf{W}$.}

De 48-jarige heer $\mathrm{W}$. komt met de klacht, dat hij de laatste 6 maanden last van pijn in de bovenbuik heeft. Het is een zeurende pijn, die diep in de bovenbuik gelokaliseerd is en die binnendoor uitstraalt naar de rug. De pijn is niet constant aanwezig; soms heeft hij er een aantal dagen achtereen last van, dan weer een aantal dagen helemaal niet. Er is geen duidelijke toename van frequentie of intensiteit. Er is geen duidelijk verband met maaltijden noch andere provocerende factoren. Hij kan ook alle voedsel verdragen, alhoewel het hem wel is opgevallen dat hij na vet eten soms een paar maal dunne brijïge ontlasting heeft. Voor het overige heeft de ontlasting een normaal aspect en is het patroon niet veranderd. De eetlust is wel wat verminderd en hij is in het laatste half jaar ongeveer $8 \mathrm{~kg}$. afgevallen.

Voor de buikpijn is hij de laatste maanden paracetamol gaan gebruiken (ongeveer 6 tab. per week). Sinds hij werkloos is geworden, drie jaar geleden is hij meer alcohol gaan gebruiken: ongeveer 8 pilsjes (pijpjes) per dag. Hij rookt niet. De overige anamnese levert verder geen bijzonderheden op.

Bij lichamelijk onderzoek wordt er, behoudens licht diffuse drukpijn in de gehele bovenbuik, geen afwijkingen gevonden.

VRAAG 7: Welke drie specifieke diagnosen zijn op dit moment de meest waarschijnlijke? 
Bijlage 1: De casuïstiek

\section{Casus mejuffrouw $\mathrm{H}$.}

De 22-jarige mej. H. komt met de klacht, dat ze al vier maanden geen menstruaties meer heeft gehad. Ze vindt het nu toch wel erg lang duren en vraagt zich af of dit wel normaal is. $\mathrm{Ze}$ had al eerder willen komen, maar vergat steeds een afspraak te maken. Ze werkt als leerling-verpleegster in het ziekenhuis en woont nog bij haar ouders thuis. Bij navraag blijkt ze haar eerste menstruatie op 16-jarige leeftijd gekregen te hebben. Sindsdien is de cylcus altijd onregelmatig geweest, variërend van 21-45 dagen met een 3-4 dagen durende menstruatie. Ze heeft nooit last van buikpijn of gespannen borsten. Sinds enkele weken is er sprake van een licht drukkend gevoel in de onderbuik. Ze heeft gedurende het afgelopen jaar geen gemeenschap gehad en ze gebruikt geen anticonceptiepil noch andere medicamenten. Ze heeft een goede eetlust en is het afgelopen jaar niet afgevallen. Het gewicht is $64 \mathrm{~kg}$. bij een lengte van $1.78 \mathrm{~m}$. Bij het algemeen oriënterend lichamelijk onderzoek worden geen bijzondere afwijkingen of aanknopingspunten vastgesteld.

VRAAG 8: Indien in deze fase besloten wordt tot nader lichamelijk onderzoek en aanvullende lab. onderzoek, welk onderzoek is dan aangewezen?

(Noem letterlijk de onderzoekingen en/of bepalingen, bijv. $\mathrm{Hb}, \mathrm{BSE}$ ).

\section{Casus de heer V.}

De Heer V., een 57-jarige makelaar, vertelt dat hij zich de laatste 3-4 maanden in toenemende mate moe en futloos is gaan voelen. Bovendien vindt hij dat hij de laatste maand ook snel kortademig is geworden, m.n. als hij de trap oploopt of (lichte) lichamelijke inspanning verricht.

Bij nadere anamnese blijkt hij tegenwoordig ook makkelijker te slapen als hij enigszins overeind ligt (3 kussens). Verder zijn er geen klachten, m.n. is er geen sprake van nachtelijke kortademigheidsaanvallen, enkeloedeem, nycturie, angina pectoris of hoesten.

De voorgeschiedenis leert, dat hij 10 jaar geieden geopereerd werd vanwege een liesbreuk. Bij keuringen werd wel eens een wat hoge bloeddruk vastgesteld, maar hiervoor is hij nooit behandeld. Hij rookt sinds zijn $18 \mathrm{e}$ jaar ongeveer 1 pakje sigaretten per dag en drinkt gemiddeld 4 glazen alcohol (bier, wijn of jenever) per dag. Hij gebruikt geen medicijnen. De overige medische en psychosociale anamnese levert geen nadere bijzonderheden op.

Bij onderzoek wordt een bloeddruk van 150/105 mmHG. vastgesteld, bij een polsfrequentie van $90 / \mathrm{min}$. regulair, aequaal. Bij palpatie van het hart blijkt de puntstoot 1 vinger buiten de medioclaviculairlijn te liggen. Verder onderzoek van hart en vaten, longen, abdomen is normaal. Dhr. V. weegt $80 \mathrm{~kg}$. bij een lengte van $1.78 \mathrm{~m}$.

Welk beleid is in deze fase aangewezen ten aanzien van?:

VRAAG 9: Nadere diagnostiek

VRAAG 10: Medicatie

VRAAG 11: Adviezen aan patiënt

(Beschrijf steeds zo specifiek mogelijk) 
Bijlage 2: Een voorbeeld van elke beoordelingsmethode

VRIJE OORDEEL

VRAAG 2

(Maximaal 100 punten)

KORTE ANTWOORDSLEUTEL

VRAAG 2

De antwoordcategorieën lopen van A t/m G.

A. CHRONOLOGIE (100)

B. SETTING (=OMSTANDIGHEDEN WAARONDER KLACHTEN OPTREDEN) (200)

* Mensen in directe omgeving met klachten (90)

* In buitenland geweest (60)

* Stress (50)

C. FACTOREN DIE VOLGENS PATIENT VAN INVLOED ZIJN OP DE KLACHT (200)

* Genuttigd voedsel

D. BEGELEIDENDE LICHAMELIJKE EN/OF PSYCHISCHE VERSCHIJNSELEN (200)

E. ONTLASTING-/DEFAECATIEPATROON (200)

* Voorafgaand aan huidige klacht (100)

* Tijdens de klachtenperiode (100)

F. ALLERGIE (100)

G. FAMILIE ANAMNESE (100) 
Bijlage 2: Een voorbeeld van elke beoordelingsmethode

\section{INGEDIKTE CRITERIALIJST}

VRAAG 2

De antwoordcategorieën lopen van $\mathrm{A} t / \mathrm{m} \mathrm{G}$.

A. CHRONOLOGIE (100)

* Klachtenverloop in de tijd

B. SETTING (= OMSTANDIGHEDEN WAARONDER KLACHTEN OPTREDEN) (200)

* Mensen in directe omgeving met klachten (90)

* In buitenland geweest $(60)$

* Stress (50)

- veel spanningen in/met omgeving

C. FACTOREN DIE VOLGENS PATIENT VAN INVLOED ZIJN OP DE KLACHT (200)

* Genuttigd voedsel

- oorzakelijke relatie tussen genuttigd voedsel en klachten

D. BEGELEIDENDE LICHAMELIJKE EN/OF PSYCHISCHE VERSCHIJNSELEN (200)

* Koorts (35)

* Rillingen (20)

* Ziek voelen (20)

* Gewichtsverlies (35)

* Toegenomen moe (35)

* Maagklachten (20)

* Braken (35)

E. ONTLASTING-/DEFAECATIEPATROON (200)

* Voorafgaand aan huidige klachtenperiode (100)

- eerder moeilijke stoelgang (50)

- kleur/consistentie van de ontlasting (50)

* Tijdens de klachtenperiode (100)

- bloed bij ontlasting (50)

- geur van de ontlasting (30)

- pijn bij defaecatie (20)

F. ALLERGIE (100)

* Voedselintolerantie (60)

* Andere allergische klachten (40)

G. FAMILIE ANAMNESE (100)

* In familie ziektes aan spijsverteringsorganen (65)

* Allergie in familie (35) 
Bijlage 2: Een voorbeeld van elke beoordelingsmethode

\section{UITGEBREIDE CRITERIALIJST}

VRAAG 2

De antwoordcategorieën lopen van $A t / m G$.

A. CHRONOLOGIE (100)

* Klachrenverloop in de tijd

- begin klachten

. geleidelijk

. plotseling

- verloop gedurende de dag

. 's nachts ook klachten

B. SETTING (= OMSTANDIGHEDEN WAARONDER KLACHTEN OPTREDEN) (200)

* Mensen in (directe) omgeving met klachten (90)

- (meer) mensen in omgeving en/of familie met diarree en/of misselijkheid/dergelijke klachten/verschijnselen/symptomen

- zieke kinderen op school met dezelfde verschijnselen/ klachten/symptomen

* In buitenland geweest (60)

- voor klachten op vakantie/in de tropen/in zuidelijk land/buitenland geweest

* Stress (50)

- veel spanningen in/met omgeving/gebeurtenissen die een grote indruk hebben gemaakt/stresserende factoren

. thuis/in omgeving

. op het werk

C. FACTOREN DIE VOLGENS PATIENT VAN INVLOED ZIJN OP DE KLACHT (200)

* Genurigd voedsel

- oorzakelijke relatie tussen genuttigd voedsel en klachten (100)

. wat ( 6 a 7 dagen/week geleden) gegeten

. (6 a 7 dagen/week geleden) anders dan normaal gegeten

. (6 a 7 dagen/week geleden) iets gegeten dat nog nooit eerder gegeten heeft/ voor het eerst gegeten

. bedorven voedsel/voedsel dat al langer stond/iets

verkeerds gegeten

. (6 a 7 dagen/week geleden) buitenshuis gegeten

. (6 a 7 dagen/week geleden) iets gegeten waar al eerder klachten over heeft gehad/slechter kan verdragen

- invloed lichtverteerbaar dieet (50)

- wat wordt nu nog verdragen (50) 
Bijlage 2: Een voorbeeld van elke beoordelingsmethode

D. BEGELEIDENDE LICHAMELIJKE EN/OF PSYCHISCHE VERSCIMUNSELEN (200)

* Koorts (gehad) (35)

* Rillingen (20)

* Ziek voelen/algemeen malaise gevoel (20)

* (De laatste tijd/week/dagen) afgevallen/gewichtsverlies (35)

* Braken (35)

* (De laatste tijd/week/dagen) toegenomen moe (35)

* (De laatste tijd/week/dagen) maagklachten gehad (20)

E. ONTLASTING-/DEFAECATIEPATROON (200)

* Voorafgaand aan de huidige klachtenperiode (100)

- Eerder moeilijke stoelgang: (50)

- (vaker/eerder) perioden met moeilijke stoelgang/ obstipatie/constipatie/harde ontlasting

- (vaker/eerder) perioden met (dunne) diarree/opvallend veel diarree per stoeigang/deze verschijnselen

- (altijd/vaker) veel geperst bij defecatie/ontlasting

- (vaak/regelmatig/ooit) last van winderigheid/buikkrampen

. (vaker/eerder/ooit) pijn bij/na ontlasting/defaecatie/ stoelgang

. (vroeger/eerst) geen klachten/regelmatige stoelgang

- Kleur/consistentie van de ontlasting (50)

. (vaker/eerder) bloed en/of slijmbijmenging/deze verschijnselen

. (vaker/eerder/ooit) kleurverandering ontlasting

. (wel eens/ooit) groene ontlasting

. (wel eens/ooit) pikzwarte ontlasting

. (wel eens/ooit) pus bij ontlasting

- (wel eens/ooit) gele/witte ontlasting die slecht/ moeilijk doorspoelt

. (wel eens/ooit) witte vlokjes bij ontlasting . (wel eens/ooit) wit schuimende ontlasting

* Tijdens de klachtenperiode (100)

- bloed bij ontlasting (50)

. donkerrood of hel/fel//icht rood bloed

. bloedspoortje op toilet-/w.c.-papier

. hoeveelheid

- geur van de ontlasting (30)

. stinkt/ruikt de ontlasting vreemd/typisch

sterk

scherp

zuur

- pijn bij defaecatie/ontlasting (20)

. bij/aan/rond anus

. in de buik 
Bijlage 2: Een voorbeeld van elke beoordelingsmethode

F. ALLERGIE (100)

* Voedselintolerantie (60)

- vaste relatie genuttigd voedsel/eten met diarree

- (bekend met/eerder/ooit) voedsel dat niet verdragen wordt/alles kunnen eten

- (bekend met/wel eens/ooit/eerder) huidaandoeningen/ jeuk/huiduitslag na het eten van bepaald voedsel

* Andere allergisch klachsen/otopische constitutie (40)

- allergisch asthma

- hooikoorts

G. FAMILIE ANAMNESE (100)

* In familie ziektes aan spijsverteringsorganen (65)

- M./ziekte van Crohn

- colitis ulcerosa

* Allergie/atopische constitutie in familie (35)

- voedsel-allergie

. coeliakie/glutengevoelige spruw

. koemelk allergie

- allergisch asthma

- hooikoorts

STUDENT:

BEOOPDEINAR:

\section{SCORE-FORMULIER}

GRAN

TOTAAI

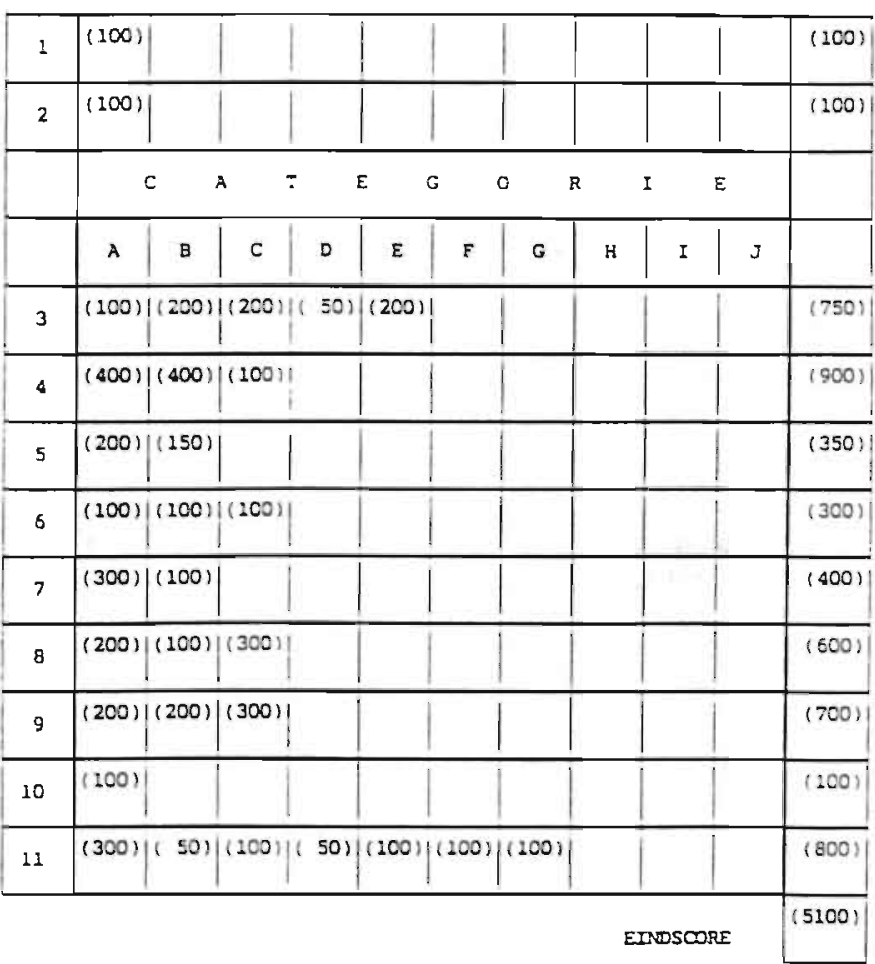


Bijlage 3: De vragenlijst

1. Hoeveel tijd heeft het nakijken van de vragen $U$ in totaliteit gekost?
(1) 0-6 uur
(2) 6-12 uur
(3) 12-18 uur
(4) meer dan 18 uur

2. Verschilde de benodigde tijd per opgave?
(1) ja
(2) nee

3. Schoot Uw inzicht bij het beoordelenvan de antwoorden wel eens tekort?

bij het vrije oordeel
(1) zelden/nooit
(2) soms
(3) regelmatig
(4) vaak
(5) altijd

bij de korte antwoordsleutel
(1) zelden/nooit
(2) soms
(3) regelmatig
(4) vaak
(5) altijd

bij de ingedikte criteria-lijst
(1) zelden/nooit
(2) soms
(3) regelmatig
(4) vaak
(5) altijd

bij de uitgebreide criteria-lijst
(1) zelden/nooit
(2) soms
(3) regelmatig
(4) vaak
(5) altijd

4. Welk correctie-voorschrift vindt U het prettigst?
het vrije oordeel
(1) $\mathrm{ja}$
(2) nee
de geschreven antwoordsleutel
(1) ja
(2) nee
de ingedikte criteria-lijst
(1) ja
(2) nee
de uitgebreide criteria-lijst
(1) ja
(2) nee

5. Hoe vindt $\mathrm{U}$ de gedetailleerdheid van de verschillende correctie-voorschriften?
het vrije oordeel:
(1) te weinig
(2) voldoende
(3) te veel 
Bijlage 3: De vragenlijst

de geschreven antwoordsleutel:
(1) te weinig
(2) voldoende
(3) te veel

de ingedikte criteria-lijst:

(I) te weinig

(2) voldoende

(3) te veel

de uitgebreide criteria-lijst:
(1) te weinig
(2) voldoende
(3) te veel

6. Bent $U$ op bepaalde plaatsen en/of bepaalde gevallen van de instructie afgeweken?
(1) ja
(2) nee

7. Voelde $U$ soms de behoefte om van de instructie af te wijken, maar deed U dit omwille van het onderzoek niet?
(1) ja
(2) nee

8. Met welk correctie-voorschrift kan naar Uw mening de prestatie van de student het meest adequaat worden beoordeeld?

(1) het vrije oordeel

(2) de geschreven antwoordsleutel

(3) de ingedikte criteria-lijst

(4) de uitgebreide criteria-kijst

9. Nadat U een paar antwoorden van een vraag had nagekeken, raadpleegde U het correctievoorschrift vervolgens
(1) minder
(2) evenveel
(3) meer

10. Hoe zoudt $\mathrm{U}$, in het algemeen, Uzelf als beoordelaar omschrijven?
(1) zeer soepel
(2) soepel
(3) gemiddeld
(4) streng
(5) zeer streng

Heeft U nog opmerkingen/suggesties met betrekking tot (1) de scoringsmethode(n), (2) de casuïstiek, en (3) het onderzoek? 
